\title{
State Formation and Radical \\ Democracy in India
}

State Formation and Radical Democracy in India analyses one of the most important cases of developmental change in the twentieth century, namely, Kerala in southern India, and asks whether insurgency among the marginalized poor can use formal representative democracy to create better life chances. Going back to pre-independence, colonial India, Manali Desai takes a long historical view of Kerala and compares it with the state of West Bengal, which like Kerala has been ruled by leftists but has not experienced the same degree of success in raising equal access to welfare, literacy and basic subsistence. This comparison brings historical state legacies, as well as the role of left party formation and its mode of insertion in civil society to the fore, raising the question of what kinds of parties can effect the most substantive anti-poverty reforms within a vibrant democracy.

This book offers a new, historically based explanation for Kerala's postindependence political and economic direction, drawing on several comparative cases to formulate a substantive theory as to why Kerala has succeeded in spite of the widespread assumption that the Indian state has largely failed. Drawing conclusions that offer a divergence from the prevalent wisdoms in the field, this book will appeal to a wide audience of historians and political scientists, as well as non-governmental activists, policy-makers, and those interested in Asian politics and history.

Manali Desai is Lecturer in the Department of Sociology, University of Kent, UK. 


\author{
Asia's Transformations \\ Edited by Mark Selden \\ Binghamton and Cornell Universities, USA
}

The books in this series explore the political, social, economic and cultural consequences of Asia's transformations in the twentieth and twenty-first centuries. The series emphasizes the tumultuous interplay of local, national, regional and global forces as Asia bids to become the hub of the world economy. While focusing on the contemporary, it also looks back to analyse the antecedents of Asia's contested rise.

This series comprises several strands:

Asia's Transformations aims to address the needs of students and teachers, and the titles will be published in hardback and paperback. Titles include:

\section{Debating Human Rights}

Critical essays from the United States and Asia

Edited by Peter Van Ness

\section{Hong Kong's History}

State and society under colonial rule Edited by Tak-Wing Ngo

\section{Japan's Comfort Women}

Sexual slavery and prostitution during World War II and the US occupation

Yuki Tanaka

Opium, Empire and the Global Political Economy

Carl A. Trocki

\section{Chinese Society}

Change, conflict and resistance

Edited by Elizabeth J. Perry and

Mark Selden
Mao's Children in the New China

Voices from the Red Guard generation Yarong Jiang and David Ashley

\section{Remaking the Chinese State}

Strategies, society and security Edited by Chien-min Chao and Bruce J. Dickson

\section{Korean Society}

Civil society, democracy and the state Edited by Charles K. Armstrong

\section{The Making of Modern Korea} Adrian Buzo

\section{The Resurgence of East Asia}

500,150 and 50 year perspectives

Edited by Giovanni Arrighi,

Takeshi Hamashita and Mark Selden

Chinese Society, second edition Change, conflict and resistance

Edited by Elizabeth J. Perry and Mark Selden 
Ethnicity in Asia

Edited by Colin Mackerras

The Battle for Asia

From decolonization to globalization

Mark T. Berger

State and Society in 21st Century China

Edited by Peter Hays Gries and

Stanley Rosen

\section{Japan's Quiet Transformation}

Social change and civil society in the

21 st century

Jeff Kingston

\section{Confronting the Bush Doctrine}

Critical views from the Asia-Pacific

Edited by Mel Gurtov and Peter Van Ness

\section{China in War and Revolution,}

1895-1949

Peter Zarrow

The Future of US-Korean Relations

The imbalance of power

Edited by John Feffer

\section{Working in China}

Ethnographies of labor and workplace transformations

Edited by Ching Kwan Lee

Korean Society, second edition

Civil society, democracy and the state

Edited by Charles K. Armstrong

\section{Asia's Great Cities}

Each volume aims to capture the heartbeat of the contemporary city from multiple perspectives emblematic of the author's own deep familiarity with the distinctive faces of the city, its history, society, culture, politics and economics, and its evolving position in national, regional and global frameworks. While most volumes emphasize urban developments since the Second World War, some pay close attention to the legacy of the longue durée in shaping the contemporary. Thematic and comparative volumes address such themes as urbanization, economic and financial linkages, architecture and space, wealth and power, gendered relationships, planning and anarchy, and ethnographies in national and regional perspective. Titles include:

\section{Bangkok}

Place, practice and representation

Marc Askew

\section{Beijing in the Modern World}

David Strand and Madeline Yue Dong

Shanghai

Global city

Jeff Wasserstrom

Hong Kong

Global city

Stephen Chiu and Tai-Lok Lui

\section{Representing Calcutta}

Modernity, nationalism and the colonial uncanny

Swati Chattopadhyay

\section{Singapore}

Wealth, power and the culture of control

Carl A. Trocki 
Asia.com is a series which focuses on the ways in which new information and communication technologies are influencing politics, society and culture in Asia. Titles include:

Japanese Cybercultures

Edited by Mark McLelland and

Nanette Gottlieb

Asia.com

Asia encounters the Internet

Edited by K. C. Ho, Randolph Kluver

and Kenneth C. C. Yang

\author{
The Internet in Indonesia's New \\ Democracy \\ David T. Hill and Krishna Sen \\ Chinese Cyberspaces \\ Technological changes and political \\ effects \\ Edited by Jens Damm and \\ Simona Thomas
}

Literature and Society is a series that seeks to demonstrate the ways in which Asian Literature is influenced by the politics, society and culture in which it is produced. Titles include:

The Body in Postwar Japanese Fiction
Edited by Douglas N. Slaymaker
Chinese Women Writers and the Feminist Imagination, 1905-1948

Haiping Yan

Routledge Studies in Asia's Transformations is a forum for innovative new research intended for a high-level specialist readership, and the titles will be available in hardback only. Titles include:

1 The American Occupation of Japan and Okinawa*

Literature and memory

Michael Molasky

2 Koreans in Japan*

Critical voices from the margin

Edited by Sonia Ryang

3 Internationalizing the Pacific The United States, Japan and the Institute of Pacific Relations in war and peace, 1919-1945

Tomoko Akami

4 Imperialism in South East Asia A fleeting, passing phase Nicholas Tarling
5 Chinese Media, Global Contexts Edited by Chin-Chuan Lee

6 Remaking Citizenship in Hong Kong Community, nation and the global city Edited by Agnes S. Ku and Ngai Pun

7 Japanese Industrial Governance Protectionism and the licensing state Yul Sohn

8 Developmental Dilemmas Land reform and institutional change in China

Edited by Peter Ho

9 Genders, Transgenders and Sexualities in Japan Edited by Mark McLelland and Romit Dasgupta 
10 Fertility, Family Planning and Population Policy in China

Edited by Dudley L. Poston, Che-Fu Lee, Chiung-Fang Chang,

Sherry L. McKibben and

Carol S. Walther

\section{Japanese Diasporas}

Unsung pasts, conflicting presents and uncertain futures

Edited by Nobuko Adachi

\section{How China Works}

Perspectives on the twentieth-century industrial workplace

Edited by Jacob Eyferth

13 Remolding and Resistance among Writers of the Chinese Prison

Camp

Disciplined and published

Edited by Philip F. Williams and

Yenna $W u$

* Now available in paperback.
14 Popular Culture, Globalization and Japan

Edited by Matthew Allen and

Rumi Sakamoto

15 medi@sia

Global media/tion in and out of context

Edited by Todd Joseph, Miles Holden and Timothy J. Scrase

16 Vientiane

Transformations of a Lao landscape Marc Askew, William S. Logan and

Colin Long

17 State Formation and Radical Democracy in India Manali Desai

Critical Asian Scholarship is a series intended to showcase the most important individual contributions to scholarship in Asian Studies. Each of the volumes presents a leading Asian scholar addressing themes that are central to his or her most significant and lasting contribution to Asian studies. The series is committed to the rich variety of research and writing on Asia, and is not restricted to any particular discipline, theoretical approach or geographical expertise.

\section{Southeast Asia}

A testament

George McT. Kahin

Women and the Family in Chinese

History

Patricia Buckley Ebrey

\section{China Unbound}

Evolving perspectives on the Chinese past

Paul A. Cohen

\author{
China's Past, China's Future \\ Energy, food, environment \\ Vaclav Smil
}

The Chinese State in Ming Society

Timothy Brook 



\section{State Formation and \\ Radical Democracy in India}

Manali Desai

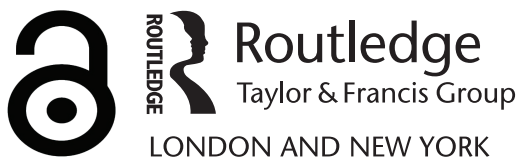


First published 2007 by Routledge

Published 2017 by Routledge

2 Park Square, Milton Park, Abingdon, Oxon OX14 4RN

711 Third Avenue, New York, NY 10017, USA

Routledge is an imprint of the Taylor \& Francis Group, an informa business

Copyright (C) 2007 Manali Desai

Typeset in Times by

Rosemount Typing Services, Auldgirth, Dumfriesshire

The Open Access version of this book, available at www.tandfebooks.com, has been made available under a Creative Commons Attribution-Non Commercial-No Derivatives 4.0 license.

British Library Cataloguing in Publication Data

A catalogue record for this book is available from the British Library

Library of Congress Cataloging in Publication Data

Desai, Manali, 1966-

State formation and radical democracy in India / by Manali Desai.

p. cm.

Includes bibliographical references and index.

ISBN 0-415-40769-9 (hardback : alk. paper) 1. Social change-India. 2. India-Politics and government. 3. Kerala (India)-Social policy. 4. West

Bengal (India)-Social policy. I. Title.

HN690.Z4D47 2006

$320.95409^{\prime} 045-\mathrm{dc} 22$

2006016086

ISBN13: 978-0-415-40769-4 (hbk) 


\section{Contents}

List of tables

Acknowledgements

$\mathrm{x}$

$\mathrm{xi}$

1 Old legacies, new protests: welfare and left rule in democratic India

2 The social bases of rule and rebellion: colonial Kerala and Bengal, 1792-1930

3 State formation and social movements: colonial Kerala and Bengal compared, 1865-1930

4 Political practices and left ascendancy in Kerala, 1920-47 68

5 Structure, practices and weak left hegemony in

Bengal, 1925-47

6 Insurgent and electoral logics in policy regimes:

Kerala and Bengal compared, 1947 to the present

Afterword

Notes

Bibliography

166

Index 


\section{List of tables}

1.1 Select indicators of poverty: Kerala, West Bengal, and all India, 1990s

1.2 Capabilities and functionings, Kerala and Bengal compared, 1991-2001

2.1 Crops and area under cultivation in Travancore, 1920-30

2.2 Distribution of agricultural population in Travancore, Cochin and Malabar: 1901-31 (per 100)

2.3 Rates of proletarianization by state, and the 'proletarianization index', 1911-51

2.4 Proletarianization rate in British India between 1911 and 1951

2.5 Comparative agrarian structures in colonial Bengal and Kerala, 1931

3.1 Percentage of gross expenditure on education to total expenditure of the Travancore state, 1874-1945

3.2 Comparison of growth in state expenditures on education across British Indian and princely states, 1879-1942

3.3 Kerala and India: death rates, 1931-2005 (per 1,000) 59

3.4 All-India comparisons in literacy rates, 1931

3.5 Growth of literacy in Kerala, 1901-2001 60

3.6 Progress of literacy in Baroda state, 1901-31 61

6.1 Trends in Kerala's literacy rate by district, 1961 and $1971 \quad 133$

6.2 Percentage of literates to total population:

Kerala and Bengal, 1901-91 


\section{Acknowledgements}

In the course of writing this book I have encountered debts too numerous to mention. I would like first and foremost to thank my adviser, Maurice Zeitlin, who has been a formative mentor and intellectual guide. This book is dedicated in part to his passion for making academic enquiry about all the things that really matter. I have benefited along the way from discussions with Ronald Herring, Patrick Heller, Bill Roy, Jack Goldstone, William Sewell, Dylan Riley, Dolores Trevizo, Chris Ehrick, Ellen Reese, Eleanor Townsley, and other faculty members at Mount Holyoke College, University of California-Riverside, and the University of Reading, among many, many others. I would also like to thank especially the faculty and students in the Contentious Politics group, who met between 1996 and 1998 at Stanford University's Center for the Advanced Study of Behavioral Sciences. My tenure at the Center as Mellon Graduate Fellow was a most stimulating intellectual experience, and my debts to many there will be quite evident in this book. I also wish to thank the staff at the Centre for Development Studies, Thiruvananthapuram, National Archives of India, Nehru Memorial Library, New Delhi, the British Library and India Office Library, London. A special word of thanks to K.T. Rammohan, Bhaskar and other graduate students at CDS for their warm friendship and many evenings of food and talk. I particularly wish to acknowledge K.T. Rammohan's help with important parts of this research. Thanks also to K. Gopalankutty for some materials. Research for this book was made possible by funding from the International Studies Overseas Program (UCLA), a Dissertation Year Fellowship (UCLA), Mellon Dissertation Fellowship (Center for Social Theory and Comparative History), Faculty Grant (Mount Holyoke College) and Academic Senate Grant (UC-Riverside).

Material in Chapter 2, 3, 4 and 5 has been reproduced with permission of the publishers from the following articles: 'Party Formation, Political Power, and the Capacity for Reform', Social Forces, 82 (4), (C) 2004 by the University of North Carolina Press; 'The Relative Autonomy of Party Practices: A Counterfactual Analysis of Left Party Ascendancy in Kerala, India, 1934-1940', American Journal of Sociology, 108 (3), (C) 2002 by The University of Chicago Press; 'Indirect British Rule, State Formation, and Welfarism in Kerala, India, 1860-1957', Social Science History, 29 (3), pp. 457-88, C 2005 Social Science History Association. All rights reserved. 
This book is dedicated to my parents and sister who have waited patiently; Lucia, friend and mentor; and Kautsky, my labrador companion, who has been rather more impatient.

The book is in memory of the courageous women and men of Kerala who dared not only to dream but to carry their dream forward. We can only hope that in the present zeitgeist we do not lose sight of how much was won. 


\section{Old legacies, new protests \\ Welfare and left rule in democratic India}

\section{Introduction}

Democracy is the new politics of this century, polyvalent, but indispensable as rhetoric and form. Yet the age-old question of the relationship between formal, representative democracy and substantive democracy, or in Amartya Sen's now famous terminology, 'capabilities and entitlements', ${ }^{1}$ remains stubbornly obscure, if never more relevant. The neo-liberal state and formal democracy are increasingly taking isomorphic forms, diffusing across the globe as part of the 'ideal' state. In this context, the question of how different forms of citizenship, including popular protest, can make substantive changes in the life chances of the poor remains pressing. Put another way, the question is: under what conditions can various 'subaltern' classes successfully use formal, representative democracy to achieve basic and crucial freedoms and life-saving entitlements, whether it is land, food, education, medicine, health care or minimum wages? Can popular movements and insurgent associations undermine persistent inequalities from within the norms and practices of formal democracy? ${ }^{2}$ Undoubtedly, these questions require us to ask whether formal democracies can accommodate fruitful democratic struggles - in support of broad popular interests within a democracy.

Contemporary discussions of globalization have probed the forms of resistance that might challenge its hierarchies and distortions. However, in privileging transnational contention, many such discussions elide the specific historical experiences of different societies, and how they influence local struggles. The result in such cases is a discussion abstracted from the challenges that earlier social movements faced, their specific successes and failures, that powerfully frame contemporary struggles. The present, then, forms the entrypoint of this book as it asks about one sub-section of the global disillusionment with the limits of poverty alleviation strategies - namely, why did anti-colonial party-led movements, and later governments, despite the strong promise of redistribution and justice attached to these movements, reach an impasse in delivering substantive democracy or, in Sen's terms, basic freedoms, capabilities and entitlements?

To address this question, this book takes up a comparative examination of a nominally successful case, an 'anomaly' in the Weberian sense of defying the 


\section{Welfare and left rule in democratic India}

norm - namely, the state of Kerala in southern India. This region of India is one of the most closely examined cases of developmental change in the twentieth century, indeed, perhaps the most widely acclaimed 'model' of successful development ${ }^{3}$ other than the East Asian 'tigers'. ${ }^{4}$ Kerala's substantial gains in reducing poverty, at least until the early 1990s, has made it a crucial case for development studies scholars, but its significance for understanding the question of the general failure of post-colonial states has not been adequately investigated. Even today, Kerala's trajectory is of great interest as the debate over the capacity of neo-liberal policies to eradicate poverty continues to rage. As Kerala's earlier solutions to reducing poverty have run into trouble, and the left seeks a selfrenewal, the political possibilities ahead are being debated furiously. Can democratic popular protest create representative organizations and push states to provide basic entitlements, capabilities and functionings to the poorest as was at least once attempted in Kerala? Or has this model run out of steam in Kerala, thus signalling trouble for it in other locales? If so, what are its implications for the democratic route to poverty reduction? Are parties relevant actors anymore? Can social movements make substantial strides in increasing substantive democracy without participating in the sphere of formal democracy? These questions cannot be answered in the abstract; it is necessary to grapple with real experiences, triumphs and failures, and make sense of them. Answers must also be sought in the past.

Those who have followed Kerala's trajectory are familiar with the large advances in literacy, health-related indices of welfare such as mortality rates, land redistribution, economic justice through minimum wages and social security, and not least the demographic breakthroughs that resembled European transitions from the late nineteenth to the early twentieth century. While the role of the state in East Asia has been examined in great depth, in India it is often assumed that the state has largely failed. But in Kerala, each achievement was the product of state policy, whether in the colonial or post-independence era. Indeed, long historical continuity in the state's role in implementing 'welfare from above' in the colonial and the post-colonial eras is itself quite stunning, and deserves sustained treatment. It will allow us to better understand both why the postcolonial state (and regional states) in India have failed to approach the levels of Kerala's achievements, and whether Kerala's own achievements and present dilemmas are a direct product of state strategies dating back to the colonial era.

The period between 1957, when the communists first came to power, and the contemporary period has been the topic of a vast industry of Kerala studies. Kerala has been approvingly cited by left radicals and UN policy-makers alike, each group making sense of Kerala's trajectory through its own specific lens. But the flurry of praise for Kerala's record that emerged by the 1980s flattened critical debate and historical nuance into simple narratives that were repeatedly invoked. Not least was the unfortunate term 'Kerala Model', which appeared to present a utopianized vision of redistributive strategies, counterposed to 'growth-oriented strategies'. This in turn gave rise to a large number of studies stimulated by 
admiration for Kerala's record, which provided little idea of how Kerala achieved comparable gains while no other region of India, not even left-ruled West Bengal, could manage the same. Indeed, no single work addressed the question, paraphrasing Weber, how did Kerala become so and not any other way? One can easily conclude that there has been a near mythologization of Kerala in the development literature. There are a number of important exceptions, of course: these include Peter Evans' Embedded Autonomy (1995), Patrick Heller's The Labor of Development (1999), and Thomas Isaac and Richard Franke's Local Democracy and Development (2000), all of which have addressed the relationship between democracy and development in Kerala in the contemporary period, centring their attention on left policies and the making of these policies.

Where this book departs from these aforementioned studies is in going beyond a focus on the rise and rule of communists in the state, towards a more disaggregated as well as comparative analysis of the long twentieth century in Kerala. It connects events that are often treated separately - colonial penetration, decolonization, and post-colonial rule. Together, this theoretical treatment addresses the question of what is politically possible in post-colonial contexts, placing a great deal of emphasis on the emergence and effects of political practices within given structural constraints. Here, the question is how modes of colonial state rule and state formation affected politics, the character of civil society, and the effects these two factors had upon emergent social movements. Disentangling these is not an easy task, and undoubtedly much more could be written about each of these issues. The book does not attempt to be comprehensive in its coverage of each period; rather, its purpose is to pose some analytical questions that may help to think through a number of problems of postcolonial societies.

The book highlights a comparative question that has long been neglected in the literature, namely, why have successive left governments of West Bengal, where the same left party (the Communist Party of India (Marxist) - CPI-M) has ruled consistently, not achieved the same demographic advances, standards of living for its workers and agricultural labourers, and improvements in public health, to name a few policy areas. In posing this question at the heart of its analysis, the book's innovation is to historicize and concretely specify the role of the left in Kerala's development trajectory. But it is equally important to ask whether the left in either Kerala or Bengal could have done more than it did; to what extent were the limitations of the left largely externally driven; for example, did colonial repression drive a particular type of leftist mobilizing strategy? In the postindependence period, did the quasi-federal system limit what the left could strive for either financially or programmatically, and to what extent were its limits ideological or programmatic? In particular, were these limitations a product of a particular kind of leadership, a failure to evaluate the political possibilities of the time (during and immediately after decolonization), or more generally a reflection of the failure of communism globally? Although the latter point has been repeatedly invoked in criticisms of the left in India, it is crucial for us to 
retain our focus on how these ideological-programmatic principles met conditions on the ground, and were translated into actual practices. Hence the focus of this book on political practices. In addition, apart from the comparative focus of the book, the long historical period of the late nineteenth and early twentieth centuries is necessary in order to ascertain the level of 'autonomy' of the left. This is possible only, as this book argues, if we cut across the sacred divide of 1947, the year in which India won independence from British rule, and link pre-independence political structures and politics with post-colonial ones.

Why focus so closely on the left? After all, one may argue that there are very few traditional left parties that hold power in any part of the world, and their historical relevance may be in serious question. It is important to note that despite the nomenclature of communist party, the parliamentary left in India is Stalinist in rhetoric, but ever-flexible (some say too flexible) in politics. To understand the parties of the left one has to examine what they do rather than what they say. Their own practices have determined their electoral significance, however regionally limited (although in 2004 they rejected a place in the power-holding coalition with the Congress Party, and opted to support it from the outside), which has been won through greater resemblance with the Social Democratic Party in Sweden than, say, with the Chinese Communist Party. The left in India has adopted a pragmatic stance on electoral coalitions as well as neo-liberal policies, seeking to attract foreign investment - but its social base and ideological commitments mark it as fundamentally different from the Congress Party, the long-standing centrist mass party in India. An equally significant division is that between the growing realm of non-party affiliated social movements and nongovernmental organizations, and the traditional left constituted by the CPM and CPI to a more limited extent. But because of the absence of these movements from any political coalitions governing or seeking to govern, the CPM in India remains the crucial focus for any study seeking to ask about progressive parties and movements that hold state power.

In summary, the substantive focus of this book is to enquire into the continuities and ruptures in the realm of politics and state formation in Kerala and Bengal, seeking (1) to evaluate the complex legacy that British colonial rule (direct and indirect) created for left-led post-colonial reform, and (2) to understand what difference left-led mobilization and rule made to the respective social regimes in the two cases. Other comparisons, particularly with colonial policy, left-led political struggles and agrarian structures in Maharashtra, Bihar and Andhra Pradesh, are used to 'discipline' the analysis of specific historical sequences within Kerala and Bengal.

\section{Kerala's anti-poverty policy regime}

In 1957 democratically elected communists in Kerala, defying the antidemocratic experiments then prevalent, but equally the development failures in much of the 'third world' in successive decades, forged what Esping-Andersen 
(1990) has called 'politics against markets'. By the 1980s, the far-reaching networks of social security and direct welfare entitlements, relatively high minimum wages, public distribution of food, and widely accessible health-care and literacy programmes had led to a spectacular record of social development in the state, generating widespread attention and praise. ${ }^{5}$ Other paradoxes followed - their repeated victories (and defeats) in a fiercely contested parliamentary democracy, the pro-labour policies, land reforms (that is, a general prioritization of redistribution in a largely capitalist economy ${ }^{6}$ ), and an association with, and leadership of, movements for social reform - which gave the communists a strong reputation as a party of social change.

These interlocked policies constituted what Przeworski (2000) has called a 'policy regime' - a set of policies that all competing and governing parties in successive decades uphold, regardless of their political affiliations. These institutionalized entitlements - which arguably remain a part of the political 'pact' in Kerala, despite many recent transformations in policy - spelled the unprecedented politicization of subordinate classes, and a resulting infusion of politics with radical demands for democratization through what Amartya Sen has called 'capabilities and functionings'. 7 The social security and egalitarian land and wage policies allowed for a demographic breakthrough paralleled only in the first world, an attendant and remarkable growth in 'social development', and a drop in poverty rates. Entitlements became instruments of shifts in social structures, belying the concept of 'poverty alleviation' in the language of the Indian state and multilateral agencies - which provide an image of top-down relief rather than long-term transformation through the deepening of democracy. Policies, to borrow from Esping-Andersen (1990), had class forming effects, and served furthermore to create and cement class alliances.

With the emerging 'pro-market' consensus through the $1980 \mathrm{~s}$, the very same low to moderate economic growth rates that were once seen as no constraint to development came now to be viewed as the problem, and the emphasis on social development increasingly blamed for Kerala's economic malaise. Many scholars and observers began to argue that governmental (leftist) neglect of economic productivity, far too embedded working class radicalism, and a complacent and poor work ethic are the root causes of the problem - and thus the issue circled back to whether the intervention of the left in Kerala has been a more or less misguided enterprise. ${ }^{8}$ In partial answer to this question, this book brackets the notion of communist autonomy, viewing left party rule and reform as part of a longer historical process in which state formation and notions of state welfarism were created and perpetuated by the communists. Thus, while the centrality of communist-led class formation for Kerala's post-independence land and labour reforms is clear, policies regarding the spread of literacy and health care ironically have precedents in its colonial past. As various scholars of the welfare state have pointed out, social policies are often driven by conservative governments (Esping-Anderson 1990). It follows that the political origins of 
welfare policies in Kerala are not entirely divorced from its colonial origins. Ironically, some of these legacies also undoubtedly had democratizing effects.

A comparative glance at West Bengal suggests, on the other hand, that its CPM-led governments have not implemented such far-reaching reforms. Their most significant and widely publicized reforms are Operation Barga (which granted sharecroppers titles to land ${ }^{9}$ ), ceilings on land sizes, support programmes for sharecroppers such as low interest loans, and wage and employment schemes for landless labourers (Dasgupta 1984; Kohli 1989). There is considerable controversy about the extent to which these programmes have succeeded - and some scepticism about the political will that the CPM-led governments have applied towards implementing the reforms (Dasgupta 1984; Kohli 1989; Mallick 1993). Mallick (1993), for instance, argues that Operation Barga has only benefited the more substantial sharecroppers (a 'new middle landed class') that form the basis of electoral support for the CPM. Moreover, statistics show that with insubstantial welfare and poverty alleviation programmes, the social indicators of development such as literacy rates, mortality, life expectancy, etc. are not too different in West Bengal from those in the rest of India, with the exception of the poorest 'Hindi-belt' states of Bihar, Uttar Pradesh and Rajasthan (see Table 1.1).

Tables 1.1 and 1.2 show significant differences between the two states with regard to social development and hence policy regimes, although as can be seen from Table 1.2 Bengal had a higher rate of economic growth than Kerala during the 1990s. However, Kerala's economic growth jumped from a mere 0.5 per cent during the $1980 \mathrm{~s}-1990 \mathrm{~s}$, to an impressive 5.8 per cent. Indeed, more recent discussions of Kerala's economic crisis are beginning to accept that there has been a clear turnaround during the past five to six years (Kannan 2005; Mathew 2005). While the infant mortality rate has decreased in Bengal over the past few decades, the rate of decline has not been particularly high, surpassed even by some of the poorest states such as Bihar and Uttar Pradesh, and richer ones such as Gujarat, none of which are known for their pro-poor policy orientation. The same picture holds for literacy rates - the rates of change are not very different from other parts of India. As Haris Gazdar notes (1992: 194), 'it is striking, indeed, that energetic activism on the agrarian-reforms agenda went alongside a

Table 1.1 Select indicators of poverty: Kerala, West Bengal, and all India, 1990s

\begin{tabular}{lllll}
\hline & $\begin{array}{l}\text { Sen poverty } \\
\text { index }\end{array}$ & $\begin{array}{l}\text { Literacy rates } \\
(\%)\end{array}$ & $\begin{array}{l}\text { Female/male } \\
\text { literacy rate } \\
\text { ratio }\end{array}$ & $\begin{array}{l}\text { Under 5 mortality } \\
\text { per 1,000 }\end{array}$ \\
\hline Kerala & 0.13 & 89 & 0.93 & 40 \\
West Bengal & 0.24 & 51 & 0.75 & 139 \\
All India & 0.18 & 45 & 0.61 & 117 \\
\hline
\end{tabular}

Source: Shariff (1999). 
Table 1.2 Capabilities and functionings, Kerala and Bengal compared, 1991-2001

\begin{tabular}{|c|c|c|}
\hline & Kerala & Bengal \\
\hline Population, 2001 (millions) & 32 & 80 \\
\hline $\begin{array}{l}\text { Growth rate of per capita SDP, } \\
2000-01^{1}(\% \text { per year })\end{array}$ & 5.8 & 6.8 \\
\hline Life expectancy at birth, $2000^{2}$ (in years) & $\begin{array}{l}76 \text { (female) } \\
71 \text { (male) }\end{array}$ & $\begin{array}{l}64 \text { (female) } \\
63 \text { (male) }\end{array}$ \\
\hline Infant mortality rate (per 1,000 live births) & 14 & 51 \\
\hline Death rate, age $0-4,1991^{3}$ (per 1,000$)$ & $\begin{array}{l}4.1 \text { (female) } \\
4.5 \text { (male) }\end{array}$ & $\begin{array}{l}20 \text { (female) } \\
20 \text { (male) }\end{array}$ \\
\hline $\begin{array}{l}\text { Estimated maternal mortality rate, } \\
1987-96^{4} \text { (per } 100,000 \text { live births) }\end{array}$ & negligible & 458 \\
\hline Literacy rate, age 7+, 2001 (\%) & $\begin{array}{l}88 \text { (female) } \\
94 \text { (male) }\end{array}$ & $\begin{array}{l}60 \text { (female) } \\
77 \text { (male) }\end{array}$ \\
\hline
\end{tabular}

Sources: Census of India 2001.

http://www.censusindia.net/results/2001census data index.html)

1 Source: http://www.indiatogether.org/health/infofiles/life.htm

2 Source: http://www.macroscan.com/fet/aug03/fet100803SDP_1.htm. Figures are approximations.

31991 figures taken from Dreze and Sen 1991:Table A3 (appendix).

4 Figures from Bhat 2001: 11.

near total absence of initiative in public policy on other factors that influence well-being'. It is this difference in state capacities, and their historical and political determinants, that is the prime interest of this book.

\section{Central questions of the book}

This book begins with the critical question of the impact of British colonial rule on popular insurgency and its legacies for future regimes in post-colonial Kerala. This is because to some extent state capacities in the direction of popular welfare were also shaped during the colonial era. Thus the relevant historical sequence for this book is between 1860 and the late 1990s. This sequence captures the full effects of British policy on Kerala and its shadow comparison Bengal, especially the peculiarity of nineteenth-century state reforms in the princely states of colonial Kerala (Travancore and Cochin), and the peculiarities of Kerala's social structure, all of which could potentially go a long way towards explaining its anomalous trajectory. In other words, even within Kerala's own historical trajectory there are at least two alternative explanations of its unique outcomes: (1) the princely state policies of the nineteenth century were the first to create Kerala's divergence from the rest of India, and are thus the primary cause of its 'exceptionalism', or (2) communist-led mobilization and governmental policies 
in the pre- and post-independence periods were primarily responsible for its exceptionalism. By and large, scholars who have emphasized Kerala's 'civic associational' traditions or communist party-led mobilization (Heller 1999; Isaac and Franke 2000) in democratizing development tend to ignore the fact that the two princely states of Travancore and Cochin had implemented land, education and health-care reforms during the nineteenth century, leading to Kerala's divergence from India well before the post-independence era. These reforms accompanied the increasing penetration of the state in civil society. Arguably, without these quasi-Bismarckian policies, many aspects of Kerala's development might have looked no different from other directly and indirectly ruled regions of colonial India. The evidence from Bengal appears to support such a view, for, without similar state legacies, communist rule has not produced comparable reductions in poverty.

Yet the evidence from Kerala suggests the crucial importance of communist mobilization, networks and rule in extending and maintaining the state's welfarist orientation. This book's second crucial question, therefore, is: how did the political practices of left movement and party activists between 1934 and the late 1990 s - relative to inherited 'objective' circumstances - affect the formation (and later, potential 'crisis') of a distinctive anti-poverty regime in Kerala? In other words, what effects did the political practices associated with the early and late left in Kerala have on its distinctive regime of anti-poverty welfare, and what new limits did these practices pose on Kerala's political economy? A basic premise of this book is that Kerala's uniqueness has to be understood as a historical confluence of changes and continuities at three levels - state, regime, and government.

\section{Three puzzles}

A focus on Kerala helps us to resolve three crucial comparative puzzles. First, why has its policy regime - weighing more heavily on the side of redistribution rather than accumulation - diverged so significantly from that of the rest of India (whose record has been sluggish on both counts)? It is well known that India's fractious political scene has not produced an appropriate environment for reducing mass poverty. One influential theory characterized the Indian state as 'regulatory (and hence patronage-dispensing) rather than developmental', suggesting that most constraints on growth have been imposed by the politically organized and articulate dominant 'proprietary classes' (Bardhan 1984). This dominance has a strong political lineage in the form of the Congress Party. Like Mexico's PRI (Partido Revolucianario Institutional), the Congress Party in India has dominated the shape of India's democracy and its developmental strategy. The Congress party led the anti-colonial movement against over 200 years of British rule, culminating in India's independence in 1947. From its formation in 1885 by a small group of lawyers and other professionals, the Congress Party had by 1947 grown into a mass organization with branches in even the most remote 
districts and villages. This was owed in no small part to the leadership skills and tactics of Mahatma Gandhi, who took the elite party through its passage to mass movement by, among other things, speaking in the idiom of poor, illiterate peasants. However, despite the tumultuousness of the anti-colonial movement, and the mobilization and radicalization of all sectors of Indian society, it is a salient feature of Indian political life that workers and the lower peasantry have failed to make a dent in patterns of accumulation and distribution. That they have done so in Kerala is of much comparative interest. As most political-economic analyses of post-independence India have concluded, class has been a relatively weak line of conflict when compared with caste, religion or ethnicity. '[C]lass politics has not been and is not likely to become the principal medium for representing India's “weaker sections”, note Rudolph and Rudolph (19687: 20). More recent discussions of Indian politics, social movements and parties echo this earlier view; rather than class it is caste and ethnicity that organizes political protest (Ray and Katzenstein 2004). If so, then why and how, given the enormous caste hierarchy in the region, and the extreme methods of social exclusion - and thus the obvious role of caste in political conflict - did Kerala's often lower caste agrarian and industrial workers come to make class-based claims and effectively stake a share in Kerala's future pattern of accumulation?

Scholars are beginning to turn more closely to a study of the political stalemate created in India by a weak state and contending political interests, not least among the rural elite (Chhibber 2003; Jenkins 1999). First, there is the issue of 'state capacity', which is characterized as weak in the Indian context. The concept of state capacity draws upon the Weberian notion of a rationalized administration, of an insulated bureaucracy, embedded networks between state and society (capital and labour particularly) (Weiss and Hobson 1995). Weakness and strength are of course relative evaluations, and as such have no independent meaning; yet there is an implicit comparison to western, democratic states which have evolved state capacities through democratic struggles against the feudal capture of state institutions. In post-colonial states, this concept is more complicated, as administrative institutions were established as part of colonial rule and as such did not simply mimic the development of western states. In colonial states, and to some extent as a legacy in post-colonial states, the repressive capacity is better developed than its 'infrastructural' capacity. We will need to evaluate why the latter was developed so strongly in Kerala.

The second point of divergence is that of redistributive politics and the push 'from below', which in India has been comparatively quite weak. Several explanations exist to explain this. On the one hand, the Congress Party is itself blamed for its 'class conciliatory', 'non-violent and incremental approach' to glaring questions of class inequality (Frankel 1978; Kohli 1987: 54). Among Marxist and other leftist scholars, Gandhian ideology and strategy has been given a good share of the blame for suppressing popular radicalism within the nationalist movement (e.g. Sarkar 1983). Others have blamed weak left party strategies, that is, the economic determinism and consequent rejections of 
'subaltern' consciousness, which resulted in the failure to tap the radical potential that existed in India. ${ }^{10}$ It is argued that the left's (communists') failings during the anti-colonial movement have carried over into the post-independence era (Chandavarkar 1997; Vanaik 1989). Futile debates over the 'real' character of the Indian state and the Congress Party, it is argued, have allowed the communists to remain weak even when popular discontent against the Congress Party surged.

To understand what share of the blame should be placed at the door of left parties, who undoubtedly had a significant political opening at a crucial moment of modern Indian history, one must ask whether alternative trajectories that might have led to the dominance of subaltern movements within the incipient state were possible at the time. Such an analysis would have to account for the complexity of the 'objective conditions' obtaining in India, and its enormous regional variation, and the potential for radical movements to develop. Thus far, few proponents of the 'weakness of the Indian left' thesis have attempted to ask whether alternative strategies would have necessarily ensured their dominance. Instead, scholars of India's anti-colonial nationalism have displayed a tendency to swing between structuralism and voluntarism. Debates veered between the 1970s 'mode of production' arguments that sought to determine whether the Indian formation was capitalist or some hybrid between pre-capitalism and capitalism, towards a renewed interest in subaltern forms of resistance and fragmented histories. This sometimes compelling body of work focuses beneath the 'radar' of formal politics, avoiding discussion of the outcomes of political contention, and the vast changes that have occurred in the forms of subaltern resistance ranging from those in the formal party sphere, to the more localized and micropolitical.

This book is situated somewhere in the middle of these two bodies of work. It takes up the case of Kerala for in-depth historical exploration to pose the question of why and how its 'exceptionalism' emerged, and whether this trajectory was possible in other regions of India (or the third world). It opens up a distinct anomaly, namely, that left parties generally failed to break ruling class domination in the course of anti-colonial movements (except in the few cases where they led revolutions), but they did succeed in doing so in Kerala. Opening up this question suggests that the suppression of radical possibilities in most postcolonial cases may lie in the nature of colonial rule itself, in part through state repression, and in part through the persuasive force of what Gramsci called a 'passive revolution'. By this term he meant the creation of a vast political revolution which, however, maintained conservative social structures and the dominance of the propertied classes. The passive revolution was in no small part a product of the changes encouraged by the British in Indian political expression and representation. A vast literature has documented the difficulties that radical popular resistance faced within the Indian anti-colonial struggle, defeated partly by strategies of isolation on the part of left leaders, but also because of persistent repression by the British. Furthermore, their encouragement of the channelling of discontentment through the Congress Party (until it grew into a mass movement) 
had the consequence, for a variety of complex reasons to be explored in this book, of co-opting and mopping up radical alternatives to the Congress Party. Seen in this light Kerala is a distinct anomaly, as the communists gained ascendancy within the Congress-led nationalist movement in the region.

A final anomaly that merits explanation is why the rigid and hierarchical caste relations existing in Kerala did not inhibit class formation there, but appear to have done so elsewhere in India (or at least are claimed to have done so (see Moore 1966). One 'structural' explanation holds that the close correspondence between caste and class in Kerala made the outcome of class politics almost inevitable once lower castes began self-organizing (see Jeffrey 1984), but comparative evidence does not reveal such a 'natural' link between lower caste and class movements even where they structurally coincided. Moreover, it can be argued that daily rituals of caste submission and subservience have prevented the growth of modern political consciousness, and bear a good part of the blame for the weakness of class consciousness in India. ${ }^{11}$

The transformation of what one contemporary observer of early twentiethcentury Kerala called a 'madhouse of caste', towards the predominance of classbased protest emerges as a distinct puzzle. Although for a long time the daily practices of segregation and servility prevented collective rebellion among lower castes, new forms of colonial governmentality such as census-based or caste categories encouraged modern associational forms among various castes across India, which in some instances took radical forms. In Kerala, these caste organizations initially discouraged the language and politics of class confrontation, but gradually became radicalized. Indeed, caste radicalization was a crucial precondition and precursor to communist ascendancy in Kerala.

\section{Summary of the argument}

The central part of the book's analysis is to show how the interaction between state legacies and the early phase of the winning of left 'hegemony' in Kerala converged to create its distinctive policy regime, and to evaluate both the achievements and limitations of this regime. I grant state legacies as well as political practices some autonomy, arguing, however, that without the left's political practices, the effects of state legacies upon future regimes would have been lost. This reconstruction puts a large explanatory burden on how left leaders used a variety of political tactics within shifting political circumstances, cobbling together a substantial extension to the prior welfare state once they won power. None of this would have been possible without carefully chosen strategies and tactics; but these did not simply appear from nowhere. They were historical products of prior patterns of caste struggle as well as state formation. This analysis thus points the way to a more nuanced and historically informed analysis of contemporary developmental dilemmas and the role of social movements in the era of globalization. 
The argument of this book rests firmly upon the Gramscian concept of 'hegemony', defined as the moral-political authority to transform society. This hegemony is the product of political strategies and tactics employed by organizations; within a mass anti-colonial movement it involves seizing the opportunity to define the scope of the movement. My argument is that the hegemony of the communists in Kerala was made possible because they formed a left faction of the mainstream nationalist party, also known as the Congress Socialist Party (CSP), during the anti-colonial political struggles of the 1930s and 1940s, thus avoiding isolation as experienced by other communists across British India. They utilized existing repertoires of lower caste struggles, yet organized workers and tenants by effectively expanding their tactics to include land invasions, strikes and public protests. This had the effect of placing the CSP at the heart of the anti-colonial movement in Kerala, a feat not achieved anywhere else in India.

Central to this argument is the claim that these class- and caste-based challenges were integral to left party formation in Kerala, leaving a distinct 'movementist' or insurgent imprint on its identity. The communist party in Kerala was thus born through its insertion in a newly constructed 'civil society', rather than as a secret, underground cell as it was elsewhere in India. This factor was crucial to its later abilities to effect reforms in Kerala's social policies and social structure. Most importantly, the party's association with a range of popular movements and with tactical innovation and associations was key to its hegemonic project, as it made possible multi-class alliances that underpinned its electoral victories, and reduced the salience of caste associations in Kerala's civil society. In turn, this party formation legacy gave social movements a critical role in determining the future of the state's developmental choices.

In giving politics this kind of autonomy, my argument diverges from earlier Marxist and pluralist accounts of party formation and ascendancy (social base and cleavage arguments). Briefly, these theories view parties as reflections of underlying social relations that exist prior to the party. My theory not only places political organizations and practices prior to social relations (that is, views the former as instrumental to the latter (such as class formation)), but it additionally shows how structures exercise important effects in more indirect ways. Thus I will argue in Chapter 4 that the various class and caste configurations that existed in colonial Kerala encouraged, but did not determine, left party formation, and show through comparative evidence that similar social structures elsewhere did not produce the same political organizations.

In probing the specificity of left political strategies in Kerala, a crucial comparative question is obviously to ask why there has not been a comparable parliamentary challenge from left parties in other regions of India, except for the significant case of West Bengal, where communists have held power even longer and more consistently than in Kerala - for an unbroken six terms since the 1960s when they first came to power. They have also instituted far-reaching land tenure reforms, and maintained higher economic growth rates than in Kerala. Yet on 
balance Bengal is weaker on measures of substantive democratic outcomes than Kerala, because - as this book shows - popular contention in the state was relatively weaker and the communist party was less embroiled in popular struggles than in Kerala.

Were these differences merely due to differences in the social base of the communists in the two states? In earlier scholarship on Kerala there was a consensus that 'structural' conditions (conceived mostly as property relations), which determine the combination of interest, incentive and opportunity for collective organization among subordinate groups, could explain much of its radical trajectory. That is, the overwhelming preponderance of sharecroppers and agricultural labourers, as well as Kerala's high proletarianization rates in the midtwentieth century, influenced a left turn in politics. Some scholars such as Herring (1983) and Kannan (1988), while emphasizing the structural preconditions of Kerala's development, gave a strong role in their analysis to the communists' strategies of political struggle in determining its policy complex. ${ }^{12}$ Yet, these studies begged the crucial comparative question of why the communists in Kerala were successful while they were not elsewhere even where similar objective conditions prevailed. The table below shows the differences in political outcomes in cases that ostensibly shared rather similar structural conditions. It is beyond the scope of the book to discuss each outcome in detail, but a brief look at their trajectories in Chapter 2 (and a more in-depth look at Bengal) reveals some interesting differences which highlight the role of political strategy and tactics at crucial historical moments in effecting their ascendancy.

\section{Political outcomes in four regions sharing structural characteristics}

\section{Late colonial}

Bihar

Andhra

Kerala

West Bengal
CSP ascendancy

CSP/CPI ascendancy, insurgency

$\mathrm{CSP} / \mathrm{CPI}$ ascendancy, insurgency

CPI ascendancy, insurgency (weak)
Post-independence

Conservative Congress

Congress/Telugu Desam

$\mathrm{CPM}$ and Congress

$\mathrm{CPM}$

\section{The dilemmas of left parties in a democracy}

A large section of this book is devoted to the practices of Kerala's communists within the nationalist movement, with a view to explaining how and why these practices mattered in subsequent decades. In this sense the question of democracy remains largely irrelevant until Chapter 5. But it looms large in this book because part of the puzzle is that Kerala's communists eventually achieved what they did within a competitive parliamentary democracy. As Kohli (2001) has argued, India's transition to democracy remains a neglected issue in scholarship. 
Although he cites the puzzle of why India has remained democratic under difficult conditions, a large part of the puzzle is also to establish why substantive democracy still remains so weak in a thriving parliamentary democracy. One way of thinking about these two questions together is to ask whether the stability of India's democracy despite underlying difficult conditions is owed to the failure or stalling of substantive democracy, and conversely the counterfactual - whether substantive democracy in India might have been worse off without a firmly established parliamentary system. As the ferment of the formative years of the communist parties and the immediate decades following it attest, violence and instability were an integral part of subordinate class demands for substantive democracy. The Congress-dominated state in many instances had to suppress these demands and the radicalization of the communist parties for stability to prevail in the post-independence Indian democracy.

The question of whether parliamentary democracy forces radical left parties to capitulate and soften their goals has been debated for a long time. As a corpus of work on democracy has shown, the formal freedoms of democracy, such as parliamentary rule, suffrage, and civil rights, were themselves the product of political struggles in which subordinate classes often played a key role (Moore 1966; Rueschemeyer, et al. 1992; Therborn 1977). Yet, ironically, one may argue that these very freedoms have stalled the further expansion of substantive democracy, in part because they have congealed in the form of liberal democracy, a pluralistic form imbricated with unequal social structures, exploitation and 'unfreedom'. In producing consent to this form of representation, liberal democratic institutions suppress alternative possibilities of popular participation, as well as insurgent protest from the working classes and poorer, disempowered groups. Democratic institutions have thus presented socialists with a dilemma, for their close association with the reproduction of capitalism (as they have tended to understand it) has raised serious questions about the possibilities for any meaningful transformation of structures of inequality from within these institutions. Hence 'revolution' was viewed as the only meaningful form of social transformation, of bringing about social democracy. However, there were also splits among socialists about the promise and perils of the 'parliamentary path' ${ }^{13}$ As Przeworski and Sprague (1986: 14) note: 'once established, the new political institutions had to be treated either as the enemy or a potential instrument'. ${ }^{14}$

The adoption of the parliamentary path by Kerala's communists and by the two major communist party formations in India, followed from a brief experiment with the insurrectionary tactic of guerrilla warfare in Andhra Pradesh, in particular, but also in the two other significant bases - Kerala and Bengal. The failures and near collapse of the party (CPI) gave the communists a bracing view of their position in Indian politics - their regional confinement and hence political weakness and the formidable military apparatus of the Indian state. This appears to have brought a large section of the communists to the necessity for 'gradualist' tactics of revolution. To date the communists have not relinquished the language of revolution; however, they have gradually approximated the social democratic parties of Europe in many ways, most importantly by participating in 
parliamentary politics. It is difficult to know what their alternatives were; in part this book seeks to assess this very question. In Kerala, the parliamentary pathway made intuitive sense, for the communists had long been engaged in local governmental institutions such as the Malabar District Board, since at least the 1940s. They had come to excel in the use of liberal democratic institutions, using Kerala's social movements tradition to continually recreate political struggles to deepen the relevance of these democratic institutions. Indeed, in view of the evidence of such local initiatives, any account of Indian democracy that views it as a mere colonial installation is misleading.

One reason why formal democracy may (but does not necessarily) limit real reforms is because the social structures of capitalist societies limit what parties can achieve (Przeworski and Sprague 1986). Left parties cannot push through long-run reforms that will benefit only the working class, theoretically their primary social base, simply because of the algebra of parliamentary elections. No single socialist party has ever won more than 50 per cent of the vote without 'diluting' its base and forging coalitions which make the working classes merely another constituency. ${ }^{15}$ In turn, as Przeworski and Sprague argue, this dilutes socialist political programmes towards populism. Socialist parties risk losing sight of their objective of inching closer to socialism through parliamentary elections and social policy, because the democratic 'rules of the game' necessarily defeat this purpose. This is a provocative claim that will find much resonance in the materials on Kerala and Bengal. In particular, I will argue that the formal rules of democratic electoral competition have skewed the insurgent possibilities as well as the policy priorities of the communists towards winning the next set of elections. This reinforces political conventionality rather than innovation and risk. In Bengal, more so than in Kerala, the formal, parliamentary arena was the primary terrain for party formation and attempts at hegemony in the postindependence era. In both cases, the parties have had to cater to the algebra of elections, leaving revolutionary practice to the side. However, while the challenges to substantial reform witnessed in both cases have confirmed Przeworski and Sprague's argument, it is not for the reasons specified by them. The dualistic rubric of 'reform vs. revolution' is not analytically very helpful. If the communists in Kerala and Bengal had not entered the electoral arena, perhaps they would have been rendered inconsequential; neither state would have seen comparable reductions in poverty under Congress governments even with the pressure of social movements from below.

Furthermore, at a purely demographic level, left parties in countries like India, Brazil, Mexico and South Korea do not face the dilemma posed by the numerical weakness of the working classes, since workers (defined even in the strictest Marxist terms) are still significant in these economies and a crucial base for left parties. At the same time, given that in most of these societies rural constituencies are powerful, an agrarian-industrial alliance is a crucial underpinning for any left hegemonic project. But drawing the pre-capitalist, and combined and uneven logic of agrarian relations into the bourgeois logic of elections poses its own specific problems for the left. Here, the issue of social 'heterogeneity' looms 
large; the 'articulation' of capitalist and pre-capitalist relations, that is, the mutual imbrication of wage labour and bonded, unfree labour, as well as caste, ethnic and tribal relations that criss-cross with one another, produce a dizzying array of fissures that must be delicately negotiated. These render not only a 'semiproletariat' with strong agrarian ties, but also forms of consciousness and action that cannot be understood through the lens of theories of working class action in advanced capitalist contexts. In India, the most common strategy adopted by parties is to utilize a modern concept of caste to create pan-regional solidarities across smaller sub-castes (jatis), and the minutiae of structural divisions which have made caste appeals salient in Indian political life.

Finally, and perhaps centrally as far as this book is concerned, it is important to note that the question of how much a left party can achieve through parliamentary participation is not merely an 'abstract' theoretical issue, however much it may have figured in grand political debates within Marxism. ${ }^{16}$ The answer depends on what it has done to get there, and what it is aiming at by participating in bourgeois politics. Hence the important link between historical practices and their effects on future pathways - a link that runs through the entire book.

\section{The 'relative autonomy' of the political}

In this book I treat parties as congealed practices rather than as institutions, networks or organizations in a formal sense. This does not mean that the other concepts and approaches are flawed; rather, this way of thinking about parties allows us to pay close attention to political practices and not merely the rationally constructed strategies and tactics that parties attempt to implement. In particular, I seek a better understanding of how political practices matter in the "making and unmaking' of salient cleavages through which hegemonies are forged. ${ }^{17}$

The autonomy of parties from social cleavages has been increasingly recognized in political science and political sociology (Chhibber 1999; Keck 1992); yet it has also been recognized that parties bear some relationship to the dominant social cleavages in a society. In earlier liberal ${ }^{18}$ as well as Marxist political sociology, ${ }^{19}$ parties were viewed strictly as representations of social cleavages. This theory and its attendant methodology of producing typologies and correlations were, however, temporally static, leaving out the process by which 'the working class' or any other cleavage such as religion or ethnicity is formed, and its 'interests' articulated.

In eliciting the relatively independent effects of party practices on left party ascendancy and class formation in Kerala, this book treat parties as active agents in the formation of 'cleavages', ${ }^{20}$ and suggests that to some extent they causally precede the political articulation and 'representation' of the latter. Thus it does not assume pre-given social boundaries, or assign interests to these groups or cleavages. However, neither does it suggest that parties form or come to represent cleavages at their will. Their political autonomy is 'relative' to the specific, underlying 'structural' relations in a given society (Przeworski 1985; Stepan- 
Norris and Zeitlin 1989; Zeitlin 1984). ${ }^{21}$ The latter, moreover, provide the very means of generating and inhibiting the potential for movement/party growth. ${ }^{22}$

The political practices by which parties come to gain authoritative and hegemonic representation of social cleavages that they in part help to form have two components which will be developed in the empirical analysis. The first issue is how a party strategizes vis-à-vis the state, that is, the manner in which its leaders and activists recognize existing 'political opportunity structures', and can seize upon them at critical historical moments.

The second issue concerns the strategy forged by parties in 'civil society', an increasingly deployed concept in theories of democratic practice. Rather than assume that civil society is inherently a sphere of solidarity and 'good' associationalism, ${ }^{23}$ or that it is from this domain that democratic impulses inevitably originate, however, I argue that parties and the 'relatively autonomous' sphere of the political constitute a separate realm which plays a crucial role in 'forming' social cleavages and their demands out of the myriad conflicts situated in civil society. In particular, the concept of civil society is of interest for a concept of party hegemony, for a party wins hegemony in part through its strategy in civil society. It must both address itself to prior forms of activism and association in civil society, and galvanize new forms. The crucial link here is that left parties do not gain ascendancy and hegemony merely by representing class interests; they play an important role in defining the terrain of the political, and staking claims to issues that go beyond class, relating to other popular movements. Such parties are more deeply inserted in civil society, and when in power are made accountable to these existing organizations.

\section{Party dominance vs. hegemony}

It is crucial to distinguish between party hegemony and dominance, simply because of the way in which the two terms are often collapsed in the literature. For example, Pempel (1990) has argued that dominance is a sufficient condition for a party to push through its policy agenda. In turn, he defines dominance as follows:

A dominant party must at least gain an electoral plurality, which means dominance in socioeconomic mobilization. It must also enjoy or create a bargaining advantage vis-à-vis other political parties so it remains at the core of any coalitions that are formed. Then, it must remain in office long enough to implement its historical agenda. Finally, while in office it must be able to implement that historical programme and use the instruments of the state so as to isolate its opposition and strengthen its own electoral position. Dominance thus involves an interrelated set of mutually reinforcing processes that have the potential to beget even more dominance.

(Pempel 1990: 16) 
Quite simply, using the concept of party hegemony or hegemonic capacity to describe Kerala's social policies is misleading if we use the term to mean 'dominance'. In this case there is a noticeable lack of 'hegemony' as defined by Pempel because the communists have not remained in power for long enough to 'implement their historical agenda', holding office for almost an equal number of terms as their opposition, and have been unable to use the state to isolate their competitors (the Congress Party). On the other hand, they have been able to remain at the core of coalitions, implement a historical programme, and dominate the mobilization of workers, peasants and sections of the middle classes. This was particularly true of their tenure until the 1980s, after which the communists began to encounter the limits of a class confrontational strategy, and a weakening economy, thereafter switching to new modes of organizing. These observations complicate the 'dominance thesis' proposed by Pempel because the primary criterion for dominance largely appears to be electoral success. However, this can include all parties that dominate politics merely by virtue of the absence of a viable opposition, or popular social movement activity that challenges their dominance. In this regard, Bengal's CPM appears to fit the conditions for dominance far more than Kerala's. The absence of a viable opposition to the Bengal CPM means that it faces fewer challenges to its dominance than does the Kerala CPM. Of course, we can also argue that this is because it is doing a better job than Kerala's CPM, but the evidence does not suggest that.

The stalling of formal democracy to competition between two or at most three parties creates confusion over what one-party dominance actually signifies. Is it hegemony in the sense of consensual democracy at work, or is it a lack of alternatives? 'One-party dominance', examples of which include the SAP in Sweden, the Liberal Democratic Party in Japan and, within India, the CPM in Bengal (Pempel 1990), poses distinct problems for democratic theory and practice, for it makes such a party less prone to challenge, adaptation and accountability. Parties that have consistently managed to win elections over a period of several decades are presumably in a better position to implement strong public policy agendas, but one-party dominance often creates a slower reform tendency when not challenged by other parties (see Echeverri-Gent 1992 on sluggish reforms in Bengal and evidence provided in Chapter 5).

A second problem with collapsing dominance and hegemony is that it reduces consent to the act of voting, which flattens the notion of politics, conflating democracy with infrequent and routinized procedures. Instead, it is important to recognize that while electoral success in a liberal democracy provides an important measure of a party's relevance in the political arena, as well as the opportunity to let dominance beget more dominance, electoral successes do not necessarily reflect a party's capacity or willingness to create reforms, particularly structural reforms that reshape existing class structures and patterns of domination. ${ }^{24}$ But in what factors does such 'capacity' lie, and what is its relationship to hegemony?

Gramsci's original use of the term hegemony (of the proletariat) contained some idea of 'consent' or popular acquiescence, that is, an ideological-political 
leadership exercised by the party among its followers. ${ }^{25}$ The hegemonic project of a party would, as Jessop (1990) argues, be concerned with more than accumulation strategies, an area that most analyses of parties and social policies focus their attention on (except for the state autonomy theorists who examine the visions, goals and interests of state officials and bureaucrats) (emphasis mine). However, including the contested sphere of civil society in a theory of democracy suggests an attention to how parties must also authoritatively define and/or put into effect social reforms, political stability and 'moral regeneration' (ibid.) Hegemonic projects are thus oriented towards - to borrow a term from Gramsci - the 'national-popular', not just class relations (which is mere economism). In attempting to understand the degree of Kerala's left's ability to push through crucial anti-poverty reforms, the role of communists in capturing the nationalist anti-colonial movement, their subsequent involvement in the movement of linguistic regional unification of Kerala (Aikya Kerala), and other such projects that eventually drew a powerful set of lower caste and class movements into politics, would be a crucial part of the explanation of their ability to redefine the state's priorities for several decades in the direction of critical anti-poverty reforms and measures, despite or perhaps because of not having continual tenure in government. It is important, however, that we do not lose sight of the importance of accumulation as the bottom-line condition for hegemony. Economic crisis, joblessness, declining profits and wages make left parties particularly vulnerable in the electoral arena. What this book emphasizes is that hegemony runs deeper than accumulation, because it is a quality of a regime whose goal is reform and redistribution of profits even while ensuring the conditions that make them possible.

We can present the broader argument schematically: the strength of subordinate class mobilization and associationalism combined with a strong left presence, both parliamentary as well as extra-parliamentary, produces the strongest institutionalization of anti-poverty reforms (Kerala). This theory concurs with several key works in political sociology which hold that the strength of workers' insurgency and unions is positively related to the institutionalization of social democratic policies (see Korpi 1980; Piven and Cloward 1977).

\section{Predicting anti-poverty reforms}

Subordinate class

Weak

Strong

associational strength

Left party

parliamentary strength

\begin{tabular}{lll}
\hline Weak & $\begin{array}{l}\text { Weak reforms } \\
\text { (Uttar Pradesh) }\end{array}$ & $\begin{array}{l}\text { Weak reforms } \\
\text { (Bihar) }\end{array}$ \\
Strong & $\begin{array}{l}\text { Moderate reforms } \\
\text { (Bengal) }\end{array}$ & $\begin{array}{l}\text { Strong reforms } \\
\text { (Kerala) }\end{array}$ \\
\hline
\end{tabular}




\section{State autonomy and legacies}

Legacies of state action are a crucial part of the story of Kerala's successes, and in closely examining this aspect of historical continuity and discontinuity, this book raises some important comparative issues for the study of welfare and the post-colonial state. As discussed earlier, much of the literature on Kerala, with few exceptions (see Sen 1991), is strikingly silent on the issue of the existence of a strong welfare state legacy in the nineteenth century, and its consequences for Kerala's subsequent social developments. 'State autonomy' theorists such as Skocpol (1985) and Weir and Skocpol (1985) have argued that policy legacies carry over into welfare states in Europe for long periods of time; this argument can equally be applied to the case of Kerala. One could argue that Kerala's developmental patterns were determined as far back as the mid- to late nineteenth century through major reforms bequeathed by its princely rulers. ${ }^{26}$ Even if this is so, the important question is to trace exactly what effects these legacies had on the rise of subsequent policy regimes.

That this question has created much confusion in the literature on Kerala can be seen in an exchange between three well-known commentators on Kerala in the New York Review of Books. ${ }^{27}$ Responding to Amartya Sen's emphasis on nineteenth-century princely state initiatives in education in the southern principality of Travancore, anthropologists Richard Franke and Barbara Chasin argued that Sen's neglect of the radical traditions of the state were 'misleading'. As they argued, "[t]hough he does credit recent "left wing governments", he gives far too much weight to Kerala's pre-independence rulers' stress on public education, and to a tradition of inheritance through the female line' (1991: 72). Certainly, it could thus be, as Sen argues, that reforms in land tenure, state involvement in public health, education and caste reforms in the two princely states of Travancore and Cochin suggest Kerala's lead in social development preceded the entry of the communists, and raises the question of how much historical weight to place upon the left tenure in power. Moreover, does not the somewhat weaker development of social policies in Bengal in fact reinforce the argument that left rule is of lesser consequence than other factors such as colonial legacies and social structure in determining policy regimes in a post-colonial society?

This is an interesting question, one which has received some attention. For example, Hansen and Stepputat (2002: 28) argue that new political regimes have to produce a coherent 'state project' in the aftermath of decolonization so as to carry out crucial reforms. In other words, political forces must undertake institutional reforms and 'reinvent' the state. Sudipto Kaviraj (1997: 56) argues that the Congress government in newly independent India ushered in a 'period of fast and crucial historical change' between 1946 and 1950 belying the 'myth of exaggerated continuity' between the late colonial and early independence era. This is a curious view, given that the Indian state was not founded in 1947, even if the new regime undertook major institutional reforms. A careful analysis must probe both the continuities and ruptures in politics that independence and 
Congress governance enabled. In practice, thoroughgoing reinventions of the state are rarely carried out even by parties professing such revolutionary objectives. In India, moreover, the Congress Party had been a part, however unwilling, of the colonial state since at least the 1935 Government of India Act, making it simultaneously insurgent movement and ruling party in a number of provinces.

This book will argue, particularly in Chapter 3, that where state welfare legacies were in existence during the colonial era, for example in the princely state of Baroda in western India, there was no necessary translation into a welfarist state in the post-independence era. There are complicated reasons for this that include the size and influence of the prior state, and the redrawing of state boundaries in the 1960s. However, undoubtedly intervening political changes would affect whether welfare legacies were upheld, extended or forgotten. This book thus also traces the importance of an accompanying legacy to state formation in Kerala, that of caste reform movements which intersected with state penetration of society to enhance state capacity building. This legacy was perhaps more important for the future political trajectory of Kerala than the state legacy itself, and explains why the reformist aspects of state action were kept alive by a host of social movements in modern Kerala.

\section{Method of enquiry}

This book attempts to break away from the standard narrative of communist ascendancy in Kerala. ${ }^{28}$ Instead, its goals are primarily analytical, touching upon questions that are fundamentally comparative in nature. In addressing the specificities of a 'case', that is, in attempting historical specificity as well as generalization, the method employed here deviates from most standard social science models. The predominant model for social analysis is what Abbott (2001) calls 'general linear reality', which assumes that the units of analysis are fixed, and can be grasped as variables. ${ }^{29}$ Single case-based analyses are often anathema to comparativists, for they are seen as merely inductive and thus non-falsifiable (King et al. 1994; Kiser and Hechter 1991). When cases are used, they often do the work of narratives, using variabsles as subjects (Abbott 2001: 135). Yet, 'general' theories, that is, theories that are not specific to cases and in effect cut across their idiosyncrasies, are probabilistic statements. They can suggest the sets of variables most likely to yield a particular outcome. But to establish causation, or put differently, to specify the time-space conditions under which connections between variables are true, we must test these theories in specific cases. Without attention to causation socio-historical analysis loses its raison d'etre, and collapses into mere narrative and historicism.

The aim of this book's enquiry is to develop a historically specific theory that is time-sensitive yet inherently theory-driven, comparative and generalizable (for other such studies, see Kimeldorf 1988 and Seidman 1994; see also Paige 1999). Temporally and spatially specified concepts are necessary for explanations of 
specific outcomes in specific cases, and involve an event-centred rather than a variable-based approach to historical explanation (Aminzade 1992; Sewell 1996). Historical sociologists have always recognized that social reality happens 'in sequences of actions located within constraining or enabling structures', and increasingly, greater methodological attention is being directed to analyzing historical processes (Abbott 1992: 428).

The search for causality within a narrative is one among several methods of searching history to understand the present. This search involves, as Weber argued, a series of abstractions which attempt to locate the cultural significance of an event, often involving a 'decision' between two possibilities - one that was actualized, the other suppressed (Weber 1949: 171; see also Haydu 1998). Weber argued that counterfactuals are the best way to analyse the course of history. He emphasized that although they involve an 'imaginative re-enactment' of history, each counterfactual must be based upon 'objective possibilities', that is, a consideration of what was actually possible. This is not to call for the equivalent of 'historical econometrics'. Following Burawoy (1990), one may argue that both counterfactuals and comparisons conceived as if 'standing outside of history' or by 'freezing history' are simply positivistic. Yet looking at history only 'as it happened' is in fact open to the dangers of historicism and determinism, and recognizing that what happened was also simultaneously the erosion of other alternative possibilities involves a real engagement with history. For Weber, in fact only a deterministic 'science' could refuse to conceive of other possibilities, for in such positivistic and empiricist knowledge there are no abstractions, only 'facts'.

How do we pose counterfactuals while staying faithful to historical specificity? One approach is clearly through historical investigation itself, which can reveal trajectories taking a different path at particular turning points. Such an analysis is fruitfully employed in Zeitlin's Civil Wars in Chile (1934), or in Griffin's (1993) analysis of a lynching event in the rural south. Alternatively, counterfactual questions can be answered by the use of comparative evidence for instance, we can look at those cases where a certain event did not occur despite comparable initial, generating conditions. These intertwined methods of analysis yield a generalizable theory through detailed, historical and substantive analysis the main point of which would be lost without the aid of these tools of analysis. This mode of analysis, combining a range of primary sources with extensive historical monographs, has a long and productive lineage in historical sociology.

In specifying Kerala's distinct trajectory through comparisons and counterfactuals, this book draws on research in several other cases within Indiathe princely states of Mysore, Hyderabad and Baroda in the colonial era, and the post-independence states of Maharashtra, Andhra Pradesh, Bihar and Bengal being the most significant ones. The Indian nation-state (and the loose amalgam that existed during the colonial era) is an ideal ground for comparative analysis, for holding constant certain factors such as its position in the sphere of 
international relations, geography, ecology, religion and early political formations. This provides a range of variations in key social, political and economic preconditions and outcomes. These cases are important because they highlight other possible pathways for Kerala - sharing some of the same conditions, yet ending up with different outcomes. These cursory comparisons cannot take the place of the fine-grained analysis of single cases, but they can help to avoid just-so stories that do not explain why something happened. However, Bengal is chosen for more in-depth analysis because it highlights distinctions concerning the roles of left parties (in this case the same left party). It is a crucial case because it shows that a left party with a significant social base can make some changes when in power, but is highly limited unless it maintains a strong connection to its insurgent and movementist character. In a formal, parliamentary democracy, movements and parties are limited by the existence of political competition as well as the overall policy emphasis of global politicaleconomic imperatives. Yet change is possible, indeed significant change, if there is a dynamic, synergistic relationship between parties and movements. Indeed, this book suggests that one without the other - movement without party or party without movement - is unlikely to shift political power in ways that substantially reduce poverty or achieve comprehensive development. 


\title{
2 The social bases of rule and rebellion
}

\author{
Colonial Kerala and Bengal, 1792-1930
}

This chapter traces the effects of direct and indirect British rule in the three regions comprising Kerala on the potential for popular insurgency against the state, landlords and capital. Using Bengal and other cases as comparisons, the chapter also asks why this potential often did not translate into rebellion. Nationalist and Marxist historiography in India have tended to assume that British colonial policies of land tenure, taxation and commercialization laid the preconditions for popular movements against the British. But this must be demonstrated, as the anti-colonial movement and other forms of popular insurgency had distinct geographical, regional and structural bases. Claims about any linear correspondence between colonial policy and popular insurgency, in fact, appear unsustainable on closer inspection.

British land tenure policy and commercialization, the encroachment and growth of the state in new arenas of social life, and the increased salience of caste as a means of characterizing Indian society help to explain the types of rebellions that emerged during the mid- to late colonial era. This is a broader range of factors than are often included under the rubric of 'political economy'. This allows us to understand how insurgency could be enabled or suppressed not only by the existing relations of production, but also by the form of the state, the ideological-cultural mechanisms of social hierarchies, and the organizational and 'mobilizing structures' that bound different groups internally and externally.

Undoubtedly, colonial penetration often increased the potential for, if not incidences of, peasant rebellion (Scott 1976). Raised taxes and market intrusion, as James Scott argues, pushed self-sufficient peasant households over the edge of survival, as they were increasingly subjected to market fluctuations and failures. In turn, the moral economies from which they drew their sustenance were ruptured over time. The Great Depression of the 1930s is rightly recognized as a crucial watershed in the rise of rebellions against colonial states. This also extended to the newly industrialized working classes, who were drawn from rural areas in search of higher wages. Despite these crucial insights, the general theoretical question about the relationship between colonial political economy and the potential for class formation among peasants and tenants as it has been posed in the literature has been insufficiently sensitive to the colonial context of 
the class formation of peasants (see for example Paige 1975; Wolf 1969; Zagoria 1971). ${ }^{1}$ Most of these theories, written as they were in response to the wave of peasant insurgencies in the $1960 \mathrm{~s}$, sought to prove the rationality of peasant action against perspectives that emphasized their conservative mentality. The search for general maxims of peasant behaviour, however, had the consequence of abstracting from both the political system, that is, the state, and 'extraeconomic' relations between 'classes', such as kinship, ethnicity, or caste. ${ }^{2}$

The colonial state's legal-institutional means of classifying, sorting and ordering a population was a key aspect of colonial rule, which cannot be reduced to a purely economic dimension (Mamdani 1996). In the specific case of colonial India, the new relations of domination and surplus extraction were mutually entwined with pre-colonial caste relations, and in many instances articulated with religious divisions. ${ }^{3}$ The British policy of forming alliances with specific castes and land-controlling groups (thus by default specific religious groups, when religious lines reinforced property relations), created new imbalances in the prevailing, pre-colonial social relations of domination and extraction. This is because land-controlling groups were buttressed with the legal authority to intensify the exploitation of the cultivating classes when the British granted absolute private property rights to some caste groups, and denied the validity of the landlords' moral obligations to tenants in times of economic distress or that of pre-existing 'traditional' communal rights to land. The British did not apply a uniform policy throughout India; indeed, the piecemeal and somewhat cautious colonization of India was achieved through a series of trials and errors in land tenure policy. Thus the effects of colonial rule on the potential for class formation further depended on its specific form, for instance, whether it was 'direct' or 'indirect', the kinds of political alliances formed by the British with pre-existing rulers and propertied groups, and related to these two factors, the land tenure policies of the British. Put briefly, we have to analyse the form of rule, the means by which the British colonial state 'penetrated' Indian society, and formed new state-society linkages.

\section{General hypotheses about peasant rebellion/radicalism}

Since the population of Kerala, despite rapid proletarianization, was largely rural, an enquiry into communist ascendancy would have to examine the sources of agrarian radicalism that underpinned it. Perhaps the most pertinent theory to begin with, given the cases presented here, is Paige's (1975) argument that sharecropping relations tend to be associated with support for revolutionary parties and insurrectionary action. Paige's model is based upon a (strict) definition of class 'in terms of relations to property' (1975: 10), whereby the cultivating and non-cultivating classes are locked into specific and mutually dependent interests. ${ }^{4}$ The diagram below shows Paige's schema of how sources of income and forms of agricultural organization are correlated with expected forms of agrarian movements. The two boxes of particular interest for us are the 
commercial hacienda and sharecropping systems, both of which can be seen as the two alternative forms of agricultural organization in which landowners derive their income from land and cultivators derive their income from land or wages, and both of which lead to radical insurgency among peasants.

\begin{tabular}{|c|c|c|c|}
\hline \multirow{3}{*}{ 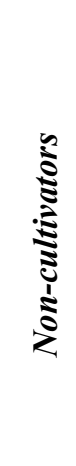 } & \multicolumn{3}{|c|}{ Cultivators } \\
\hline & Land & $\begin{array}{l}\text { Commercial hacienda } \\
\text { Revolt (Agrarian) } \\
\text { (Bihar, United Provinces, Andhra) }\end{array}$ & $\begin{array}{l}\text { Sharecropping } \\
\text { Revolution } \\
\text { (Kerala, Bengal, Bihar, Andhra) }\end{array}$ \\
\hline & Wages & $\begin{array}{l}\text { Smallholding } \\
\text { Reform } \\
\text { (Madras Presidency) }\end{array}$ & $\begin{array}{l}\text { Plantation } \\
\text { Reform }\end{array}$ \\
\hline Note: & $\begin{array}{l}\text { Paige (197: } \\
\text { Regions in b } \\
\text { colonial era } \\
\text { dominant. }\end{array}$ & $\begin{array}{l}5: 11) \text {. } \\
\text { brackets contain elements of a number of } \\
\text { in India, but they are placed in the box }\end{array}$ & $\begin{array}{l}\text { different property relations during the } \\
\text { here the particular agrarian relation is }\end{array}$ \\
\hline
\end{tabular}

While Paige's interest-driven model (with interests understood as derived from the structure of property relations) treats peasants as 'classes' in the strictly Marxian structuralist sense, Scott (1976) and Moore (1966) argued that the extent to which peasants are embedded in 'communities' - that is, the strength or weakness of peasant communities - explains the likelihood that peasants will rebel, given other conditions such as deterioration in landlord patronage, subsistence crisis, and the penetration of market relations (Scott 1976: 201; Moore 1966: 475-76). This characterization treats the fundamental class character of peasants as a 'dependent variable', and allows us the possibility of understanding how pre-capitalist social relations in articulation with capitalist forms criss-cross religion, ethnicity, caste, status and class (as defined by Paige), make the possibilities of rebellion highly contingent on whether these boundaries of 'community' prevent or encourage 'class' action. Of course, it must be emphasized that while 'community' forms the basis of identity and solidarity, it is also a material entity. Indeed, for Scott, landlords and tenants, once locked in systems of patronage and duty (moral economies), were now increasingly delinked by market rationalities. Among peasants the bases of solidarity in fact make all the difference between rebellion and non-rebellious responses (such as quiescence, migration or other work slowing tactics). As Moore stated, 'the 
absence of solidarity ... puts severe difficulties in the way of any political action' (1966: 475). Conversely, in a 'rebellious and revolutionary form of solidarity, institutional arrangements are such as to spread grievances through the peasant community and turn it into a solidary group hostile to the overlord'. Put briefly, between the potential for, and actuality of, rebellion, organization and solidarity are key variables. However, this theory has to contend with the strong relationship between sharecropping and rebellion. This chapter evaluates how strong this relationship was in British India, and demonstrates the importance of the class-state relationship (the political) in explaining actual rebellions.

\section{'Direct' British rule, 'proto zamindari' policy and the disruption of landlord patronage: Malabar, 1800-1930}

In pre-colonial Malabar, there was no central ruler, and the largest landlords were the upper castes who maintained their own private armies. The vertical ties between landlords, upper tenants and lower tenants/cultivators corresponded closely to the rigid caste hierarchy prevalent at the time. The two dominant castes - Namboodiris (Brahmins or the priestly caste) and Nairs ('kshatriyas' or the aristocratic caste) - stood at the apex of the system of customary obligations and rights. Together the two dominant castes appropriated the largest share of the cultivator's product - (the Brahmins were only 2 per cent of the population of Malabar, but nearly half (46 per cent) of the principal jenmis or landlords. The Nairs were 14 per cent of the population, but 41 per cent of the principal landlords (Radhakrishnan 1989: 39).

The pre-colonial system of rights and obligations between landlords and tenants called for each claimant to the land and its surplus - jenmi or 'landlord', kanomdar or intermediate tenant, and verumpattomdar or cultivator - to share one-third of the produce equally among them. All parties recognized this tripartite claim to the soil and its product. Nairs traditionally acted as arbitrators in cases of dispute, and enforced the customary rule of dividing the surplus. An elaborate set of rituals and social norms dictated the place of each caste within the hierarchy. Namboodiris maintained elaborate untouchability rules for the low, 'polluting' caste Tiyyas, Cherumans and Pulayas. A Tiyya had to keep at least 32 feet away from a Namboodiri, and a Cheruman, 64 feet (Mayer 1952: 26). Nairs were also considered to pollute Namboodiris, but only by contact and not by distance. The Nairs were traditionally a military caste, who lived in matrilineal joint families (taravads). Despite their lower status to the Namboodiris, their higher status compared with the 'untouchable' castes was clearly demarcated. Low castes were not allowed access to public roads when they were in use by the upper castes, and were banned from entering temples. Speaking of the low caste Pulayas, an observer in the early nineteenth century remarked:

they were not permitted to breathe the same air with the other castes, nor to travel on a public road; if by accident they should be there, and perceive a 
brahmin or a Nair at a distance they must instantly make a loud howling, to warn him from approaching until they retired. ... If a Nair accidentally meets a Pooleah on the highway, he cuts him down with as little ceremony as others destroy a noxious animal: even the lowest of other castes will have no communication with a Pooleah.

Forbes 1813: 395

There is a large literature on the caste system in Kerala, and what interests us from a theoretical perspective is that the rules governing caste segregation and pollution were perhaps the most stringent in colonial India. Transgressions of caste rules were often put down with force and violence by the ruling castes. This was the system the British encountered when they annexed Malabar in 1792 and brought it under direct rule. ${ }^{5}$

Generally, where the British created or strengthened landed intermediaries between the state and peasants by granting them enhanced rights in land, the possibilities for class-based resistance were stronger, because landlords were given new rights over the peasants' surplus. Under the zamindari ${ }^{6}$ system, for example, the British sought to identify the class of pre-colonial landholders to whom they would grant the right of revenue collection and private property. In the provinces of Bihar, Bengal, the United Provinces and Malabar, where landlords were fortified by colonial rule, the class dichotomy between landlords and tenants, or rich peasants and sharecroppers (as in the northern frontier areas of Bengal) was as a consequence sharpened (Bose 1986). In Malabar, the sharp caste-class divide made the potential for peasant rebellion particularly acute.

In 1802 revenue officials introduced what they conceived of as the 'purest form' of the ryotwari policy in Malabar. However, this policy was ironically much closer to the zamindari system, because of what has been termed a 'misidentification' 7 of the prevailing rights in land. The British regarded the landlords as the cultivators (or ryots) instead of the actual worker of the land, that is, the tenant-at-will (verumpattomdar). In 1802 the British stipulated a written and contractual agreement between landlords and peasant cultivator, holding that the landlord possessed 'the entire right to the soil and no earthly authority can with justice deprive him of it' (Report on the Land Tenures of Malabar, cited in Panikkar 1989: 20). He, it was argued, 'possessed a property in the soil more absolute than even that of the landlord in Europe' (Board of Revenue, Proceedings, 5 January 1818, vol. 2537, cited in Panikkar 1989: 21). The kanom tenure, which was until then considered lifelong, was now interpreted as a lease renewable every twelve years. The holders of kanom tenure were mostly Nairs, who in the pre-British era possessed full authority over their territorial unit (or tara). Each tara consisted of several households, who together controlled large tracts of land. In effect, they were co-proprietors of the land along with the landlords. With the designation of landlords as 'dominus', the Nairs lost their precolonial claims to the land (Logan [1887] 1951: 608). The British had indeed gone a step further than in the case of the zamindars of Bengal, by regarding all 
the wastelands and thus 'every inch of land' in Malabar as the private property of landlords (Varghese 1970: 25). Moreover, the colonial state now supplanted village councils for arbitrating land and rent disputes. As a consequence all tenants and cultivators lost access to the traditional institutions that might have enforced the customary obligations of the landlords. The British did not allow landlords to reduce rents in times of drought or crop failure as was customary in the pre-colonial era (Kurup 1988: 6). In effect landlords appropriated new rights that arose from the replacement of custom by contract; in the eyes of the state the customary obligations that landlords had towards their tenants were no longer relevant.

The tenancy arrangements in colonial Malabar were a further burden to the tenants under the system of revenue collection enforced by the British. In 1805 revenue officials imposed a settlement whereby the actual cultivator continued to retain one-third of the net produce after deducting from the gross produce 'the seed and exactly the same for cultivation'. The remaining two-thirds was to be shared between the state and landlord - 60 per cent to the state and 40 per cent to the landlord (Panikkar 1989: 6). It was the landlord's responsibility to pay revenue to the state; however, he simply passed this burden on to his tenants below him. By 1900 the revenue demand of the colonial state moved to 77 per cent over what it was in 1792 (Innes and Evans 1951: 347).

The tenurial hierarchy that had developed over the course of the nineteenth century resembled the complex ladder of tenancy that is commonly found in wet rice cultivation (Zagoria 1971). Landlords would either lease land directly to two or more layers of verumpattom tenants and sub-tenants, who would oversee cultivation of the land by agricultural labourers, or there would be one or more layers of kanom tenants who would sublet the land to verumpattom tenants.

\section{Intensified landlordism and its effects on agrarian relations}

The consequence of British colonial penetration in Malabar was to increase the sway of the landlord, with little protection available to tenants against his depredations. Landlords resorted to two legally sanctioned strategies to maximize their rents: evictions of tenants, and shorter leases. During the second half of the nineteenth century, a market in kanom land began to develop, largely as a consequence of the rise in prices of agricultural products. Landlords could, under these conditions, seek the tenant who would pay the highest rent by evicting current tenants, or extracting a higher rent from the tenant by threatening eviction. When the District Collector of Malabar, William Logan, began to enquire into the causes of Muslim peasant rebellions which had begun erupting in the mid-nineteenth century, he noted that annually about one in twenty cultivators had an eviction decree passed against him. This figure did not represent the real incidence of evictions, because most tenants could not afford the necessary litigation, and therefore numerous cases of evictions went unrecorded. Often because there was no procedure for landlords to issue receipts 
for the rents, cultivators had little basis for defending themselves (Zagoria 1971: 42).

A second strategy that landlords resorted to in order to maximize their surplus was to shorten the duration of the lease. Landlords or jenmis began to replace the kanom or 'superior' tenancies with verumpattom or 'inferior' tenancies during the mid-nineteenth century. Half of these verumpattom leases were of less than a year's length, which effectively reduced a large number of tenants to the status of tenants-at-will. By the late nineteenth century, almost 61 per cent of the total leases were 'inferior' verumpattom leases. The kanom tenure allowed the tenant to be part-proprietor of the soil, and claim one-third of the net produce. In practice, he was permanently attached to his holding, and the landlord feared ousting him because the 'intermediate' tenure-holders (kanakkaran) were his chief means of income and also his armed retinue (Radhakrishnan 1989: 28). But the backing of the legal apparatus of the colonial state balanced out the landlord's dependence on the kanakkaran (also known as kanomdars) by making him the only recognized proprietor of the land. Another mechanism that landlords used against intermediaries were overleases granted by the landlord to a third party (Panikkar 1989: 44). These were often given to a close relative in exchange for initiating legal proceedings against the 'intermediate' tenants.

Apart from the legal means that landlords could use to extract a larger surplus from the peasants, there were all sorts of 'extra-legal' means that derived from their higher ritual status in the caste hierarchy. Thus landlords were able to, in the absence of resistance from peasants, demand food-grains and other produce during festivals, at harvest season and often simply in normal times. In other words, although their paternalistic obligations to tenants were disrupted by colonial intervention, landlords could continue to use pre-colonial customary 'rights' to squeeze the peasants.

While colonial land tenure policies directly caused the rise of 'excessive' landlordism or disruption in landlords' patronage, fluctuations in prices of grain and garden produce indirectly exacerbated this effect. In less than a decade, from 1851-52 until 1859-60, prices of paddy, coconut, pepper and coffee roughly doubled (Logan [1887] 1951: 718). This had the effect of making land a more valued and sought after commodity than it had ever been. Landlords, as Logan noted, 'influenced partly by the rise in prices of produce and partly by the novel view of the courts as to their real position, had at last begun to feel their power ... and to exercise it through the courts (ibid.).

Over the course of the nineteenth century, as the balance of power began to shift away from tenants, growing population density threatened to make the situation worse. Zagoria (1971: 149) argues that highly populated areas create a landless population that is worse off than those in sparsely populated areas. Moreover, densely populated areas are characterized by a rich surplus in terms of output per acre, which creates a potentially 'conflict-ridden' situation between the landed and the landless. In Malabar, the population rose from1,514,909 in the year 1851-52 (Logan [1887] Vol. 1: 81) to 2,651,900 in 1891 (Shea 1959: 64), 
rising by roughly 2 per cent every year after that. However, population increase ceased being a major factor after 1911 because of the increased opportunity for cash crop cultivation. In the wetland areas devoted to paddy or wet rice cultivation, the population density per acre rose from 5.60 to 6.55 between 1911 and 1931 (figures before 1911 are not available). But it remained more or less stable with respect to the total area cultivated (2.23 in 1911 and 1931) because of the expansion in dry land cultivation (mostly devoted to cash crops such as coconut, arecanut, pepper, turmeric, ginger and groundnuts) particularly between 1921 and 1931 (ibid.). Indeed, the rate of growth of dry land cultivation jumped between 1921 and 1931 as population rose simultaneously. The expansion of wetland cultivation, on the other hand, showed little change. Thus the population growth was absorbed by the expansion of dry land cultivation. This factor would appear to contradict Zagoria's emphasis on population density or pressure on land as a factor promoting the potential for radicalism. Instead, in Malabar during the 1920s and 1930s, population pressure led peasants towards dry land cultivation where they grew mainly inferior quality rice, millet and pulses (Panikkar 1989: 34). The availability of cultivable dry land, then, may have mitigated the possibility of peasant unrest.

By the late nineteenth and early twentieth centuries, large numbers of tenants, particularly in north Malabar, had become market-integrated. In 1920-21 34 per cent of the total cropped area was under cash crops (Varghese 1970: 109). Small cultivators found they could make quick profits by growing coconuts and peppers for the world market. ${ }^{8}$ But most of their lands were taken out on an improving lease, also known as a kuzhikanam, which although assuring cultivators lifelong tenure, in practice lay somewhere between the verumpattom (tenant-at-will) and kanom leases. ${ }^{9}$ As one contemporary observed, the first five years of the tenancy were the period of maximum investment of money and labour; however, tenants were frequently evicted just when the fruits of their investment were beginning to pay off (Rao 1924: 31). The evidence, then, shows that most peasants were indeed subject to rack-renting, 'extra-legal' landlord demands and insecurity of tenure as a direct result of the new tenurial system implemented by the Madras government. It also points towards the combined effects of the peasant's vulnerability to market fluctuations, and his dependence on landlords (for loans in times of crisis, and because of his insecurity of tenure), on the potential for radicalism among the smallholders of Malabar.

Scholars of peasant rebellions have argued that the Great Depression was a watershed event for peasants across the globe, because it broke apart the selfsufficiency of 'middle farmers' (in Wolf's (1969) thesis), and ruptured patron-client relations between landlords and tenants (in Scott's (1986) thesis). Both observations appear to be correct when we look at the evidence from Malabar. When the Depression hit Malabar in the 1930s the prices of cash crops, particularly pepper and coconuts, fell rapidly. This sharp drop in prices followed what had been a spurt in the growth of cash crops, primarily coconut and pepper, for the world market, with prices peaking in the 1920s. By 1934 the price of 
coconut had dropped 67 per cent from its level in $1928-29 .{ }^{10}$ Prices of pepper suffered a similar decline. The consequence of this price fall was the devastation of many small cultivators, who were forced to turn to cultivating subsistence crops. The new resettlement scheme in 1929 had increased rent for all types of land by 18.75 per cent, which the colonial government justified by pointing to the rise in prices of cash crops, which had occurred then (The Hindu, 7 May 1934). At current prices in 1934, this rent thrust most market-integrated peasants into poverty. Particularly telling evidence is the rise in proportions of agricultural labour to which smallholding families had to turn in order to supplement their falling incomes (Kannan 1988: 46). Between 1921 and 1931 the percentage of cultivating tenants to the total agricultural population fell from 34 per cent to 21 per cent, and the proportion of agricultural labourers rose from 58 per cent to 68 per cent (ibid.). ${ }^{11}$ The picture that emerges is certainly one of an impending agrarian crisis, and a crisis of moral economy. Yet two factors suggest that we need to look further to construct a theory of agrarian insurgency in Kerala: (1) the timing of rebellions, and (2) the comparative dimension which suggests that similar crises occurred in other parts of India, and were often the site for communist insurgency, but were associated with very different political outcomes. In other words, the ecological correlations that associate communist votes with structural variables are the products of political projects that emerge from within these conditions, but exercise independent effects.

\section{Time, structure and rebellion in Malabar}

Paige's argument suggests that sharecroppers in rice producing areas are the most likely to engage in collective rebellion of a radical or revolutionary kind. His argument which draws on the case of Kerala as a crucial illustration - is that the need for irrigation in rice production creates close interdependencies, which in turn form 'natural' bases of solidarity. However, in Malabar, the ecological factor of abundant rainfall made irrigation works and the related organization of village cooperation and highly centralized states mostly redundant. Instead, there was historically a strong tendency towards nucleated settlements (not villages), in which vertical ties between landlord and tenants/labourers were dominant over horizontal ties among labourers and tenants (Mencher 1966: 143). Peasants who were attached to specific landlords lived around the tara or landlords' household, rather than in separate streets or villages as found in the neighbouring region of Tamil Nadu. Thus the absence of irrigation, which meant that peasants were not interdependent on a regular, daily basis, and the nucleated settlement pattern, inhibited the creation of a peasant community that could have contributed to peasant solidaristic action against landlords.

On the other hand, the 'objective conditions' found in the wetland areas of north and south Malabar appear to correlate perfectly with the conditions outlined in Zagoria's (1971) theory of agrarian radicalism, which is closely related to Paige's argument. Taking the rural communist vote as his dependent variable, 
Zagoria argues that 'landlessness in combination with high rural population density' are the two most significant factors associated with it (1971: 147). He measures landlessness as a composite of three variables: agricultural labourers as a percentage of all cultivators, tenants as a percentage of all cultivators, and holdings of less than 1 acre. However, according to Zagoria neither landlessness nor high rural population density taken alone account for the communist vote; they must exist in combination. This combination, particularly found in wet rice cultivation, leads to a 'conflict-ridden relationship between the landowners and the landless engaged in a desperate struggle for survival' (ibid.: 149). In such systems, he argues, land is a highly valued commodity. In the context of high population densities and with the intensification of surplus extraction by landlords, interests over land become sharply polarized.

This theory applied to Malabar runs into an empirical difficulty though, namely, that it was Muslim tenants in south Malabar who responded to the excesses of landlordism, and not Hindu tenants in either the south or the north. In other words, there were crucial temporal and spatial specificities to the tenant rebellions that occurred in the 'first wave' of the mid- to late nineteenth century, in addition to their being located in a particular 'community', the Moplahs. Muslim tenants and agricultural labourers rose in successive violent revolts against Hindu landlords throughout the nineteenth and early twentieth centuries (in 1849, 1851, 1852, 1896 and finally in the largest insurgency of 1921). Moplahs, as they were known, were originally descendants of Arab traders or of Hindu converts to Islam. Many Moplahs were also traders and merchants. But the class division between landlords and tenants in south Malabar tended to fall along clear religious lines. Except for the uprising in 1852, all the other revolts took place in south Malabar, specifically in two taluks or districts: Ernad and Walluvanad. Both districts shared very similar objective conditions: first, the man-land ratio was high, 1: 0.47 (in acres) in Ernad and 1: 0.56 in Walluvanad. In Ernad rice cultivation took up the bulk of the land (57 per cent of cultivated land), the other crops being gingelly, coconut and spices. In Walluvanad, the major crop was also rice (79 per cent of total cultivated area), and the other crops were coconut, spices and ragi (Panikkar 1989: 66-67). If we look closely we find that wetland cultivation was a greater part of cultivation in south Malabar. ${ }^{12}$ Rack-renting was predominant in wetland or rice cultivation areas, but since this formed the bulk of the cultivation in south Malabar, we cannot easily explain the highly localized character of the rebellions or their confinement to Muslims simply on the basis of excessive landlordism.

To answer this puzzle, two factors appear salient: the ideological basis of religious community among the Moplahs, and the organizational or 'indigenous' mobilizing structures, also part of the constitution of religious community. Both these mechanisms and resources allowed the rebels (Muslim tenant-cultivators who worked under Hindu landlords) to mobilize their rage into sustained attacks on the landlords. In reacting to the excesses of landlordism, Muslim peasants refracted their understanding of exploitation and other grievances through a 
religious lens. ${ }^{13}$ The leadership of the Moplah rebellions was provided by traditional religious 'priests' known as ulemas and thangals. These traditional leaders were able to infuse class-based grievances with powerful religious symbolism. ${ }^{14}$ The sheer cultural defiance that Moplahs could mobilize into attacks that terrorized landlords and colonial officials alike was then unimaginable in the Hindu community. Moplah leaders insisted on Nairs showing them greater respect and courtesy than they did the lower castes. Indeed, a significant number of Moplahs were lower caste Hindus who had converted to Islam. ${ }^{15}$

It could be objected that perhaps the Muslim tenants suffered greater discrimination at the hands of Hindus; however, if we take evictions by landlords as one measure of 'excess' exploitation, the yearly average of the number of evictions of Hindu tenants by Hindu landlords between the years 1841 and 1851 (680) was roughly three times that of the eviction of Muslim tenants by Hindu landlords (232). ${ }^{16}$ Why, then, were the Hindu tenants largely quiescent? Was the caste system, as Barrington Moore (1966: 335-37) argues, a decisive barrier to peasant radicalism, and if so, how? Moore suggests three primary mechanisms through which the caste system might have lessened the potential for rebellion in India, compared with China for example. He argues that caste councils, consisting of a group of leaders chosen from within each caste, served the function of ensuring the self-discipline of their own caste. In the absence of a central organization that could oversee the functioning of the caste system, lower castes simply 'disciplined themselves', and had to learn to accept their place in the social hierarchy (Moore 1966: 337). Transgression of social rules by lower caste members were paid for in fines to the upper castes by the leaders of their own caste councils. In other words, then, caste councils served a conservative function of maintaining the lower castes' position in the hierarchy without challenge. Thu, in comparison to the Moplahs, the organizational structures of daily and community life discouraged challenges to social hierarchies.

A second mechanism that might have lowered the possibilities for rebellion among Hindus was the ability of castes to move up 'to a higher rung on the ladder of self-esteem and disgust' in the caste hierarchy. The possibility of adopting the customs of upper castes such as diet, occupation or marriage practices and thus climb up the ladder - known as 'sanskritization' - also provided pathways to mobility, and worked against the potential for rebellion.

These factors are certainly relevant for considering the absence of 'spontaneous' rebellion in Malabar. The obligatory display of self-disgust and obedience towards the higher castes was so embedded in daily living that even if lower castes did not accept their degraded state, it is difficult to see how they might have imagined any alternative and organized around it. Indeed, there was no real option for exit from caste other than distant migration or religious conversion. Particularly telling evidence of this proposition is provided by the large-scale conversions of lower caste Hindus to Islam and Christianity in south Malabar in the nineteenth century. At the beginning of the century the number of 
agrestic slaves (Cherumans and Pulayas) was roughly 100,000. By 1856 their number was estimated at 187,758 . But by 1871 they were down to 99,009 and in 1881 the population of low castes (no longer slaves as slavery was abolished in 1843) stood at 64,725 (Panikkar 1989). The primary reason for the decline in the numbers of low castes was their conversion to other religions. Conversions acted as a safety-valve, allowing lower caste members the option of exit over the costs of voice.

There is no doubt that one must adopt these explanations with caution, for there are numerous examples of lower caste movements (many within Kerala itself), whose methods of protest were no less militant than those adopted by the more self-consciously class movements. Examples of low caste protest from Bihar, Maharashtra and northern India suggest that even with the powerful mechanisms suppressing the possibilities for dissent, individual and collective protests were not scarce. Neither did caste always prevent modern selforganization, a fact which Moore partly acknowledged. As Gough (1979) has shown, peasant rebellions in India were far from infrequent; over the 200 years or more dating back to the last days of Mughal rule, there were 'at least' seventyseven revolts, engaging on average 'several thousand' peasants, of which thirty affected 'tens of thousands' and about twelve 'several hundreds of thousands'. Indeed, Moore himself cites major exceptions to his theory, namely, the largescale peasant insurrection in Telengana, Andhra Pradesh in 1946 (which I discuss in Chapter 4). In Kerala, the communist movement took firm root in the most caste-ridden villages of Malabar, the same regions in which the strictest practices of segregation were the norm.

These caveats suggest that viewing caste solely as a hierarchy may be problematic, and that the possibilities for horizontal solidarities generated by caste (much like ethnicity and religion) are also important predictors of radical insurgency. As Bouton (1985) and Alexander (1989) have argued, the probability of peasant radicalism sharply increases when there is strong caste-class homogeneity among landless labourers and poor tenants, that is, the occurrence of a 'bipolar' agrarian structure marked by a clear division between landless labourers and landowners (Bouton 1985). This is because caste becomes an additional factor that facilitates peasant radicalism against landlords or the state, acting as a 'ready symbol, idiom and cement for radical mobilization'. Similarly, Alexander (1989: 364) argues that caste-class homogeneity among tenants and labourers provides a 'critical mass of economically and ethnically (caste) homogeneous proletariat'. Both authors draw heavily on evidence from Thanjavur district in Tamil Nadu, southern India, where high levels of tenancy are also marked by the concentration of adi-Dravidas (or untouchables), and regions of Kerala such as Kuttanad and Alleppey, where low caste Ezhavas and Tiyyas also constitute the bulk of poor tenants and landless labourers. These three regions of southern India, located in the states of Kerala and Tamil Nadu, have been traditional strongholds of the two communist parties (CPI and CPM). 


\section{Agrarian bases of rebellion: the comparative cases of Bihar and Andhra}

Radical peasant insurgency was a feature of several other provinces in late colonial India, notably, Bihar (early to mid-1930s) and Andhra (1940s) (the other significant case of Bengal is taken up for a more in-depth comparison in Chapter 5), and thus these areas merit specific attention as comparative foils for the case of Malabar. In particular, to what extent, and how specifically, was Malabar a comparative anomaly - or was it no different in its structural transformation under British rule compared with these other two crucial cases?

\section{Bihar}

Bihar, like Bengal, came under the provenance of the Permanent Settlement in 1793. Landlords, who were granted ownership rights to the land in return for collecting revenue, ruled large estates with the help of an elaborate structure of middlemen, who in turn had developed their own power bases over time. For the first part of the nineteenth century every regulation simply armed the zamindars with more powers, failing to protect the interests of the cultivators (Das 1983: 18). As a result a corrupt and extremely rapacious structure of surplus extraction prevailed in the region, with tenants subject to the personal whims and cruelty of landlords, including the sexual terrorization of women. The hierarchy of rights to the land corresponded with the caste hierarchy - 'middle' tenants who were often drawn from the Bhumihar caste, subleased their land to the poorer tenants (Yadavs or Kurmis). The 1931 census recorded that about 80 per cent of the agricultural population consisted of tenants and agricultural labourers, with the bulk of tenancies being occupancy tenancies (60-80 per cent). The proportion of tenants-at-will or agricultural labourers ranged between 20 and 25 per cent, depending on the region (Damodaran 1992: 71). In 1931 this proportion was smaller than that in Malabar, but higher than in Travancore or Cochin.

In the context of rising population and land prices during the 1930s, landlords began to demand higher rents, often suing tenants over and over again for arrears. As in Malabar, there was a section of occupancy tenants who were able to take advantage of the higher prices; however, the bulk of them were clearly subject to the whim of the newly empowered landlords. Thus landlords often expropriated land from their tenants, as a result of which the percentage of landless peasants increased during the 1930s and 1940s. The critical point of interest for us is the differences and similarities between the agrarian structures of Malabar and Bihar. From the available evidence it would appear that the same tendencies prevailed in the two cases; in other words, there were growing tensions between landlords and tenants, deriving from higher land prices, scarce land, and a tendency on the part of landlords to extract more and more surplus by raising rents, evictions of tenants, and illegal exactions. But the situation in Bihar appears to have been slightly worse. There does not appear to have been a moral economy of patronage or clientelism between landords and tenants; rather, in Bihar, the zamindars were 
largely absentee, 'slothful, devoid of education and abilities', as one observer put it (Das 1983: 19). Thus each landlord maintained an elaborate structure of middlemen - a retinue of record keepers, messengers, rent collectors and the like - who were equally if not more rapacious. As we will see in Chapter 3, these everyday relations translated into an equally ruthless political dimension, wherein zamindars and their amlas (serviceholders) used physical violence and intimidation to obstruct their political competitors on the left. Yet, as we will see, the powerful hold of zamindars did not prevent tenants from organizing and resisting. Neither did caste relations exercise a dampening effect on peasant rebellions. Bihar had a longer history of peasant rebellions than Malabar, but its caste hierarchy was equally brutal. One crucial difference may have been the fact that landlords were largely absentee in Bihar, and did not participate to the same extent as jenmis in the day-to-day relations of patronage that were a central feature of caste relations in Malabar. This probably meant that the moral economy of Malabar's agrarian relations existed at a higher threshold than Bihar's (such as it was), and was more difficult to subject to radical questioning until the entry of radical parties to the left.

\section{Andhra/Telengana}

In Telengana, the south-eastern part of Hyderabad state during the colonial period (and now part of the state of Andhra Pradesh), militant peasant rebellions occurred in 1946 and lasted for several years until 1951, shaking the newly independent Indian government into swift repression. As a surviving derivative of the Mughal empire under the autocratic rule of the Nizam, land tenure was based on categories that derived from the Mughal period. ${ }^{17}$ The dominant agrarian class consisted of jagirdars, nobility who had been granted rights to collect land revenue from a number of villages. In 1949 jagirs accounted for 34 per cent of the villages and 29.4 per cent of the population. Jagirdars tended to be absentee landlords, and gradually it was the revenue farmers under the Mughal empire, also known as the deshmukhs, who came to effectively control the land. The deshmukhs combined moneylending and landlordism, slowly gaining control over the valuable wetlands through the increasing indebtedness of the tenants the 1931 report by Iyengar cited the real rate of interest borne by tenants as 'impossible'. Kesava Iyengar's (1931) survey showed, moreover, that the average size of holdings in Warangal district of Telengana (11 acres of dry land and 3 acres of wetland) were below the state's average and 'insufficient to maintain them at a reasonable standard of comfort' (1931: iii). Yet many of these smallholders simply rented the extra land from larger landholders, and as a result about one-quarter of the total area of dry land and nearly as much of the wetland was leased to tenants.

How much of an exception was Warangal compared with other regions of Hyderabad state? In the three other districts chosen for Iyengar's comprehensive survey of 1931, there were other regions that shared the main characteristics of 
land tenure and indebtedness of Telengana, in some cases even surpassing those of the Telengana districts. Thus the district of Aurangabad in the Marathwada region of Hyderabad had the highest debt per family, as a result of which holdings were transferred at one of the highest rates in Hyderabad state in the years leading up to the survey. Agricultural tenancies hovered at around 30 per cent of the population, with about 75 per cent being tenancies-at-will. In Warangal, a higher proportion of these were unskilled labourers. Yet the superficial similarities between the districts of Marathwada and Telengana dissolve when we consider that wetlands were a larger proportion of lands in Warangal (Telengana) (Pavier 1981: 4). Ownership of wetlands allowed families to produce a surplus, whereas those in even slightly larger dry land holdings could not cover their basic needs. Eighty per cent of the wetlands in Hyderabad was in Telengana (ibid.: 5); as Zagoria (1971) argues, wetland cultivation is the most prone to the zero-sum conflict situation between landlords and tenants - and tenants in Telengana became aware of this through the rapacious methods of land acquisition of the deshmukhs. Many of the landless labourers became the equivalent of agrestic serfs (known as bhagelas), forced to peform labour (vetti). Serfdom simply passed over into the next generation, with bhagelas unable to pay off debts because of the prevailing low wages and high rates of interest. Wage levels for unskilled labourers, for example,were (in kind) 2-3 measures of grain for males and 1.5-2 measures of grain for women - not enough for basic physical survival. In addition, land ownership was highly skewed; in the wetlands 2.5 per cent of occupants held more than 50 per cent of the land (Iyengar 1931: 113). In the case of the wetlands there was excessive monopolization on the one hand, and excessive fragmentation at the other end of the spectrum - which attested to the growing inequality of access to land.

The conflict over wetlands in Telengana gradually extended to the dry lands as they became cultivable over the following decades. Until the 1940s Hyderabad was not particularly integrated into the world market, but that began to change as the indebted small peasants began to grow new crops such as castor, groundnut and sesame for the world market. The dry lands that had once been viewed as unprofitable now became prime cultivable land, much of which was in the hands of the deshmukhs, and which naturally strengthened their economic position. The market raised some fortunes, as in Kerala, but the Depression of the 1930s in much the same way proved to be the crisis point in agrarian relations in Hyderabad. The Director General of Commerce and Industries in the Hyderabad state government cited a 'catastrophic fall in prices' as the cause of the rise in debt and general economic distress of the peasantry (Pavier 1981: 27).

The evidence from Telengana, a crucial site of leftist insurgency in the late 1940 s and early 1950 s suggests the rapid immiseration of the lower peasantry and landless labourers in the aftermath of the Great Depression. As with the jenmis of Malabar, the deshmukhs, universally reviled, were the obvious targets of the communists. But such rapaciousness was not uncommon in most parts of India; what mattered was a rapid proletarianization process in which conflict over land 
increasingly intensified with its growing value, and prevailing structural relations encouraged politicization. At this level of analysis the differences between the structural conditions of communist bases appear to be rather indistinguishable, and a finer grain of analysis is needed to differentiate between the political outcomes of Bihar, Andhra or Malabar. As we will see, one crucial difference between these cases is the higher degree of industrial or agro-manufacturing related proletarianization that occurred in Kerala (this was true to an extent in Andhra but negligible in Bihar). This made possible the worker-peasant alliances that were ultimately radicalizing in the case of Kerala; however, as I have argued, even if such structural differences are accounted for, sensitivity to the issue of the timing of rebellions calls for a theory of the relative autonomy of the political to resolve the problems that arise from lags in timing of rebellions, differences in the regional character of communist insurgency, and in the political outcomes that emerged in these regions.

\section{'Indirect rule' and uneven capitalist development in the princely states of Travancore and Cochin}

Ironically, 'indirect' rule entailed a far deeper transformation of land tenure and caste relations in Travancore and Cochin, than did 'direct' rule in Malabar. This form of rule coincided with the gradual transformation of the East India Company from trading company to political authority. The British were anxious to establish the least costly and most politically stable footing in troublesome regions such as Mysore, Panipat and Hyderabad, where they had been waging costly wars with local rulers. In the princely states, British policy was to create a 'flexible and expert diplomatic system', in order to strengthen friendly rulers and ensure political peace. The 'indirect' system of rule operated through a Residency system whereby a British Resident acted as 'advisor' to the princely ruler, much in the capacity that had once been occupied by an uncle or royal mother (Bayly 1988: 111). Fear of political instability originating in the princely states appears to have been so acute that the Residents exerted enormous influence in the direction of administrative, political and economic modernization in the states. ${ }^{18}$

In general terms, the establishment of a direct revenue extracting relationship between the British colonial state and peasants in Malabar weakened the possibilities for class conflict between landlords and peasants because it was the state and not the landlord that was directly extracting the surplus. It increased the potential for anti-state insurgency, but not necessarily preceded by class formation among peasants. These were largely the ryotwari areas ${ }^{19}$ where the British implemented a policy of eliminating intermediaries from revenue collection, assuming that role for the colonial state itself. The ryotwari system broke up village-level solidarities, because individual peasants were made responsible for revenue payments directly to the state. Moreover, because various intermediaries were weakened, the targets of class antagonism were often not clearly evident (see Hardiman 1981: 176; Washbrook 1989: 218-19). The main 
areas where the British implemented ryotwari policies were Travancore, Cochin, Madras (including the present state of Tamil Nadu), areas of Andhra Pradesh, the princely state of Baroda in Gujarat province, and the middle Deccan region.

After a series of revolts led by the Nayar Brigades against the British, in 1810 the queen Rani Lakshmi Bai firmly consolidated treaties with the British East India Company, declaring herself 'under the guidance and support of the Honourable the East India Company whose bosom had been an asylum for the protection of an infant like Travancore' (Menon 1966: 40). To ensure lasting peace the British sought a complete reorganization of the administration. In order to retain a dominant position for the British, Colonel Munro, the new ResidentDewan of Travancore and Cochin, disbanded the Nayar troops of the monarchies and made them dependent for protection and security solely on the British (ibid.: 42). ${ }^{20}$ 'Intervention in Native States to cure their administrations had become a 'moral imperative' of British society', one writer observed of the post-Mutiny period (quoted in Jeffrey 1976: 71).

While political stability was a constant preoccupation for the British for the monarchies it was a means of securing a monopoly over profits in the valuable pepper and cardamom trade, and facilitating British capital investment in the form of plantations and manufacturing. Apart from encouraging the growth of cash crops such as pepper, cardamom, rubber, tea and coffee, by granting proprietorship rights to cultivators, the Travancore and Cochin monarchies encouraged colonial capital investment in the form of tea plantations and cottage industries towards the mid-nineteenth century. The Travancore monarchy implemented the Pattom Proclamation in 1865 (often called the Magna Carta of the Travancore peasants), which conferred full ownership rights on state tenants and allowed them unrestricted transfer of their properties. The proclamation issued by the monarch stated that: 'the ryots holding these lands may regard them as fully private, heritable, saleable and otherwise transferable property' (Varghese 1970: 64). This major reform had two important effects. First, land was commodified and there followed a spurt in land sales and transfers, and reclamation of wastelands. As the pioneer of the reforms, Madhava Rao noted, 'the natives reclaimed waste in the plains and the Europeans utilized the forests on the mountains, the two classes, then, working apart and peacefully' (ibid.: 8). Second, because land could now be freely transferred, ownership of land became diffused among the various castes and the Syrian Christians, and caste was no longer the sole determinant of land ownership. The reforms, however, did not only ensure the proper conditions for the steady commercialization of agriculture. They also promoted a process of state-building and consolidation in which the Travancore monarchy pitted itself against the landlords and attempted to forge an alliance with the upper layers of the tenantry, merchants and artisanal classes (Tharakan 1994). It was thus that the Travancore state came to 'own' 80 per cent of the land, with only the remaining 20 per cent under the control of landlords. The various nineteenth century state proclamations which granted proprietorship rights to tenants on state-owned land (roughly 80 per cent of the land) were thus 
not simply the product of an 'enlightened state policy' as some have argued (Varghese 1970: 64), but rather the consequence of a strong colonial push towards commercialization and capitalist penetration. The peculiarly dependent position of the Travancore state and the considerable influence exerted by the British Resident on the monarchy belie the notion of enlightened benevolence at work. As a contemporary missionary commented:

Travancore, although nominally an independent state, under the rule of its own native sovereign, is in reality ... a tributary to the British Government, and under its control and protection. All important measures of legislation and finance, the appointment of the higher officials, and even the succession to the ... throne, must be submitted to the British Resident for his opinion and sanction before being carried into operation.

(Mateer 1871: 66).

The immediate consequence of the land reforms for tenants was distinctly favourable. Land reforms resulted in the freeing of Travancore's peasants from substantial rent obligations. The once revenue-paying tenants were now a class of peasant proprietors, who possessed the resources and incentive for raising agricultural productivity and expanding cultivation. The average budget of a ryot was 'not extravagant', but allowed him a modicum of reserve income for nonfood expenditures such as education, medical expenses and tobacco (Pillai 1929). Even with a low income, this report noted, 'the agricultural family is better off than a non-agricultural family with the same or higher income'.

The high dependence of Travancore's peasants on cash crops, however, rendered them vulnerable to market fluctuations, which made for precarious living, particularly during and after the Great Depression of 1929. Most of Travancore's peasants cultivated coconuts in small-sized holdings of garden land. By 1931-32, the cultivation of coconuts, which fed the cottage industries in coir products, covered nearly 665,000 acres. Small cultivators also began to take advantage of the rise in rubber prices around 1920. By 1935 their holdings covered 37.8 per cent of the total cultivated area (ibid.: 8). No figures are

Table 2.1 Crops and area under cultivation in Travancore, 1920-30

\begin{tabular}{lrrr}
\hline & \multicolumn{1}{c}{ Acres } & \multicolumn{1}{c}{ Acres } & \% increase \\
\hline Net area sown & $2,008,960$ & $2,201,295$ & 9.6 \\
Paddy & 648,609 & 665,087 & 2.5 \\
Tapioca & 404,092 & 480,589 & 18.9 \\
Coconut & 455,970 & 563,048 & 23.5 \\
Rubber & 51,018 & 61,986 & 21.5 \\
Tea & 47,105 & 74,616 & 58.4 \\
\hline
\end{tabular}

Source: Report on the Census of Travancore 1931, Part 1. 
available for the area under cultivation in 1860; however, it has been calculated that the area under cultivation in the period from 1821 to 1911 grew by 166 per cent. This figure does not include the area brought under cultivation by modern tea, coffee and rubber plantations, which rapidly expanded between 1920-21 and 1930-31. Most of the increased area under cultivation had previously been forest or wasteland, which was now converted into garden lands for growing cash crops (Uma Devi 1989: 59).

The effect of the land reforms on the agrarian economy, as the figures in Table 2.1 show, was to expand the area under cash crops at the expense of the cultivation of food crops. Although the population grew by 27.2 per cent between 1920-21 and 1930-31, the net area sown only grew by 9.6 per cent. Most of this increase was in tea, coconut and rubber, rather than tapioca and paddy (rice). As a result, Travancore began to import paddy from Burma to make up for the deficiency in its local production (ibid.).

In addition to the state policy of encouraging the expansion of cultivation, the favourable tax policies of the state, and better infrastructure compared with Malabar, encouraged British plantation companies and small capitalists to invest in Travancore. Kannan (1988) has identified three main types of production regimes that were introduced in Travancore by the late nineteenth century. These were 'large-scale capitalist production with marginally superior technology', in the form of coir production (made from coconut fibre), tea and coffee plantations, tile manufacturing and cashew processing; 'small-scale capitalist production', such as beedi-making (locally produced cigarettes), toddy-tapping (alcohol tapped from a tree) and coir processing; and finally, artisanal, household production such as handloom weaving and rice pounding. The scale of capital investment in Travancore in the first large-scale capitalist production sector can be discerned through figures on the plantation industry alone. The number of registered plantation companies grew from three in 1905 and to 108 by 1945 (Varghese 1970: 117). The coir industry was another crucial area of growth and employment, although it was primarily concentrated in the coastal towns of southern Travancore, namely Alleppey and Shertallai: in 1900 there were six coir factories, which grew to twenty-two in 1921 (ibid.: 55-56). What is notable is the low level of technological development in the most commercially developed part of Kerala, a factor which did not change much in the post-independence years.

Malabar and Travancore represent two polar ends of a continuum in which the three areas of Kerala (and the rest of British India) were brought under the sway of colonial rule and colonial capital. Although all three regions experienced rapid proletarianization, Malabar saw a rise in 'excessive' landlordism, while in Travancore the princely state all but abolished large, feudal landlords, and ushered in land reforms 'from above'. The smaller princely state of Cochin falls in between these two polar ends. The Cochin monarchy was weaker than that of Travancore, and had to contend with a more powerful landlord class. The 60 per cent of the total land that was owned by landlords was in the hands of powerful Namboodiri families, temples and families of chieftains, and those connected 
with the Royal Palace (Varghese 1970: 48). The state was thus unwilling to meddle in landlord-tenant relations. When urged by the Resident to implement similar legislation to that in Travancore, the Dewan refused, suggesting in a memorandum that was welcomed by the landlords, that such legislation was unnecessary and unfeasible (Menon 1970: 63). Consequently, the agrarian structure that emerged from 'indirect rule' in Cochin was different from Travancore's and somewhat closer to that found in Malabar, with 60 per cent of land owned by landlords and 40 per cent under state ownership (Varghese 1970: 48). State revenue was much higher on state-owned lands (double the rate of Travancore and roughly one-and-a half-times that of Malabar) (ibid.: 49). The proportion of agricultural labourers to the total agricultural population in Cochin also grew to be higher than that of tenants. Commercial penetration of agriculture in Cochin was not as extensive as in Travancore or Malabar (in Travancore cash crops occupied roughly 46 per cent of the total cropped area in 1930-31, in Malabar roughly 34 per cent and in Cochin 26 per cent). However, Cochin had a significant non-agricultural labour force - roughly 22 per cent compared with 16 per cent in Malabar (Census of India 1951).

A comparison of the agrarian structures that had developed in Malabar, Cochin and Travancore by 1931 reveals the sharp contrasts among them.

Table 2.2 shows the much higher incidence of tenancy in Malabar compared with the higher incidence of peasant proprietorship in Travancore. While Malabar also had a much higher percentage of agricultural labourers, the figures in Travancore are somewhat understated because they were counted as domestic servants before 1931. The existence of a somewhat large segment of agricultural labourers in Travancore appears odd considering the high proportions of smallholding peasants who mostly cultivated lands with their own family labour

Table 2.2 Distribution of agricultural population in Travancore (T), Cochin (C) and Malabar (M): 1901-31 (per 100)

\begin{tabular}{llllll}
\hline Class & & 1901 & 1911 & 1921 & 1931 \\
\hline $\begin{array}{l}\text { Cultivating and non-cultivating } \\
\text { landowners }\end{array}$ & & & & & \\
& $\mathrm{T}$ & 70 & 69 & 69 & 61 \\
& $\mathrm{C}$ & 4 & 10 & 9 & 19 \\
Tenants & $\mathrm{M}$ & 5 & 4 & 4 & 6 \\
& $\mathrm{~T}$ & 6 & 6 & 10 & 6 \\
& $\mathrm{C}$ & 35 & 34 & 35 & 21 \\
Agricultural labourers & $\mathrm{M}$ & 34 & 34 & 35 & 23 \\
& & & & & \\
& $\mathrm{~T}$ & 20 & 21 & 18 & 31 \\
& $\mathrm{C}$ & 60 & 54 & 50 & 56 \\
& $\mathrm{M}$ & 61 & 60 & 58 & 68 \\
\hline
\end{tabular}

Source: Adapted from Kannan 1988: 46. 
(a direct consequence of the land reforms). This factor can be explained by the caste restrictions on manual labour that existed in early twentieth-century Travancore.

As the 1931 Census of Travancore noted:

The majority of the agricultural holdings in Travancore ... are so small that the cultivators can attend to the farming operations themselves without the help of hired labour. But the Travancore cultivator, though his holding may only be a few cents, is, as a result, a gentleman farmer. He does not like to soil his hand by handling a plough ... that is why we find here a large[r] number of agricultural labourers than the smallness of the size of the majority of the holdings warrants.

Although caste-based restrictions on manual labour independently affected the composition of the agricultural population, smallholders had another reason to turn towards agricultural labour to supplement their household incomes. A rise in population had resulted in the near exhaustion of land. The rise in the man-land ratio and the increasing subdivision of agricultural holdings meant that more and more cultivators needed to supplement their earnings through agricultural labour (Jose 1980: 5). The 1931 Census of Travancore noted that 'if 10 acres is considered to be the minimum size of an economic holding, only less than five per cent of the holdings fall within this category' (Census of Travancore 1931, Part I, Report). Indeed, in the lowland areas, the average size of a peasant holding was between 1.4 and 3.8 acres, while in the lower upland areas, it was roughly 4.8 acres (Pillai 1929). Between 1921 and 1931 agricultural labour grew by 17 per cent (Census of Travancore 1931).

A crucial area of absorption of labour was the large influx of colonial capital, which had created better paying, even if more exploitative, jobs in town factories. There was now a large and growing non-agricultural labour force that found opportunities in the rapidly growing plantation sector, coir manufacturing and the numerous food processing factories that were set up during this period. The number of workers employed in these various industries was growing rapidly in Travancore, with the highest proportion occurring in the plantations. From 1911 to 1921 Travancore had the highest percentage of workers employed in the textiles industry (primarily in coir manufacturing) among the three regions of colonial Kerala, but the sharp drop that occurred from 1921 to 1931 was largely because of the Depression and the consequent halt in coir exports (for example, coir mats).

\section{Internal comparisons in social structure}

Below is a summary of the contrasting structural transformations that occurred in Malabar and Travancore. This shows the contrasting bases for peasant radicalism that emerged in these two parts of Kerala, such that communists perforce needed 
a strategy that drew together peasant proprietors, tenants and agricultural labourers. As subsequent chapters will discuss, this strategy also had to confront the caste issue, in part because of the deep politicization of caste among tenants in Malabar, and an emerging lower caste agrarian yeomanry in Travancore, and in part because it was a unifying issue among different classes.

1 In Malabar, a sharp caste-class divide between tenants and landords provided a ready basis for tenant rebellions. The state's strengthening of landlord power increased this potential. However, the evidence shows that neither this divide nor the sharecropping relations of production provided an easy basis for solidarity. This was mediated by religion wherein Muslim tenants rebelled more or less 'autonomously' of any political organization, whereas Hindu tenants were only politicized later through the issue of caste.

2 In Travancore, the colonial state and the semi-autonomous princely state weakened the power of landlords, and strengthened the tenants. This reversal of the Malabar policy produced a class of peasant proprietors and an emergent small manufacturing bourgeoisie. Ownership of land was diffused among different castes, such that the caste-class relationship was broken up. Caste was deeply politicized in Travancore, but through caste associations rather than the communists. An emergent proletariat in the new industries and agricultural sector formed a larger base for the communists than did the former tenants.

If an internal comparative analysis reveals the different bases of potential communist ascendancy, and introduces the importance of caste and religion in creating solidarities, how does Kerala compare with other Indian states in the colonial era? Tables 2.3 and 2.4 examine the degree of proletarianization in Kerala compared with other Indian states.

The evidence certainly suggests that both Kerala and Bengal (to be discussed) were more favourable venues for left party ascendancy, in particular, for a left strategy of uniting workers and peasants (which was eventually what the CSP attempted), than were Rajasthan, Uttar Pradesh, Assam and Punjab, for instance. Undoubtedly, the near proletarianization of the tenants-at-will in Malabar, and agricultural and industrial proletarianization in Travancore and Cochin, was more marked than in other parts of British India. ${ }^{21}$

We have to once again confront the clear relationship between rates of proletarianization and actual communist ascendancy. The evidence shows this is the most robust relationship compared to variables proposed by Paige, Zagoria or Wolf. In Chapter 4 I will show how communists filtered the peasants' and workers' experience of proletarianization through a new language of class confrontation by first appropriating the language of caste protest that had already taken hold, in particular, in Travancore. 
Table 2.3 Rates of proletarianization by state, and the 'proletarianization index', $1911-51^{1}$

\begin{tabular}{|c|c|c|c|c|c|c|c|c|}
\hline & \multicolumn{2}{|c|}{ Proletariat $^{2}$} & \multicolumn{2}{|c|}{ Cultivators } & \multicolumn{2}{|c|}{$\begin{array}{c}\text { Ratio of proletaria } \\
\text { to cultivators }\end{array}$} & \multirow{2}{*}{$\begin{array}{l}t P R \\
1911 \\
-51^{3}\end{array}$} & \multirow{2}{*}{$\begin{array}{c}P I \\
1951^{4}\end{array}$} \\
\hline & 1911 & 1951 & 1911 & 1951 & 1911 & 1951 & & \\
\hline Andhra Pradesh & 37.6 & 39.4 & 41.3 & 41.3 & 0.91 & 0.95 & 4.4 & 0.95 \\
\hline Assam & 21.8 & 19.0 & 67.6 & 61.6 & 0.32 & 0.30 & -0.30 & 0.30 \\
\hline Bihar & 29.7 & 30.2 & 58.5 & 60.3 & 0.50 & 0.50 & 0 & 0.50 \\
\hline Gujarat & 38.1 & 28.3 & 39.8 & 45.3 & 0.95 & 0.62 & -0.34 & 0.62 \\
\hline Kerala & 48.6 & 48.1 & 31.5 & 25.6 & 1.54 & 1.86 & 20.8 & 1.87 \\
\hline Madhya Pradesh & 35.7 & 31.8 & 48.9 & 54.0 & 0.73 & 0.70 & -0.04 & 0.58 \\
\hline Madras & 27.7 & 23.9 & 51.0 & 40.9 & 0.54 & 0.58 & 0.07 & 0.58 \\
\hline Maharashtra & 26.6 & 38.1 & 39.5 & 39.4 & 0.67 & 0.96 & 43 & 0.96 \\
\hline Mysore & 31.1 & 28.7 & 50.8 & 52.4 & 0.61 & 0.54 & -1.14 & 0.54 \\
\hline Orissa & 32.3 & 28.3 & 55.5 & 58.0 & 0.58 & 0.48 & -17.2 & 0.48 \\
\hline Punjab & 25.1 & 21.3 & 52.5 & 54.2 & 0.47 & 0.39 & -0.17 & 0.39 \\
\hline Rajasthan & 22.0 & 18.1 & 53.8 & 64.6 & 0.40 & 0.28 & -0.3 & 0.28 \\
\hline Uttar Pradesh & 22.5 & 19.0 & 61.3 & 65.3 & 0.36 & 0.29 & -0.19 & 0.29 \\
\hline West Bengal & 35.1 & 36.2 & 45.8 & 36.3 & 0.76 & 0.99 & 31 & 0.99 \\
\hline
\end{tabular}

1 Figures calculated from Census of India, 1961, Paper I, 1967, in Cambridge History of India, Vol. II, p. 542. Figures are percentages of total population.

2 The category of 'proletariat' includes agricultural labourers, workers employed in plantations, forestry, mining and quarrying, and manufacturing.

$3 \mathrm{PR}=$ Proletarianization rate. This figure was calculated by subtracting the ratio of proletariat to cultivators $(\mathrm{P} / \mathrm{C})$ in 1911 from the figure for 1951 and dividing by the figure for 1911 .

$4 \mathrm{PI}=$ Proletarianization index. This figure calculates the ratio of proletariat to cultivators to capture the degree of proletarianization in 1951 in each state.

Table 2.4 Proletarianization rate in British India between 1911 and 1951

\begin{tabular}{lccc}
\hline Region & $P R$ & $\%$ AL & $\%$ WKRS \\
& $1911-51$ & 1911 & 1911 \\
\hline Kerala & 21 & 25 & 49 \\
Bengal & 31 & 17 & 39 \\
Bombay & 15 & 25 & 35 \\
Bihar and Orissa & 0 & 21 & 20 \\
United Provinces & -0.17 & 72 & 25 \\
Punjab & -0.19 & & \\
PR = Proletarianization rate (between 1911 and 1951) from Table 2.3. \\
AL = Agricultural labourers & & \\
WKRS = Industrial workers, including those employed in plantations, manufacturing, the service \\
sector, transport, and industrial sectors classified as 'other'. \\
\hline
\end{tabular}

Sources: Adapted from table in Patel 1992: 66. Figures for Kerala taken from Kannan 1988.

Note: In the landlord-dominated (zamindari) areas, agricultural labourers were mostly 'dwarfholding' sharecroppers and tenants-at-will. A 'dwarf-holder' cultivated less than 5 acres of land, and his status approached 'much more closely ... that of a labourer than an independent cultivator' (Royal Commission on Agriculture, 1928 cited in Patel 1992). 


\section{'Objective conditions' and the potential for radicalism in late colonial Bengal}

The entire region of Bengal came under direct British rule, unlike the princely states of Travancore and Cochin in Kerala. In Bengal, the British enacted the Permanent Settlement in 1793, which as in Malabar, granted revenue collectors from the Mughal era the title of 'landlords' with full proprietorship rights. As Ranajit Guha (1996: 93) notes, the Permanent Settlement was not merely an effort to restructure land policy, but had a large 'moral' component that was designed to address finance, taxation, trade and the problem of British rule in general. Philip Francis, the architect of this policy, was influenced by the French physiocrats, and searched for the equivalent to the English gentleman-farmer in Bengal. He located this figure in the zamindar, the hereditary revenue-collector from the Mughal era. As Guha and other scholars of Bengal suggest, this was a curiously misguided view of traditional property relations and of the potential for generating a market in land and private property based political economy. Instead, it was the dominant landed village groups that had effective possession of the land and commanded the labour of sharecroppers and hired labourers (Ray and Ray 1971: 216). In many regions of Bengal, particularly those in the easts, the predominant form of tenure was the small peasant family farm, cultivated by family labour. Here, the British were anxious to preserve the peasant's right to the land as far as possible - in part to ensure the peace, and in part to encourage the growth of commercial crops in the period of growing international trade (Chatterjee 1984: 7). In effect, two sets of rights in the land were recognized by the state - the right of proprietorship and the right of occupancy.

The growth of trade in rice and jute had the effect of encouraging extensive rent exploitation and sub-infeudation based on rights of occupancy. Jute was a popular crop because peasants could get advances when their food stocks from rice harvests were low, but the market in jute fluctuated tremendously, and peasants could never rise above subsistence level (ibid.: 9). The zamindars, forced by the state's high revenue demands, farmed out jungle lands and other cultivable wastelands on tenurial leases to a class of 'enterprising men' who then cleared the land and settled it with tenant-cultivators. As cultivated area and rent increased over the mid-nineteenth century, a gap arose between the fixed land revenue and rent that could be extracted from the actual cultivators. In turn this gap in revenues spawned a huge increase in rentier interests. It was estimated in 1918-19 that proprietors and intermediate tenure-holders took as much as 76.7 per cent of the gross rental, paying the rest as land revenue (ibid.: 11). The resulting structure of interests at the top of the agrarian structure consisted of a few wealthy zamindars, followed by numerous estates below that were held by 'petty proprietors-tenureholders-cum-professionals', also known as the bhadralok.

A similar process of fragmentation and differentiation of rights took place at the level of land occupation. Increasing population growth at the turn of the twentieth century and rising demand for land led to this process of sub- 
infeudation, and the rise of numerous intermediaries who sought a larger share of rent. The pressure on land was exacerbated by the absence of rural industries and industrial growth. As a result of the codification of different rights under the tenancy reforms of 1885, for example legal rights against eviction and against the enhancement of rents, the subletting and mortgaging of raiyati or occupational interests became common practice. In particular, a substantial 'rich peasant' or 'kulak' class arose in Bengal (as it did in the rest of India in the aftermath of the price increases of the 1860s (Stokes 1976: 100)). This class of peasants, also known as jotedars, made rapid profits from the rise in prices of cash crops such as jute, cotton, wheat, sugar and tobacco. By the nineteenth century, the land tenure relations in Bengal had congealed along a few different lines: in north Bengal (which included the districts of Jalpaiguri, Dinajpur and Rangpur) the dominant divide was between rich farmers or jotedars, and labourers, drawn primarily from semi-tribal groups (known as adhiars). The jotedars had reclaimed uncultivated land during the nineteenth century, and employed tribal groups from neighbouring regions to cultivate the land. The jotedars dominated the produce market, made decisions about production and extracted a large proportion of the produce as share rent and loan interest (Bose 1986: 15). In many parts of northern Bengal, adhiars were completely landless and serf-like. In western and central Bengal (which included the districts of Midnapore, Arambagh, Hooghly, Bankura, Burdwan and 24-Parganas), the land tenure relations consisted of a 'smallholding demesne labour' complex in which bhadralok or 'gentlemen' absentee farmers held villages surrounded by peasant sharecroppers. In east Bengal (which included the districts of Dacca, Tippera, Noakhali, Mymensingh), the dominant form of landholding was smallholding, where the typical unit was the small family farm.

Table 2.5 shows the comparative agrarian structures that had developed in the regional zones of Kerala and Bengal by 1931 .

Table 2.5 Comparative agrarian structures in colonial Bengal and Kerala, 1931

\begin{tabular}{lcccc}
\hline Region & $\begin{array}{c}\text { Non-cultivating } \\
\text { owners }\end{array}$ & $\begin{array}{c}\text { Owner- } \\
\text { cultivators }\end{array}$ & Tenants & $\begin{array}{c}\text { Agricultural } \\
\text { labourers }\end{array}$ \\
\hline Kerala & & & & \\
Malabar & 2.18 & 6 & 23 & 68 \\
Travancore & - & 61 & 6 & 31 \\
Cochin & - & 19 & 21 & 56 \\
Bengal & & & & \\
South and South-West Bengal & 9.4 & 41.5 & 8.4 & 40 \\
North Bengal & 7.7 & 48 & 14 & 29.4 \\
East Bengal & 7.9 & 65 & 6.1 & 20 \\
\hline
\end{tabular}

Sources: Figures for Kerala taken from Kannan (1988) and Jeffrey (1978: 135). Figures for Bengal calculated from Chatterjee (1984: 39). 
As the table shows, the percentage of owner-cultivators was clearly far more sizeable in Bengal than in Kerala, except for Travancore. The percentage of the total agricultural population in Kerala that existed in Travancore was 48 per cent, and thus the percentage of owner-cultivators found in Travancore was 29.2 per cent of the entire agricultural population in Kerala. Indeed, the majority of agricultural land in Bengal was in the direct possession of the owner-cultivator or raiyat. But these figures can only reveal broad categories of agricultural occupation, and do not tell us much about the different categories or gradations of raiyati or occupancy rights that existed in the land. While in Travancore owner-cultivators were granted full ownership rights by the princely state in the nineteenth century land reforms, the flip-side to the increase in superior rights over land in Bengal was the considerable depeasantization that occurred over the course of the twentieth century. Sharecropping or bargadari became the preferred mode of cultivation for landowners during the late nineteenth and early twentieth centuries as they became interested in securing a share of the produce with the expansion of the market in jute and rice (Dhanagare 1983: 158).

Depeasantization was particularly exacerbated by two conditions: the Depression of the early 1930s, and rising population. When crop prices dropped sharply during the Depression, the flow of money credit stopped and numerous peasant smallholders found themselves heavily in debt, unable to bear the costs of rent and labour. Landlords and rich farmers purchased their land, and numerous peasants were proletarianized in the process (Bose 1986: 167-70). This trend was particularly acute in west and central Bengal where the landholding structure 'tended to sag in the middle, and was reinforced at the extremities by the extension of khamar (personal demesne of landlords) and a land poor, if not wholly landless, rural work force' (ibid.). Often if the peasants were not evicted outright as they were in Malabar, they continued to cultivate the land with inferior rights and higher rents (see Chatterjee 1984: 36-60).

The regional complexes of land tenure relations in colonial Bengal gave rise to a highly varied potential for agrarian radicalism. In the northern regions of Bengal, the potential for radicalism among adhiars was acute because they constituted a near landless labour force in opposition to the landholding jotedars. In the west and south-western regions of Bengal, the increase in sharecropping, depeasantization and proletarianization during the 1930s created a new potential for agrarian radicalism against both zamindars and jotedars. The potential for anti-landlordism was high among the peasantry (much like in south Malabar among the Moplahs), but class consciousness could just as easily be (and was) directed towards communal conflict between Hindus and Muslims. In the eastern regions of Bengal, the smallholding peasant communities were cemented by religious homogeneity, as most peasants were Muslims and landlords were Hindus - this also contributed to the religious tensions in the region which turned particularly violent during 1946-47. This factor will be discussed at greater length subsequently in the book, as religious violence in the aftermath of the 
Partition formed a crucial basis for the ascendancy of the communists, whose relief work among the peasants established them as a serious political force.

This broad sketch of agrarian relations in colonial Bengal appears to point towards a considerable potential for peasant radicalism - a potential that was realized in fits and starts through the 1920s and 1930s, often well after the structural changes had occurred. In comparison with Kerala, it appears that the prevalence of sharecropping was at least as widespread and, moreover, that peasant settlement was in the traditional 'village' mode rather than scattered settlements which increased the possibilities for rebellion. Moreover, the caste structure in Bengal was not as hierarchical as in Kerala, and thus was not prohibitive of collective action among peasants. Not surprisingly, therefore, there were independent instances of anti-jotedar and anti-zamindar protests by sharecroppers in the west and north of Bengal during the 1920s and 1930s, that in fact predate the entry of left wing parties and radical leadership (see Cooper 1988; Das Gupta 1992; Sanyal 1979). This early agrarian radicalism did not exist in Kerala, which is ironic given that the communists in Kerala gained ascendancy earlier than in Bengal.

In brief, the enormous variation in the potential for agrarian radicalism within and between the regions of Kerala and Bengal make it difficult to posit a straightforward relationship between the bases of radicalism and eventual political outcomes. Clearly, both regions contained the kinds of class tensions that give rise to radical left regimes, especially the split between a land-controlling landlord class and a near proletariat. However, this class divide was not uniformly present, and it is clear that political organizers would need to employ a cross-class strategy that tapped into caste relations in Kerala, and the important issue of worker-tenant alliances in both regions. 


\title{
3 State formation and social movements
}

\author{
Colonial Kerala and Bengal \\ compared, $1865-1930$
}

Until now I have emphasized the importance of colonial political economy as the terrain upon which subsequent political formations in British India arose. But in speaking of the state, or more precisely what Mahmood Mamdani (1996) has called the 'mode of administration' we must consider how British strategies of rule and domination affected politicization among various castes and classes. Even if ultimately political party organizations, their social bases and modes of ascendancy created new areas of reform that transformed the social structures of post-independence India, colonial legacies were equally critical in defining whether and how this transformation occurred. Thus, as this chapter shows, farreaching colonial-era welfare reforms in Kerala's princely states left behind a distinct legacy for future reforms in the region. It shows more generally that patterns of state formation and welfare leave distinctive policy legacies; although they do not simply provide replicable blueprints, we can think of them as toolkits for future strategies of state action that may involve very different political actors.

The princely states of Travancore and Cochin, which constituted the bulk of what is now modern Kerala undertook comprehensive reforms in education, public health and social issues such as untouchability, during the mid-nineteenth to early twentieth centuries. These reforms were carried out within the ambit of the indirect colonial state and, equally important, Christian missionary influence. The impetus for such reforms initially came 'from above' and only later as the result of demands from lower castes themselves. These reforms not only raised the demographic and welfare profile of sections of Kerala's lower castes, but bequeathed legacies of state action that were peculiar to Kerala.

It is of crucial importance to point out that lower caste self-organization eventually formed the primary link between the reforms of the nineteenth and twentieth centuries in Travancore and Cochin. They contributed to a model of popular demands in conjunction with a state that was willing, and possessed the capacity, to reform. Of course, the willingness and capacity of the indirectly ruled states was largely limited and informed by their upper caste bias, and a concern with stability, while that of the left-ruled state of post-independence Kerala was concerned with maintaining and building its hegemony through a social 
democratic transformation. The latter state, however, built upon the incipient bourgeois revolution begun during the nineteenth century, and attempted to extend it within certain limiting conditions that can be traced back to nineteenthcentury economic patterns. The critical beginning of this pattern of development began with the disarticulation of the land market from caste restrictions as discussed in Chapter 2. As a result, those on the bottom rungs, particularly the Ezhavas, began to demand social and political citizenship rights from the Travancore and Cochin states. These demands were spurred on in the context of another critical feature of Kerala's distinctiveness, namely, a rise in the number of intermediary caste associations, which eventually provided some of the generative conditions for communist ascendancy. These associations - whether caste or mission-based - do not, however, conform to the purely western classical conception of civil society. They were often loyal to the state, and even extensions of it - and the analysis that follows shows how complex this legacy proved to be for the communists.

The analysis of state formation and its effects on social policy in Kerala must also examine an important aspect of the colonial experience, namely, Christian missionary intervention in the areas of education and social reform. The unique confluence between a modernizing monarchy under indirect British rule, and the ideological and practical activities of Christian missionaries, forms an extraordinary backdrop to the rise of the communist party in the region. While it is widely acknowledged that Christian missionaries were closely tied to the colonial project and sought to buttress the ideology and structures of colonialism, missionary activity was not an undifferentiated enterprise. For, replete with the racist and evangelizing spirit of conversion, missionaries ironically found themselves working among the poorest and most downtrodden in the colonies (Comaroff and Comaroff 1991; Kooiman 1989). It was the despised and marginalized who most sought after the activities and resources provided by the missions, and flocked to convert to Christianity. Thus missionaries came to occupy a liminal position between the colonial state and local social hierarchies and power structures, campaigning for reforms of social practices that colonial officials were consciously or unconsciously abetting (Cox 2002).

The majority of missionaries were not simply wandering preachers, but established their presence by building institutions like churches, schools and hospitals, which had enduring effects upon state-building (Kawashima 1998: 7). In princely Kerala, the effects of missionaries on the rise of state welfarism involved three dimensions: (1) the actual services provided by missionaries, to the lower castes in particular; (2) the effects of mass conversions to Christianity upon the monarchy and upper caste populations; and (3) the rise in consciousness among non-convert lower castes, that is, Christianity offered an alternative world-view, as well as the possibility of exit from the caste system. Missionaries found a hospitable environment, in part because of pressure from British officials. The first missionary in Travancore, William Ringeltaube, received a land grant from Queen Victoria upon the recommendation of Resident Col. Munro, and 
claimed that ' $[\mathrm{t}]$ his grant firmly establishes the Protestant religion in Travancore as long as the British flag shall continue to fly' (Yesudas 1980: 5).

The institution-building effects of missionary activity in Kerala involved the opening of missionary schools on a fairly large scale. The pioneer in this area was the London Missionary Society (LMS), which set up schools that were also meant to serve as congregations (Kooiman 1989: 88). In 1830 there were 100 LMS schools, which had tripled by 1860 , with approximately 14,000 students (ibid.: 89). Most of the students came from poor and untouchable families, whose educational needs had been largely ignored by the state. However, rising financial difficulties and the unaffordability of new schools despite rising demand led the LMS missionaries to petition for government support. The result was grants-inaid provided by the Travancore government in return for government supervision of education. A small benefit for the government, no doubt, was the fact that untouchables would possess their own schools and not 'pollute' schools run by the government for the upper castes (ibid.). But we still have to explain this extraordinary action on the part of the state.

Pressure from missionaries had brought the Travancore government to open its first schools as early as 1850 . Government expenditure on schools grew from 1.4 per cent of gross expenditure in 1864-65 to 3.5 per cent in 1877-78 (Kawashima 1998: 90). Schools imparted both vernacular and English education, so there appears to have been some attempt to expand its scope to the masses. Yet the lower caste Izhavas, Pulayas and Parayas were largely excluded from government schools through subtle forms of discrimination. In 1891-92 Izhavas were only 2.1 per cent of all pupils in government schools, while they constituted 16 per cent of the population (ibid.: 107). It was only after repeated protests by Izhavas that an Education Code was introduced in 1909-10. Apart from comprehensive measures for regulating education by reclassifying schools into primary and secondary schools, the code introduced a system of licensing teachers and modernized the curriculum. The most important aspect of the Education Code was to recognize the importance of opening all schools to all classes 'without distinction of class or creed' (ibid.: 110). Gradually, communities classified as 'backward classes' were given full fee concessions, while other poor students were given half fee concessions. The Travancore government gave aid to night schools so that 'poor agricultural laborers whose work occupies the whole of their day-time,' could attend school (Pillai 1941). Table 3.1 shows the steady and rapid growth in state expenditure on education in Travancore. But Table 3.2 shows that Travancore's expenditure, although the highest among the princely states and Madras, does not stand out as a clear outlier.

To explain the comparatively higher rates of literacy that emerged from the state's efforts in Travancore involves taking into account the synergy that existed between state modernization and missionary attempts, as well as the consistent demand for education from the lower castes that was peculiar to this region (a very similar process occurred in Cochin, but since Travancore was the larger of the two the discussion mainly focuses on this princely state). This triage of social 
Table 3.1 Percentage of gross expenditure on education to total expenditure of the Travancore state, 1874-1945

\begin{tabular}{lc}
\hline Year & \% spent on education \\
\hline $1874-75$ & 2.8 \\
$1884-85$ & 3.3 \\
$1894-95$ & 4.7 \\
$1904-05$ & 6.2 \\
$1914-15$ & 11.4 \\
$1924-25$ & 14.6 \\
$1934-35$ & 20.4 \\
$1944-45$ & 16.2 \\
\hline
\end{tabular}

Source: Adapted from Singh 1944.

Table 3.2 Comparison of growth in state expenditures on education across British Indian and princely states, $1879-1942$

\begin{tabular}{|c|c|c|c|c|c|}
\hline $\begin{array}{c}\text { Cochin } \\
\text { (1879-80 to } \\
1939-40)\end{array}$ & $\begin{array}{c}\text { Mysore } \\
(1911-12 \text { to } \\
1940-41)\end{array}$ & $\begin{array}{c}\text { Hyderabad } \\
\text { (1913-14 to } \\
1938-39)\end{array}$ & $\begin{array}{c}\text { Baroda } \\
\text { (1904-05 to } \\
\text { 1939-40) }\end{array}$ & $\begin{array}{c}\text { Madras } \\
(1910-11 \text { to } \\
1940-41)\end{array}$ & $\begin{array}{c}\text { Travancore } \\
\text { (1900-01 to } \\
1941-42)\end{array}$ \\
\hline \multicolumn{6}{|c|}{$\%$ expenditure on education to total expenditure } \\
\hline 2.1 & 4.9 & 2.2 & 4.6 & 5.4 & 5.5 \\
\hline 18.5 & 10.2 & 11.1 & 15.7 & 15.8 & 16.2 \\
\hline
\end{tabular}

Source: Adapted from Singh 1944.

forces is the key to explaining the particular model of welfarism that developed in Kerala during the nineteenth century (under the communists this model had different implications especially as concerned the state's strategy of rule and modernization). The Travancore monarchy, unwilling to break caste taboos to educate lower castes, clearly needed missionary schools to meet the demand for education from the lower castes. On the other hand, the state was under considerable negative pressure from upper caste groups, for they viewed missionary schools as venues for the conversion of lower castes to Christianity. Ironically, fearing the demise of their claims to caste superiority and seeing the missionaries as their enemy, they began to urge the Travancore state to open up government schools to the lower castes. State officials began to recognize that a secular growth in the Christian population through conversions threatened the homogeneity and thus the stability of Travancore. A vocal and restive Christian population among the lower castes also threatened to unsettle the upper castebased regime of Travancore; the feeling of being besieged by other religious communities was spreading among Hindus across British India at the time. The 
Education Code that was implemented as a result imposed greater state control over education with the intention of curbing missionary influence.

Certainly, then, there was considerable pressure generated on the state by the missionaries, and by the threat of conversions in a largely Hindu polity. Yet a comparative glance at missionary activity in other regions of India such as Bengal and Madras suggests that an adequate account of the state reforms in Travancore must account for the state's porosity to missionary demands, that is, its willingness to implement reforms, however grudgingly. In Bengal and Madras, Baptist and Methodist missionaries, some belonging to the LMS, took up similar projects of education and struggled on behalf of the Parayas and untouchables, as well as other lower castes, against various forms of discrimination. In Bengal, missionaries also took up the cause of tenancy reforms, which brought them into direct conflict with the landlords or zamindars. Lower caste converts to Christianity were often threatened, intimidated, and ostracized by landlords (Oddie 1979). In the Trichy-Tanjore area of Madras, Paraya converts to Christianity found themselves persecuted by landowners, and denied work and traditional communal privileges (Manickam 1977: 83). The colonial administration was also more hostile towards the missionaries, particularly with regards to providing them financial support to run schools (ibid.: 131). This was in marked contrast to the missionaries' reception in southern Kerala. While in none of these cases did the upper caste Hindus express an interest in conversions, there does not appear to have been the same degree of hostility to lower castes choosing to do so. In fact, as Kooiman (1989) explains, plantation owners and landlords preferred Christian labour to the untouchables, for they were seen as more disciplined. How can the less intransigent stance of the Travancore state to reform of caste exclusion be explained?

One rationale for the Travancore state's yielding to lower caste protest might be that once modernizing reforms had been set in motion, largely through reforms of land tenure, rigid status-based distinctions were not a necessary part of the regime's stability. There were certainly fears, but these do not appear to have been based upon any real threat. Most of the lower caste Izhavas, for example, were simply interested in breaking caste barriers for the purpose of creating new avenues for entrepreneurship, or to own land and improve it. Unlike in Bengal and Madras, there were no intermediaries to block the modernizing aspirations of the lower castes, and eventually the monarchies of Travancore and later Cochin gave way to larger increments in caste citizenship with the opening of roads and temples to lower castes by the 1930s. These were not yielded without protest, but there was no serious challenge to the efforts of the lower castes either. Thus once the state had ceased to base its authority and legitimacy on the nexus between landlordism and upper caste domination, and extracted its resources primarily from trade and capitalist agriculture, the door was opened to increasing claims for the extension of citizenship to lower castes, as well as its deepening from economic to political and social citizenship. 
If caste protest urged reforms upon the Travancore state, there was also the rationale of pre-empting further escalation, which raises some analogies with the reforms pioneered by Bismarck in Prussia in the 1860s. However, while Bismarck's reforms were a pre-emptive measure against growing working class mobilization, in Travancore the reforms were a pre-emptive response to British proximity and the threat of annexation, as well as the threat of mass conversions to Christianity, which would have created a fairly serious glut on the Hindu population (or so it was perceived), and destabilized the polity. The caste protests were themselves not strong enough to destabilize the monarchy; rather, their modalities and tactics of protest and demands were rather easily accommodated and absorbed. An obvious response was simply to modernize aspects of an archaic caste system; as Jeffrey (1976: 70) notes, the 'goal of the reforming sirkar (government) was to lift the whole of Travancore society a few notches on some abstract scale of civilization - without altering the relative position of the various groups.' Or, as an observer commented:

The arguments that were used in the middle of the last century in support of a scheme of popular education were different from the arguments which are now impressing the public mind. In the days of Lord Macaulay popular education was defended in the interests of the governing class. It was urged that if the task of the government were to be safely accomplished, if the prisons were to be emptied of criminals, if intemperance were to be reduced, if the dangerous fevers of dangerous unrest were to be assuaged, these objects could only be effected by means of a State system of education. I do not dispute the cogency of these arguments. They are all as true as they were in 1850 or 1870 , but they are not the only or the main ground upon which we found our belief in the good of education ... We believe in education as an end in itself; we do not think it should be restricted to any class or section of the community. We believe it enables men and women to escape from the oppression of a difficult and sometimes sordid life into regions of pure employment, that it dispels clouds of class suspicion.

(Aiyer 1998)

The Travancore state's reforms had the dual effect of modernizing while retaining the status hierarchies that formed the basis of its legitimacy and power; the characterization of 'enlightened benevolence' that is often used (surprisingly by Amartya Sen (1991)) to refer to the Travancore state is rather partial and neglects the larger aims of the state in implementing these policies. In comparative perspective, of course, the near absence of any such social policy measures by other princely states (for example the despotic regime of the Nizam of Hyderabad) or indeed by the British themselves, marks Travancore as rather different - and undoubtedly an important precursor to state reforms in later decades when considered comparatively. 


\section{The growth of an incipient bourgeois state}

As with the policies concerning the expansion of education, Travancore's activism on the public health and literacy fronts almost certainly also have something to do with the timing of British injunctions and influence, coming as they did with the ryotwari policy in land tenure. While on the one hand the state encouraged a laissez-faire policy of freeing up land from landlord control, and promoting private property in land, ironically, it matched the ideology of free trade and commerce with one that extended its own reach in society. The cascading reforms set in motion by the Travancore state resulted in the growth of what Michael Mann (1986) calls the 'infrastructural power' of the state, that is, the penetration of state power in civil society. This must be seen as a crucial historical legacy for future political struggles over welfare in Kerala, for the mode of state penetration pioneered during the nineteenth century formed the parameters for future citizenship struggles within a bourgeois state.

The modern state, as Weber argued, includes routine, formalized and rationalized institutions that hold sway over a larger territory and larger populations than pre-modern states. In British India, this extractive rationale undergirded the colonial enterprise, but the necessity of ensuring a steady source of revenue and land for setting up British plantations or commercial crops for trade prompted state formation and expansion in unforeseen ways. In fact, the extension and penetration of the state in civil society was ironically taking place while a minimal role for the state was being advocated in the economy. For example, in 1870, as Lord Macaulay was defending minimal state interference in free trade, he was arguing for the extension of the state's role in public health and education. These utilitarian-inspired notions of progress and individual and social improvement were mingled with fears of revolt from below. The idea was not simply to contain the poor, but to prevent the spread of their 'germs' and 'low morality', in which endeavour the state was seen as performing a duty as well as acting in self-interest. One reason was simply to guarantee a measure of security against growing volatility among 'the masses'; the British had to contend not only with a restive population (as they were reminded by the Great Indian Mutiny of 1857), but with growing demands for legislation and social reform from lower and middle castes. In encouraging and implementing social reforms, the British colonial officials felt part of a higher moral project, of vanquishing barbarism and bringing enlightenment to the masses. The abolition of slavery, interest in casteism and various social practices deemed by them to be backward, were, then, all grist for the colonial legislative mill. In turn, new legislations and reforms entailed an expansion in 'infrastructural power,' the 'institutional capacity of a state to penetrate its territories and logistically implement decisions' (Mann 1986: 59). As Mann argues, infrastructural power is " "power through" society, coordinating social life through state infrastructures.' Infrastructural power thus increases the power of the state in society, by structuring more of it, or 'caging' more social relations within its purview. The result is an oscillation between a more authoritarian inclination, dominating more of social life, but also an 
increase in the control of civil society over the state (ibid.: 61). It is apparent that both the increasing domination of the state over areas of social life, as well as the control of civil society over the state, were stronger in Kerala than in most parts of India. This accounts for why when leftists eventually came to power they controlled a state with a strong capacity to make a difference through welfare policies, which developed and extended through the decades as a result of social protests led by the left itself.

A crucial illustration of the increased 'infrastructural' penetration of the Travancore state is the public health measures that it undertook by the late nineteenth century.

In 1865 the Maharajah of Travancore declared:

One of the main objects of my ambition is to see that good medical aid is placed within the reach of all classes of my subjects. It is a blessing which it is not at present in the power of individuals generally to secure how much soever they may desire it. It is hence the obvious duty of the state to render its assistance in this direction. (my emphasis)

(Nagam Aiya 1966: 537)

Containing the myriad diseases that plagued its population and raising life expectancy required an expansion in the very capacity of the state - the collection of statistics, the administration of public health measures such as vaccinations, education on cleanliness and health, and the eradication of diseases. Before 1893-4 there was no concerted effort to collect reliable statistics, with most registers of births and deaths being kept by village officers. In that year the Towns Improvement and Conservancy Regulation II mandated the regular collection of statistics through committees appointed by the government. A special department organizing vaccinations, collection of statistics and sanitation was created and put in charge under a Sanitary Commissioner. The scheme was outlined as follows:

The department will be under the control of a professional officer styled Sanitary Commissioner, who will be in direct communication with the Government. For purposes of this Department, the whole country is divided into four districts [...] and an Inspector will be appointed to each district whose duty will be (1) to superintend and check the vital statistics throughout the district; (2) to attend to the sanitation of all parts of the district where the Towns Improvement Regulation is not in force; (3) to study and report on the state of public health within his district; (4) to superintend vaccination work; and (5) to be a sort of traveling dispensary, actually conveying medical aid to the door of the villager.

(Nagam Aiya 1966: 537)

The government's public health agencies put out pamphlets, and sent representatives to various corners of Travancore, often utilizing cinema houses 
for propagating their message. The higher literacy rates (compared with other provinces) certainly played a key role here, since considerable emphasis was placed on preventive medicine through public education. As a result of these measures death rates for adults and infants dropped sharply, and Kerala's pattern of deviation from other regions of India began as early as the 1930s (Table 3.3).

In much the same fashion the result of the Travancore state's education policies was that literacy rates rose rapidly in the state (similar initiatives were undertaken in Cochin, whose literacy rates also rose during the early twentieth century). Table 3.4 shows a comparison of literacy rates in some Indian princely states and British Indian provinces.

As the Census commissioner of 1931 noted, Cochin had more than 1 literate female to 2 males, Travancore somewhat fewer, Malabar nearly 1 to every 3 . Coorg fewer than 1 to every 3, Baroda a little less than that, and Mysore 1 to every 5. Burma was a close third behind Cochin and Travancore in female literacy (3.5 literate males to every literate female). In aggregate terms the increases were larger than in most regions, but undoubtedly there were other cases where literacy was being invested in (Table 3.4). So, how do we evaluate this historical legacy?

As Table 3.5 shows, Kerala's lead in literacy rates (over the Indian average) carried well over into the post-independence era.

Table 3.3 Kerala and India: death rates, 1931-2005 (per 1,000)

\begin{tabular}{lcc}
\hline Period & Kerala & India \\
\hline $1931-40$ & 29.1 & 31.2 \\
$1941-50$ & 22.3 & 27.4 \\
$1951-60$ & 16.9 & 22.8 \\
1970 (rural) & 9.2 & 17.3 \\
1995 & 6.0 & 9.0 \\
2005 & & \\
\hline
\end{tabular}

Source: UN 2000: 135. Figures for 1995 from Government of India 2001.

Table 3.4 All-India comparisons in literacy rates, 1931

\begin{tabular}{lc}
\hline Province or state & Literate per 1,000 aged 5 and over \\
\hline Burma & 368 \\
Cochin & 337 \\
Travancore & 289 \\
Baroda & 209 \\
Bengal & 111 \\
Mysore & 106 \\
Bombay states & 71 \\
Bihar and Orissa & 53 \\
Hyderabad & 50 \\
\hline
\end{tabular}

Source: Census of India 1931. 
Table 3.5 Growth of literacy in Kerala, 1901-2001

\begin{tabular}{lcc}
\hline \multirow{2}{*}{ Year } & \multicolumn{2}{c}{ \% literate } \\
\cline { 2 - 3 } & India & Kerala \\
\hline 1901 & 5 & 14 \\
1921 & 8 & 28 \\
1951 & 17 & 41 \\
1961 & 24 & 47 \\
1971 & 29 & 60 \\
1981 & 36 & 69 \\
$1991^{*}$ & 51 & 95 \\
2001 & 65 & 95 \\
\hline
\end{tabular}

Source: Tharakan 1990.

*1991 figures calculated from Dreze and Sen 1995.

But does Kerala's lead over other states in social indicators suggest a linear progression from that of its prior state policies under 'indirect rule'? There is a strong reason to answer this question in the affirmative, for had these earlier princely state policies not been implemented Kerala would have had a smaller lead over other states. This point has often assumed ideological overtones in subsequent debates about the efficacy of communist rule in creating Kerala's higher living standards. Indeed, the more difficult question is how to evaluate the effects of communist ascendancy and rule on Kerala's development, relative to those of its inherited policy legacy. One way to answer this question is through comparative logic, in addition to which there is the utility of counterfactual reasoning. Comparative logic would suggest that cases where policy initiatives had been undertaken by a nineteenth-century state in an attempt to modernize its polity, whether under direct or indirect British pressure, should also show some comparable distinctiveness in the post-colonial era. An obvious example would be the state listed below Travancore in Table 3.4, namely Baroda, which was also a princely state. Notably, the report of the Census of India 1931 noted that the Baroda state's educational efforts had 'made its rate of increase in literacy faster than other provinces.' (See Table 3.6.)

There is a real paucity of information on the Baroda princely state's education policies, which makes it difficult to conjecture why its literacy rates did not carry over to the post-independence era (hovering somewhere around 60-70 per cent compared with Kerala's 90-98 per cent). But it does suggest that the causal chain leading from one period of reform to another needs to be carefully specified. The strongest conclusion we can draw from the available evidence is that the policy legacy of welfare in Travancore and Cochin mattered, in so far as there were already-existing policies that could be democratized and used by the communists as mechanisms for garnering popular support. But was there a necessary historical determination, that is, had a communist party not developed, or had it 
Table 3.6 Progress of literacy in Baroda state, 1901-31

Locality

Number of literates per 1,000

\begin{tabular}{lrrrrrrrrr}
\hline & \multicolumn{4}{c}{ Male } & & \multicolumn{4}{c}{ Female } \\
\cline { 2 - 7 } \cline { 7 - 10 } & 1901 & 1911 & 1921 & 1931 & & 1901 & 1911 & 1921 & 1931 \\
Baroda state & 199 & 229 & 277 & 361 & & 9 & 25 & 51 & 80 \\
City of Baroda & 427 & 472 & 600 & 590 & & 27 & 84 & 218 & 214 \\
\hline
\end{tabular}

Source: Census of India 1931, Baroda, Vol. XIX, Part I, Report.

been weaker and its base more fragmented, would it have been able to push these policies in the direction of greater redistribution? The answer is that such a historical leap is unwarranted.

First, it has been noted that it was during the post-independence years, particularly 1956-57 and 1979-80, that increases in capabilities and entitlements through the communists' policies led to demographic breakthroughs (Caldwell 1986). The growth of state capacity in administering medical care in Travancore and Cochin contrasted sharply with the failure of the British to implement similar health facilities in Malabar. The death rate in Malabar was about 23 per 1,000, roughly double that in Travancore and Cochin even as late as the mid-1950s. In 1943, in the midst of a cholera epidemic, nearly 40,000 people died of cholera, dysentery and diarrhoea (Jeffrey 1992: 191). During those years the communists formed 'Red Guard' anti-cholera teams, going from house to house to give advice on cleanliness and prevention of disease. After they won elections in 1957, communists enacted universal immunization for children, and opened hospitals in the northern region of Malabar, along with introducing a wide spread of literacy programmes to the poor, land reforms and minimum wage legislations. Although the effects of some policies such as land reforms, housing or minimum wages upon social indicators of well-being are probably more indirect than health or education policies, it is reasonable to assume that these policies would have had feedback effects on various dimensions of poverty and deprivation. Second, this 'redistributive emphasis' stands in sharp contrast to the more elitist policy of the princely states, whose reforms were largely intended for the upper castes, and were still largely unattainable for the lower castes (Jeffrey 1992: 189). In a poor area of Ernakulam town in Cochin, a report noted the 'stagnant pools of dirty water ... breeding plenty of mosquitos,' and the 'horrible stinking smell resulting from the absence of latrines' (ibid.: 190). Elephantiasis, hookworm and cholera plagued the poorer sections of the populations, as did malaria and typhoid (with 280,000 cases of malaria a year reported before the Second World War, a figure which allows for considerable under-reporting).

Pursuing the question of the causal chain that linked the two eras of reform, then, requires the use of historical analysis, not merely a quantitative logic of explanation. Most importantly, if lower caste and class protest had their origins in 
the early period of welfare reforms that were designed to prevent such movements, the task of historical explanation is clearly to understand this counter-intuitive outcome. In this regard I will argue that there were two causal chains at work: first, the role of missionaries in stimulating state reforms of caste disabilities, and thus providing the beginnings of lower caste protest movements, and second, the growth in the state, its 'infrastructural' penetration of society, which stimulated a 'tradition' of popular demands for welfare reforms from the state. This was a tradition that was available for utilization, but it was not predetermined in the order of things that it would be perpetuated. That both these causal streams merged during the mid-twentieth century, culminating in the communists' utilization of Kerala's prior policy legacies to create a new social policy regime, requires explanation. It provides us with the crucial link between the nineteenth- and twentieth-century welfare reforms, as these movements became the 'conveyor belts' for Kerala's 'legacy' of welfare, but in largely unintended ways.

\section{Lower caste protests and the state in Kerala}

State formation in Europe provoked two kinds of popular rebellions - those that were primarily 'defensive' or reactive (rebellions or jacqueries), that is, concerned largely with resisting taxes, and those that were 'offensive' or proactive (for example demonstrations, strikes or petitions) and concerned not with resisting the encroachment of the state, but in getting a larger share of power or recognition (see Tilly et al. 1975). In British India, both kinds of rebellion and protest movements occurred, but notably in Travancore movements among lower castes (explicitly organized as movements to reform the caste system) took largely proactive forms, encouraged by the new possibilities for reform that arose in the colonial era. In other words, they increasingly showed attempts to use the encroachment of the state to their advantage rather than resisting it, and aimed at creating larger associational assemblies and making claims to rights 'as a consequence of general principles' (Tilly et al. 1975: 52-53). These protests were not all directed at the British state - 'communal' riots and inter-caste competition were inherent features of lower caste protests in Kerala, and were situated in the strange and complicated nexus of the princely-colonial state, protesting the Travancore and Cochin upper caste Hindu monarchies while turning to the British administration (along with the missionaries) for reforms.

The first crucial feature to note is that movements among the low caste Ezhavas and Pulayas first developed in Travancore and Cochin, rather than in Malabar. Notably, in these two regions, in direct proportion to the decline of caste as a factor in property ownership, the relevance of caste grew exponentially in the 'public sphere'. In Malabar, where the British ruled directly, they generally abstained from involvement in social reform. However, in Travancore and Cochin, the intransigence of the conservative Hindu princely states and the growing acts of protest among low caste Shanars, Pulayas and Ezhavas became 
additional reasons for the threat of interference by the British Resident. These were, of course, secondary to the primary interest the British had in opening up the region to plantation capital. Growing acts of protest by lower castes threatened political stability, and appear to have been the main reason for British intervention.

The collective association and aggressive protests by lower castes in Travancore and Cochin would not have been possible without the independent role played by the Christian missionaries. It is not that the missionaries directly led these protests, but they provided crucial resources - ideological, material, and increasingly, political - for the lower castes to challenge the Travancore state (Kooiman 1989). Despite the hostility of the Dewan in 1808-09, when missionary activity first began, a failed attempt to oust the British by the same Dewan led to a series of treaties between the British and the Travancore state. Missionary activity now became identified with British power, and was accepted with some gratitude by the monarchy of Travancore (ibid.: 54).

The missionaries were interested in mass conversions among Hindus, and found, as mentioned earlier, that it was only the lower castes who were drawn to their activities. ${ }^{2}$ Lower caste interest, moreover, appeared to be stimulated by the fact that their material 'grievances are more speedily, effectually and cheaply redressed by making the missionary their friend than in any other way' (quoted in Jeffrey 1978: 39). In particular, conversions rose during famines (e.g. 1810-12), as missions planted trees and dug canals and tanks to provide some relief. Land grants to missionaries from the princely state also helped to attract new converts, as did the drop in poll tax ordered by the Dewan for Christians (Kooiman 1989: 72$)^{3}$

The instrumental approach that lower caste members held towards the Christian missionaries is evident from the fact that conversions to Christianity were quite often temporary. Fresh converts were drawn by the promise of missionary redressal of their grievances, in particular through the missionaries' ability to lobby the British colonial government; however, when their hopes failed to materialize converts often reverted to their old religion (Kooiman 1989). Sometimes they went in and out of the missions, drawn by the reduction in corvée labour for Christians during those months when the state's exactions on labour were the highest, for example during Hindu festivals. Increasingly, the ability of missionaries to challenge Nair demands on the lower caste converts won the sympathy of many among the lower castes, who came to see them as their new representatives in the fight against caste discrimination. ${ }^{4}$

The politics of missionary involvement among Kerala's low caste poor cannot be subtracted from the overall colonial mission which the missionaries believed in. The push to reform casteist practices was a reflection of their belief that these were 'unchristian,' and defied the mission of civilization. Inducing the 'savage' lower castes to give up practices such as demon worship, for example, wholly articulated with their own mission of spreading Christianity, while at the same time it introduced another avenue towards sanskritization (see p. 34). Ezhavas in 
particular shied away from converting to Christianity, but there were strong similarities between their reformer, Sri Narayana Guru's message and that of the missions (Kooiman 1989). Thus, for example, a crucial dimension of the missions' efforts was to instil a new work discipline among its recent converts, in particular through prohibitions on drink. Interestingly, the SNDP, the Ezhavas' reform organization, preached the identical message of discipline and abstinence. Not surprisingly, these injunctions pleased plantation capital and managers, who felt more inclined to hire Christian labour, who they found to be better workers. The conjoining of capitalism and Christianity, then, was the direct result of mission activities. In another sense, too, missionaries of the LMS and the Church Missionary society (CMS) campaigned against disabilities that sat at odds with the demands of a new capitalist economy, by launching campaigns to abolish slavery and forced labour. The missionaries lobbied the British administration in Madras and gradually, in the face of riots (such as the riots among Pulayas agitating for the right of women to cover their breasts, also known as the "breastcloth disturbances'), succeeded in creating a sufficient fear of civil disturbance in Travancore. The Madras state began to threaten annexation of the territory controlled by the Travancore monarchy, in order to force it to modernize its civil and political institutions.

The mechanism for social reform in mid-nineteenth-century Travancore appears, thus, to have originated with a combination of missionary influence and lower caste self-induced activity, whose highly agitational methods put pressure on the British to intervene, who in turn forced reform upon the Travancore state because they feared escalating insurgency. In this respect, Kerala appears to be a distinct anomaly, for although missionaries were active in other parts of British India there appears to be no comparable mix of factors elsewhere. The key factor here was the power of the missionaries to influence British policy regarding caste; indeed, by threatening a rise in protest and instability the missionaries were able to force the British to pursue a more interventionist policy with the princely rulers. In contrast, in their own directly administered district of Malabar, the British were much less interventionist, perhaps because missionary activity was centred in Travancore and Cochin.

Undoubtedly, the disciplinary effects of missionary activity, and the corresponding self-disciplining of the hitherto 'heathen' castes was the beginning of their induction into the incipient bourgeois state. This incorporation was enabled by the state itself. A new kind of caste-based self-discipline within a capitalist economy was developing during this period, and was further extended through the twentieth century. As populations became resources for factories, these forms of discipline became both cause and effect.

\section{From insurgency to political organization}

The rise of social reform movements towards the later nineteenth century, and their associated modern caste associations among the Ezhavas, Pulayas and 
indeed among the upper caste Nairs, differed from the earlier mid-nineteenthcentury protests. These associations were largely a response to the new opportunities afforded to the lower castes in the era of rapid modernization and commercialization. They also represented the aspirations of a growing middle class within the low castes, particularly among the Ezhavas, whose caste reform association was the largest and most successful. The phenomenon of the rise of caste associations, it must be noted, was not unique to Kerala. From the midnineteenth century onwards, lower castes across British India increasingly organized themselves into caste associations (or sabhas). The spread of communications and markets began to link geographically separate communities and local sub-castes, thus enabling the formation of such associations (Rudolph and Rudolph 1966). In Travancore and Cochin, the extensive land reforms led by the princely states, and the spread of health care and education were accompanied on the other hand by growing population pressure (a direct consequence of the fall in death rates) and the absence of corresponding industrial growth. In 1901, 47.4 per cent of the total population was dependent on agriculture; in 1911 this proportion rose to 53.6 per cent, and to 54.3 per cent in 1931 (Census of Travancore 1931, Part I, Report). The Census estimated that a subsistence holding for a family of five would be 10 acres; however, only 4.5 per cent of the holdings were 10 acres or above. Most holdings, roughly 87 per cent, were below 1 acre in size (ibid.). For castes at the bottom of the hierarchy, opportunities in the rapidly expanding plantation sector, government administration and in private trade were avenues for upward mobility. For example, a survey taken in Cochin as early as 1891 showed that the cost of living had risen by 103 per cent between 1850 and 1890. Wages for non-agricultural labourers in the plantations, coir industry or public works department had risen by 167 per cent and for artisans by 140 per cent. With the cost of living for a man at Rs 42 a year and for a woman at Rs 29.5 a year, a Rs 6- or 7-a-month job in a government service was especially lucrative for those among the lower castes who could acquire the necessary education (Jeffrey 1976: 105).

The entry of British capital in the form of plantations and coir factories, and the land reforms, disrupted the caste-class correspondence prevalent in Travancore and (to a lesser extent) Cochin. By the 1870 s a small Ezhava middle class was forming in Travancore as some of the profits from the coir trade filtered down. Some of them were able to acquire land, some opened coir factories and some made a small fortune in the toddy ${ }^{5}$ and arrack trade which more than doubled between 1860 and 1880 (ibid.: 141). The implementation of laws permitting the partition of joint families' land resulted in the selling of land by the matrilineal, joint-family Nairs. Most of this land passed into the hands of the Ezhavas and Syrian Christians (Varghese 1970: 103). The almost absurd degree of social subjugation and marginalization experienced by the Ezhavas did not fit well with their newly acquired economic status.

The first members of the Ezhava caste movement were drawn from the newly prosperous Ezhavas. They began to join the Sri Narayana Dharma Paripalan 
(SNDP), which was founded by Sri Narayana Guru, a religious reformer, in 1895. Narayana Guru's emphasis was on establishing idol worship among Ezhavas, and was rather unique in this respect among religious reformers in India. But since Ezhavas were not allowed idol worship they engaged in the 'polluting' practices of totem worship, the cult of demonology and animal sacrifice. Thus Narayana Guru's first attempt was to lift Ezhavas out of such polluting practices by erecting Brahminical idols in new places of worship (Chandramohan 1987). Through Narayana Guru's writings and lectures the SNDP advocated the idea that caste was irrational and unscientific, which made it a crucial foundation for the rise of social movements based upon the rejection of religion-induced oppression and hierarchical social customs.

Among the SNDP's demands were the right for Ezhavas to use public roads, admission for Ezhava children into schools and representation in the services (Menon 1966: 459). Their primary tactic was the use of memorials or petitions to the government. Members were asked to give up superstition, wasteful social customs and practices and follow an austere path. A similar movement arose among the low caste Tiyyas of Malabar, who were also traditionally toddytappers and distributors. A small Tiyya middle class grew among those who took advantage of missionary schools and worked their way up to administrative positions as lawyers, sub-judges and deputy collectors (Menon 1994). Some Tiyyas set up cloth mills in the 1920s as the boom in cash crop prices yielded profits. The Tiyya movement was strongly influenced by the SNDP movement in Travancore, in particular in its appeal for caste equality and economic selfreliance. Its organization, the Gnanodaya Yogam, encouraged Tiyyas to make pilgrimages to Brahmin temples, which would help them to learn and adopt Brahminical rituals. The Tiyya newspaper, Mithavadi, published articles on the eating habits of Brahmins and printed suggestions about Brahminical practices that Tiyyas could learn from (ibid.).

To causally link the eventual insurgency of radical workers' movements in either the early or later caste reform movements requires some caution. The use of the colonial state as a mediating agency by the early lower caste movements in Travancore and other parts of India suggests that they were not firmly anticolonial. Indeed, they were often 'loyalists,' arguing that the British had a greater sense of justice than the princely states (Ravindran 1972: XCVI-II). In contrast, the movements that developed during the 1930s and 1940s were firmly anticolonial, raising for the first time the connections between colonial capital, British rule and class-based exploitation. We see no hints of this critique among the early caste movements. The later Ezhava and Tiyya movements emphasized self-help and economic self-reliance, which in principle stood directly contrary to the principle of class-based organization and mobilization against a definite class antagonist. They shared 'sanskritizing' tendencies, ${ }^{6}$ that is, the attempt to borrow and emulate from 'Brahminical practices' and seek upward mobility within the caste hierarchy. Examples of such emulation include eschewing liquor, renouncing widow-remarriage, taking to vegetarianism, and adopting worship of 
Brahminical deities and other religious rituals. The leaders of both movements urged their followers to eschew toddy-tapping because of its 'demeaned' status as a 'low' caste practice, to take on austere life-styles and refrain from wasteful practices. 'Liquor is poison,' Narayana Guru preached, '[i]t should not be manufactured, served or drunk. The toddy-tapper's body will stink, his cloth will stink, his houses will stink and whatever he touches will stink' (Chandramohan 1987: 65).

Although Narayana Guru advocated a strong anti-caste position, it is unclear if the SNDP's practices were consistently embedded in this principle. Equality was defined as equality with other castes, which was embodied in the slogan 'one caste, one god, one religion.' Members of the Ezhava and Tiyya caste associations sought to erect their own temples; but these were devoted to gods regarded as belonging to the Brahminical pantheon (Menon 1994). They both employed tactics of memorials and petitions to the state, and brought the caste issue to debates in their respective legislative assemblies.

This evidence leads us to a crucial observation that the deep structural transformation of Kerala's social hierarchies through land reforms as well as other state-led reforms 'from above,' resulted in the paradoxical empowerment of and rise in protest among middling sections of the untouchables who had been able to acquire enough land and resources to make increased citizenship claims. These were primarily the Ezhavas, whose literacy levels as a result of state initiatives had shot up roughly 115 per cent between 1894-95 and 1903-04, the highest increase of any caste within Kerala. Yet, the movements among the Ezhavas and their counterpart Tiyyas in the north, did not simply spell the beginning of radical protest or communist ascendancy, for their aims were typically 'sanskritizing' and moderate, aimed not at the destruction of the caste system, but at citizenship claims within an incipient bourgeois state. While constituting a new regime, the communists pushed the welfare policies to new heights based on an entirely different logic from the indirectly ruled princely state, but as we will see in the following chapters, while the redistributive thrust of their policies was a direct outcome of radical mobilization, the communists 'elected' to operate within a bourgeois state, dependent on capitalist investment in a competitive national market. Unlike the nineteenth-century reforms which were led by princely states seeking to expand market forces, the communists created unbridled welfare reforms in opposition to logic of the market. Radical mobilization stumbled upon the ambivalent relationship between state and market. This will be taken up in Chapter 6. Before that we turn to the specificities of left mobilization in Kerala, showing that left hegemony in the region was won through specific practices within the nationalist movement. 


\section{Political practices and left ascendancy in Kerala, 1920-47}

This chapter examines the contextual growth of left practices in Kerala, seeking to understand how the prevalence of lower caste protest, as discussed in the previous chapter, played a role in generating these practices, and how, through this link, the leftists created a proto-bourgeois revolution. The link between caste and class movements has been assumed as obvious in the case of Kerala. Jeffrey (1978: 82), for example, states that 'because caste roughly coincided with class in Kerala, agitation against caste disabilities was to lead the poor towards class consciousness' (my emphasis). The evidence, however, suggests that rather than caste-class coincidence, it was the gradual class differentiation within castes that was key to the lower caste movements that emerged in Kerala. Moreover, the probability that lower caste movements would 'translate' into class-based movements in the pre-1947 era, that is, raise class-specific demands regardless of caste differences among classes, depended on the regional specificity of the nationalist movement. We must bear in mind that class formation of the kind that occurred in Kerala was unique, and with a few exceptions this remained the case in post-independence India.

\section{Nationalism and the emergence of an 'anti-Congress' movement in late colonial Kerala, 1920-34}

A crucial variable in the process of determination of class-based radicalism in the immediate pre-1947 period in British India was the organizational strength of the Congress Party. In all three regions of Kerala, the Congress Party was much weaker than elsewhere in India until the advent of the CSP (roughly until 1935). This weakness can be seen in part as a reflection of the social structure of the three regions, although I will argue subsequently that the political strategy and tactics of the Congress Party must be granted considerable autonomy in understanding this weakness. In Malabar, the weakness of the Congress Party was a product of the highly polarized caste hierarchy in which the social distance between the upper and lower castes was so marked as to render the possibility of unifying their interests under the broader ideology of nationalism somewhat thin. The upper caste landlords (jenmis) were mostly loyalists with little interest in 
joining the Congress Party. Although for a short while during the 1920s the Congress Party became the vehicle for the middle tenants (kanomdars) to wage a struggle against the landlords for tenancy reforms, their interest in Congress did not last after they won the Malabar Tenancy Act of 1930. The form of rule in the princely states mattered for this process as well, since until 1938 it was Congress policy not to interfere in the internal affairs of the princely states. In large part this was the result of an attitude that had carried over from the pre-Gandhian or pre1920 s period. Princes and Dewans were often elevated to the status of nationalist heroes who had proved that Indians were equally capable of ruling their own society. In addition, princes were viewed as victims of the British lust for power (Manor 1977: 83). It was only later during the 1930s that Congress leaders began to express criticism towards the princely states, and officially the policy of noninterference was only withdrawn in 1938. This meant that even when Congress leaders were active in social reform campaigns and anti-state movements in the princely states there was no established organization of the Congress Party that could lead these disparate campaigns.

Comparatively speaking, within Kerala the nationalist movement was stronger in Malabar than in Travancore or Cochin, whereas the lower caste movements were stronger in the two princely states, rather than in Malabar (Gopalan 1959). It is somewhat difficult to establish whether the association between the absence of a formal Congress organization and the strength of low caste movements in the two princely states is a mutually causal one because of the absence of cases where both conditions hold. Whether the Congress Party would have diluted the radical content of lower caste movements or been forced to contend with it depends upon its leadership and social base. It is certainly worth asking what might have happened had the Congress Party been a stronger organization, which attempted to co-opt or suppress the anti-caste radicalism of the lower caste movements, particularly as these tendencies emerged during the 1930s. ${ }^{1}$

What was the relationship between the Congress Party and lower caste protest organizations in Kerala? By the early twentieth century, the Ezhava's caste organization, the SNDP, was coming to realize that its methods of petitioning were not yielding much success. Even though more Ezhavas were literate than in the mid-nineteenth century, they continued to be denied access to government services and jobs in the largely Brahmin-dominated princely states. They were still excluded from entry into most temples, public roads and some public buildings. In 1915 a young journalist named T.K. Madhavan took leadership of the SNDP. He was deeply influenced by Gandhi, and felt that the success of the Ezhava movement depended on its links with the wider nationalist movement in India. Madhavan drew the SNDP into closer links with Congress activities such as Prohibition, the struggle for civic liberties, and the eradication of untouchability. In 1924 Madhavan led the famous Vaikom Satyagraha, demanding the right for low caste Hindus to use the roads surrounding the Vaikom Temple in Travancore (but Madhavan did not go so far as to push for temple entry). The campaign dragged on for a year or more, and ended with the 
compromise allowing low caste Hindus to use some of the roads around the temple (Jeffrey 1976: 259).

The symbolic value of Gandhi's support for the Vaikom Satyagraha campaign was considerable, because it put the stamp of the nationalist movement on what was heretofore a localized movement in a remote part of India. ${ }^{2}$ Yet it is more important to note the fact that the Ezhava leader Sri Narayana Guru, despite his 'moderate' methods in comparison to later radicals within the movement, defied Gandhi's attempts to impose non-violent tactics on the Ezhavas (in this context 'non-violent' stood for civil disobedience and non-defiance of the authorities). ${ }^{3}$

The early defiance of Gandhian methods, in addition to the weakness of the Congress Party in Travancore, allowed, as Jeffrey (1978) puts it, 'new, rival doctrines ... [to contend] ... ceaselessly, everywhere'. It was extremely significant because this defiance was to be repeated in the later pronouncements and tactics of the CSP.

In 1933 a split in the Ezhava movement became apparent, with younger, more radical members seeking to replace the old slogan 'one caste, one religion, one God' with 'no caste, no religion, no God'. At a meeting in May 1933, for example, they declared that Ezhavas were not Hindus. Such pronouncements continued through the years, often exhorting Ezhavas to convert to Christianity or Sikhism. ${ }^{4}$ There now appeared a split between those choosing more 'moderate' methods and goals such as entry to government jobs, temple entry, etc. and those beginning to make the link between caste reform and class, particularly in the context of the post-Depression period. ${ }^{5}$ Far from showing signs of decline, however, the SNDP continued to grow through the 1930s; in 1928 its membership was 50,684 with 255 branches, and by 1938 it could claim a membership of 200,000, with 526 branches (Menon 1966: 463).

In granting the 'political' relative autonomy, it is my argument that the absence of a formal Congress Party organization and movement in Travancore and Cochin allowed caste movements to grow autonomously and avoid absorption into the nationalist movement. ${ }^{6}$

The origins of the Kerala branch of the Communist Party of India (CPI) are unique even within India, because it began as a faction within the dominant and mainstream anti-colonial Congress Party (known as the Indian National Congress). Established in 1934, the Congress Socialist Party (CSP) as this left socialist faction called itself, gained rapid political ascendancy and established a mass base among tenants, workers and some sections of the middle classes in Kerala. In 1940 the CSP split from the Congress Party and merged with the CPI. In most other cases across India where the communist party is relatively influential, most significantly West Bengal, but also Andhra Pradesh and Tripura, it developed independently from the outset, that is, outside of, and in direct antagonism to, the Congress Party and mainstream nationalist movement (until the CPI adopted a policy of working within the Congress Party in 1936-37). 


\section{Congress Party hegemony and 'political opportunities' for left parties}

The Indian National Congress, commonly referred to as the Congress Party, was formed in 1885. Its origins were largely urban, a meeting of dissatisfied professionals and intellectuals who sought greater autonomy within the system of colonial rule. It was only during the 1920s that the Congress Party began to assume the contours of a more popular movement, and with Gandhi's ascendancy within the party it began to strike roots in rural areas and develop into a fullfledged political organization. Any analysis of the fortunes of the left, and the growth of class politics must take into account the specific modes of Congress expansion and consolidation of its hegemony. Undoubtedly the largest hegemonic leader of the nationalist movement, its strategy and tactics of anti-colonial protest determined the terrain upon which other parties were forced to act.

The leadership of anti-colonial nationalist movements across Africa and Asia have generally marginalized questions of hierarchy and redistribution within the movement, except in the revolutionary situations of Vietnam and China. While on the one hand such movements were (necessarily) based upon radical, universalistic premises, often denouncing monarchical rule, landlordism and challenging the local edifices of colonial rule, nevertheless, in attempting to forge broad coalitions against colonial rulers, nationalist leaders (often themselves drawn from the upper echelons) attempted to water down radical agendas that would seriously undercut the basis of class and other hierarchies. This outcome often emerged after a period of upheaval and flux, during which workers' movements or other subordinate groups were able to penetrate and utilize the nationalist movements to raise important questions about inequalities and power, but without succeeding in capturing the nationalist movements.

To understand why Kerala's pattern of left ascendancy defied this more general pattern, particularly in the absence of a revolutionary strategy or what Gramsci would call a 'war of manoeuvre', one has to examine how they employed anti-colonial nationalism to tap the potential for class formation, both in terms of the ideology of nationalism and its practice in the form of the Congress Party. Nationalism can be thought of as an extremely powerful and seductive political (as well as cultural) resource, which can appeal to any project of collective formation. As Lekas (1996: 271) suggests, the 'historically unprecedented plasticity of forms, dynamism, expansiveness and durability of nationalism' has given it a 'supra-class' dimension, allowing political leaders who utilize nationalist rhetoric to draw support from multiple classes. In particular, the importance of egalitarianism in nationalist ideology, the demand for civil rights and its antagonism to traditional forms of patronage and loyalty, can be particularly appealing to the subordinate classes. On the other hand, the plasticity and amorphousness of nationalism can equally render it in a contradictory relationship to popular mobilization. There is little doubt that the Indian pattern of inclusion and exclusion of workers (and poor peasants, tenants and sharecroppers) from the nationalist movement is suggestive of patterns elsewhere 
(see Beinin and Lockman 1987; Kumar 1984; Chandavarkar 1998; Sarkar 1983; Damodaran 1992; Henningham 1982; Chatterjee 1993).

\section{Colonial state formation and Indian anti-colonialism}

The reforms of 1935 gave the Congress Party a share in local and provincial administration for the first time, and initiated their transition from movement to electoral party. ${ }^{7}$ Indeed, the character of the Congress Party as a movement and party was determined by the granting of incremental reforms by the British, which all but foreclosed the possibilities for a revolutionary party to assume leadership of the anti-colonial movement. Compared with Tsarist Russia for example, or Dutch Indonesia, the British had allowed freedom of the press and a modicum of civil liberties in India. The Indian working class possessed rights denied to many workers elsewhere - the right to form trade unions, for example, through the Indian Trade Union Registered Act of 1926 (Joshi 1992: 14-15). Under these conditions, various forms of protest could be combined in effective ways - strikes, public demonstrations and meetings were legal activities most of the time. The claim presented here is not that the British were particularly tolerant of leftist or radical dissent, indeed they resorted freely to means of silencing dissent that ranged from imprisonment to the penalty of death. But compared with the Dutch, Portuguese or French colonialisms, the British relied upon a semblance of liberalism, and over time attempted to entrench their rule by resorting to gradual reforms, paying attention to social and educational reforms which won them a degree of legitimacy (in the sense of a state's legitimacy) from sectors of Indian society that included caste organizations attempting upward mobility. Guha (1997: 65) has characterized the British colonial state in India as an instance of 'dominance without hegemony', as an 'absolute externality' much like a despotism 'with no mediating depths, no space provided for transactions between the will of the rulers and that of the ruled'. This characterization is not entirely accurate, as I have argued. In some respects the British colonial state mimicked the bourgeois state by allowing piecemeal liberties, while in other aspects its actual character was more autocratic.

Left parties entered a complicated field, then, with the Congress Party occupying such a central place in the nationalist movement. As Ho Chi Minh commented to a CPI delegate from Kerala when asked about his success: 'There you have Mahatma Gandhi, here I am the Mahatma' (quoted from interview with K. Damodaran, New Left Review, 1977). One may argue that such a 'field' delimited the set of choices available to revolutionary parties on the left, for if they were to have any kind of stake in the political sphere they were forced to contend with the hegemony of the Congress Party over the nationalist movement. ${ }^{8}$

This hegemony was not without breaks. Although the Congress Party could claim to be a mass movement of sorts, it is widely acknowledged among Indian historians that its claims to hegemony were fragile at many points, and had to 
contend with numerous challenges from peasants, workers, left parties, and religious parties such as the Muslim League (Chatterjee 1993; Guha 1997). In the post-Depression years, particularly from 1934 onwards, worker militancy grew, with strikes doubling the man-days lost per year (Revri 1971). In very few instances were these strikes led by the Congress Party, most often being led by the communists instead. Particularly important to note, especially for the purposes of the analysis here, is that after the Karachi Resolution of 1931, the Congress Party under Jawaharlal Nehru's socialist swing became rapidly radicalized, and formed an umbrella organization for a variety of leftist groups and forces. This left turn within the Congress Party spurred the Congressites in Kerala, as elsewhere, to include the subordinate agrarian and industrial classes within the fold of the nationalist movement and to raise questions of internal hierarchies and redistribution, tenancy reforms, anti-landlord measures and workers' rights. This fluidity within the Congress Party itself made possible other political formations that did not necessarily have to choose between the mainstream nationalist movement and radical insurgency. In view of this it might then be more appropriate to characterize the Indian nationalist movement as a field of opportunity and restraint for the political struggle of classes during its 'popular' phase from 1920 to 1947.

The concept of 'political opportunity structures', which refers to the 'array of possibilities' available to insurgent groups and social movements when there are breaks in state repression, international events and shifts in 'elite' ties to the state (McAdam 1982) is useful for understanding the situation confronted by left parties in British India. The ebbs and flows of nationalist campaigns themselves, such as the non-cooperation movement, civil disobedience movements, and the smaller campaigns that constituted the nationalist movement presented important openings for left practices. International events such as the two world wars and the Great Depression (larger events), and a range of smaller events, as well as breaks in the success of the Congress-led campaigns (in no small part a direct result of the interplay between Congress campaigns and colonial state repression/accommodation) provided opportunities for left parties to raise doubts about Congress strategy. These doubts were given substance in the wake of the Great Depression of 1929-30, which devastated vast stretches of the countryside and jeopardized the livelihoods of millions. Many felt that the Congress Party had conceded too much to the British, and had failed to be consistently militant, while at the same time this was an important conjuncture worldwide for the rise of peasant radicalism. In the ensuing phases of internal unrest within the Congress Party, most notably during the early 1930s, the two primary left party formations - the Congress Socialist Party and the Communist Party of India - became increasingly visible and active.

The potential for left ascendancy and hegemony depended in part upon the degree of hegemony and organizational strength possessed by the 'right wing' of the Congress Party in particular regions. The mechanisms by which the expansion of Congress organization suppressed popular radicalism on a larger level have not 
been very well understood, and arguments often assume a certain degree of circularity. ${ }^{9}$ One factor was the strength and reach of Congress Party organization. ${ }^{10}$ This is not a tautological assertion. Since the Congress Party was the strongest and most resourceful party, its presence was likely to significantly affect what other parties could do.

The strategy of mass mobilization adopted by the Congress Party leadership was to strike a fine line between restraint and radicalism. This followed from the 'compromise-struggle-compromise' strategy adopted against the British state (Chandra 1986) whereby Congress leaders alternated phases of negotiation and securing gradual concessions from the colonial state with phases of mass civil disobedience. However, the latter phases of struggle were carefully orchestrated, their forms carefully chosen and, under Gandhi's specific instructions, class antagonisms which were dangerously hovering beneath the surface were not allowed to erupt. The Congress under Gandhi, and to a lesser extent under Nehru, 'represented' the 'dumb millions' with tremendous self-consciousness about their 'responsibility' to not let popular agitation get out of control. As Pandey (1988: 126) argues, there was a distinctly paternal element to their leadership vision, one that existed independently of the more strategic concerns to utilize the political opportunities of British rule. It is not enough to argue that Gandhi's strategy was aimed at benefiting a particular class such as the bourgeoisie or landlords because participation at the height of campaigns such as the civil disobedience movement of 1930, of which Gandhi was the primary architect, extended across the bourgeoisie to include peasants and tribals (Sarkar 1976). ${ }^{11}$ Mass campaigns led by the Congress party such as the salt satyagraha, non-cooperation and civil disobedience movements, if not their town-based and urban tactics of picketing or boycotts, drew a large following that cut across 'class' and other social divisions, and possessed great emotive and mobilizational value.

On the other hand, there is no doubt that boycotts of British manufactures, norent campaigns against the colonial state, picketing of liquor shops and spinning, primarily targeted the British state rather than entrenched class interests. One may argue that Gandhi's romantic vision of the self-sufficient village, and his belief in the benevolence of the 'good' landlord shared an 'elective affinity' with existing caste-class hierarchies. Thus although Gandhi reinterpreted the caste system on the basis of the popular and devotional Hindu religious protest movement (bhakti) and argued that salvation was available to all regardless of caste rank (Frankel 1978), he simultaneously defended the existence of the caste system. 'I do not believe the caste system ... to be an "odious and vicious dogma," 'Gandhi argued:

It has its limitations and defects, but there is nothing sinful about it, as there is about untouchability, and if it (untouchability) is the by-product of the caste system, it is only in the same sense that an ugly growth is of a body, or weeds of a crop. It is as wrong to destroy caste because of the outcaste, as it would be to destroy a body because of an ugly growth in it.

$(\text { Tendulkar 1951: 193) })^{12}$ 
Although Gandhi balked from encouraging class confrontations, the Congress Party was faced with the need for popular support while at the same time suppressing popular radicalism. The very success of the Congress Party's anticolonial strategy depended on its ability to extend the party's legitimacy, that is, to claim to be the sole representative of the 'people'. To claim this 'hegemony', the Congress Party needed to suppress or compromise radical challenges to its programme at the local and regional levels. As Gandhi put it:

Indeed there should be no competition between the Congress and the other organizations. If we would be true to ourselves, the Congress would be admitted by all to be the only nationalist organization to which the members of the other organizations, whilst retaining their own, would deem it a pride to belong. For this consummation Congressmen should show striking results in constructive effort and broadest toleration towards those holding opposite views, so long as they do not come into conflict with the avowed object of the national organization.

(Gandhi, Collective Works 41: 539, quoted in Guha 1997: 130)

Gandhi's strategy was to strike internal compromises with such groups, revolutionaries in Bengal for example, whose ideas about fighting the British challenged the basic modalities of the Congress leadership. A philosophy of nonviolence, argued a Bengali revolutionary, was a philosophy 'arising out of despair' (Sanyal to Gandhi, Young India, 12 February 1925). Yet Gandhi persuaded them to abstain from violence against the British for one year in return for their being allowed to join the Congress Party. Gandhi's rise to prominence within the Congress Party in 1920 was based in part upon his ability to absorb dissident opinion within the Congress Party, and yet to steer it in a particular direction. Popular, that is, caste-based and class-based, radicalism among workers and the lower peasantry was profoundly affected by this particular form of Congress hegemony. Although this point cannot be discussed in enough detail here, it is important to avoid assuming any simple links between Gandhi's political philosophy, his pragmatic strategy, and Congress tactics and practices on the ground, because the former were filtered through highly specific local social and political structures.

\section{Weak dominant class opposition}

The political behaviour of dominant classes and class alliances are key factors in explaining variations in processes of democratization (Moore 1966; Rueschemeyer et al. 1992). In particular, a weak political response to capitalist transformation and their weakening class position, by the landed aristocracy and dominant classes, is offered as a crucial factor in explaining left party ascendancy. The success of Swedish social democratic ascendancy, for example, has been 
attributed to the weak response to these factors on the part of both classes (Castles 1978).

How well does this hypothesis hold in the case of Kerala? The British alliance with Malabar's jenmis or landlords had not only reinforced a highly inegalitarian class structure, but also exacerbated the effects of the caste hierarchy by giving landlords the freedom to enforce their caste privileges without fear of sanction. As a result two crucial dynamics came into play by the 1920s: first, intra-caste struggles that split the two upper castes - the Nairs and Namboodiri - along generational lines; and second, the inter-caste struggle between Nairs and Namboodiri. Both struggles affected the class and caste composition of the Congress Party during the 1920s and particularly during the early 1930s because as the caste hierarchy came to be questioned by all castes simultaneously during this period, and came under sustained attack by the upper caste organizations, the Congress Party was forced to become a part of, instead of resistant to, these ongoing social struggles.

Prior to the transformation of the caste system in the 1920s and 1930s, the Namboodiri caste was steeped in tradition and superstition to the extent that its members were not allowed to learn English or occupy public office. Namboodiri women were practically secluded (in purdah or the veil) from the outside world. The imposition of British colonial rule had deprived Namboodiris of political power, and in the realm of the professions they were entirely eclipsed by the Nairs who had strongly pursued western education. In 1910-11 a few Namboodiris founded the Yogakshema Mahasabha to protest the anachronistic customs that continued to circumvent their ascendancy vis-à-vis other castes. They demanded English education, and an end to the purdah system for women. In the early 1920s young, radical Namboodiris formed the Nambudiri Yuvajana Sangham (Youth League). Its members published a monthly paper called Unni Nambudiri to argue for the ideals of social revolution not unlike the radical Ezhavas in Travancore (Menon 1966). Younger Nairs simultaneously formed the Nair Service Society that pressed for more education, and particularly struggled against the joint-family system. For them the nationalist movement, and thus the Congress Party, was a means of spreading the anti-caste movement and many of the younger members joined the Congress Party in Malabar in large numbers (Gopalan 1959; Menon 1966; Namboodiripad 1968).

During the 1920s the Congress Party was also the site of an inter-caste and inter-class struggle, between the largely Namboodiri landlords and the Nair upper tenants. The Nairs waged a successful struggle through the Congress Party to win the Malabar Tenancy Act of 1930 that granted them full occupancy rights to kanom lands. The split within the dominant property controlling class along caste lines appears to be quite specific to northern Kerala. ${ }^{13}$

Despite the ongoing struggles between landlords and the upper tenantry, and early civil disobedience campaigns, the Congress Party in Malabar was far from being a mass party during the 1920s. Because of their part-time involvement in Congress activities, its leaders were popularly referred to as 'Sunday 
Congressmen'. In 1922 Congress Party membership in Kerala (in all three regions) stood at 25,061; Bihar with 350,000 and the United Provinces at 328,966, easily eclipsed the state (Krishna 1966). The Congress Party had acquired a mass base in most other provinces by 1921. In marked contrast to regions such as Gujarat or the United Provinces, where Gandhi had led powerful movements against the payment of land revenue to the British state, the civil disobedience movement that Gandhi launched in 1930 was a relatively quiet affair in Kerala. In Malabar, the underlying tenurial arrangements precluded such campaigns. The landlords (jenmis) who paid revenue to the state were the only class that would have been interested in such a campaign, but the Congress Party was dominated by middle class Nairs during the 1920s, who were hostile to the landlords. In this respect, the weakness of the Congress Party in Kerala derived from the underlying structural relations - it rapidly became an organization devoted to the concerns of a rising tenantry, whose anti-colonial 'interests' were not as pressing as those against the landlords. In other words, there was no 'predetermined' rationale for the predominance of an anti-colonial interest led by the landed aristocracy or a rich peasantry, which would have overshadowed of the agrarian concerns of the lower tenantry and poor peasants (as in Bihar or the United Provinces). ${ }^{14}$

In Malabar, the Congress Party was during this period primarily engaged in picketing and boycotting liquor and cloth shops that sold British merchandise, and in hunger strikes. In 1930 the Kerala Pradesh Congress Committee (KPCC) reported a number of problems with the civil disobedience campaign including 'fear among the masses, indifference among the rich and landed aristocracy', and state repression. The report stated that Congress activity was being hampered by the arrest of large numbers of leaders and office bearers in the Congress Party (AICC file G-107, 1930). Colonial authorities had prohibited the picketing of all shops, and members were repeatedly arrested after attempting to picket local merchants selling foreign cloth or toddy. The Congress Party continued to lead protest campaigns, interspersed with periods in which a number of its members were imprisoned. By 1932 most members of the KPCC were in jail, and practically no village or district organizations were functioning (there were five District Congress Committees (DCCs) in Calicut, Cannanore, Cochin, Travancore and Palghat). By 1933 the only assets of the Congress Party were 'a chair and table in a corner in the building of the nationalist daily the Mathrubhoomi' (Krishnan 1971: 25). This situation constituted a potential branching off point in Malabar. With the proposal of a temple entry bill in 1933, and the Nair Regulation Act of 1925, which permitted the partition of joint-family property, the Tiyya and Nair caste associations had been granted their demands.

There was in fact no interest among the dominant classes in an anti-tax movement because the British had granted land reforms to the dominant caste (Nair) intermediate tenants, and landlords simply passed on the costs of increased taxes to tenants below them. The context for far-reaching tenancy reforms was established by the Muslim tenant rebellions in south Malabar, in the mid- 
nineteenth to early twentieth centuries. These repeated, violent and suicidal attacks upon Namboodiri landlords and colonial officials so terrorized the British that by 1880 a number of important state officials were debating the necessity of tenancy reforms in Malabar. William Logan, the District Collector of Malabar, argued that the entire edifice of colonial rule in Malabar rested on a faulty understanding of the relationship between landlords and tenants in the precolonial era. During the early twentieth century, petitions from intermediate Nair tenants poured in from across Malabar to extend prior piecemeal reforms. The tenancy question became a crucial hook for the (until then) inactive Congress unit of Malabar. Intermediate tenants seeking permanent occupancy rights began to fill the Congress Party and use it as a vehicle to make increasingly bolder demands for tenancy reform. Although they campaigned against landlord evictions and illegal levies, their primary motive was to secure a higher share of the rent for themselves.

The efforts of the 'intermediate' tenants, who lobbied the Madras government behind the scenes, and used newspapers and various other public forums to consistently press their cause, had proved successful. The Malabar Tenancy Act (MTA) of 1929, a radical piece of legislation for its time, gave them permanent occupancy rights, forbade evictions and reduced the fee that tenants had to pay when renewing their leases. As the introduction to the Act stated: 'The present act is singular in some respects. This is the first instance in this Presidency, and I am not aware of any other cases in other Provinces, where land not permanently settled has been brought under the operation of tenancy rights', (Malabar Tenancy Committee, 1929). In effect, the MTA created a class of 'new' landlords, who joined the ranks of the 'older' landlords, albeit after considerable struggle with the latter (Panikkar 1978). The intermediate tenants had defeated the landlords through the Congress Party, but their success at winning full occupancy rights removed their immediate interest in participating in the Congress Party as a class. After winning a landmark legislation, the Malabar Tenants' Association (Kudiyan Sangham) withdrew from the Congress Party, essentially leaving it an 'empty shell'.

Indeed, the prior organizational weakness of the Congress Party - in part deriving from the behaviour of the landed aristocracy - could itself be a possible explanation for the ascendancy of the CSP. During the 1920s, while the Congress Party was at the height of its expansion across British India, it was a small, comparatively weak organization in Kerala. The Congress Party first set up its branch in Malabar as late as 1922 (compared with the mid to late 1880s in other states such as Bengal, Bihar, the United Provinces and Madras). In the princely states of Travancore and Cochin, the Congress Party never fully established itself due to a policy of non-interference in the princely states (which it maintained until 1938).

In comparative perspective it is clear that had the landed classes in Kerala put up more political resistance within the Congress Party, at the very moment at which the CSP was attempting to gain ascendancy, it (the CSP) might not have 
attained the success it did. How, then, can we disentangle the effects of the CSP's own strategy and tactics of struggle upon its ascendancy? The following section attempts to measure the effects of these practices.

\section{Political practices and historical 'turning points'}

The decision to form a regional unit of the Congress Socialist Party by leftist Congress Party members and social reformers in Kerala was a crucial event that had decisive effects on their political ascendancy and eventual hegemony. At the pan-Indian level the CSP was formed as a faction within the Congress Party in 1934 in the context of growing weariness with mainstream Congress politics, and the immiseration wrought by the Depression. The British government had shown few signs of compromising with the Congress Party, and sought increasingly to use repression to quell discontent among ordinary people, despite the Congress Party's attempt to launch a mass movement after 1920. Political reforms offered by the British (in the form of the Montague-Chelmsford reforms ${ }^{15}$ ) disappointed many nationalists, and the more 'extremist' wing of the Indian National Congress began to take hold within the party as well as outside it.

In 1934 a leading socialist, Jayaprakash Narain, formed the Congress Socialist Party among a group of young, disillusioned Congressmen in prison in northern India (United Provinces). The pan-Indian formation of the CSP represented a crucial historical opening for the building of a mass movement on the basis of class demands, and was a significant political turn within the nationalist movement. By seeking independent and united fronts with mass peasant and workers' organizations, it challenged the overall political tendencies of the Congress Party, the Karachi Resolution notwithstanding (see p. 71). At the first annual meeting held in December 1935, the CSP agreed on a strategy to create 'a gradual and, as far as possible, amicable change ... in the composition of its [the Congress] leadership and its programme ... [to bring about] ... a complete reorganization of the Congress from the bottom upwards' (Rusch 1973: 176). They would set up parallel offices to those of the Congress in each and every district, work on enlarging Congress membership, particularly by drawing in mass membership from peasants and workers' unions, and force the Congress to attend to their demands. In addition, it was decided that the CSP would link independent peasant and workers' organizations to the Congress Party. The CSP would thus exist as a peasant- and worker-based party parallel to the Congress, gaining strength independently within the Congress Party, while at the same time functioning autonomously from it. The Congress Socialists believed that in course of time this strategy would effect a wholesale transformation of the Congress Party.

It is important to recognize that it mattered whether an activist belonged to the CSP or to the Gandhian wing of the Congress Party. The latter felt in no small measure threatened by this new radical formation, viewing it as divisive and factional, but also a serious challenge to the Congress's programme. It also 
mattered whether an activist at the time belonged to the CSP or the CPI, until the CPI adopted a policy of United Front with the left wing of the Congress, that is, the CSP. As discussed earlier, the legal framework of the British colonial state rendered a mass-based revolutionary strategy next to impossible, for its policy of granting successive political and economic reforms, and willingness to abandon its allies among the large landowners, itself influenced the type of strategy that the Congress Party sought. The success of Gandhi's strategy must be attributed to his recognition of the possibilities of building a mass movement within this framework. Because the CSP was a recognized faction of the Congress Party, the British were more inclined to accommodate its activities than those of the Communist Party (CPI) (indeed out of fear of the latter's popularity). Thus while both parties, the CSP and the CPI, were committed to 'anti-feudal' and 'anticapitalist' struggles in theory, in practice the former had legality whenever the Congress Party had legality, and could thus function visibly during many critical years when Indian 'political society' was expanding. In contrast, the CPI was illegal (from 1934 until 1941) and was therefore forced to work underground. The British were entering negotiations with the Congress Party over constitutional reforms that would allow Indians some measure of self-government, and the CSP could avail itself of the opportunity that membership in the primary nationalist organization gave it. On the other hand, the communists, whose preferred tactics until 1935 were violent ambushes and bombings of colonial officials, and whose spreading popularity terrified the British, were increasingly subject to repression.

The Kerala unit of the CSP held its first meeting in Calicut, northern Malabar, in May 1934. Many of the members were actively involved in anti-caste movements, but were now looking for a broader political framework. Thus, in one leading activist's words:

the objects for which the radicals among the social workers strived hard, came to be realized and recognized by the community. [Among] the questions that came up before the social reformists at this time [was] ... was it not time to ask for a casteless social order as a broad objective for all communities?

(Namboodiripad 1976: 149)

Namboodiripad's recollection here, on the other hand, also indicates the broad vision of the incipient CSP. The search for a 'casteless new order' and 'new movement ... encompassing all communities' necessitated appropriate strategies and tactics. The Fundamental Rights Resolution at the Karachi Congress in 1931 formed the basis of the CSP's conviction that the Congress Party could become a mass party based among workers and peasants. As Namboodiripad recalls, 'there was no doubt that if such a monolithic political organization like the Congress would be honest to its own resolution, that could go a long way in strengthening the relation between the Congress and the vast body of the labour and peasant populations' (ibid.). This decision also meant explicitly rejecting alternatives 
such as the Communist League in Trivandrum, southern Travancore. Although they

had [a] better understanding of the basic tenets of socialism than us...they had not yet made any beginning to organize workers' unions or peasants' unions even in their rudimentary forms. They also did not have any plan to strengthen the Congress and utilize it as a tool to consolidate the workerpeasant movement. That way they were not even successful in building up a broad based communist movement even in the vicinity of Trivandrum, the centre of their activities.

(ibid., my emphasis)

The fact that the social reformers in Kerala joined the CSP in the first place, and then used it as a vehicle to press for a new form of politics was itself significant. In rejecting alternatives like the Communist League, the Congress Socialists in Kerala chose to create a mass or popular movement. But, as they recognized, the possibilities for building a mass movement were inherently linked (for better or for worse) to the nationalist movement. For there was an inherent paradox: on the one hand, the hegemonic organization, the Indian National Congress, suppressed popular radicalism, but on the other, it was the only potential vehicle for generating a mass movement. In Kerala, CSP members, although influenced by the ideas of 'terrorist' breaks with 'passive resistance' in the Gandhian mode, nevertheless recognized that individual acts of terrorism could never supplant the tactics of mass movements (interview with peasant leader K.A. Keralaeeyan in Gopalankutty 1989a: 179).

The communists, on the other hand, either did not understand this paradox or refused to operate within its scope. The Gandhian 'cloak', declared the CPI in 1930, concealed the fact that the Congress preached and defended the 'interests of the Indian capitalists, the inevitability and the wisdom of the division of society into rich and poor, eternal social inequality and exploitation'. In 1930, as civil disobedience movements were drawing thousands of Indians into the nationalist fold, the CPI called for a 'general national armed insurrection against the British exploiters and all their allies in our country' ('Draft Programme of Action, 1930', in Karnik 1957). In Bengal and Punjab, where their influence was particularly strong, communists attempted assassinations of colonial officials and raids on treasuries, alarming the British colonial regime into taking swift, repressive action. Thousands of communists were jailed during the 1920s and 1930s, at a time when the Congress-led nationalist movement was picking up momentum. This factor alone is of enormous historical significance, for it meant that despite favourable 'objective conditions' in many parts of the country, class was not emerging as a salient fissure within the nationalist movement for want of a cohesive and available leadership.

It must be emphasized - somewhat paradoxically - that while Kerala's Congress Socialists and Indian communists were in implicit strategic 
disagreement, ideologically they were not all that far part. Indeed, just like the communists, the Kerala Congress Socialists distinguished themselves very clearly from a Gandhian nationalist position - they made public statements denouncing the non-violent stand of Gandhian nationalists, and adopted and passed resolutions within the Congress Party not to enforce the wearing of homespun cloth (Menon 1994; Namboodiripad 1976). Congress Socialists in Kerala increasingly maintained close links with the CPI, and in 1937-38 a few of them secretly joined the CPI, intending to fold into the latter party at an opportune moment (this moment arrived when they were ousted from the Congress party in 1940). What distinguished them from the communists in other parts of India was their tactical use of the Congress Party as a cover for their activities, and a commitment, for tactical purposes brought about by a reading of the situation, to the idea that violence would not achieve the ends of creating a broad-based movement.

This tactical understanding might not have mattered, however, if it were not for key 'objective' factors that made this choice a viable one. While leftist dissent in the Congress Party drew a number of its leaders and activists into the fold of the CSP (active CSP branches existed in the United Provinces, Bihar, Andhra Pradesh and Bengal), the specificity of CSP formation in Kerala compared to these regions lies in the relationship between the underlying objective conditions and party strategy. First, the viability of a political agenda of nationalism that combined with protest against landlordism from within the Congress Party, was made possible by the weakness of dominant class representation within the Congress Party. Not only does comparative evidence bear this out, as I will subsequently discuss, but this was explicitly recognized by the CSP - "[the dominant classes] did not at this stage openly oppose this programme. ... They had ... an eye on future elections for which a vague peasant programme was useful. Their attitude to it was, therefore, one of benevolent neutrality' (Namboodirpad, undated). The comparative evidence, however, of repeated obstruction of the left by organized groups of landlords and dominant classes within the Congress Party units of Bihar and the United Provinces in particular, presented later, gives us a sense of how important its absence was for the CSP to work relatively uninhibited within the nationalist organization. A second factor was the prior involvement of many CSP members in caste reform organizations and the Congress Party. This dual experience set them apart from leftists in other regions of India, many of whom were inducted into the Communist Party of India at its formation in 1925, and openly declared war on the colonial state and the Congress Party. Inadvertently perhaps, the CSP in Kerala avoided the 'ultraleftism' of the CPI, and its consequent near decimation; as K. Damodaran, a leader of the movement, recalled, '[w]hen people ask me why the CPI became so strong in non-industrialized Kerala as compared to Bombay, I reply that the main reason was there was no CPI in Kerala in the 1930-33 period and so it was possible to start anew' (Damodaran 1977). 
The historical 'advantage' of forming a CSP rather than joining the CPI in 1934 was no doubt also reciprocally related to conditions in Kerala; in particular, existing social relations and constituent struggles had imposed a 'steel frame' on future political possibilities (Zeitlin 1984: 216). Thus no leadership that sought to win a mass base could ignore the possibilities inherent in the caste movements; but more to the point, the upper caste youth involved in caste reform movements possessed a 'grammar of protest' that informed their future political choices. Their own experiences in grass-roots organizing against untouchability lent them a proclivity for grass-roots forms of mobilization. For instance, the CSP's activities included forms of protest such as 1,000-mile-long processions (jathas), public meetings in town squares and consciousness-raising in reading rooms tactics which had been employed by caste organizations for over three decades, and which were highly visible and public. In Bengal, in comparison, although a communist party also gained ascendancy, its origins were less associated with mass movements among the poor. Thus a comparatively less hierarchical caste structure, and the lesser degree to which caste movements had developed, affected the very form in which the left organized - its strategy of dissociation from the Congress Party derived on the one hand from the much stronger dominant class representation within the party, but on the other, its tactics of violence both derived from, and reinforced, the absence of connection to mass movements among poor, lower caste workers and peasants.

\section{Party as movement: Congress socialist tactics in 'civil society'}

If the weak political organization of the dominant landed classes in Kerala gave the CSP a structural advantage as a faction within the Congress Party, this factor belied their continuing strength in 'civil society'. This concept must be employed with several caveats, for its frequent evocation is often in direct proportion to its vague generality. Nevertheless, separating the two spheres of 'civil' and 'political' society is conceptually useful, for it denotes the extent to which inequalities persist in non-state domains despite their legal-political negation. While landlords and dominant upper caste peasants in Kerala eschewed a classbased political interest within the nationalist movement and organization, they continued to exert their dominance through the interrelated practices of landlord evictions, caste segregation and untouchability, and demands for illegal levies. These arguably worsened in the immediate post-Depression years (Malabar Tenancy Committee Report, Madras (Presidency) 1940). Landlords denied tenants the use of common lands, even as the food crisis worsened (Menon 1994). Despite the proliferation of lower caste associations, caste-based restrictions on the use of temples, public roads, and various practices of untouchability continued unabated. Numerous instances of violence on the part of individual landlords were documented during this period. Even as late as 1940 the Malabar Tenancy Committee was forced to remark on the persisting control of the landlords or jenmis over their under-tenants. The Report repeatedly emphasized 
the need for giving fixity of tenure to the verumpattomdars or tenants-at-will in order to avert further deterioration of their living conditions (ibid.).

Undoubtedly, by 1940 tenant insurgency had grown to such an extent that the British were forced to admit the depredations of numerous intermediaries, and argue in favour of 'fair rent'. But such a movement did not arise spontaneously. The CSP's strategy of forming class associations, which differentiated it from all prior lower caste associations, meant that the socialists employed tactics of struggle aimed at cross-caste alliances among tenants in rural Malabar where agrarian relations were in crisis. Moreover, employing a theory of the importance of class struggle within the anti-colonial struggle, they also accordingly shifted the focus of prior Congress activity from the traditional town-based picketing of merchants and boycotts of British goods. In 1934, at the time of the CSP's formation, there had been no autonomous movement of lower caste tenants in Malabar. In 1934-35 the CSP initiated local, targeted struggles against landlords in Malabar. The CSP recognized that weakening the structure of landlordism required attacking the daily enactments of tribute and obeisance to the lords as much as it required an 'economic critique'.

To pay attention to the historically situated process of organizing is key to understanding the effects of the CSP's practices at that historical moment upon their ascendancy. Since the CSP leaders were overwhelmingly upper caste, a prior necessity for organizing was to break the caste barriers between the organizers and the organized. Thus, to defy in practice distance pollution, the use of selfdenigrating speech by the low caste tenants, prescribed modes of dress, and generally the implied barrier between purity and pollution of upper by the lower castes, was both the CSP's tactic and its effect. The high caste Congress Socialists would go from door to door, entering peasants' houses and eating their food. Such instances of common eating and sharing the same floor space was unheard of, and created a virtual 'social revolution' in the villages of north Malabar. Breaking down caste barriers was also an important theme at peasant rallies. At the first large peasant conference held in a village in north Malabar in 1936, for example, the CSP organizers adopted two major resolutions: (1) to abolish customs and speech usage that were demeaning to low caste labourers and (2) to abolish feudal levies (Menon 1994). These resolutions struck at the core of the caste system, and fused in one movement demands for human dignity and protest against the material relations of domination and extraction.

Although upper caste reform leaders had been active in the three regions of Kerala for a decade prior to the formation of the CSP, the CSP first broke apart the upper caste councils, transforming them from a traditional caste-based corporate group into a site of radicalization (Kurup 1988). These ritualistic caste associations were controlled by the dominant landowning families, but when members of the younger generation became politicized they successfully began to use them to organize tenants in the villages. Indeed, as Menon has shown, upper caste CSP leaders were often the only ones who could enter the houses of landlords, with others down the caste hierarchy forbidden from entering the 
grounds. Or, put another way, the CSP leaders used their own privilege and structural location to attack the 'structure' of caste-class relations. Conversely, this tactic of struggle recognized the possibilities for transformation from within the caste structure itself.

The practices of Kerala's Congress Socialists, and the knowledge and experience required to develop them did not emerge overnight. The Congress Socialists used existing repertoires of caste protest, borrowing many familiar tactics such as long-distance processions or opening reading rooms. Reading rooms had a tradition dating back two decades, used by caste associations to promote caste equality and the virtues of literacy. But the CSP transformed these rooms into nodes of politicization linking the three provinces of Kerala in an extensive network. Reading rooms and night schools for peasants were opened when new district branches of the CSP were created (for a few examples, see The Hindu 1935, 1 July, 6 July and 29 August).

The inheritance of caste protest and the organizational form of Congress nationalism affected the practices of the left in Kerala; this factor is revealed only through comparative analysis. As will be discussed at greater length in Chapter 5, in Bengal, communists did not inherit (or were not embedded in) ongoing caste movements or mass movements as powerful as those in Kerala. In part structurally driven, and in part driven by an economistic strategy that failed to fully tap the potential for radicalism in colonial Bengal, communists focused largely on urban workers' strikes and wage struggles in the jute and railway industries, with pockets of rural activity among sharecroppers (Bose 1986; Franda 1971). The comparison with Kerala shows how different the results were - while the CSP commanded a sizeable portion of the Congress membership (from roughly 4,000 in 1934 to 50,000 in 1939) with branches in rural and urban areas of the three provinces (Gopalankutty 1989a and b), the CPI in Bengal, with a membership of approximately 1,000, was regionally confined to three out of fifteen districts of Bengal by the 1940s (Bhattacharyya 1978).

\section{CSP, working class protest and the princely states}

Although worker militancy was growing across British India and the princely states during the mid- to late 1930s, it was largely conducted outside the ambit of the nationalist movement. During the 1930s workers across India had begun to strike in large numbers in the aftermath of the Depression. Between 1931 and 1934 in all of India there were a total number of 589 industrial disputes involving 716,853 workers with a loss of 11,275,080 working days (Revri 1972: 191). The number of disputes had been increasing every year. In 1936, when the Depression lifted, the number of strikes actually began to increase. While the annual average number of strikes between 1924 and 1936 was 147, in 1937 and 1938 the numbers rose to 379 and 399 respectively across India (ibid.: 217).

At this particular historical moment, the CSP's tactics in Kerala compare favourably with those of left parties in other parts of India, and reveal a different 
picture of the relationship between Indian nationalism and worker protest. In the princely states, the CSP linked struggles against the princely state, colonial capital and the upper castes in a single movement that was based largely among the workers in coir factories, toddy-tappers, agricultural labourers and workers in the informal sector. The insurgent movements in Travancore began in particular after the CSP 'took over' the leadership of the Travancore Labour Association (TLA, an employer-created welfare organization) in 1934. The presence of a large floating population with simultaneous rural and urban ties was a significant factor in accounting for the rise of class consciousness and militant struggle (Jeffrey 1984). Ideas, experiences and stories of successful strikes and other industrial action could travel across the two milieu, easily creating a strong sense of solidarity. In addition, however, the presence of two political conjunctures during the late 1930s was critical in decisively pushing the TLA and the nature of workers' struggles and demands in a radical direction. First, the CSP imported new strategies and tactics into the TLA by seizing upon the Depression conditions to justify demands for a halt to cuts in wages, provision of unemployment, oldage and sickness benefits, regulation of wages, elimination of sub-contracting of work and an end to petty exactions and retrenchment (Kannan 1988). The new leadership of the TLA also linked these economic demands with the political demand for Responsible Government ${ }^{16}$ in Travancore. The CSP not only unionized coir workers, boatmen, sweepers, cashew workers and toddy-tappers; they also used this base to rival the moderate Travancore State Congress (TSC) to campaign for Responsible Government. ${ }^{17}$ The CSP was more consistent than other organizations in projecting a nationalist and progressive identity. They were thus able to legitimize themselves among their constituencies as the more 'authentic' leadership in comparison with the middle class politicians of the State Congressmen ('it was this [betrayal of the workers] that brought us to the logic of having a Communist Party', wrote M.C. Govindan Nair in the late 1930s, quoted in Jeffrey 1976: 469). In 1938 CSP members from Malabar travelled to Travancore and together with the militant Youth Leaguers organized a strike of boatmen and coir workers in which an estimated 200,000 workers participated (Oommen 1985). By 1940 most of the leaders and organizers of the strike had become members of the Communist Party of India. The TLA, which had become the Travancore Coir Factory Workers' Union (TCFWU), was now controlled by the communists.

\section{Further specifying Kerala's left ascendancy: nationalism as the terrain for a 'violent' strategy}

The narrative account of the growth of radical working class and tenant movements in Kerala could yield the somewhat false impression that such activity was restricted to Kerala. As with the growth of working class protests and organizations during the 1930s, poor peasants across India were becoming increasingly assertive. In 1936 left peasant leaders formed the All India Kisan 
Sabha (AIKS) at the national conference of the Congress Socialist Party in Meerut, United Provinces. Their stated aim was to organize peasants against the zamindari system (landlordism), and abolish the various systems of landlords in existence across British India. By the time of their annual conference in 1938, membership of the AIKS stood at 546,800. Of these, 250,000 were in Bihar, 34,000 in Bengal and 60,000 in the United Provinces (Rasul 1969). The picture in Kerala was in fact somewhat mixed. In Malabar, despite the enormous success of the AIKS in establishing a branch in the northern districts, this was matched by its failure to establish support either in the southern districts of Malabar, or among owner-cultivators in Cochin and Travancore. Thus, in order to establish further the specificity of the Kerala CSP's strategies and tactics in Kerala, we have to ask what the leaders did politically with their social base, that is, how they established themselves as a political force (which itself was derived from the Kerala CSP's class hegemony) within the nationalist movement in Kerala.

Ideologically, Gandhi had attempted to enforce a commitment to 'non-violent' methods of struggle. The term 'non-violent' did not refer only to the abstention from the use of physical force or 'terrorist' methods: by emphasizing self-help, spinning and weaving of handloom cloth, wearing hand-spun cloth (khadi) and peaceful civil disobedience, Gandhi attempted to give cultural meaning to 'passive' struggle. In contrast, 'violent' methods were the 'small battles on local and specific issues against capitalism in the villages' in which Gandhi advised workers not to 'fritter their fighting strength ..., but to concentrate on peaceful khadi work' (Tendulkar 1951: 20). ${ }^{18}$

In Kerala, during the mid- to late 1930s the CSP converted the Congress Party into a terrain of struggle between the 'left' and 'right' factions over the question of strategy. This battle was fought in ideological/political terms as a question of Gandhian vs. non-Gandhian strategy, that is, as a question of whether to emphasize self-help activities such as spinning and weaving, and the wearing of hand-spun cloth by Congress members, and rural constructive programmes, or whether to unionize peasants and workers, demand an end to illegal levies from tenants, and strike for better wages and working conditions. Because the 'left' within the Congress Party in Kerala represented a clear class organization of poor peasants, agricultural labourers and workers, and the 'right' did not represent the political and economic organization of the dominant classes, these battles became the crucial tactics through which the 'left' CSP secured political hegemony over the nationalist movement. These tactics linked anti-colonialism with the 'local and specific battles' against landlordism, monarchical rule and British capital and brought it to the centre of Congress Party activities, thus increasing the mass nature of the Congress Party in Kerala.

In early 1934 membership of the KPCC stood at 3,000. Through Congress Socialist organizing, another 5,000 members had been enrolled between May and July (The Hindu, 16 July 1934), a phenomenal increase when we consider the fact that Congress Party membership in other regions, such as Bengal, was declining. The number of Congress members continued to rise as the Congress Party 
activated its district and village level offices from the mid-1930s. By June 1938 the membership of the Congress Party was 60,000 (Fortnightly Rreport, 24 June 1938, cited in Kunhi 1993: 99). This was the effect of the specific policy of CSP leaders who enrolled peasants simultaneously in the karshaka sanghams (peasant unions) and the Congress Party (Gopalankutty 1989a: 206). The Congress Party, in other words, became the site of the political expression of the growth of class organizations in Kerala. In 1938 the Congress Socialists won a majority of the seats in the Kerala Pradesh Congress Committee elections. With their increasing success at forming class organizations and thus a mass base, the CSP leaders took the ideological battle against Gandhian 'non-violence' to public meetings and demonstrations (AICC file, P-11, 1410, 1940). In 1939, in growing alarm, some prominent 'right' Congressmen formed the Gandhi Seva Sangham that continued to function within the Congress Party much like the CSP. It was a direct response to growing leftist 'audacity' within the KPCC. The degree to which the KPCC had deviated from the working of the Congress elsewhere is evident from the material that was taught at meetings, volunteer camps and study circles held by the CSP. Camp attendees were taught about the revolutions in France, Russia and China, the 'Working Class Movement in India', the 'Labour Movement in Kerala' and 'Progressive Movements in India' (AICC file, P-12 (Part II), 1938), which as an All India Congress Committee Report (AICC) noted, 'taught more on class wars than on Satyagraha and constructive programme' (AICC file, P-11, 1410, 1940). The volunteer movement, an AICC report (AICC file, P-12, 1939-40) noted, was particularly strong in the Malabar district, with 1,348 volunteers helping in 'bringing the Congress organization in closer contact with the masses'.

This simultaneous party/movement development, in particular, under the aegis of a left party, was a distinct anomaly in British India. The extent to which the Kerala CSP was recognized as a contender within the Congress Party was stated in a British government report as follows: 'The Kerala Congress Province is leftwing and unruly - as little amenable to Congress discipline as to Government' (National Archives of India, 20 September 1940). In the 1940 elections to the Malabar District Board, the struggle between the Gandhi Seva Sangham and the CSP came to a head. The Sangham called on all its members to boycott the elections. Prominent members of the Sangham, such as the Malabar industrialist Samuel Aaron, went from door to door canvassing votes for anti-Congress candidates. 'Old' Congress stalwarts like Kelappan and K. Madhavan Nair, and numerous other Congressmen wrote letters to the All India Congress Committee detailing the CSP's 'total abandonment of the Gandhian programme'. They also alleged that the CSP had not entirely played by the book in obtaining a majority in the KPCC. Likewise, the Working Committee of the KPCC, dominated by the 'left', complained of considerable foot-dragging by the subordinate committees who at the time openly defied the decisions of the Working Committee (ibid.). In 1940 the Working Committee of the Congress appointed a committee to 'enquire into complaints of indiscipline, etc., brought against the Kerala Provincial 
Congress Committee or its members'. The Committee's finding was that 'the majority obtained by this bloc is not a genuine majority but has been manufactured by the clever gerrymandering of the constituencies'. It recommended 'that the present committee should be superceded and a person or persons of the province be appointed to carry on the work of the province' (AICC file, P-11, 1410, 1940).

By now the CSP leaders, E.M.S. Namboodiripad, A.K. Gopalan and P. Krishna Pillai were making clandestine contacts with the CPI and forging a closer working relationship. In large part this was a direct result of the policy of the national-level CSP leadership at the Second Conference of the CSP, in 1936, to enter into an alliance with the CPI. In 1935 R. Palme Dutt and Ben Bradley (both members of the Communist Party of Great Britain (CPGB) wrote about the presence of a progressive element within the Congress Party that was strongly anti-imperialist and thus posed the possibility of a strategy of a 'united front from below'. They argued for the possibility of transforming the Congress from within, for which four conditions had to be met - Congress would have to be made to: (1) accept 'collective affiliation', i.e. the collective admission of mass organizations; (2) democratize its constitution; (3) demand complete independence with a 'democratic' government; and (4) eliminate the 'dogma' of non-violence. Dutt and Bradley also specified that left-wing unity in the Congress was to be attained through the medium of the Congress Socialist Party (Overstreet and Windmiller 1959: 160). At the next conference at Faizpur, United Provinces, in 1937 there was increased cooperation between the CSP and CPI, and a definite communist faction developed within the National Executive of the CSP. During the next three years communists succeeded in capturing control of CSP units in several states, and almost succeeded in capturing control of the National Executive itself. This 'external' event (the CSP-CPI pact), and through it the increasing influence of the CPI on the Kerala CSP, further reinforced the split and antagonism between 'left' and 'right' formations in the Kerala Congress Party. But the unilateral dissolution of the Kerala Congress Party by the national leadership forced the hand of the CSP, and in 1940 they joined en masse, the new underground party unit of the CPI.

\section{CPI strategy in Kerala, 1940-47}

The near-famine conditions in Travancore during and after the Second World War have been alluded to in the previous chapter. During this period the communists had renounced their isolationist policy, declaring the war to be a 'Peoples' War' once Britain entered it against Germany. As a consequence of this position, the British lifted the official ban on CPI activities, extracting a perhaps rather meaningless promise from the party to refrain from 'agitational' activity. In Kerala, communists had already established a strong base in the three regions, but the ensuing period was by far their most insurrectionary - and thus deviated from the national policy. In the coir industry, despite the recognition awarded to 
unions, a Government of India report in 1946 had referred to the low earnings, poor working conditions, insecurity and the absence of medical care for workers in Travancore. Communists continued to organize in the coir industry, agitating for better conditions and higher wages. Between 1946 and 1947 there were some shifts within the CPI leadership in Kerala, and although the emergent leader E.M.S. Namboodiripad, who was to forge the centrist line within the CPI, was arguing that the Kerala Congress Party was a progressive party, he and others accepted the new insurrectionary Ranadive line (see p. 96) against the new Indian Congress-led government. This had important consequences in Travancore in particular, where despite the land reforms which had benefited numerous tenants, agricultural labourers continued to live in degraded conditions, treated no better than serfs. Communists had been unionizing the agricultural labourers in the "rice bowl' of Kuttanad (Travancore) and had called for the equal distribution of land to all the tillers of the soil. It must be noted here that the demand for land for agricultural labourers, indeed their political organization, was radical and generally not taken up by peasant organizations across India for fear of splitting the peasant movement. Utilizing its base among agrarian and coir workers, the CPI led a strike, which was met with fierce repression by the Dewan. On the second day of the strike, after one demonstrator had been shot, 2,000 strikers attacked a police station in the famous Punnapra-Vayalar uprising. The idea was to create a 'liberation zone', but some supporting parties (including the Travancore State Congress) pulled out and the uprising was crushed. While many communists were killed in the ensuing repression (figures range from 300 to 500 ), it allowed the CPI to 'stake its claim to be in the forefront of the struggle against absolutism' (Nossiter 1982: 92).

In 1946, as Cochin joined the Travancore state, there was a renewed discussion about the idea of a Malayali Kerala state, that is, a united state that would be based upon the growth of Malayali cultural revivalism. The CPI's active involvement in this movement for state unification - a specifically cultural movement - undoubtedly also added to its ability to win hegemony. The communists pitted this movement against the United Kerala movement, which envisaged a larger multilingual province based upon what they viewed as a 'feudal-militaristic' myth of an empire created by the lord Parasurama (Namboodiripad 1952). The upshot was that the communists succeeded in using this movement to link concretely with the reading rooms that existed in every village where Malayali literature was stocked along with a range of socialist and progressive literature with titles like From the Gutter, Scavenger's Son and Two Measures of Rice.

\section{The 'intra-class' struggle: strategic cohesion among Kerala's communists}

The struggle over the definition of class - or other social cleavages - is also an 'intra-class' struggle over who gains leadership of the struggle (Stepan-Norris and 
Zeitlin 1989; Zeitlin 1984). In Kerala, the merger of a socialist and communist party (in 1939) marked the succeeding struggles and party formation in the state in unique fashion. When the CSP voted to join the CPI in Kerala, there was only one dissenting vote (Nossiter 1982). This represented a degree of cohesion in strategy among its core leaders not to be found in other regions. It is difficult to posit a singular reason for this cohesion; however, there would appear to be a strong structural reason for why the CSP's folding into the CPI was a strategy that was appropriate to the underlying structural conditions.

Ironically, in many ways the CSP was not ideally placed to carry out a cohesive strategy. Despite its position as a faction within a legitimate party, it was a loose amalgam of ideological opposition to the Congress Party rather than a disciplined and cohesive party. Indeed, a glance at the national leadership of the CSP gives cause for surprise that it was the same party that achieved so much in Kerala. At the national level, apart from a vague commitment to 'class struggle', Congress Socialists did not unanimously agree on strategic matters. The top ten founding leaders of the CSP were drawn from a range of ideological tendencies that included the social democracy of the British Labour Party, and a variety of socialisms, some of which drew upon Gandhi's concepts of decentralization and non-violence (Chaudhuri 1979). They did not agree on whether Marxism was to be a 'useful method of social analysis and nothing more', or whether the CSP should fashion itself as a Marxist-Leninist party. While their goal remained to capture and penetrate the Congress Party, members were exhorted "not to show keenness to "capture" committees and offices [of the Congress] nor ... form alliances with politically undesirable groups for the purpose'. Such ambivalence towards the Congress Party was reflected in the very small number of regional party units that successfully challenged the hegemony of the Congress Party. The only other case where the CSP came close to the position of challenging the dominance of the 'right' Congress was in the state of Bihar. What factors prevented it from succeeding?

\section{Bihar: CSP, CPI and the 'intra-class' struggle}

The rise and demise of leftist insurgency in the north-eastern state of Bihar during the 1930s is an important test for ascertaining how important ideological and organizational cohesion were for the fortunes of the party, and the extent to which these factors were relatively autonomous from underlying structures. Indeed, Bihar appears to have a longer history of peasant rebellions independent of the advent of modern parties, than in Kerala. Rebellions such as the Santhal Rebellion 1855-56, the Munda Uprising 1899-1901 and the Indigo Riots of 1867, 1877 and 1907 in Bihar were caused by a number of factors, but they reflected a history of rebellion against the colonial state and landlords. These rebellions continued well into the twentieth century. In a story that is by now familiar in the case of Kerala, the Depression crash of the 1930s formed the underlying conditions for these rebellions. Landlords had begun taking over 
bakasht lands, that is, land held in the 'cultivating' possession of landlords. The economic conditions were grim, particularly as one went down the social hierarchy. Prices of commodities had crashed and agricultural labourers were forced to accept wages in kind rather than cash. The demand for labour had decreased, and sharecroppers found their share of the crops worth less and less. Many of them became tenants-at-will in the process; while rich landlords and peasants had sufficient cash reserves to ride out the Depression, tenants found their conditions worsening (Henningham 1982: 141).

During the 1930s, the Congress Socialists in Bihar led a powerful agrarian movement, drawing together tenants and agricultural labourers in waves of land occupancies and anti-landlord protests. The growing scale of evictions and use of short-term tenancies and tenancies-at-will on land occupied by hereditary tenants were the primary mobilizing issues. The Peasants' Association or Kisan Sabha in Bihar began as an auxiliary to the Bihar Congress Party, revived after a period of inactivity in 1933. Immediately, the Kisan Sabha began a rapid organizational expansion, setting up branches in every village and district. Between 1933 and 1935 over 500 Kisan Sabha meetings were held in ten districts of the province, an indicator of the growing popularity of the peasant movement and the growing strength of the Kisan Sabha (Damodaran 1992: 100).

Of particular interest to us is the growing polarization in the Bihar Congress Party, as the Kisan Sabha's activities became more radical; by 1937-38, much as in Kerala, the 'left' and 'right' came to a head over the Congress Party's agrarian programme. The landlords' organization, Zamindar Sabha, alarmed at the Kisan Sabha's challenge to their dominance, registered its 'fear' of the 'advance towards anarchy', citing that 'the importance of our political organization, the Congress, is in danger' (Resolution of the Lalganj Zamindar Sabha, 4 December 1937, cited in Das 1983: 154, emphasis mine). It was no wonder that the landlords were alarmed; the 'left wing' of the Congress, associated with the Kisan Sabha, had been leading mass protests across north and south Bihar, and many tenants had interpreted its message as asking them to stop paying rent (Henningham 1982: 148). Despite active attempts to obstruct the CSP-led Kisan Sabha by Congress leaders, supported by landlords (large and small) and rich peasants (Das 1983; Henningham 1982), Bihar's agrarian movement under CSP leadership developed into a powerful organization (Kisan Sabha) with a membership of 250,000 by 1938 and a set of radical demands that included the abolition of zamindari. ${ }^{19}$

This story forms a distinct parallel to that outlined in Kerala, yet Bihar's trajectory diverged soon after the early- to mid 1940s, resulting in a highly fragmented peasant movement with a very low degree of institutionalization of their earlier demands and radical organization. In searching for the causes of this divergence, a cursory glance at Bihar's history would suggest that the powerful, well-organized constituency of large and small landlords within the Congress Party, and the consequent conservatism of its leadership, might explain the weakness or inability of the left to move forward within the Congress. Scholars 
of Bihar's agrarian movement, and the memoirs of Swami Sahajanand, the leader, document the ongoing attempts by Congress members, backed by the landlords, to quell the growing defiance of the poor peasants (Das 1983; Damodaran 1992; Hauser 1961; Henningham 1982; Saraswati 1940). Numerous tactics of obstruction were used, ranging from blocking delegates to elections to physical violence. For example, through subterfuge of election rules in 1937, members of the 'right' impeded the enrolment of delegates from the Kisan Sabha to the All India Congress Committee, enrolled their own supporters after the deadline and used their own partisans as polling officers (Henningham 1982: 148). In Darbhanga, north Bihar, Kisan Sabha supporters were physically blocked from voting; the result was that the 'right' won the elections and there was no 'left' Congress member appointed to the provincial working committee. Moreover, only five of the thirty-six Biharis elected to the AICC were from the 'left' (ibid.). Of this repeated harassment and obstruction and its result, one party member noted:

In the interest of the cause ... we must get out of the party struggle at least for a year. Kisan problems require our immediate attention. Situation is very critical and serious, how can we leave the kisans, who are being assaulted, murdered, abused and their crops and property looted.

(quoted in Henningham 1982: 150).

The response of the dominant classes, and their use of the Congress machinery to obstruct the growing left-led peasant movement in Bihar is undoubtedly of enormous importance when we compare with Kerala, for in the latter case, landlords and 'rightist' Congress members were unable to obstruct the CSP to any significant degree (until 1940 when they were expelled from the Congress Party). But this hypothesis could be tested and pushed further. In Andhra Pradesh, when challenged within the Congress Party, communists were able to organize an extremely powerful challenge to landlord domination outside it. In Bihar, rightist Congress members had, in fact, severed the peasant association (Kisan Sabha) from the Congress Party, arguing that its activities had become anti-Congress (Saraswati 1940: 271). Why then did the Bihar Kisan Sabha not launch a more protracted struggle against landlordism, with or without the Congress Party?

Once again the answer only emerges in a comparative framework. It appears to lie in the relative weakness of the relationship between left party formation and peasant organization/movement in Bihar, as compared with in Kerala. With regard to Bihar, the historical evidence is replete with incidents of infighting, bickering, indecision and strategic disagreement among the political leaders of the CSP, with whom the Kisan Sabha was first associated. The leader of the peasant movement, Swami Sahajanand, gradually grew disillusioned with the CSP because its leaders were overwhelmingly inclined to adhere to Gandhian, non-confrontational tactics (Das 1983). Branding Sahajanand a 'faction leader', the CSP in effect expressed its bitter animosity towards the communists towards 
whom it (accurately) perceived Sahajanand to be sympathetic. ${ }^{20}$ Unlike in Kerala, where the CSP was largely in agreement about its strategy of critical dissociation from the 'right' Congress, in Bihar such consensus did not exist. Within the Kisan Sabha in Bihar, the push at the local and grass-roots level was far more radical than from the leadership. Thus, although the Bihar Provincial Kisan Sabha leadership had prohibited the forcible occupation of land, frontline activists and tenants were using slogans that called for a more violent approach towards landlords. This put pressure on the Kisan Sabha, which as Damodaran argues, 'ran the risk of being sidelined by a developing mass movement over which it would then have little control' (1992: 109). The disorganization of the leadership, and strategic disagreement among the leaders, prevented it from formulating a consistent and sustained relationship to this developing mass radicalism. The effect of what can be called the 'unresolved intra-class struggle' upon the 'class struggle' in Bihar, then, was one of demobilization and disorganization. The Kisan Sabha in Bihar eventually fragmented into several political parties - CSP, CPI, Forward Bloc - and its membership began to decline by the 1950s (Das 1983).

Comparative analysis with Kerala suggests another key factor - the uniqueness of the CSP-CPI alliance in Kerala, indeed the merger of the two, and the particular effects of this on a coordinated strategy of left party advance. Despite the CPI's conscious decision to work within the Congress Party at an allIndia level from the mid- to late 1930s, in part by allying with the CSP, relations between the two parties were rarely congenial enough to establish a merger. Or, put differently, apart from in Kerala, the CSP elsewhere maintained a much closer attachment to Gandhian tactics, in effect provoking the fury of the CPI. In Bihar, no matter how fierce the criticism of the 'right' Congress, socialists never presented any real alternative to the Congress to their constituency (Damodaran 1992: 112). Sahajanand's disillusionment with the CSP was no different from that experienced by many other leaders of peasant and workers' movements across India, but a single leader was probably in no position to effect an alliance between warring parties.

In seeking to understand why these fragmented practices were 'relatively autonomous' from underlying structures we need to examine the caste-class relations and possibilities for class formation among peasants. In Kerala, the CSP-CPI alliance was made possible by the 'workerist' orientation of the CSP, an orientation which was propelled in no small part by the higher rates of proletarianization in Kerala (see Table 2.4), as well as early working class activity in Kerala. Thus, in effect, the strategic and tactical differences between the CSP and CPI were very minor. It remains to be answered why the leadership of the CSP chose to merge with the CPI in Kerala; one clear reason is that the CPI posed the only clear alternative to those who were weary and sceptical of any chance of social transformation under Congress Party leadership. In Bihar, the colonial transformation of agriculture had not been as deep as in Kerala, and it had primarily resulted in an increased tax burden followed by the intensified 
squeezing of peasants by small and large landlords. The much lesser degree of capital penetration meant the much weaker development of either an agrarian or urban proletariat (Table 2.4 shows that proletarianization in Bihar was practically non-existent). This underlying structural feature explains the centrality of an agrarian programme in Bihar, yet suggests that without a crucial alliance with a working class and a strong workerist party, the combined effects of Congresslandlordism proved too strong to allow a relatively fragmented left leadership to win a significant base and political hegemony.

This fragmentation was further deepened by the CPI's apathetic response to the mass upsurge that developed in Bihar during the Quit India movement of 1942. The adoption of this new insurgent line by the Congress Party in its final push towards independence resulted in the British declaring the Congress illegal and imprisoning its key leaders. In Bihar, this was met with mass protests, especially by students, who took to violence on the streets, hijacking trains, destroying post offices, cutting off roads and railways, cutting wires and attacking police; yet there was no effort on the part of the leading parties of the left to take this into rural areas and organize peasants. As the CPI had adopted the 'People's War' line, they refrained from participating in the revolt - and lost an important opportunity to embed themselves more firmly among the peasants.

\section{Andhra Pradesh (Telengana): CPI strategy and party ascendancy}

Another crucial comparative case is Andhra Pradesh where, as noted in Table 2.3, rates of proletarianization were the fourth highest after Kerala, Bengal and Maharashtra. The 'objective conditions' should predict the influence of strong left-wing organizations in the region. Indeed, the largest peasant insurrection that ever took place in India occurred in the region of Telengana (consisting of nine districts $)^{21}$ in 1948 , and gave the communists a potential chance to embed themselves politically in the region. In particular, it was in the two districts of Warangal and Nalgonda (discussed in Chapter 2), that the Telengana insurrection was most acute.

Andhra is a particularly important test case because here, as in Kerala, communism arose out of the nationalist movement. Most of the soon-to-be CPI members had first been involved in the Andhra Mahasabha (AMS), an organization established by some sections of the Congress Party in 1930. Since Hyderabad was a princely state, as in Travancore and Cochin the Congress was largely inactive as a separate party, and when it attempted to form a local chapter in 1938 it was banned by the Nizam. The organization conducted smaller satyagraha campaigns which were largely unsuccessful, revealing a nationalism much weaker than in Travancore, for example. Many dissatisfied Congressites began to gravitate towards the CPI during the 1930s, as the latter had begun its 'Popular Front' policy of aligning with progressive elements within the Congress Party. In Andhra, the two groups - the Congress Party and the CPI - co-existed within the Andhra Mahasabha for a while, but the relationship between the two 
was acrimonious. In 1945 the Congress members of the AMS sectioned themselves off from the communists and formed a new organization called the Nationalist Andhra Mahasabha. For those who gravitated towards communism, the move appears to have been gradual as it was in Kerala. For example, the most prominent communist member began as an activist in the Gandhian Harijan Sevak Sangh (a Gandhian organization), and as a participant in civil disobedience in 1938 (Roosa 2001: 62). However, the decision to form a communist party unit during the 1940s without the middling phase of joining the ranks of the CSP, marked the Andhra communists' trajectory in specific ways.

After the bewildering twists and turns in communist policy, from Popular Front to the People's War line which involved joining the war effort once Russia entered the Second World War in 1941, the CPI utilized the lifting of the ban on their activities to make large organizational gains. They campaigned on issues of forced labour, illegal exactions and other levies that were further immiserating the already overburdened peasantry. Most of these actions were peaceful. Indeed, paradoxically, it was members of the Congress Party who initiated a violent struggle against the Nizam. The CPI joined the armed struggle at this moment, switching more decisively to 'violent' tactics in which they led raids on police stations, and the bungalows of the rich and higher officials, and burned records of land taxes. These actions allowed the movement to expand, and by mid-1946 it had begun to spread across numerous villages. The demands were still fairly 'moderate' at this point, including calling for an end to illegal exactions and landlord oppression. However, after the Central Committee of the CPI called for a general insurrection in September 1947, the Telengana revolt turned into a generalized rebellion against the Nizam. The background to this decision was the remarkable shift in the CPI's line from support to the new Nehru government in which it declared its intention to stand 'shoulder to shoulder with the national movement for full independence', ${ }^{22}$ to the position that the conditions were ripe for an insurrection across India ('this independence is a fake independence'). The rising Telengana revolt undoubtedly played into this decision, but so did the Communist International (Comintern) line, which had declared the importance of revolution in the colonies. This new international line also appears to have caused a shift in the balance of power within the CPI, with the more moderate communist leader P.C. Joshi sidelined by B.T. Ranadive, the architect of the new tactical assault on the Indian state. The Ranadive line called for a Chinese-style guerilla war, which was adopted by CPI units across India (indeed, in 1948 communist parties across other parts of Asia, namely, in Burma, Malaya and Indonesia, adopted the same insurrectionary line, only to be crushed). In Kerala, as we have seen, this tactical line led to violent confrontations in the industrial zones of Alleppey and Shertallai in the Travancore region, and the CPI was consequently banned in Travancore.

By 1948 in Telengana, 2,000 people were organized into 100 armed guerilla squads. In the large peasant insurrection that followed between 1948 and 1951, peasant squads created 'liberation zones' and conducted a massive campaign of 
attacking landlords, seizing land and grain in village after village. The revolt was no less than a massive challenge to the authorities, showing the formidable potential of a militant, organized peasant and working class alliance. What concerns us here is that the eventual trajectory of communism in Andhra was markedly different from the parliamentary communism of Kerala and Bengal crushed in one and institutionally absorbed in the others. These divergent trajectories bring us to the question of the historical moment at which left practices are generated, which can determine what their specific consequences are upon the 'basic social relations'. In Kerala, despite the large-scale arrests of communists and the general repression that followed, the party had embedded itself sufficiently during the 1930s to survive more or less intact. In Andhra, the same strategy and tactics destroyed the party. Brutal repression by the state resulted in nearly 80 per cent of the CPI cadres being killed or imprisoned. Roosa shows that leaders who doggedly implemented the Ranadive line, that is, ignored all indications that peasant squads were trapped in the forests, isolated from outside assistance, yet encouraged them to carry on fighting, essentially neglected a crucial dimension of the 'objective factors' obtaining in India - namely, a massive army and police apparatus, a new regime hostile to communist incursion and nervous enough to act on its unease. The Andhra case brings into sharp relief the point that despite 'favourable' structural conditions for a 'passive revolution', political practices deployed were at odds with what the political opportunities allowed - both before and after independence from the British. Because communists in Kerala availed themselves of key political opportunities within the nationalist movement in the region during the 1930s and 1940s, they were able to make use of parliamentary institutions towards comparatively radical policy ends. In Bengal, as we will see in the next chapter, a different time frame for communist-led mass radicalism and insurgency meant the weak political hegemony of the communists (comparatively speaking), and electoral dominance at the cost of a more broadly mobilizational strategy which the nationalist movement in Kerala afforded the Congress Socialists, and then the communists. 


\section{Structure, practices and weak left hegemony in Bengal, 1925-47}

By the time the CPI had won a strong political base and hegemonic influence in Kerala around 1940, in Bengal the CPI was a small, illegal party, with a somewhat restricted base among workers and tenants in parts of undivided Bengal. Kerala's trajectory, as delineated in Chapter 4, can be used as a 'benchmark' to understand the specificities of communist party formation in Bengal. The question is, to what extent did the political strategies and practices of the CPI, applied in the context of the specific 'objective conditions', colonial rule and the anti-colonial nationalist movement, matter in determining its narrow political base and organizational weakness in Bengal comparatively speaking? In the previous chapter I argued that the Kerala CSP's political practices of redefining lower caste politics in terms of the political-economy of class, and of working within and rebuilding the Congress Party, allowed it to build a mass base and attain a degree of political hegemony by 1940. These strategies and tactics were carried out in the nationalist political sphere where the dominant classes had failed to organize themselves as a strong opposition to the CSP. Did the differences in strategies and tactics between communists in Kerala and Bengal determine all of the disparity between the two parties, or were there 'objective factors' that made communist party formation in Bengal different to begin with? This question will eventually address the larger question of what effects the kind of base the CPI built during the nationalist period, and its specific (and shifting) strategies and tactics, had on its mode of ascendancy in the postindependence period, and what it could then do once it won state power in the post-independence era.

It has been argued that the 'sectarian' and 'isolationist' stance of the CPI, that is, its policy of isolating the party's activities from the mainstream (Congressled) nationalist movement prevented the communists from building their party until the mid-1930s. The 'failure' of the CPI in gaining political hegemony within the Indian nationalist movement has been pointed out by scholars such as Vanaik (1989), Sarkar (1983), Chandra (1986) and Joshi (1992). Vanaik, for instance, makes the familiar argument that: 
Communists of the National Movement period never grasped the relative strength and autonomy of the Indian bourgeoisie and hence its fundamental conflicts of interest with British metropolitan capital. Nor did they ever properly understand the nature of the Congress as both party and movement, or Gandhi's strategy of periodic and escalating compromise as a route to independence ... More accurately, the Communists failed to be both anti-capitalist and anti-imperialist in a consistent, principled manner while retaining tactical flexibility. Their oscillating and confused orientation to the Congress meant that Communists either opposed it from outside as a tool of a weak bourgeoisie subordinate to British capital and the colonial state or gave it uncritical support. (Vanaik 1989: 177, my emphasis)

Joshi (1992: 33) similarly asserts that the 'attitude of the Communists during the self-acknowledged phases of 'sectarianism' between 1929 and 1934 ... resulted in the absence among a substantial section of radical forces of any awareness of the role of the "other side" which prevented them from being fully aware of their own role either.'

A closer look at Kerala opens up a crucial line of enquiry, namely, might the communists have gained earlier ascendancy in Bengal had they adopted a more participatory approach to the mainstream nationalist movement, that is, worked within the Congress Party to 'transform it from within'? Or, put differently, was the Kerala CSP's strategy available to the Bengal CPI? This chapter will highlight, once again through comparison, how the 'objective conditions', namely, the presence of the politically assertive rich farmers (known as jotedars), and the presence of a well-organized anti-Gandhian faction within the Congress Party buttressed and supported by the landholding groups, made communist entry into and political ascendancy within the Congress Party a difficult option. Religious conflict between Hindus and Muslims, and the Partition of 1947, further affected the fortunes of communist organizers, despite the high potential for class-based radicalism. Most importantly, aside from these adverse structural circumstances, was the absence of the kind of structural and political shift taking place in Kerala (most importantly the dismantling of caste barriers) - thus the chances that communists' practices would enable their own ascendancy at this point of time were much weaker. These factors limited the base the CPI could develop within the period from 1934 to 1940, and indeed afterwards, well into the 1960 s.

\section{'Isolationism' and the early years of the Bengal CPI, 1925-29}

The CPI in Bengal, as in the rest of India, was formed in 1925, almost a decade before the CSP was formed in Kerala and elsewhere (1934). The Bengali communist M.N. Roy, who had developed his political affiliation in Mexico during the 1920s, brought together scattered groups of communists in India into the CPI, and linked it to the Communist International. The early leadership of the 
CPI in Bengal (contrary to the one that developed later) was almost entirely Muslim. The prominent CPI leaders at the time, Muzaffar Ahmed, Abdur Rezzak Khan and Abdul Halim, had come in contact with communism through guerillas who participated in the Khilafat agitation (which followed the disbandment of the office of the caliphate in Turkey after its defeat in the First World War) (Franda 1971). Between its formation in 1925 and 1935, when the CPI adopted a United Front line, the party shifted its strategies several times in accordance with directions from the Comintern.

While the CPI is viewed as having isolated itself from the nationalist movement between 1925 and 1935, this characterization needs some qualification. Until 1927 the CPI maintained an ambivalent attitude towards the Congress Party, opposing Gandhi's tactics of non-violence, yet seeking to work within the Indian National Congress (Overstreet and Windmiller 1959). Three members of the CPI's Central Committee constituted in 1925 were also members of the All India Congress Committee (AICC). Among the thirty-one accused in the Meerut Conspiracy Case in 1929 (see p. 164, note 1), five were members of the CPI and AICC (Ahmad 1959: 41). Indeed, as Ahmad, an early founder of the $\mathrm{CPI}$, points out, it was the communists who fought 'again and again' within the Congress Party for a resolution calling for complete independence from the British. In 1927, the attack on the Chinese communists by the Kuomintang opened up a debate first in the Comintern, and then among the Indian communists, over what the CPI's relationship to the Congress Party should be. The Comintern advocated a position of total isolation of the CPI from the mainstream nationalist movement in 1929, and until 1935 the CPI maintained this position. Between 1929 and 1935 the CPI branded the Indian National Congress a 'reactionary organization and an ally of British imperialism' (Democratic Research Service 1957 ('Draft Platform Action' in 1930): 3). The 'greatest threat to the victory of the Indian revolution', they argued, is 'the fact that great masses of people harbor illusions about the National Congress and have not realized that it represents a class organization of the capitalists working against the fundamental interests of the toiling mass [sic] of our country' (ibid.: 3). Furthermore, they argued,

[the] sole and historically tested means of winning independence, carrying out the agrarian revolution and achieving democratic reconstruction, is the path of the revolutionary struggle of the widest possible mass of the people, developing on to a general national armed insurrection against the British exploiters and all their allies in our country.

(ibid.: 7)

In Bengal during the 1920s, the CPI was almost exclusively involved in organizing workers, with no clear rural strategy, despite the name of its ostensible front - the Workers' and Peasants' Party (WPP). Through its organizing efforts, by 1927 the Bengal Jute Workers' Association had affiliated itself to the WPP, the 
Dhakeswari Cotton Mill Workers' Union was reorganized in Dacca, east Bengal, and the Scavengers' Union of Bengal was formed. The WPP/CPI was the dominant influence in the Calcutta industrial belt (Sarkar 1987: 72). The communists' focus on industrial organizing was an effort to bolster the size of the Bengal unit of the CPI, and motivated by the relative ease of organizing among workers concentrated in the Calcutta area. Even as late as 1934 membership of the Bengal CPI stood at thirty-seven (Franda 1971: 29). But its focus on workers was also a result of the fact that the CPI envisioned a proletarian leadership of the nationalist movement (see Karnik 1957: 3-22). The organizing efforts of the CPI continued until 1929 when the British government, in response to the upswing in labour radicalism across India, and the growing 'threat of Bolshevism', brought conspiracy charges on a number of important communist leaders and brought the CPI's activities to a temporary standstill. ${ }^{1}$ Indeed, the primary disadvantage the CPI faced was its particular relationship to the British colonial state, which considered the Congress Party to be the only legitimate representative of the anticolonialist position. British officials grew increasingly alarmed at what they viewed as the dangerous threat posed by the communists and used every means to suppress the CPI. The administration's Home Political files are replete with communiqués regarding the spread of Bolshevism within India, and the necessity for the administration to proscribe subversive literature and actively monitor the activities of the communists. For almost two decades after its formation, the CPI was forced to operate as an underground party (it was formally declared illegal by the British government in 1934).

The evidence certainly suggests that the CPI's policy of separation from the mainstream nationalist movement, its urban and worker-centred strategy, and most importantly state repression directly minimized the possibility of it forming a larger base in Bengal during the 1920s. In contrast, in that decade, the Congress Party in Bengal successfully organized peasants in no-tax movements in the districts of Midnapore, Kishoreganj and Arambagh in the western regions of Bengal (Bose 1986; Sarkar 1983; Chatterjee 1984; Sanyal 1979), thus consolidating itself in rural areas. Yet the restricted organizational capacity of the CPI would have precluded an extensive foray into rural organizing, particularly one that could compete with the Congress' leading of causes such as the no-tax movements. Instead, focusing its energy on organizing workers in the jute and cotton mills appeared to be the most fruitful; in 1927 and 1928 the WPP/CPI led a record number of strikes, and controlled twenty-eight unions, mostly in the Calcutta area (Sarkar 1987: 70).

The CPI's decision to withdraw completely from the nationalist movement in 1929 fell, as Sarkar (ibid.: 73) notes, on 'fertile and prepared soil', because of the Bengal communists' growing disillusionment with the leadership of the Congress Party, and the clear exhaustion of 'terrorism' as a political alternative. As I will discuss later in this chapter, despite their avowed anti-Gandhian leanings, the Bengal Congress Party leadership during the 1920s (the Swarajists), represented and actively defended the interests of the leading industrial and large landowners. 
Moreover, huge numbers of ex-'terrorists' began to join the CPI during the early to mid-1930s, as they came to realize the futility of their tactics, and confronted the real threat of state violence. The consequent rise in membership gave the CPI the sense that it could carry out a strategy independent of working within the Congress Party, despite the fact that it had been declared illegal by the British and was forced to work underground.

The period between 1927 and 1929, however, was a potential branching off point for the communists. The Executive Committee Report of the national WPP in 1927-28 instructed the communists to work as much as possible with other nationalist organizations. It stated that 'The WPP ought to be careful not to oppose the Congress except on well-defined, individual issues, otherwise we shall enable our opponents to claim that we are anti-Congress or even antinational and that we stand merely for the sectional claims of labour' (Sarkar 1987: 74). Indeed, before the CPI turned away from the Congress Party in 1929, in Bengal, three members of the WPP were elected on to the Bengal Pradesh Congress Committee (BPCC) in 1927, and two of them became members of the AICC (ibid.: 72). Yet the communists in Bengal also chose at this juncture to oppose and distance themselves completely from what they saw as 'an institution for the higher classes' (ibid.). It becomes possible, then, to ask what might have happened had the communists in Bengal chosen to participate within the mainstream nationalist movement? The option of working openly as a faction within the Congress Party, which was open to the Congress Socialists in Kerala, was not an option for the communists in Bengal. This factor precluded the possibility that the communists could grow as a separate party within the Congress Party - at least this option was made far more difficult. But a different relationship between the Congress Party and the CPI in Bengal was a possibility, one that involved participation in the Bengal Congress' 'mass' campaigns such as the civil disobedience movement of the early 1930s. Could the communists have benefited from such a relationship, that is, could they have had a greater chance of building up their party and gaining political ascendancy?

\section{Nationalism, caste and class: the Congress Party in Bengal, 1920-40}

The 'objective conditions' that confronted the communists in Bengal, then, were on the one hand a strong potential for class-based radicalism among sharecroppers and workers, on the other the potential obstruction of class-based organization by the jotedars who were also the backbone of support for the Congress Party in Bengal. This latter factor strongly affected the extent to which an already small and organizationally weak CPI could participate in rural politics within or outside the mainstream nationalist arena during the 1920s.

The jotedars were a class of 'rich peasants' who struggled fiercely against the larger landlords for occupancy rights in the jute growing areas during 1873 (known as the Pabna Revolts). Throughout the late nineteenth and early twentieth 
centuries, the jotedars were key political actors, engaging simultaneously in antilandlord struggles, struggles against the colonial state, and yet exercising a restraining influence upon the radicalism of poor tenants and landless labourers (Chatterjee 1984; Bose 1986). Often jotedars were drawn from the same caste as the sharecroppers and poor tenants below them, and they used caste allegiances to unite both classes in agitations against the British. Thus, in East Midnapore, West Bengal, during 1920-21 jotedars led a strong movement against the British who had imposed Union Boards in place of the traditional self-government panchayats in the villages. In addition, the British raised existing village watch taxes (chowkidari) by 50 per cent (Sanyal 1979: 169). This movement united the sharecroppers who worked the lands of the jotedars temporarily under the Congress Party, which led the movement. Although the jotedars owned between 100 and 3,000 acres of land cultivated by the sharecroppers (who took half the produce and were assessed for all sorts of illegal levies), they could use their common caste status as Mahisyas to unite with their tenants under the Congress Party. Indeed, the jotedars and some zamindars led a movement for upward mobility among the Mahisyas during the late nineteenth century, and in this fashion exercised traditional leadership upon the poorer Mahisyas.

The sharp class dichotomy within the Mahisya caste stands in contrast to the caste-class hierarchy found in Kerala. This comparison brings out the importance of caste-class homogeneity in Kerala (and indeed other regions where caste and class were more or less homogeneous as in Maharashtra, Mysore or Tamil Nadu), wherein lower caste movements could potentially be politicized as a question of class formation. Of course, it must be emphasized that caste was not an insurmountable barrier to class conflict in Bengal either. In the same region of East Midnapore, sharecroppers began to turn against jotedars and zamindars in course of the 1930-31 civil disobedience movement (Sanyal 1979: 176, Bose 1986: 240). In the Contai and Tamluk districts of Midnapore, bhagchasis or sharecroppers even resorted to armed clashes against the jotedars (Sanyal 1979: 176). The Congress Party intervened and attempted to negotiate between the two sides in a tactical move to save the anti-Union Board movement. Its efforts resulted in a settlement, which did not concede all the demands of the sharecroppers, and in a sense, dampened the radical potential of their actions. ${ }^{2}$

It is instructive at this point to compare the conditions that the CSP in Kerala faced at the onset of their ascendancy, with those the CPI in Bengal faced. The first was the presence of the politically active jotedars and zamindars in Bengal. The corresponding class of landowners in Malabar, that is, the jenmis and kanomdars became politically active and represented themselves as a class, defending particular class interests within the larger ambit of nationalist politics (i.e. in the Congress Party). But by the early 1930s neither the Malabar Kudiyan Sangham (the organization of the predominantly Nair kanomdars), nor the Jenmi Sabha and various jenmi organizations were active in the Congress Party. The jenmis, having been defeated by the kanomdar motion in the early 1920s, left the Congress Party in Malabar. Likewise, the kanomdars withdrew from the 
Congress Party after winning the Malabar Tenancy Act of 1930. The MTA itself was granted to the kanomdars after a long period of struggle in which they organized themselves through the KPCC during the 1920s. The provisions of the act were far-reaching, granting them permanent occupancy rights, forbidding their eviction by jenmis and, in effect, making them the 'new landlords' vis-à-vis the tenants-at-will or verumpattomdars. In Kerala, neither class (jenmis or kanomdars) held an enduring interest in nationalist politics, and thus over time the 'right' within the KPCC came to constitute an ideological, but not class opposition to the CSP in Kerala.

In Bengal, however, the jotedars continued to play an important role in the Congress Party through the 1920s and early 1930s, although their support for the party was not uniform across regions. The struggles launched by the jotedars during the late nineteenth century had forced the colonial state to undertake tenancy legislation in the form of the Bengal Tenancy Act of 1885 that restricted the grounds on which the landlords could claim increased dues from occupancy tenants. However, the landlords who were sufficiently well organized through the British Indian Association, lobbied successfully for the withdrawal of the right of free sale occupancy rights (Ray 1984: 234). The jotedars continued to press for firmer tenurial rights, which they finally won in 1928 (under the Bengal Tenancy Amendment Act) in the form of full rights to transfer land. There were no provisions for sharecroppers in the amendment, and no lobby to press for their rights.

In the eastern districts of Bengal, the predominantly Muslim jotedars were actively opposed to the Congress Party because it was identified as a party of the landlords, to whom 'tenant-right was landlord-wrong' (Gallagher 1973: 599; see also Chatterjee 1984: 85 on Congress vacillation on anti-landlord measures). Here, jotedars or occupancy tenants (variously known as occupancy raiyats) had launched anti-landlord movements in various districts through the 1920s (in Tippera in 1923, Mymensingh and Dacca in 1924, Tippera, Mymensingh, Pabna and Jessore in 1926) (Gallagher 1973: 599). Moreover, this split between landlords and tenants was also articulated in religious form - since most landlords were Hindus, and the tenants were largely Muslims. The mainly Hindu leadership of the Congress was therefore viewed with suspicion, and as a result the Congress Party began to lose mass support in the eastern districts of Bengal by the early 1930s (ibid.: 608). The civil disobedience movements launched in 1930-31 not only drew little support, but actually provoked opposition. In Dacca, Faridpur, Bakarganj and Mymensingh, Muslims and low caste Namasudras asserted themselves against the Congress-led campaigns (ibid.: 609). The growth of Hindu-Muslim conflict was rapid during this period, particularly after the death of the Congress leader C.R. Das, who had worked out a Hindu-Muslim pact by tying the Khilafat and non-cooperation movements together (Chatterjee 1984: 65). But in eastern Bengal, the persistent outbreak of communal, that is, Hindu-Muslim conflict, lessened the chances of the CPI creating a significant 
base among the Muslim peasantry, despite their common opposition to the Congress Party.

In contrast to jotedar opposition to the Congress Party in eastern Bengal, in the western and south-western regions of Bengal, the jotedars exercised their growing dominance in rural politics in the form of leadership of anti-colonial protests (such as the anti-chowkidari tax revolt discussed earlier). These protests continued until 1933, for example against a new revenue settlement imposed by the British administration upon the district of Arambagh in western Bengal. But apart from in Arambagh and the old stronghold of Midnapore, the civil disobedience movements lacked mass support, and this, together with the Congress fiasco in east Bengal, marked the slipping of the party's control over the region's politics. Nevertheless, the basis of Congress support in Bengal lay, as it did across India, among the 'dominant peasants'. Most of these peasants, as research from other regions has traced, were upwardly mobile, linked increasingly to a cash economy, and had newly acquired access to a western education. Examples of such peasants are the Patidars in Gujarat, Kurmis and Ahirs in the eastern United Provinces and Jats in the western United Provinces, who looked to the Congress Party as a means of fulfilling their political aspirations (Low 1977: 23). The jotedars in the western and southwestern regions of Bengal were such a group, whose leader Birendranath Sasmal (in Midnapore) sought links with the Congress Party during the 1920s (ibid.: 22).

The contrast between the jotedars in Bengal and the kanomdars in Kerala shows that the difference lay in the degree to which each class exercised a political role within the Congress Party and in nationalist politics. Although both classes had won crucial tenancy reforms, the kanomdars were unwilling to take on a further political role whereas the jotedars were. The reasons for this are not clear, and further research is necessary to locate the source of the differences in their political behaviour. The 'dominant peasant' thesis, as put forward by Low (1977), Hardiman (1989) and others, is somewhat vague because it does not differentiate between the structural locations and political behaviour of these 'dominant peasants'. One crucial distinction between them appears to be that the jotedars were identifiably village leaders, with the social authority of village heads and the position of creditors and employers, who could use their authority to mobilize the peasants against increases in revenue and village taxes. Alliances between jotedars and the superior tenants of the estates kept other possible tensions with small peasants and sharecroppers in check, which helped in maintaining 'a remarkable quietude in the countryside during the first half of the nineteenth century' (Ray 1984: 232). While tensions between the jotedars and zamindars were rather few between 1800 and 1858, in the second half of the nineteenth century jotedars began to band together in well-organized agrarian leagues to fight the enhancement of rates and illegal cesses by the zamindars. This organizational unity was later turned against the colonial state, as in the notax movements led by Congress (and backed by jotedars) in Bengal during the 1920s. In Malabar, it was the Muslim kanomdars in southern regions who put up 
the fiercest resistance to Hindu landlords (the Moplah Revolts). The more organized kanomdar lobby, however, was stronger in north Malabar, principally among the Nairs. Most of them were primarily concerned with reinstating the traditional tenancy rights that had been lost with the implementation of colonial policies. Their interest in the Congress Party was largely expedient, and concerned with moderate methods of petitioning for tenancy reforms rather than with organized resistance to the jenmis. Perhaps the greatest difference between the case of Bengal and Malabar lies in the absence of a no-tax movement in Malabar, which in Bengal and other regions was generally carried out by the Congress Party through the leadership of the 'dominant peasants'. More research on this point is clearly needed, but it appears that the difference between the jotedars and the kanomdars was significant, and impacted their political roles in the nationalist movement.

The special opening available to the CSP because of Congress involvement in lower caste movements in Kerala was also not present in Bengal. The caste system in Bengal, in contrast with that in Kerala, was less hierarchical. Brahminical Hinduism was less entrenched in Bengal than in Kerala or other parts of India, and Bengali Brahmins interdined with low castes and ate meat and fish (Kohli 1989: 395). Neither were the rules of untouchability as strictly enforced on such a large portion of the population as in Kerala, and 'unseeability', that is, the prohibition of lower castes to even be seen by upper castes, did not exist. Not only was the caste system less hierarchical, but it did not correspond as neatly with rural relations of domination and surplus extraction as found in Kerala before the full impact of British policies took effect. There were large differences in property rights and control over land within castes, such that whatever proclivity there might have been towards lower caste movements in Bengal did not have much potential to turn in the direction of militant, radical class-based movements.

Although the Bengali caste structure was comparatively less hierarchical than the caste structure in Kerala, British rule did not create comparable opportunities for the lower castes that allowed them to gain economic mobility, as in Kerala. The higher (Brahmin, Kayastha and Baidya) and middle (Nabasakh, Namasudra, Mahishya, Kaibartta) ranking castes continued to be largely the rent-receiving groups, and the lower stratum of sharecroppers and landless labourers were drawn from the 'unclean' and 'untouchable' castes (Sahas, Jogis). With the growth of trading companies, white collar and industrial employment, it was the largely upper and middle ranking castes that took advantage of the new opportunities (Bandyopadhyaya 1990: 142). The castes corresponding to the Ezhavas and Tiyyas, who bore the worst of the effects of untouchability, did not enter these professions. This factor may explain the absence of a strong push to reform, and eventually abolish, the caste system, which the growing middle class among the Ezhavas and Tiyyas were able to provide in Kerala. Instead, the caste associations that began to develop in Bengal in reaction to being classed as 'depressed' in the census of 1901, sought to gain a protective status from the 
British. This effort followed the establishment of 'protective discrimination' that the British granted to the Muslims (ibid.: 144). Indeed, a strong part of the push among the lower castes towards self-organization was propelled by their perception of gains made by Muslims; this was a factor that allowed Hindu chauvinist organizations such as the Hindu Mahasabha to win some degree of ideological hegemony over the Muslims' organizations.

The lower caste Namasudras and Mahisyas viewed the Bengal Congress as a largely bhadralok or upper caste organization, and thus stayed away from the mainstream nationalist movement. Their perception was entirely accurate. In 1924-25, 69.4 per cent of the members of the Bengal Pradesh Congress Committee belonged to the upper castes or bhadralok (Gordon 1974: 196). The bhadralok were explicitly concerned with the threat posed by the low caste movements to their dominant status (Broomfield 1968: 124). The Namasudras and Mahisyas actively boycotted the swadeshi (campaign of boycotting Britishmade goods), non-cooperation and civil disobedience movements, and professed their loyalty to the British (the newspaper Tilir Gaurab, carried on the front page of every issue an appeal 'with folded hands and devoted mind' for the permanence of British rule in India) (ibid.: 153). The loyalism and distancing from the mainstream nationalist movement was, however, not exceptional to the low/middle caste movements in Bengal, and was shared by lower caste associations in Kerala as well. The difference between the lower caste movements in Kerala and Bengal was simply one of scale - in Bengal they did not reach the scale that, for example, the Ezhava movement did, and in the absence of interest from Congress leaders, did not have the political impact that the caste movement did in Kerala.

There was another crucial difference between the two cases, namely, the varied caste backgrounds of jotedars. In Bengal, although zamindars were drawn primarily from the Brahmin or upper caste Kayasthas, jotedars came from a variety of castes that included both upper castes as well as the lower Sadgops, Namasudras and Aguris (ibid.: 398). Indeed, jotedars were often drawn from the same caste as the poorer tenants or sharecroppers - a factor that made the polarization of caste and class together more difficult. Instead, jotedars could use their caste status to mitigate intra-caste conflict and unite with poor tenants and sharecroppers in anti-colonial protests. The only notable exception appears to have been the Mahisya caste, who despite their professed loyalty to the British participated in the anti-Union Board movement in Midnapore during 1919-20. This movement, as discussed earlier, was led by the jotedars, who used their caste identity to draw the sharecroppers into a temporary alliance against the British. The limited co-mingling of mainstream nationalism with a lower caste movement can, then, more accurately be described as an alliance between an aspiring class of rich tenants and the Congress Party. This stands in sharp contrast to the involvement of the Congress Party in Kerala in the lower caste movements for the abolition of untouchability and the bar on temple entry. ${ }^{3}$ 


\section{'Right' vs 'Left' in the Congress Party in Bengal, 1920-40}

Could the CPI (as did the CSP in Kerala during this period from 1934 to 1940) have built a mass base among smallholders, sharecroppers, landless labourers and workers, while also gaining hegemony within the nationalist field in Bengal during the 1920s? The answer is that because of its small membership, organizational weakness and the absence of crucial openings in the nationalist movement, such a probability was extremely weak. But I also hypothesize, on the basis of the comparative case of Kerala, that the class composition and political and organizational strength of the political forces within the Bengal Congress Party (i.e. the BPCC), would have made the process of winning political hegemony exceedingly difficult for the CPI.

In the previous chapter I argued that the CSP in Kerala could easily rival the 'right' Congress because it represented the class-based organization of peasants and workers in the three regions, while its opponents merely formed an ideological opposition. In addition, the CSP could take advantage of the opening provided by the lack of a formal Congress organization in the two princely states of Travancore and Cochin. It was thus able to capture the nationalist position occupied in most parts of British India by the 'right' Gandhian Congress. This evidence supports the general hypothesis that the political ascendancy of left parties within an ongoing national conflict depends, in part, on the degree to which they can represent themselves as nationalists, as did the CCP in China, the Vietnamese communists, among others (Johnson 1962; Kolko 1985). The communists in Bengal confronted potentially greater resistance to their ascendancy within the nationalist political field in which the anti-Gandhian position was occupied by the upper caste bhadralok and landowning classes during the 1920s, compared with the Congress Socialists in Kerala, who occupied both the anti-Gandhian and nationalist position.

A crucial difference between Kerala and Bengal during the 1920s and 1930s was the presence of a distinctly urban class of big rentiers in Bengal, also known as the bhadralok (literally meaning 'big people' or gentlemen). A product of colonial rule in Bengal, the largely Calcutta-based bhadralok had grown on the basis of investment in urban and rural ground rent, which during the late nineteenth century represented secure and profitable means of investment (McGuire 1983: 16). For example, in the years following the Permanent Settlement, from 1806 to 1857 , prices of holdings in rural Bengal rose by 500 per cent (ibid.: 14). This was a direct consequence of the break in the monopoly of the East India Company, and the rise in trade that accompanied it (which in turn generated a growth in petty commodity production). The rise in trade also led to a rise in urban real estate, particularly in Calcutta, as more and more trading houses sought investment in Bengal. The bhadralok were organized into the British Indian Association (in 1885, 91 per cent of the key organizational positions were filled by the rentier aristocracy) (ibid.: 85). Since many of them were also zamindars, members of the association actively opposed the interests 
of the peasants on the grounds that any measures that benefited them were opposed to the spirit of the Permanent Settlement.

Internal class divisions among the bhadralok are key to understanding shifts in its political behaviour as a class. Parallel to the rise of the rentier class was a 'middle' class that was mostly employed as commercial traders, small brokers, shopkeepers and in the British bureaucracies and agencies, which helped the colonial state to penetrate Bengal and extract revenues (ibid.: 18). Yet they were not allowed (in practice, if not in theory) to enter the Civil Service - in 1885 only six of the 174 members of the Civil Service were bhadralok (ibid.: 19). They tended to be more consistently nationalistic than the former group of bhadralok, forming the Indian Association in direct response to what they perceived to be the political inadequacies of the British Indian Association. The Indian Association consisted of 38 per cent lawyers, 14 per cent landholders (small to medium), 14 per cent teachers, and the rest either editors, doctors or merchants (ibid.). The Indian Association consistently opposed the zamindars, but not in order to support the peasantry. Instead, they were largely concerned with gaining a share in cultivable land for profit.

Until the early 1920s, the Indian Association virtually controlled the Congress Party in Bengal. It nominated the majority of the candidates in the BPCC, and filled casual vacancies (Broomfield 1968: 137). However, they were largely aligned with the 'Moderates' - the section of Indian nationalist opinion, that preferred gradual reforms and entry into British councils. In the early 1920s, after the failure of the non-cooperation movement in Bengal, a young Congressman, C.R. Das, took control of the BPCC. Das came from a family of lawyers in eastern Bengal, and won fame during the political trials of leading Bengali nationalists such as Aurobindo Ghose and Bipin Chandra Pal during 1907-08. He represented the 'Extremists' who firmly opposed council entry, and held that the pressure exerted on the British by the Moderates was not sufficient. Das also drew into the BPCC a section of the 'terrorists' who had been involved in a series of violent attempts to overthrow the British during the late nineteenth and early twentieth centuries. Das also had national-level ambitions, and sought to influence all-India Congress policy simultaneously. With the arrest of most of the Congress leaders, including Gandhi, in 1920-21, the leadership was vacant. Das formed the Swaraj Party upon his release from prison in 1922, disillusioned with the lack of interest among Congress members in organizing workers. An intelligence report stated that '[c]ommunist links have certainly obtained a measure of recognition from a prominent Indian non-cooperating politician' (cited in Mitra 1981). Towards the end of 1923, Das also won the presidency to the BPCC, with the Swaraj Party gaining a majority within the BPCC (Broomfield 1968: 235). Das' politics appealed directly to the 'lower' bhadralok as against the methods of the Moderates because he launched a direct attack on the values of the 'babus' or bhadralok elite.

The attack on the anglicization and elitism of the 'upper' bhadralok gave an appearance of social radicalism that did not really hold true in content. The 
Swaraj Party and the 'lower' bhadralok were exceedingly cautious about involving the 'masses' in any form in nationalist politics. They ignored criticisms from lower caste associations who asserted that despite giving lip-service to social radicalism in reality the Swarajists were just another upper caste party (ibid.: 236). The Swaraj Party also consistently voted in favour of zamindars and landholders against peasants in the vote on the Bengal Tenancy Amendment Act of 1928. The voting bloc of the Swaraj Party consisted of successful Calcuttabased professionals, big landlords, district organization leaders (often with 'terrorist' connections) and various other landlords and businessmen (see Chatterjee 1984: 83-95). In this fashion, the 'Extremist' position came to occupy centre-stage in Bengali mainstream nationalist politics. But this 'left' faction in no sense resembled that which was assembled together in the case of Kerala, and may indeed, as Broomfield (1968: 161) argues, need to be characterized as the 'right'. Despite its anti-Gandhian leanings and links with revolutionary 'terrorists', the Das faction was by all accounts an elitist one. The opposition of the 'terrorists' to Gandhi came not so much from a strong orientation towards the masses, but from basic cultural differences between the doctrines of 'shaktism' (emphasizing violence and struggle), and Gandhi's favoured 'quietist' doctrines of Vaishnavism and Jainism (ibid.: 148). The emphasis on passive resistance to the British did not appeal to the bhadralok, who were far more dazzled by the revolutions in France and Mazzini in Italy. The two groups that dominated terrorist activity from the early twentieth century, Jugantar and Anushilan Samiti, engaged in daring raids on arms catchments and the bombing of colonial offices and officials. Both groups and the hundreds of scattered offshoots advocated revolution through armed struggle, and were organized through strict discipline in secret societies. The basic unit of organization was the 'dal', which consisted of a group of followers who owed complete loyalty and devotion to the leader. Often the 'cult of authority' was so critical that when a leader died the entire faction would disintegrate (Gordon 1974: 177). Although the terrorists were to become a source of embarrassment to Das, they constituted a prominent and potentially important alliance for him during his initial attempts to capture the leadership of the BPCC. In comparison with the Congress Socialists (and the Congress leaders that predated the party), however, the anti-Gandhian position of the Swaraj Party was not socially radical. It expressed little interest in issues of caste, untouchability or rural distress. Nevertheless, it constituted a wellorganized faction that, moreover, fully controlled the direction of the nationalist movement in Bengal during the 1930s. Could a left-leaning party such as the CPI have succeeded in capturing this ground from the Swarajists?

The evidence suggests that such a strategy might have been exceedingly difficult, for the communists would have had to contend not only with the political influence of the zamindars and jotedars, but also with the Swarajists, revolutionary terrorists (whose violent tactics were opposed to those of the communists) and other organized nationalist opinion. The comparison with the CSP in Kerala adds further evidence to the hypothesis that the communists in 
Bengal would have faced a more difficult political terrain within which to gain political ascendancy. The choice on the part of the CPI to work outside the Congress Party, then, was not simply a strategic error, as Chandra (1986) (1992) and others suggest. Instead, in the specific conditions of colonial Bengal, the communists were placed in a more disadvantageous position by a potentially far more formidable and organized opposition than were their counterparts in Kerala. This feature of the 'political field' in both instances in turn derived from two features of British colonial rule: (1) the different sets of objective conditions and caste-class relations; and (2) the greater importance of Bengal to the British administration, and hence its centrality in the anti-colonial struggle. Unlike in Kerala, then, the nationalist position in Bengal was more likely to be prominent, because the BPCC was a critical part of the nationalist struggle and the All India Congress Committee. This may be one reason why a social reform agenda could not surpass the objective of ousting the British at any moment during the movement.

In the period following Das' death, there was some radicalization of the Congress leadership in the form of Subhash Chandra Bose, who had 'socialist' sympathies and close ties with revolutionary 'terrorists' in Bengal. Under his leadership, for example, the 1929 provincial conference of the BPCC called for closer ties between the Congress Party and peasants' and labour organizations (Gordon 1974: 245). But in 1928 Bose had actively supported the anti-peasant Bengal Tenancy Amendment Act, and some of his support was drawn from the 'Big Five', a group of prominent businessmen and zamindars (Chakrabarty 1990: 29, also see p. 67). This paradoxical relationship between professed political sympathies and practice did not allow the Congress Party under Bose to make any significant inroads into rural areas.

\section{Communists 'enter' the national movement, 1935-41}

In 1937 the Bengali newspaper the Statesman remarked that: 'the masses waited, unorganized, outside party politics' (Gordon 1974: 298). Indeed, the Congress Party's internal evaluation in 1936 revealed not only how few of its members were 'peasants' or workers, but also how few peasant organizations actually existed in the districts. The percentage of peasants or workers in the District Congress Committees ranged between 5 and 10 per cent, with a few exceptions, and the percentage of workers was often reported as 'negligible' or 'nil' (see Gallagher 1973: 637). The exceptions were Jalpaiguri in North Bengal, Howrah, Nadia and Hooghly. However, even in these regions, with the exception of Jalpaiguri, as the discussion until now has shown, the category of 'peasants' in all likelihood mostly included landholders and small peasants rather than sharecroppers and agricultural labourers. Apart from Burdwan, Dinajpur, Sylhet, Dacca and Noakhali, none of the districts had functioning peasant organizations. In addition, the Congress Party was considerably weakened by internal quarrels after the death of C.R. Das. 
The waning of Congress influence in Bengal provided, at least in theory, a crucial opportunity for a 'take-over' by the communists. In 1935 the National Executive of the CPI, under the leadership of P.C. Joshi, adopted the tactic of 'United Front', seeking an alliance with the CSP (the 'progressive' element within the Congress Party) 'from above', and the formation of mass organization of peasants and workers 'from below' that would collectively affiliate with the Congress Party (Overstreet and Windmiller 1959: 161-66). Until 1938, however, large numbers of 'terrorists' and communists were still in jail (as numerous 'terrorists' became communists in jail), detained under Regulation III of 1818, the Bengal Criminal Law Amendment Act of 1930 and the Bengal Suppression of Terrorist Outrages Act of 1932 (Chaudhuri 1979: 355). In prison, many Anushilan Samiti and Jugantar revolutionaries had become increasingly drawn to Marxism and communism. As one participant recalls, for them, the struggle, 'whether the non-violent struggle under the leadership of Gandhiji or the armed struggle of the revolutionaries, had reached a dead-end. Hence the search for a new path had become inevitable'. ${ }^{4}$ With the release from prison of communists in $1938,{ }^{5}$ the CPI's first efforts to mobilize and build a base in rural areas gained some impetus. Many cadres spread into rural areas and for the first time between 1937 and 1939 the CPI in Bengal began functioning as a 'full-fledged' party with units in all the districts of Bengal (De 1980: 269). Not surprisingly, however, the Bengal CPI ruled out any possibility of joining the Congress Party, arguing that although the influence of the Congress Party was waning, '[ $\mathrm{t}]$ he bourgeoisie will try its best not to lose its power by a change in the constitution and will manoeuvre its best to deceive the petty bourgeoisie again - the possibility of the communists being driven out is also not remote' (extract from Communist Review, October 1935, in Roy 1976: 65-66, my emphasis). The acuteness of the post-Depression agrarian crisis, they argued, meant that the political repercussions were

more sharply tuned than in the rest of India. Our joining the Congress in Bengal would, therefore, amount to reviving the bankrupt semi-feudal strongholds - an attempt to whip up the dead horse to life under a veritable martial law regime ... There being no other alternative than secret work in Bengal, it would be best to concentrate under the legal cover of the Congress upon the secret work of the Party.

(ibid.)

The contrast between the CSP (or CPI) in Kerala and the CPI in Bengal at this conjuncture is sharply evident. While the CSP was in the process of capturing control of the KPCC during the mid-1930s, the Bengal CPI still feared losing ground within the Congress Party - although in both instances the Congress Party was in an organizationally weak state during the early 1930s (in the aftermath of the second civil disobedience movement). Moreover, between 1935, when the CPI began to work within the Congress Party through the CSP, and 1941, when it agreed to adopt the People's War line and refrain from anti-British activities, it 
was also an illegal party. The historical advantage available to the CSP, as for example in Kerala, was therefore foreclosed to the CPI. Clearly, this factor had the most crucial effect on the degree to which each party could carry out its strategies and build a mass base. As Abani Lahiri, a communist member during that period recalls,

[t]he Party took a decision that we should all be in a state of semiunderground existence. Semi-underground meant that we should not stay at home at night nor go out into the streets during the day, have no personal contact with offices of mass organizations which were likely to be under police surveillance.

Although communists in Kerala were similarly compelled, this did not occur at a time when the party was laying down its roots. In Bengal, however, rural organizing suffered from the inability of the communists to stay in one place for too long for fear of being discovered. As Abani Lahiri describes it:

It was decided that I should go to Dinajpur, where the movement against the imposition of tolabati (a feudal exaction) on the village haat had spread widely, but had later collapsed under state repression. Sitting in Calcutta we couldn't appreciate the actual situation there. When I arrived there, I found no workers of ours except a few peasant activists. Our workers were either in jail or home-interned. Sushil Sen was at that time the secretary of the district committee of the Party. He too was home-interned. I came to realize after meeting him that all contacts amongst our workers had been snapped. Wherever I went in the area accompanied by a couple of peasant activists, I noticed a feeling of helplessness.

(ibid.: 35)

Those were strange times. Maybe I would be traveling in a bullock cart. I had no idea as to where I would go. My only possession, a small suitcase, lay hidden under the hay or the belongings of the escorting peasant ... At times I would feel that I wouldn't be able to achieve anything. A deep despair would take hold of me ... I used to feel deeply discouraged whenever I was warmly welcomed in a peasant home and shortly afterwards told that I would have to go to another place for shelter. It was a sign of the loss of morale.

(ibid.:38)

Despite this historical disadvantage, the CPI made some headway in organizing sharecroppers. The sharecropper revolts against jotedars in north Bengal in 1939-40 have been described earlier in this chapter. These and other campaigns were conducted by communists under the aegis of the Bengal Pradesh Kisan Sabha (BPKS), formed in 1936 (a branch of the All India Kisan Sabha). Unlike the All Malabar Peasants' Union which was directly under CSP control, 
the BPKS was at first led by CPI, CSP and radical Congress members. Gradually, however, by 1938 the CPI came to control the BPKS leadership positions. The membership of the BPKS rose from 34,000 in 1938 to 83,160 in 1943, doubling to 177,629 in 1944 (AIKS 1944). The BPKS undertook numerous anti-landlord campaigns during 1937-40 on behalf of sharecroppers. For example, during 1937-38 the BPKS led an agitation that involved demonstrations, meetings, forcible occupation of lands and removal of paddy in certain zamindari estates. In Midnapore, west Bengal, peasants demanded the abolition of illegal cesses on shares of crops, a reduction of rents and protested against a canal tax (Cooper 1988: 135-36). In northern Nymsensingh in north Bengal, the BPKS organized protests calling for raiyati rights and rent reduction. Because of the growing influence of the BPKS, and the pro-peasant orientation of the Congress ministry, these demands were conceded (Bhattacharyya 1978: 613). The efforts of the communists in organizing rural and urban workers (in jute and cotton factories, and in railways) during this period were, in fact, so assiduous that the colonial authorities in Bengal noted that ' $[\mathrm{t}]$ he influence of prominent communists is visible in practically every organization' (Chaudhuri 1979: 355). However, the campaigns that the CPI undertook were regionally confined to two districts in northern Bengal, and three districts in West Bengal. Moreover, the prior organizational weakness and limited size of the Bengal CPI itself further reduced its chances of gaining political hegemony. In 1942 the CPI in Bengal numbered roughly 1,000 members (Franda 1971: 29), compared to the Kerala CSP, which commanded a sizeable portion of the 50,000 Congress membership.

One explanation that is commonly evoked for the limited impact of the Bengal CPI during the nationalist period is the class origins of the communist organizers (that is, their bhadralok origins), which, it is argued, led to a highly 'elitist' style of politics. Chatterjee (1984: 177-79), for example, has argued that among the bhadralok who converted from 'terrorism' to Marxism during the 1930s, 'there was considerable skepticism, even contempt, about the political maturity of the masses and about the feasibility of effective political action on the basis of mass agitation'. Or, as Broomfield (1968: 321-22) puts it: 'it was a problem of thoroughly literate men trying to make themselves understood by the unlettered, of a written tradition confronting an oral tradition'.

The social distance between the bhadralok organizers and the low caste, often untouchable caste peasantry was undoubtedly large, and a potential barrier to organizing. However, there are two reasons why the class origins of the CPI organizers will not suffice as an explanation for the weakness of the party. First, comparative evidence from Kerala shows that the CSP organizers were invariably higher caste Nairs or Namboodiris, and the tenants or workers they were organizing, that is, lower caste Ezhavas, Tiyyas and other untouchable castes. As I argued in Chapter 4, the caste origins of the CSP posed potential problems in a context where the caste hierarchy was so rigid that eye contact with those from the lower castes was forbidden. In this context, distrust and suspicion of the upper castes was high, and caste barriers had to be literally broken down by the 
organizers who entered the houses of the tenants, sat on the floor and ate with them, accepting their food, and minimizing as far as possible the daily rituals of pollution and separation. However, what was crucial about the encounter between the upper and lower castes in this context was the fact that the caste barriers between them were already crumbling by the mid-1930s, in no small part because of the efforts of the younger generation of Nair and Namboodiri social reformers.

The breaking up of the landed aristocracy, and along with it the edifice of the caste system, had begun before communists became active in Kerala (although they decisively completed the process through their practices during the nationalist movement and in the post-independence period). This made their practices 'structurally relevant' in a way that the organizing tactics of the communist leadership in Bengal could not have been. In other words, the political practices of Kerala's communists, derived from the 'great transformation' of its agrarian caste hierarchy, embedded the party in the very process. The colonialnationalist context of Bengal, on the other hand, made for a vastly different context. There is sufficient evidence to show that many activists and organizers in Bengal during the mid-1930s attempted to break down the distance between them and the poorer peasants that they were organizing. In 1937 communists working under the cover of the Congress Party held small meetings (baithaks) and larger meetings with peasants in the market-places. One organizer admitted that, 'We had to fight their distrust of town people, and gain their confidence and be one of them. We stayed with them, took their food, and slowly their distrust diminished' (quoted in Cooper 1988: 132). For high caste organizers to accept food from the low caste and marginal Hindu peasants was highly significant - as peasants active during the communist-led campaigns recalled, 'the communists had no contempt for us; they would eat with us' (quoted in Bhattacharyya 1978: 624). Communist cadres attempted to make themselves 'déclassé' by wearing the peasants' traditional dress, adopting their ways of living and speaking, and by renouncing their own families (Cooper 1988: 132). In addition, many of the CPI and CSP organizers used popular idiom to convey their political message, rather than relying upon modern or secular ideas. ${ }^{6}$ They used stories from the Hindu scriptures, the Ramayana, Mahabharata and Puranas, and where there were predominantly Muslim peasants they made use of Islamic injunctions against usury and discrimination on the basis of wealth, and nurtured the spirit of jihad (holy war) against oppression (Das Gupta 1992: 176). Gradually, the 'naya swadeshi babus' (new Indian gentlemen) as they were known initially, came to be addressed as 'comrades' by the lower castes (ibid.). Such instances point towards a considerable shift away from the earlier style of the bhadralok, whose political stance had been one of conscious and wilful distancing from mass politics, whether in the form of revolutionary 'terrorism' or Congress Party politics. They also caution us against drawing a line through the activities of the bhadralok despite evidence of numerous internal variations in their political and ideological affiliations and practices. 


\section{Hindu-Muslim confict and the CPI}

There is, finally, a third factor that made the CPI's ability to build a mass base in colonial Bengal more difficult. This was the factor of Hindu-Muslim conflict, which eventually tore the region apart during the 1947 Partition. As Lahiri (2001: xxiv) notes:

[E]xcept during the Non-cooperation-Khilafat movement in 1921, the participation of the majority of Muslim peasants was only marginal in the entire period of the national movement in Bengal. It was difficult, virtually impossible for the Communist Party of the Kisan Sabha to overcome this imbalance that had taken shape in the freedom movement from the very beginning of imperialist rule.

The effects of communalization upon class consciousness and class formation were acutely disorganizing in east Bengal where most smallholders were Muslims and landlords were Hindus. The Muslim peasants were gradually alienated from the Congress Party during the 1920s and 1930s because of its largely upper caste Hindu bias. Yet Muslim peasants joined radical peasant associations in large numbers, for example the Krishak Praja Party, founded in 1928. By the late 1930s, the Muslim League was the dominant political party among the Muslims. It attempted to block Muslim participation in the Kisan Sabha. In 1938, at the All India Kisan Sabha at Comilla in Bengal, the Muslim League scattered pages from the Koran on the road leading to the conference in the hope that Muslim peasants would refuse to trample on them and thereby be prevented from getting involved (Chaudhuri 1979: 351). As a consequence of the deep communalization of class conflict, in the aftermath of independence and the Partition, it was in the largely Hindu west Bengal and north Bengal that the CPI built its base.

\section{The tebhaga struggle}

At the outbreak of the Second World War, the CPI turned away from its earlier policy of unity with left forces within the Congress Party, and adopted a policy of prioritizing the 'revolutionary possibilities' opened up by the war. The task at hand was seen as 'the revolutionary utilization of the war crisis for the achievement of National Freedom'. A resolution adopted by the CPI Politbureau argued that 'the capture of power is an immediately realizable goal' (Overstreet and Windmiller 1959: 77). The result of this pronouncement was 'the most effective repression yet undertaken against the Communist movement in India' (ibid.: 183).

The tebhaga movement was launched during 1946, and it was strongest in areas where sharecropping was a prevalent form of subtenancy, with an immiserated class of tenants confronting a clear class division with jotedars. The adhiars, as noted earlier, cultivated land as tenants-at-will, taking half the share 
of the crop. The tebhaga demand was for a two-thirds share of the crop. This newly launched sharecroppers' movement was immediately suppressed and forced to retreat (Sen 1972: 28). As the peasant leader Sunil Sen recalls, the kisan (peasant) movement 'was virtually driven underground ... [and] there was considerable demoralization after the collapse of the adhiar movement' (ibid.: 29). The next successful campaign the CPI could undertake in Bengal was among sharecroppers in 1946-47 (known as the tebhaga revolts). This was largely centred in the areas where the BPKS campaigns were concentrated between 1936 and 1940 .

\section{Conclusion}

The analysis in this chapter reveals that the different strategies of the CPI (in Bengal) and CSP (in Kerala) within the nationalist movement mattered to some extent in determining their eventual trajectories, organizational strength and political ascendancy in the respective regions. However, the actual practice of implementing these strategies depended to a large extent upon the concrete 'objective conditions', the set of political relations within which each party was embedded. Thus the CSP's strategy of working within and 'transforming' the Congress Party had a greater chance of succeeding where the Congress Party was ripe for a 'take-over' and had a prior history of participation in popular struggles (such as the lower caste movements in Kerala), that could be redefined by a more radical agency such as the CSP. But in Bengal, where the conditions were somewhat different, and where the Congress Party was led by the landed classes and leading industrialists, such a strategy (or even a less ambitious one of restricted participation in Congress campaigns) may well have failed in building the CPI. The alternative, of working outside the Congress mainstream as communists was equally difficult because of the severely anti-communist bent of the colonial state, and thus their perpetual 'underground' status. In this respect, the Bengal communists faced the dilemma of attempting to chart a path within the ambit of the repressive arm of the colonial state on the one hand, and GandhianCongress hegemony on the other. This dilemma meant that the party's cohesiveness was always in question. Each of these factors, together with the increasing communalization of the class divide between Muslim peasants and Hindu landlords, affected the ability of the CPI to grow into the kind of hegemonic party that the Kerala CSP (and CPI) had become by 1940 .

These differences between the two cases would appear to suggest that the Bengal communists would have had a poorer capacity to implement reforms, if any at all, were they able to dominate the government in the post-independence years. That Bengal's communist party should have come to dominate the government for five decades at a stretch after 1977 would have greatly surprised to an observer in the 1940s. However, the party was able to grow exponentially during the mid- to late 1940s as a direct result of their adoption of the People's War line, and their rehabilitiative and relief efforts during the famine of 1944. But 


\section{Weak left hegemony in Bengal}

in comparison with Kerala, the growth of the communist party at this stage did not embed it sufficiently in civil society. The organic development of Kerala's communist movement allowed it - or produced a disposition within it - to carry out hegemonic projects regardless of its dominance or otherwise in the electoral sphere, while in Bengal the electoral sphere became the point of reference for its extra-parliamentary activity - this set of circumstances can be traced directly to the conditions of its origins. This point is taken up at greater length in the following chapter. 


\section{Insurgent and electoral logics in policy regimes \\ Kerala and Bengal compared, 1947 to the present}

This chapter establishes the important effects of prior movements and patterns of state formation upon the social policy regimes that developed in Kerala and West Bengal in the post-independence era. A 'policy regime' is a 'situation ... in which major parties, regardless of their partisan stripes, propose and implement similar policies' (Przeworski 2000). This means that policies become taken-for-granted and despite ideological differences opposing parties and governments cannot easily remove them. The institutionalization of a policy regime is the product of what Jessop (1990) has called a 'hegemonic project' of parties and movements, that is, their ability to exercise moral and political authority in claiming the centrality of equality-enhancing or redistributive policies (or their opposite, as the case may be). In Kerala, beginning from a position of greater strength, and a hegemonic claim to represent the interests of agricultural labourers, poor tenants, lower castes and some sections of the middle classes, the left initiated a social policy regime that surpassed the regime initiated by the communists in Bengal over several decades of dominance. But the communists in Bengal have also avoided many of the problems of their Keralan counterparts. First, they have ruled more consistently for an unbroken six terms. They have tackled crucial issues of land control, implemented local government councils, and have managed to keep relatively high rates of economic growth in the rural sector. Yet their success in reducing forms of poverty, measured in terms of Sen's index of 'capabilities and functionings', is not as marked as in Kerala.

The different policy regimes reflect the relationships between state formation, pre-independence party formation in the two states, and in turn the effects these had upon the functioning of parties in the post-independence parliamentary arena. The politics of electoral mobilization and coalition formation, combined with competition from other parties, has radically tempered social policy efforts in both Kerala and Bengal - indeed, this is a key factor that draws the ire of left commentators and scholars, who suggest that the parliamentary left has been reduced to an impotent force for change (see Mallick 1993). This appears to support a more general argument, namely, that the extension of political rights to civil rights, and the democratic political revolution (bourgeois revolution) to the social realm, is the purported task but almost irresolvable dilemma of socialist 
parties that seek to work within the framework of bourgeois democracy. Przeworski and Sprague (1986) argue that this dilemma arises for structural reasons - when workers do not form a majority, socialist parties simply dilute their agenda in order to win elections. For two revolutionary parties that are premised on the theory of working class leadership, the necessity of forming coalitions with a variety of parties in largely pragmatic fashion has resembled the dilemma posed by Przeworski and Sprague. Yet if the horizon of political change is unhitched from the now meaningless dichotomy of 'revolution' vs. 'reform' we have only to ask whether the very real strides made in the life chances of its citizens in Kerala itself constitutes a real horizon of sorts, an example of 'real utopias' in the making (Fung and Wright 2001) under the very difficult conditions that confront democratic, leftist third world regimes.

The differences between Kerala and Bengal highlight the possibilities and limitations that confront such democratic regimes, and suggest how these limitations can be confronted. In Kerala, the well-developed hegemonic capacity of the communists grew out of what I describe as the 'insurgent' logic of the late nationalist movement, rather than solely the 'electoral' logic of the postindependence era. In other words, the Kerala left had grown as a movement steeped in many different aspects of democratization ranging from caste, land struggles, labour struggles, social reform, intra-family reforms and anti-colonial struggles. Its capacity to reform when in power was a function of this insurgent logic. This capacity revealed itself particularly in the set of policies the communists implemented during their first parliamentary stint in the postindependence period from 1957 to 1959 . These policies were the most radical that were ever implemented by any left party in India (indeed anywhere else globally) through democratic means. In Bengal, given the prior organizational weakness of the party, and its largely non-hegemonic character until the 1960s, the framework of post-colonial bourgeois democracy within which the communists attempted their ascendancy determined their particular strategies of formulating social policies. These were largely related to the question of agrarian class relations, and class formation among the sharecroppers - extending struggles that the communists had carried out during the 1940s. Universalistic welfare policies, such as public food distribution, post-natal care, literacy and provisions for old age, were prioritized far less; neither were there popular movements that pushed for these reforms as there were in Kerala. Here, the reforms that the communists attempted during their first ministry, and subsequent reforms in the next two decades, reflected struggles from the immediate past, and in turn ushered in a policy regime that other subsequent ministries could not easily roll back. Moreover, since they faced fierce electoral competition, Kerala's communists spent as much time out of power as in government. During their extraparliamentary tenures, the Communist Party of India (Marxist) (CPM) pursued a strong insurgent policy against several targets that included landlords, capital, and opposition parties and unions run by them. They used tactics of strikes and popular protests to push for the implementation of radical legislation. These 
tactics were used by the communists in Bengal until they won elections, but for most part in Bengal the hegemonic capacity of the left was built through electoral domination rather than widespread civil society penetration through popular movements. ${ }^{1}$ In the absence of any significant opposition, that is, electoral challenge from the right or from other left parties, the Bengal CPI has ruled consistently (now for six decades), and the lines between dominance and popular hegemony have been blurred.

Indeed, the Bengal communist party, by virtue of weaker links with different forms of popular associationalism, ranging from literacy groups, popular science movements and lower caste associations among the poor (for reasons outlined in earlier chapters), possesses a weak 'capacity' for the kind of 'infrastructural penetration' that is necessary to reform inequality and poverty. The concept of capacity is often reduced to something like 'will' but there has been little social scientific attention to what is really meant here. The analysis presented here suggests that the capacity of states is a consequence of not only the bureaucratic machinery, and/or repressive apparatuses, but in a more positive sense also the push of social movements in democratic contexts. $^{2}$

This chapter begins, however, with an empirical puzzle - Kerala's left has held power far less consistently than the left in Bengal, which at the time of writing has completed twenty-five years of unbroken rule. If we recall the findings from the previous chapter, Kerala's communists should have been poised for political dominance, while the weaker party in West Bengal should have been unable to remain the single dominant party. The puzzle deepens when we consider that despite being ousted from power by the central government, and defeated in elections several times by a strong opposition coalition, Kerala's left governments have been more consistently activist and, propelled by affiliated movements among poor tenants and workers, they have implemented more farreaching anti-poverty policies than the West Bengal Left Front governments. Conversely, single-party dominance in Bengal has not produced the depth of reform that might be expected. This calls attention to the need to address difficulties with the theory that party dominance is crucial to a strong reform agenda (Pempel 1990). Party dominance may of course help a party see through its agenda, but as the evidence here shows, the determinants of its ability to press radical reforms lie in antecedent sequences of structure-event interactions.

Atul Kohli's (1987) comparative study of anti-poverty policies in four Indian states is particularly relevant for the argument of this chapter. Arguing that 'a degree of separation between social and political power ... [makes] ... the pursuit of reformist policies possible' (1987: 230), Kohli emphasizes the organizational cohesion of the state (which he treats as synonymous with the party in Bengal) as a key factor in social democratic reform. He treats Bengal's communist party (CPM) as an exemplary regime which, he argues, displays the essential characteristics of a coherent and stable leadership, a 'pro-lower-class ideology' and democratic centralist principles which lend it organizational cohesion and power. These features have made it possible for the CPM in Bengal to gain 
autonomy from the dominant classes to a degree not achieved elsewhere. In this chapter, the activities of the Bengal CPM are compared with those of the CPM in Kerala - both of which have achieved autonomy from the dominant classes to an extent, but in Kerala, the party has been a greater instrument for structural change than in Bengal through a wider web of social policies. The differences between the two cases help us develop Kohli's theory further by specifying the role of social movements, and the porosity of the line between party and movement as a crucial axis of social democratic reformist power.

The CPI (and later CPM) in Bengal built itself much later than in Kerala, not having achieved the mass base and degree of hegemony that the Kerala CSP did before independence in 1947. To compound its late fruition into a mass-based party, in 1964 intra-party crises plagued the Indian communist movement ${ }^{3}$ (the left faction known as the CPM came into power in Bengal subsequently), and the communists in Bengal had to rebuild their party units and forge new political alliances. Most of the party recruits and leadership came from displaced middle class migrants from East Pakistan after the Partition of 1947, who were drawn to the communist party in the ensuing political flux. While the communists in Kerala had to contend with the party split emanating from national-level decisions, the longer history of mobilization and organization in the region, and a firmly consolidated base among the poorer rural and urban classes, did not affect the larger of the two communist parties, namely, the CPM, which drew most of the leadership and cadres from the former CPI and CSP. By then the communists in Kerala had already won state elections twice (in 1957 and 1967), and implemented far-reaching land reforms and social policies concerning education, health care, housing and public distribution of food grains. This chapter will argue that Kerala's reforms followed from phases of insurgency led by the left itself, both in its capacity in the government, as well as in its extraparliamentary capacity.

Before we begin with their respective records in power, we must ask how the prior organizational legacies and differential degrees of hegemony of the two communist parties affected their practices in power. In particular, how did the party in Kerala, in conjunction with trade unions, peasant organizations and other popular organizations, employ a twin strategy of electoral and extraparliamentary struggles to create a social policy regime that surpassed that attempted in any dependent-developing context, and why did this not happen in West Bengal? This involves an examination of the differences in the structure of choices available to the communist parties in Kerala and West Bengal at the onset of their tenures, as well as the relatively autonomous role of politics. In the new conditions of post-independence India, new factors entered the 'political opportunity structure' for left parties, and shifting structural conditions necessitated new strategies. The manner in which they availed themselves of these choices differed significantly - and led to very different capacities for electoral victory. 


\section{The contexts for leftist policy reform: Kerala and West Bengal compared}

The CPM in Bengal first came to power in 1967 after the undivided CPI had split into the left CPM and its 'right' counterpart (which retained the name of the CPI). While in Kerala the CSP had merged with the undivided CPI in 1940, and went on to win district elections in Malabar as early as 1951, in Bengal the CPI was politically insignificant until 1967 when it formed its first state government in coalition with the CPM, CPM-L and other smaller left parties such as the Praja Socialist Party (PSP) and Samyukta Socialist Party (SSP). In 1952, 1957 and 1962, the percentage of seats contested by the CPI were 36 per cent, 41 per cent and 58 per cent respectively, and the percentage of seats won were 11 per cent, 18 per cent and 25 per cent respectively, suggesting an expanding base. In 1962, however, although the CPI was the second largest party in West Bengal, it was easily overshadowed by the Congress Party which won 62 per cent of the seats contested and received almost half of the total vote. As Weiner and Osgood (1974: 9) noted: '[p]erhaps the most striking feature of the Communist electoral effort in West Bengal is how limited it has been.' If so, then the question is how did the CPM win an electoral majority in 1967 and come to hold power in an unbroken continuation of terms since 1977? What kinds of strategies and tactics of struggle did it employ to win power, within what kinds of objective constraints and circumstances? Addressing this question can help us better grasp what kinds of constraints communists in Bengal faced when they came to power, and how these compare with those in Kerala.

Although it is commonplace to counterpose the violent insurrectionary tactics of one part of the left to the 'reformism' of the other, that is, to draw a clear distinction between the armed insurrectionary tactics of the Maoists (from the CPI (M-L)and the electoral strategy of the centrist CPI and CPM, it is important to recall that a large number of the future CPM leaders and activists in Bengal not only came out of violent 'political sects', but many of them had explicitly advocated the use of violent tactics against the Indian state and 'landlordbourgeois' coalition. In 1948, under the insurrectionary line of B.T. Ranadive, the communists demonstrated their ability to whip up a militant demonstration of worker and peasant strength. Although almost 3,000 communist activists were arrested, the prior activities of communists had strengthened their base in both Kerala and Bengal. In Kerala, the militant mobilization of tenants over common lands in Malabar, campaigns against the hoarding of food-grains and ongoing struggles for temple entry in Cochin utilized tactics of direct confrontation such as land invasions, strikes and insurrections. The famous Punnapra-Vayalar revolt, in which almost 2,000 striking coir workers attacked police stations in Travancore, with about 300 of them being killed in the ensuing battle, together with the strong reputation the communists had gained as a party of honesty and dedication, allowed them to prevail and grow, despite the arrests and crackdowns that occurred between 1948 and 1950. Indeed, in Kerala, the famous struggles of Alleppey and Shertallai, in which thousands of workers burned bridges, 


\section{4}

blockaded roads and engaged in a violent demonstration of their strength, are still mentioned as a crucial legacy of the party.

In Bengal, communists led urban and rural insurrections, particularly in the southern and south-western districts of Midnapore, Howrah, 24-Parganas, Bankura and Burdwan. These regions were to be the emergent areas of electoral strength for the communists in 1952 (Ghosh 1981: 20). In that year the Congress Party won state elections in Bengal with 63.4 per cent of the seats in the State Assembly. It won the majority of seats in Muslim-dominated areas, won all the seats reserved for the scheduled castes and tribes, and eighteen constituencies with labour majorities, out of a total of twenty-one, voted for the Congress Party. This was a formidable electoral opposition for the communists, who began for the first time to pursue a coalition strategy for winning elections. In 1957 the communists fared better (raising their seats from twenty-eight to forty-six), even though the Congress Party had won the elections.

In the meantime the CPI national leadership had been moving closer towards a more 'moderate' line. If one motive for this shift was the realization that an insurrectionary strategy of violent mass agitations could break the back of the party, another came from having seen the exceptional experience of Kerala's communists with the electoral path, which tilted their strategy even closer towards fighting elections. This development in Kerala dated back to the 1930s with the communists' experience as members of the CSP in winning elections under the umbrella of the Congress Party. In 1954 communists contested and won elections to the Malabar District Board, taking twenty-four out of a total of fortyeight seats. Their experience with district government was successful. During its tenure, the CPI established single teacher schools in remote areas of Malabar, upgraded elementary schools and outlined norms for the transfer of teachers. In addition, it organized frequent press conferences, encouraging people to come forward with their complaints to the district board. While holding positions of power, the communists also demonstrated their personal frugality, travelling by ordinary buses and third class compartments in trains (Nair 2001). ${ }^{4}$ These achievements and their reputation for honesty won the communists an award for model administration from Jawaharlal Nehru, India's first Prime Minister. The 'centrist' position proposed by the leading Kerala communist, E.M.S. Namboodiripad, within the national communist leadership was undoubtedly stronger because of the demonstrated success of this path within Kerala. The new line of parliamentarianism now demanded sustained but disciplined mobilization, and adherence to 'bourgeois constitutionalism', even if it was to be occasionally side-stepped.

In Bengal, the prior weakness of the communists in terms of organizational strength and degree of penetration of civil society was compensated for by their growth between the 1957 and 1962 State Assembly elections. The communists made greater incursions in rural areas, moving from being a predominantly urban party to a party with a sturdier rural base. Most of their support came from the sharecroppers, whose rights to the land were slowly beginning to come under the 
purview of state legislation. In areas in which the communists had led insurrections between 1948 and 1950, namely, Bankura, Burdwan, Midnapore, Howrah and the 24-Parganas, the communists were particularly successful at winning seats. The relationship between insurgency and electoral success was causally similar to that in Kerala.

The state-level success of the communists was obstructed at this point by ideological differences that appeared at the pan-Indian level. By the early 1960s internal divisions within the CPI were becoming increasingly salient. The division was ideological and strategic, between those who wanted to maintain their policy of mass struggles under 'leadership of the working class', and those who felt that a broader class alliance and parliamentary strategy was the way forward. Later, these differences were to translate into the split between the CPI and CPM, with the CPI adhering to the class alliance line that included strategic alliances with the 'progressive section' of the bourgeoisie represented by the Congress Party, and the CPM advocating mass struggles 'from below' and repudiating any alliance with the Congress Party. In Bengal, the CPM continued its earlier policies of leading mass struggles in rural areas among sharecroppers, and among workers in the cities. In 1967 it won state elections for the first time in Bengal, but this victory was in large part because of a decline in the vote for the Congress Party, which was picked up by the Bangla Congress Party (a dissident faction that had broken off from the Congress in 1966). The communists' total share of the vote had not increased between 1962 and 1967 (in 1967 it was split between the CPI (7.35 per cent) and the CPM (17.77 per cent)). ${ }^{5}$ At this historical moment the difference in the situations of the Kerala and Bengal communist parties at their first electoral victories was striking. The fourteenmember coalition that came into power in Bengal had begun to collapse within months, in no small part as a result of internal contradictions that clipped the edges of CPM radicalism. Bengal was in the midst of near-famine conditions (as were large parts of the country), and the communists had the opportunity to demonstrate their ability to solve this crisis. However, the Food and Agriculture Minister, C. Ghosh, an independent candidate, opposed the forced seizure of grains from landlords, instead turning to the central government for food aid. Because of political hostility to communist rule from the centre, only 70,000 tons of grain had been collected against the target of 200,000 tons (Mallick 1993: 104). The contradictions of a coalition government were clear - the communist solution would have been to seize grain from the jotedars but they formed the chief political base of the coalition partners. To make matters worse, there was a corresponding rise in industrial unrest that led to widespread closures of factories. On 20 February 1968 the central Congress-led government imposed President's Rule after considerable infighting among the United Front partners.

As luck would have it, although the Congress Party had the opportunity to utilize the imposition of President's Rule in Bengal, they failed to win the next round of elections. In 1969 the communists formed another United Front, this time one that was more to the left, signifying a shift in the balance of power 
within the CPM. As numerous sources on this period testify, violence on the part of the communists played a crucial role in winning this dominance. Concretely, this meant that the next few years saw a more radical policy of mass movements, led by Harekrishna Konar; they focused, in particular, on rural sharecroppers' struggles rather than on the industrial front. Rather than allowing government officials to serve as intermediaries in taking possession of the land, peasants directly took the initiative (Mallick 1993: 131). There were violent seizures of land, with roughly 1,000 cadres forming rural volunteer corps, each consisting of from five to ten militant peasants (Basu 1982: 87). In addition, within the Bengal CPM further splits had begun to occur between the parliamentary 'centrists' and Maoist revolutionaries (also known as Naxalites), who had launched a peasant insurrection in the areas of Naxalbari, Kharibari and Phansidewa. This brought about an unprecedented situation, in which a left government in power entered into forced confrontation with a faction within its own party, and used the police and paramilitary forces to repress it. The Naxalites conducted peasant revolts across West Bengal, as bands of revolutionaries armed with bows, arrows and spears, let loose a violent campaign of killing landlords, police and government officials. The Naxalites were also active in other parts of India - notably in Kerala and Andhra Pradesh - but in Bengal, the revolt assumed serious proportions, for the party split was attended by a class split in the base of the CPM. The dilemmas of forming cross-class alliances, then, could not have been more acute. The CPM appeared more and more as a party of middle class bhadraloks who held together an alliance of middle, small and landless peasants, but the latter were the least important part of their strategy. There were, for example, no records of agitations for the landless in 1967-68 in West Bengal (Basu 1982). Indeed, the newly formed Naxalite presence meant that the CPM had to struggle within the party over fundamental issues of strategy and tactics, which apart from throwing the leadership into disarray also split its base. When the Maoist threat was no longer a real one, the CPM reverted to a more moderate electoral strategy, aimed largely at perpetuating its parliamentary victories.

\section{Party and insurgency in the implementation of land reforms in Kerala and Bengal}

Land reform is a state government responsibility, and following the extent to which it has been lifted off paper and actually implemented allows us to track the effects of local state regimes upon inequality. Indeed, in a primarily rural country, land reforms are a key policy instrument for achieving the objectives of growth as well as redistribution. Although land reforms have all but disappeared from development discourse, it remains underappreciated just how important their implications are in resource-poor, but primarily agrarian, economies. Likewise, land ownership inequality and landlessness are crucial measures of inequality.

One of the most important aspects of social change that occurred in Kerala after independence was its land reforms. These had been a long time coming - the 
political struggles that went into the making of the left as a concrete organization and its involvement in land agitations since the 1930s, mandated that land reforms were a first policy priority. These, moreover, addressed the situation of the poorest agricultural households as well as agricultural labourers, both because the communists had built a base among these classes and because they were a mobilized and organized constituency from the 1940s.

Thus during the 1950s the Malabar peasant organization (Kisan Sangham) continued its earlier agitations for securing permanent rights for tenants, cancellation of debt arrears and distribution of fallow land. In 1952 the tenants' union demanded the amendment of the Malabar Tenancy Act of 1929, facilitating the 1954 amendment, which prevented the eviction of all tenants including inferior tenants. In addition, a Rent Courts system was introduced as a direct result of the agitations, which was an important forerunner to the popular participation of poor tenants in the implementation of land reforms through land tribunals.

Unions of agricultural labourers were formed in Kerala as far back as 1939, as an integral part of the caste-class organizing strategies of the CSP. As Alexander (1989: A-73) notes, '[t]he history of the Travancore Agricultural Laborers' Union to a great extent is the history of the Communist Party in rural areas of Alleppey'. Labourers had made classically proletarian demands such as better pay, improvements in working conditions and security of employment through strikes in 1941, 1952 and 1954. They had demanded higher wages, regulation of working hours and had struggled against landlords' refusal to pay agreed wage rates. All of these prior demands of the agricultural workers were addressed in the Agrarian Relations Bill of 1957. The debt-bondage, serf-like relations that bound landless labourers to landowners was explicitly addressed by granting security of housesites and prevention of eviction (Herring 1983: 169). Within a week of forming its ministry in 1957, the CPI proclaimed a Stay of Eviction Proceedings Ordinance to protect tenants and labourers with huts on landlords' lands. The Land Reform Bill was made public, and Karshaka Sanghams (tenants' associations) were invited to help draft its provisions. The most downtrodden and lowly rural classes, once subject to the personal whims of upper caste landlords, now had their own plots of land. They were entitled to their own hutment land, and given the option of purchasing one-tenth of an acre at one-eighth of the market price (Lieten 2002b).

The long history of organization of agricultural labourers had begun to pay off by the 1960s in the form of higher wage rates. Between 1964-65 and 1969-70, the agitational activities of labourers under their unions had led to a 140 per cent increase in money wages (Alexander 1989: A-73). Later, the Kerala Agricultural Workers Bill, introduced in 1972 and passed in 1974, addressed the insecurity of employment and wages, with the result that wage rates in Kerala, relative to productivity, have been the highest in India. This classic bill, sometimes referred to as the Magna Carta of the agricultural workers, has been as much as the product of an activist government as of organized union activity. 
Wage policies for agricultural labourers were in lieu of any greater redistribution of land. Because, as Herring (1983) notes, the policy logic of land reform was 'anti-feudal', but explicitly promoting capitalist relations in agriculture, the ceilings on the land were in fact too high to appropriate sufficient land to redistribute (15 acres for double-crop paddy, 22.5 acres for single-crop paddy, 15 acres for garden land and 30 acres for dry land). The bourgeois constitutional framework diluted the land reforms in several respects. First, the government was constrained in attempting outright confiscation of landlords' lands without compensation, despite their firm opposition to it in principle (Herring 1983: 166). Second, the idea of 'land to the tiller' was modified in reality to include those who supervised labour; Herring argues that this was necessary in view of the tactical line of abolishing feudalism. All non-feudal classes had to be aligned behind the reforms. Third, apart from the high ceilings on land ownership, the plantation sector was exempted from reforms. Thus 'small owners' were exempt from the tenancy laws, that is, tenants of such lands were not qualified to claim ownership rights, and could, moreover, be evicted if the owners chose to resume cultivation of the land themselves (Pannikkar 1975: 60). Likewise, exempting plantations, cashew estates, religious and charitable institutions from the reforms meant that almost 10 per cent of the total land was left out of the purview of legislation.

All these caveats were made by the communists with the awareness that they were working within a federal system, and that the class alliance upon which their own hegemony was built was a fragile one, liable to implode if policies were 'too radical'. Indeed, in 1959 they were confronted with growing outrage against their land reforms and education policies. A coalition of landlords, the Christian Church led by a Catholic anti-communist priest, Father Vadakkan (who later shifted over to sympathizing with the left), and upper caste groups, primarily the Nair Service Society, led violent street demonstrations, marches and various protests, calling for an end to communist rule. Using large-scale civil disobedience and efforts to paralyze the administration, they were able to bring the full force of democratic freedoms to bear on a popularly elected left. They were powerful enough to finally persuade the President to intervene and impose President's Rule. In the next elections, despite the communists winning a larger share of the popular vote than before, the opposition parties won a majority of the seats and a Congress-Praja Socialist Party alliance formed the government. This victory had the effect of mobilizing landlords as well as tenants and poor peasants - each side agitating for their interests. Lieten (2002b) points out that although the CPI lost the elections, it increased its base from 40.7 per cent of the vote (in 1957) to 43.1 per cent of the vote, in part due to a 38 per cent increase in voters' turnout. The increase in voters' turnout was itself a result of the politicization of the electorate. For reasons of space, it is not possible to chart the complex twists and turns of communist electoral victories and defeats in Kerala (see Nossiter 1982 for an in-depth account). 
The politicization of the electorate and the rise in political consciousness that continued despite the instability of government meant two things. On the one hand, being in and out of power prevented the communists from fully implementing land reform legislation. The opposition was forced to carry through aspects of the reforms, but these were watered down. The Kerala Agrarian Relations Act of 1960 dropped some provisions that were present in the earlier bill; these included keeping 'hutment dwellers' out of the category of tenants who were to be protected from eviction, further concessions to plantation owners (Pannikkar 1975: 61). However, in 1963 the Kerala High Court declared it ultra vires of the Indian Constitution. It was in 1964, almost seven years after the original proposal, that the Kerala Land Reforms Act was finally implemented, and in 1969 tenancy was finally done away with as a left coalition came back to power. This evidence suggests several things of importance. First, the competitive nature of parliamentary democracy in Kerala has kept left parties from fully implementing their agenda at critical points. However, their social base and 'hegemonic disposition' has allowed a distinct policy regime to emerge, one that has, despite its shortcomings, surpassed that anywhere else in India. Thus on the other hand, various scholars and commentators are agreed on the fact that while the task of redistribution could never be fully implemented as long as there was a strong opposition (lacking in Bengal, as we will see) and a national government hostile to the left, communist rule was critical in breaking down the patron-client ties, debt-bondage relations, and casteist oppression that continues to plague many other states of India. The security of tenure to former tenants-at-will took a giant step towards reducing inequality, although it is unlikely that one or two sets of reforms could make a sufficient dent in the centuries-old institutionalization of inequality. However, equally important were the mutual feedback effects of party strategy, policy and popular mobilization, which came to be the hallmark of policy reform in Kerala. The mechanisms that made this possible were clearly both parliamentary and extra-parliamentary, that is, the introduction of legislation as a dominant party became a rallying point for raising class-consciousness, forming organizations and placing concrete demands that could alleviate poverty and inequality in the immediate foreseeable future. However, undoubtedly, the most crucial factor driving the radical character of the first regime-generating policies of 1957-59, was the close relationship between party formation and the mobilization of the low-caste and working poor in Kerala.

Ironically, in Bengal, consistent rule in the context of weak opposition has not been matched by a strong reform agenda. The circumstances inherited by the communists were distinctly unfavourable. As Gazdar and Sengupta (1997: 132) argue:

About the only favourable feature of the Left Front's inheritance in 1977 was its reasonably assured political base. The negative features of this inheritance were far more overwhelming - high rates of rural poverty, stagnation in agriculture, demographic pressure, and a declining industrial 
sector. These problems dated far back to the British era, but Partition in 1947 worsened the economic situation by disrupting transportation, communication, power projects, and not least of all, the unprecedented flow of refugees on both sides of the border.

In particular, they estimate that over one-third of the rural population was landless, possessing no rights to the land. Moreover, these households were concentrated in the western districts of Bengal, which eventually constituted the state of West Bengal.

In Bengal, middle peasants stood to gain the most from the land reforms (eradicating sharecropping), while poor and agricultural labour households who had no land to begin with were not so well compensated. Agricultural labourers in Bengal did not have the history of militant activism that their counterparts had in Kerala. A relatively weak reform, brought about by a high land ceiling, consolidated the communists' base in rural areas among the 'middle' peasants, while the historically demobilized agricultural labourers and poor peasants remained so. An electoral logic of growth and party hegemony did not require communists to risk such mobilization, which would in all likelihood challenge their own base.

The politics of coalition, in which the communists have been particularly successful, has made the search for broader class alliances less relevant to their strategy. Thus, as Mallick (1993) points out, by the time of the Left Front government's first electoral victory land ceilings were already in place, all but eliminating the remaining minority of large landlords (zamindars). The United Front coalition of the CPI and other smaller parties, which was elected in Bengal in 1967, fought the election and won on the basis of their plan to implement the first stages of a land reform that would transfer land to the sharecroppers and give them ownership rights. Land ceilings were lowered from 25 acres per person, allowing a household of two to five persons up to 12.35 acres of irrigated land, or 17.39 acres of unirrigated land (Gazdar and Sengupta 1997: 143). Mallick argues, however, that the 'middle peasants' were the only category from whom land could be appropriated for redistribution, but they also constituted the political base of the communists. Thus greater mobilization of agricultural labourers and small cultivators would unsettle this party-base nexus and potentially drive the communists out of power. In Mallick's words, '[s]ince organization of the lowest strata is weak or non-existent, the safe option is for the Communists to soft-pedal serious and meaningful attempts at land redistribution' (Mallick 1993: 30). According to figures provided by Mallick from the Agricultural Census of 1976-77 (Government of West Bengal), the 'semimedium' and 'medium' landholders who own between 2-4 hectares and 4-10 hectares of land, as well as a minority of landowners who own more than 10 hectares of land together constitute roughly 55 per cent of the total agricultural population. However, since the land ceiling is 10 hectares, this leaves insufficient land available for redistribution to poor agricultural households. In a self- 
admission of the inadequacy of its policy, the CPM Central Committee blamed the inertia of the West Bengal land reforms upon the fact that the party was based upon 'the rich and middle peasantry, instead of ... the rural labour and the poor' (Communist Party of India (Marxist), Central Committee, 'Tasks on the Kisan Front' (Calcutta, April 1967), cited in Mallick 1993: 41).

In the first twelve years of communist rule, only 200,000 acres out of $1,249,117$ acres of land had been vested, the rest having been vested under Congress governments. The land ceiling laws implemented in 1972 were supposed to yield a surplus of 3 million acres of land; however, in reality only 40,000 acres were actually distributed (Kohli 1989: 121). A large amount of land had been redistributed under communist rule between 1967 and 1969, however, and a critical point regarding this is that peasants had been encouraged by the communists to grab the land themselves, without waiting for the administration and bureaucracy. Moreover, the vesting of land under Congress governments had been pushed by communist-led movements of peasants and agricultural labourers. Gazdar and Sengupta (1997) note, in contrast, that the post-1977 approach of the Left Front to land reform was more bureaucratic than before. Instead of the direct involvement of peasant organizations and movements, it was largely local government bodies that were now leading the process. Indeed, the contrast with Kerala is also evident here, in so far as the communists' base among both the agricultural labourers and small tenants precluded such policy dilemmas, at least until the 1970s. Then, the former tenants who had benefited from land reforms became the new class antagonists of the agricultural labourers. However, in Kerala, admitting that they could not redistribute more land, the communists attempted strategies to redress low wages, dependency and insecurity throughout the 1970s through various kinds of legislation, as well as developing an extensive social security network.

A detailed study by Gazdar (1992) of six Bengal villages under Left Front rule reveals that caste continues to be a predictor of poverty, land ownership and education, despite rounds of land reforms. While he argues that the position of scheduled castes and tribes has improved through land reforms, statistics show poor results in other areas of social policy regarding the historically poorest strata.

\section{The politics of literacy}

The education and literacy policy of the communists in Kerala has been aimed at extending primary schooling to broader sections of the population, and indeed, universal literacy is the clearest example of Kerala's policy achievements. As we have seen, however, Kerala had an early lead in its literacy rates because of state reforms initiated during the late nineteenth century by the Travancore state. This policy legacy was undoubtedly a crucial determinant of communist policy, as access to schools and the reform of education had been highly politicized all along. In 1957 one of the CPI's policies that was to lead to violent protests and 
the ousting of the undivided CPI in 1959 was the Education Bill. Most of the schools responsible for Kerala's prior legacy of high literacy were private, ecclesiastically managed schools (dominated by the Syrian Christian Church). The CPI government viewed them as webs of profiteering, which had become alternative sources of a power base (not created by a weak industrial bourgeoisie) (Lieten 2002b). Moreover, as noted in Chapter 2, the schools had distinctly favoured the education of the upper castes and Christians; the Ezhavas, Muslims and scheduled castes who constituted 65 per cent of the population were poorly represented in the education system in comparison. Over half of the scheduled castes, and 64 per cent of scheduled tribes were illiterate, while among Ezhavas and Muslims 31 per cent and 44 per cent respectively were illiterate (ibid.: 35 ). The Education Bill sought to do what the earlier Travancore and Cochin states had attempted but failed to do in the face of agitation by the Christian Church namely, to make education a state responsibility. The improvement of the poor salaries of teachers and the adequate redressal of their grievances had been a major electoral promise of the CPI, based no doubt on the fact that young teachers formed an important source of support for the CPI. The Bill called for greater security for teachers, by making their arbitrary dismissal illegal, and stipulated that all salaries would be paid directly by the government. The result of the CPI's Education Act, the growth in the number of government schools and rise in education expenditures, as well as the dramatic growth in popular consciousness around the issue of literacy, was a rise in the rate of literacy increase in Kerala. Between 1951 and 1971 female literacy in Travancore and Cochin increased from 37 per cent and 35 per cent respectively to 61 per cent and 59 per cent, while in Malabar it went from roughly 22 per cent to 44 per cent (the fastest rate of increase) (Lieten 2002b: 55). Similarly, death rates fell more sharply during this period than at any previous time (ibid.; Kumar 1982). The 'crude death rate' declined from 16 per cent to 8 per cent between 1961 and 1971, a large part of which was due to the fall in the infant mortality rate (Lieten 2002b: 54). The spread of health care combined with its use, and the possibility of popular education regarding health issues, were together responsible for this decline in death rates, as well as infant and maternal mortality rates. This latter is due very clearly to the spread of literacy among the poorest lower caste agricultural workers and peasantry.

The increase in literacy, of course, followed directly from increased enrolment in schools. For instance, enrolment in public schools at the secondary level rose almost four times from 1957 to 1975 . Moreover, the female literacy rate almost doubled between 1961 to 1971, with the most dramatic increase being in Malabar (in the district of Kannur, female literacy rose by 121 per cent, and male literacy by 99 per cent) (ibid.: 56-57).

Table 6.1 shows quite clearly that the breakthrough period in literacy rates began with the changes initiated during the communist ministries of 1957-59, with literacy rates almost doubling in some districts during the 1960s. In the case of schools, communists had decided to prioritize the spread of government 
Table 6.1 Trends in Kerala's literacy rate by district, 1961 and 1971

\begin{tabular}{lll}
\hline & \multicolumn{2}{c}{$\%$ literate to total population } \\
\cline { 2 - 3 } District & 1961 & 1971 \\
\hline Kannur & 27.8 & 55.3 \\
Kozhikode & 28.3 & 58.8 \\
Palghat & 25.2 & 46.7 \\
Thrissur & 32.1 & 61.6 \\
Ernakulam & 34.0 & 65.4 \\
Kottayam & 36.2 & 72.9 \\
Alappuzha & 39.9 & 70.4 \\
Kollam & 34.7 & 65.0 \\
Thiruvananthapuram & 30.1 & 62.5 \\
Kerala (overall) & 31.9 & 60.4 \\
\hline
\end{tabular}

Source: Lieten 2002b.

schools to all citizens, and the rise of literacy rates in Malabar is probably the most crucial evidence that the prior regimes of Travancore and Cochin were not the only cause of Kerala's distinctiveness. Nevertheless, the emphasis on education reflected a long history of state involvement in literacy, as well as lower caste demands for schools. The poorer provision of schooling for lower caste children in Bengal, as discussed below, stands in marked contrast to that in Kerala.

The Education Act was not the only policy instrument used by the CPI to secularize and regulate education, and thus make it more available to the lower caste poor. During the 1970s and 1980s, the Kerala Shastra Sahitya Parishad (KSSP) launched a series of literacy drives during the tenure of the left-CPM, to take literacy to the villages through the activities of thousands of volunteers. The KSSP was founded in 1962 as part of a People's Science Movement, which sought to spread science and rational thinking in order to undermine casteism and superstition. Its growth and continuing affiliation to left party growth and strategy-making is evidence of the left's deep civil society penetration as organization and movement. The KSSP has undertaken thousands of literacy drives over the past few decades, formed science clubs and held camps for school children to promote science. The Ernakulam District Total Literacy campaign was carried out by around 800,000 volunteers and 400,000 instructors (Tornquist and Tharakan 1995: 57) who were closely involved with the KSSP. Although it is closely affiliated to the CPM, the KSSP is formally an autonomous organization, and depends on individual contributions from its members and profits from the sale of books and pamphlets. The KSSP has also been responsible for a strong campaign for environmental literacy, at times taking on the CPM's more traditional leadership. This activism has been a critical intervention into what might otherwise have been a more lackadaisical top-down approach. But what 


\section{Insurgent and electoral logics}

makes this possible is the fact that the government and its bureaucracy have publicized and legitimized these campaigns. Undoubtedly, the more the state takes over the management and implementation of these projects, the less likely it is that the movementist impulse will lead the campaign, and that the state will retain its politicizing thrust. This is certainly the more recent appraisal of the leftled literacy campaigns of the 1990s by Tornquist and Tharakan (1995). Moreover, as they note, the Congress-led governments have tended to undermine the programmes initiated by the left, although this has not affected Kerala's lead among other states in literacy rates yet. Nevertheless, this also raises the issue of whether the instability of left rule is a serious disadvantage at a time when it is attempting to renew a hegemonic project.

How does the progress of literacy in Bengal compare with that in Kerala? Undoubtedly, Bengal was in a far worse position compared with Kerala at the onset of independence and the immediate decades after. The legacy of princely state policies in Kerala most certainly determined this gap (see Table 6.2). However, all of the gap cannot be explained by prior state legacies. For example, between 1971 and 1981 Bengal dropped from sixth to ninth place among the Indian states in literacy rates, that is, similar growth in literacy rates was occurring in other parts of India (Mallick 1993: 87). In Bengal, currently only 24.37 per cent of the lowest castes, also known as scheduled castes (SCs), are literate (ibid.), while in Kerala nearly 70 per cent of SCs are literate (Census of 1991, Kerala). Amartya Sen recently argued, on the basis of a study launched by the Pratichi Trust (an institute founded by Sen), that primary school education in Bengal is deeply 'class biased' because of teacher absenteeism in SC and ST (scheduled tribe) schools - often reaching 75 per cent compared with roughly 33 per cent in other schools on average. ${ }^{6}$ Class bias, one might add, is the effect rather than cause of an education policy that lacks the energy of an insurgent and activist approach to solving the problem. This lackadaisical approach towards educational policy is in sharp contrast to the land reforms, for example - and speaks to the central thesis of this book that equality enhancing policies are most likely in areas where there is ongoing pressure by an insurgent associationalism. The absence in Bengal of voluntary and politicized organizations, such as the KSSP in Kerala, keeps areas such as education on a backburner - there is no direct politicization of literacy as an issue either from below, or from the party or

Table 6.2 Percentage of literates to total population: Kerala and Bengal, 1901-91

\begin{tabular}{lcccccccccc}
\hline State & 1901 & 1911 & 1921 & 1931 & 1941 & 1951 & 1961 & 1971 & 1981 & 1991 \\
\hline Kerala $^{1}$ & 14 & - & 28 & - & - & 41 & 47 & 60 & 69 & 95 \\
Bengal $^{2}$ & 9.40 & 10.41 & 12.04 & 12.25 & 20.02 & 23.99 & 29.3 & - & - & 57.7 \\
\hline
\end{tabular}

1 Figures for Kerala from Tharakan (1990).

2 Figures until 1961 from Statistical Abstract, West Bengal, 1962.

Figure for 1991 from Dreze and Sen 1996. 
the state. In Kerala, literacy was pushed from the princely state's response to missionaries, as well as from below by lower caste groups seeking mobility and gradually adopting it as a tool for politicization.

\section{Public health}

State inactivism regarding health care in Bengal dates back to the British era. During the late nineteenth century, poor drainage, sewage and hospital provisions resulted in the waves of cholera, smallpox and plague epidemics, among others, that resulted in high mortality rates. Rural dispensaries, in particular, lacked the necessary funds or provisions to check these epidemics (Sinha 1998). The high demand for labour in the jute mills, railway construction and a few cotton mills, unlike that in the plantations and commercial estates of Kerala, created large concentrations of labourers living in cramped, unhygienic conditions. The expenditure for sanitary works in Bengal remained below 10 per cent of the total expenditure during the 1890s (ibid.: 81). Bengal clearly did not inherit the infrastructure, or results of policy activism in the area of public health that Kerala did.

The difference between Kerala and Bengal in health expenditures in the postindependence era has not been large (Nag 1983). In 1975-76 per capita government expenditures on medical care and public health in Kerala was 14 per cent, whereas in Bengal it was 12.3 per cent. Two other factors appear to explain the differences in health-related indicators in the two states. First, the extensive spread of health centers in rural Kerala; in contrast in Bengal, by the 1970s, close to 30 per cent of primary health centres had not met their quota of two doctors per centre (ibid.: 22). The relatively poorer availability of health centres accounts for the much lower use of medical care facilities in Bengal (ibid.: 25). Infant mortality rates between the two states during 1992-93 show that in West Bengal the figure of 58 per cent is lower than that of many states, but in Kerala it is about 17 per cent (VHAI 1997). Another key factor explaining the differential rates of morbidity (i.e. the rate at which people report illnesses) is literacy and a general awareness of scientific and causal explanations for diseases (Caldwell 1986; Dreze and Sen 1996; Nag 1983). Undoubtedly, in Kerala, as literacy has had feedback effects on other social indicators, at a minimum it encourages an activist stance towards using institutions and demanding accountability. However, as we will see below, high literacy rates correspond with high unemployment and stagnant growth in Kerala, and point towards the uneven state capacities that were generated historically, and patterns that were not broken by left rule.

\section{Decline and crisis: the historical roots of different state capacities}

After two decades of unrestrained and almost mythic praise for Kerala, observers have begun to discuss the problems of the so-called 'Kerala Model', suggesting 
that redistribution is not the holy grail of development after all. The economic crisis that has gripped Kerala since the 1980s is all too real, a factor that has been admitted by leaders within the CPM. The state exchequer was simply unable to support the large welfare expenditure and costs, with economic growth at abysmal levels during the 1980s. Thus revenue expenditure was 14.5 per cent higher than revenue receipts, leading to a large outlay of funds merely to meet the revenue deficit (George 1998). Cash crops such as rubber and coconut experienced a sharp fall in prices during the 1990s which led to a new phase of stagnation in the second half of the decade. Labour displaced from this agricultural crisis could not be absorbed into the small industry sector

States such as Tamil Nadu began to supersede Kerala's social development because of high investment in the social sector, while doubts were emerging as to whether Kerala could continue its welfare commitments to social security, health and education. In some important ways, Tamil Nadu appears to contradict the thesis of this book, that is, social movements are an important factor pushing state capacity towards development. Movements among the lower castes and workers are quite weak compared with those in Kerala; its successive regimes have been marked by a populist regional nationalism in an environment of corruption and personal aggrandizement among its leaders. This stands in marked contrast to Kerala's left-wing trajectory. Tamil Nadu's investments in health care and education have not been adequately studied. Politically, Tamil Nadu has not progressed towards high substantive democracy.

The causes of the limitations of Kerala's developmental strategy are historically determined to some extent. As Mathew (from B.A. Prakash) notes, the industrial policy of the Travancore state was implemented during periods of famine and crisis in the post-Depression era, signifying a state commitment towards industrialization. However, this industrial policy virtually came to a standstill after 1947; practically all the energies of the communist and successive governments were aimed at the agrarian sector through land reforms and wage entitlements for agricultural labour. In addition, worker militancy and communist commitments to high minimum wage levels rolled back the highly exploitative and dependent character of the earlier industrialization under colonialism. Structurally, a weak bourgeoisie meant that Kerala did not develop an industrial growth model of its own, and it is unclear if it will ever follow this well-trodden path of third world development. Undoubtedly, unlike in Bengal, the industrial sector constituted a much smaller part of the economy compared with the agrarian sector. Yet low productivity and low capital formation plague Kerala's industries. It is not clear that labour radicalization is entirely to blame for this. Undoubtedly, foreign and domestic investors shy away from areas with high levels of labour radicalism, but at different parts of the economic cycle, particularly during the 1990s, Kerala showed a distinct improvement in both industrial and agrarian growth, possibly following the left government's attempts to de-bureaucratize economic planning through democratic decentralization. (For 
a full account of the recent, widely publicized and watched experiments with democratic decentralization in Kerala, see Isaac and Franke 2000.) A question for the future remains whether a successful development strategy can avoid the industrial phase and generate employment and productivity on the basis of knowledge skills and technical expertise. Indeed, the agrarian sector alone is insufficient to generate either sufficient employment or income. It is dominated by commercial crop production, a clear reflection of the economic base that was constituted in Kerala during the colonial era. Crops such as rubber, coffee, tea, pepper, cardamom, cashew, and coir and coir products continue to be the mainstay of agriculture at the expense of food crops such as rice and tapioca which Kerala has imported at least since the 1940s. Growers of such crops have always been at the mercy of international markets; global deregulation is reducing the competitive edge that Kerala once possessed (Jeromi 2004: 1584).

In contrast, the response to crisis in Kerala has been decentralized development, also known as the People's Plan. Since 1997 this attempt to garner small savings and voluntary labour, using input by local citizen councils as to development priorities, has been widely praised by observers. A growing literature has documented the plan in methodical detail (see particularly Isaac and Franke 2000). However, the critical issue underlying this plan is the attempt to avoid a technocratic and alienated approach to development, instead involving women, lower caste and agricultural labour in decision-making about resource inputs, training, tackling unemployment, providing micro-credit, and so forth. This also relies on an ongoing tradition of voluntary associations and labour, which this book identifies as dating back to the 1940s at least. This attempt at a renewed hegemonic project risks being stalled, however, by the ongoing instability of Left Front governments in Kerala where, compared with Bengal, the opposition of the Congress Party and its allies simply undermines any efforts at implementing a new policy regime. This renders the future of Kerala's experiments with democratic decentralization and people's democracy quite uncertain.

While Kerala's successes are clear, its problems are symptomatic of those faced by progressive movements everywhere, and in particular the developmental impasse that has gripped the third world. In view of this historical narrative and discussion of its contemporary problems, it is difficult to speak of a 'model' that can be emulated. But a clear lesson that emerges from this discussion is the fact that state strategies that invest in social development as a result of political pressure from organized social movements or insurgent episodes are more likely to lay the basis for a democratic pathway to development, than they are in the absence of such conditions. The task at the same time, given Kerala's own experience, is to trace the crisis in modes of post-colonial state formation and patterns of political mobilization and rule by the left, so as to understand why state capacity to induce industrial growth and cut expenditure on bloated bureaucracies has been weaker than its ability to deliver critical reforms in the social sector and raise standards of living through direct entitlements. 
It is now clear that the policy priorities of the Kerala left governments reflected the interests of its base; but since it has not been the only party in power it is important to ask about the Congress-led governments which alternated for considerable periods of time with those of the left. Peter Evans (1995) argues that the state ${ }^{7}$ in Kerala was 'embedded' far too much among the working classes of Kerala, and did not possess sufficient autonomy to make politically difficult decisions in order to drive accumulation. But neither answer is sufficient; embeddedness derived from democratic political struggles allowed the state to promote a full-fledged welfare state of the like not seen in most of the third world. This, coupled with the strong pro-labour policies of the left, often cost it politically, by creating strong counter-movements among farmers, sections of the middle classes, and the entrepreneurial classes. The answer lies in the weak political capacity of left parties to shrink the bureaucracy, that is, the weakness of its anti-bureaucratic struggles, coupled with the historically derived situation of bourgeois state formation without a bourgeoisie. Neither the CPM nor the Congress Party could easily create such a class. The new experiments with democratic decentralization appear to be aimed at reducing the power of the bureaucracy with community-based development but it is too early yet to evaluate its results. What is clear is that a development strategy that focused upon centralized state penetration of society and capacity building of the state, is now turning to non-state associations and organizations to provide the impetus for planning and development. The role of civic associations in pushing for development has a long-standing history, but as this book has made clear, these associations have had an intimate relationship with state formation. If a reversal is occurring in the context of wider global changes, and internal economic crises, as well as the fragile hegemony of the left, it is quite momentous.

\section{Conclusion}

Ironically, having decided that revolutionary insurrection was no longer viable, a combination of mass agitations and electoral competition became the only path available to the communists towards party-building and political power in India. The two tactics - one extra-parliamentary, the other parliamentary - often came into conflict, and this was not always because of the need to win elections. As we have seen, in Bengal, electoral competition from the Congress Party had successively been weakened. But initially, being the weaker and less hegemonic party of the two, the CPM faced a dilemma, namely, if its efforts were to be directed towards winning elections, would it have to make choices about alliances and direct its efforts towards matters that were a far cry from the reforms that constituted the path towards socialism? In showing the different paths followed by the two parties, I have argued that the Kerala CPM was in a much stronger position, as the more hegemonic party of the two, to define the terms of a public policy agenda, in a manner that was enduring for at least four decades. In Bengal, the communist party was a more 'autonomous formation', that is, as Kohli (1989) 
describes it, the party had gained a large degree of autonomy from the landed classes. But what emerges from a comparison with its counterpart in Kerala, is that it also developed as a party more autonomous from, or more disconnected from, the poorer and deprived sections of the population, as well as from affiliated or autonomous movements among the low caste poor, than in Kerala (again, this is an inherently comparative observation, for the Bengal CPM is less autonomous from the poor than, say, the Congress Party in Bihar). The argument is not simply about the intentions of the communists, or their inherent conservatism, but rather about strategic tendencies within the party that in part derive from its ties in civil society. Forged less as a movement than a party, the Bengal communists emerged as a powerful formation, in no small part because of the absence of a concerted and well-organized opposition from other parties. This factor, along with a record of stability and crucial land reforms have given the Bengal communists the mandate to stay in power for an unprecedented twentyfive years at the time of writing. Although this dominance has allowed them to wield considerable authority, and potentially create a radical policy agenda, Bengal does not have the social policy regime that Kerala does. These differences between the two parties reflect the different conditions under which the two parties have attempted hegemonic projects, differences in leadership and in the structural conditions which have also constrained them. The result is a paradox in which party dominance has attenuated the political will and ability to effect social transformations through the combined push of mass movements, insurgency and policies as instruments of change. 


\section{Afterword}

This book shows that the ability of the communists in Kerala (as Congress Socialists) to utilize existing political opportunities within the anti-colonial nationalist movement, to forge the beginnings of a hegemonic project that drew together several classes and a 'moral-political' bloc that could challenge the strategy of the mainstream Congress Party, was a crucial determinant of their ability to press for further democratization within the formal democratic context of post-colonial India. The insurgent push that the first ministry in 1957 attempted, then partially abandoned, had roots in prior political struggles that allowed them to use elections to further their ongoing attempts to organize, mobilize and attempt policy reforms favouring lower caste agricultural labourers, tenants and industrial workers. Undoubtedly, high levels of proletarianization formed the 'structural' context of political radicalization for all parties, but since we have reviewed comparative evidence that reveals similar conditions in other regions of India we must conclude that the specific forms of politics developed by the Congress Socialists were relatively autonomous from these underlying structures. Most importantly, the slower pace of radicalization by their Bengal counterparts, combined with a different set of origins in violent sects, made the communist party a lot weaker at the onset of independence, both organizationally and hegemonically in West Bengal. In this sense the Bengal communists lagged behind their Keralan counterparts, attempting a radical agenda and the building of a wider base almost entirely within the context of the formal democratic 'rules of the game'. This made electoral considerations paramount for a party that had begun in an organizationally weak position. In both parties this new context of inter-party competition (most crucially confronting the Congress Party) and an increasingly mobilized opposition in Kerala, resulted in muting aims of the communists; yet in Kerala widespread policies to offer direct and indirect entitlements in the form of social security, education, nutritional programmes, as well as land tenure reforms and minimum wage policies, had already been put in place. These interlocked policies have been difficult for any subsequent Kerala government to roll back. The institutionalization of the communists and their affiliated movements and organizations in Kerala has created a 'policy regime' that exists regardless of whether the Congress or CPM holds power, although 
fierce competition and ideological differences between the two parties certainly do threaten policies implemented by the other. In Kerala, policy legacies over the twentieth century have also rendered the state's role in promoting welfare a crucial part of any democratization project.

Not surprisingly, such reforms, while under increasing criticism in Kerala, have continued to grow since the 1980s. New projects for democratic decentralization are not premised on the rolling back of welfare, but on creating the conditions for making them more affordable, that is, to roll back the economic crisis rather than anti-poverty programmes. It thus seems misplaced to focus on the communists as the harbingers of crisis. Rather, conscious reinvention of the democratic principle of reform is embedded in the party's approach to development in the region. Counterfactually, the set of possibilities for avoiding the economic crisis cannot be merely construed in economic terms, but must grapple with whether these possibilities could realistically subvert the democratic principle.

The consistent presence of the state in Kerala's development policy continues colonial policy legacies developed in the region, filtered of course through indirect colonial and princely rule in the provinces of Travancore and Cochin. The communists adopted the language of 'upliftment' and enlightenment and transformed it into a new language that converged with class struggle. But in controlling the state, particularly in the early years of independence, they defined the state as an instrument of development in welfarist terms (achieving widely acclaimed results) but not as one dedicated to developing the productive forces.

At the time of writing the bulk of this book, the CPM in Kerala was out of power, but in the 2004 parliamentary elections it once again swept to victory. Its repeated movement in and out of state power has been the result of a number of factors among which the two most important are the ongoing economic crisis, and the rise of a more vociferous rightist opposition. Esping-Andersen has observed that all policy regimes have distinct beginning, middle and end points (1990). New conditions, either external or social structural, call for new party strategies and tactics to ensure democratically derived hegemony. One of these changed conditions is the decline in ideologies of statist development, and the rise of neoliberalism. In Kerala, the discussion has revolved around how to avoid the ravages of a pure market-led strategy of growth, yet find solutions to the problems of slow growth, high unemployment and declining state coffers. 'Democratic decentralization' has been one such answer. In practice, it draws upon a vast volunteer network and the devolution of authority to local councils (panchayats) with the idea that it can lead not only to more democratic developmental outcomes, but also to the more efficient allocation of resources.

This strategy is vastly different from the class confrontations that characterized the communists' first foray into parliamentary politics. Recognizing that the electoral support for the CPM and the Congress-led coalitions roughly equal each other, the CPM is now attempting a more 'conciliatory' approach towards questions of class struggle and inter-party struggle. This strategy has 
evolved over successive declines in party support, and the fragility of the coalitions during the 1981 and 1987 ministries (Isaac and Franke 2000). Heller (1999) has extensively discussed the changes that brought about a "class compromise' between labour and capital in Kerala. Among these changes are the reduction of class confrontation, strikes and agitations among workers in the lowprofit, technologically stagnant industries such as coir, and an agreement with representatives of factory owners, management and industry agencies to introduce intermediate technologies that would not dramatically displace labour in the context of a high unemployment rate. What concerns us here is the fact that any such economic project is simultaneously political - and it will necessarily draw upon the legacy through which the left has derived its hegemonic capacity. Or, put another way, the organizational legacy of the penetration of the left in civil society will in all likelihood inform its future strategy of gaining hegemony. This includes the high emphasis being placed upon 'deliberative democracy', that draws upon (and contributes to) innovations in development theory, which emphasize that democracy and growth are not zero-sum but, rather, potentially positive-sum relationships.

This book has attempted to place political strategies and tactics, or what I have called political practices, at the centre of a theory of democratic social policy regimes. Rather than simply assert or refute the importance of state forms, or the potential autonomy of the state, I have shown that without accounting for the mode of ascendancy of hegemonic parties, and their structurally relevant political practices, we cannot explain the timing or content of such policies. In ascertaining the importance of political practices, the book has been in large part a methodological exercise - seeking to extricate from the welter of historical detail the extent to which what the communists and their predecessors did actually mattered. The use of counterfactuals was a particularly crucial part of the method in ascertaining the turning points at which communist ascendancy might not have happened during the years of ferment in the late nationalist years.

The primary argument has been that the political practices of the Congress Socialist Party in Kerala during the 1930s and 1940s had the effect of winning the party (and the future communist party in the region) political hegemony, and workers and poor tenants political power in the future post-colonial state. The CSP thus laid the basis for the first major electoral victory of a communist party (except for the PCI's (Partita Communista Italiano) victory in the San Marino principality of Italy). A classic case of dependent underdevelopment, Kerala's hitherto disempowered tenants and workers were represented first by a left socialist party (the CSP), and later by a communist party (the CPI) which was to hold state power intermittently for the next four decades and enact substantial anti-poverty reforms.

What were these political practices, and why did they work? Congress Socialists continually transformed ongoing political struggles, pushing them at the boundaries, and redefining them to strike at the core of state-class relations. The early strategy of the Congress Socialists was not a classic communist 
strategy of proletarian organization or peasant guerilla war; rather, beginning first as social reformers within their own castes, the upper caste Congressmen gradually struggled for civil rights for the lower castes. Yet in the aftermath of the Depression of the early 1930s, in the context of growing landlord oppression, proletarianization and unemployment, the Congress Socialists brought new theories and strategies to the political arena. Apart from conducting specific actions around sites of production, such as strikes in factories or demonstrations and boycotts at landlords' estates, they also fought against the state institutions (monarchical and colonial) that buttressed the forms of production. Moreover, the Congress Socialists utilized the crucial niche provided by the Congress Party at this particular historical moment, working from within it instead of outside it (as did the CPI). This gave the CSP legality and legitimacy vis-à-vis various political actors and, more importantly, the British administration, thus allowing the party to employ mass mobilizing tactics that gained it rapid popularity. While Congress Socialists elsewhere - in Bihar, Andhra Pradesh, the United Provinces - also attempted to 'transform the Congress' from within, they were less successful. This is because the political organization of the dominant classes, as much as of those below them, affected the particular form that nationalism (and the Congress Party) took in the three regions of Kerala. Thus despite the ongoing domination of landlords and 'upper' tenants, their failure to organize themselves politically within the Congress Party in Kerala provided a crucial opening for the CSP. For the CSP could not only wage a struggle at the ideological and political levels (as in, for example, the question of Gandhian vs. non-Gandhian methods and tactics), but they were also able to win these intra-Congress battles (by becoming the stronger faction, and by winning KPCC elections and leadership of the Congress Party for brief periods). This was because they also represented the class organization of the workers and tenants in the three regions of Kerala.

The outcome of the political hegemony of the CSP in Kerala cannot be attributed in an unmediated fashion to 'objective conditions' such as caste-class relations, or the high degree of proletarianization that occurred in the three regions that constituted it during the colonial era. Although the emergence of a class structure with a large proletariat possessing strong rural links created a high potential for class-based organization and mobilization, party tactics were crucial in transforming this potential into concrete outcomes. In Malabar, caste relations had hitherto exercised a largely conservative influence upon peasants; so here the practices of the CSP were crucial because they aimed at overturning centuries of deference and submission to the upper castes in the very process of organizing tenants against landlords. Similarly, Ezhava workers in Travancore were largely organized by their caste association, the SNDP, whose largely middle class leadership remained preoccupied with cultural politics. The CSP successfully superseded the influence of caste associations on the poorer and working class members of the lower castes. Thus, although colonial rule created an uneven potential for radicalism, in the absence of the specific political practices of the 
CSP this potential may never have moved beyond what Max Weber characterized as 'intermittent and irrational forms of association'.

The argument being made here differs from the thrust of many recent attacks on structuralist explanations by virtue of the fact that in seeking a substantive theory of communist ascendancy and rule in Kerala (and the relative failures elsewhere) it takes the correlational findings of a prior generation of scholars seriously. Thus this theory has been based on examining how the prevailing patterning of social relations in colonial and post-colonial Kerala made some political practices more likely than others, or made it more likely that leaders and organizers would adopt one set of practices over others (non-violent vs. violent tactics for example). The argument sought to place the process of party formation within larger structural transformations occurring in Kerala, including patterns of state formation that were taking shape in the princely states. More generally, the substantive theory developed in this book has generated the elements of a research programme that moves beyond the somewhat tired formulation of how 'structure' and 'agency' 'interact' towards a more concrete theory of how the very workings of structures generate the potential for change, for crisis, rupture and transformation. Thus, rather than maintain the rather unhelpful abstract duality of structure and agency, the theory advanced in this book has utilized a more innovative theoretical approach for the study of social and political movements that recognizes that the manner of their interpenetration is itself contextually and historically determined - at times the most intense efforts of 'agents' can lead to very little structural transformation.

The focus on a single case (that of Kerala) has at the same time sought to avoid its potential arbitrariness by simultaneously utilizing insights and knowledge gained from broader correlational studies, and a range of comparative cases. Indeed, what develops both methodologically as well as theoretically is a substantive theory that links quite easily with 'general' theories, or provisional generalizations, correcting, modifying or rejecting them as the case may be. My substantive theory, first, contributes towards a 'general' theory of class formation and politics in colonial contexts where (1) the social formations are not fully capitalist, and (2) the colonial state organizes and shapes categories in 'civil society', such as caste and class. Most colonial social formations are partially capitalist where two forms of surplus extraction co-exist - extra-economic and economic. Thus even when the peasant sells his/her entire produce on the market and pays cash rents, he/she is often tied to the landlord through patron-client linkages, and forced to lean on him during times of distress. As the case of Bengal shows, furthermore, such ties can be reinforced when peasants and landlords belong to the same caste. In Bengal, rich peasants or jotedars used their caste identity to mobilize peasants against colonial state taxes, despite the existence of clear class antagonisms between the two classes. A hypothesis that can be derived from this specific case is that when there are high levels of peasant differentiation, and a substantial anti-colonial interest, for example against burdensome state taxes, the emergence of class conflict is less likely. This is 
because anti-tax rebellions against colonial states are a necessary and integral part of any anti-colonial movement, and nationalist parties are less likely to risk putting the success of such campaigns in jeopardy. Support for this hypothesis comes within India from the neighbouring regions of Madras where class has not been a particularly strong axis of conflict. Moreover, when 'extra-economic' ties of caste or kinship reinforce the paternalistic ties of landlords and tenants, class conflict is unlikely to emerge unless this tie is disrupted (by internal or external factors) and politicized as a 'class' issue. This of course would suggest that in most parts of Asia and Africa, the hegemony of class-based parties and organizations (if not their emergence) has been constrained by the nexus of colonial rule and underlying social structures. Indeed, as James Scott (1976) noted, peasant rebellions have been far less frequent than might be expected in colonial societies; in fact, they are more remarkable for their absence than occurrence. Yet the development of peasant rebellion in one place and not in others, even when underlying conditions are fairly similar, suggests that we need to examine more clearly how the strategies of representative parties and organizations, and leaders, and the emerging political practices have played in the creation, success and failures of movements.

The second obvious question that emerges is whether anti-colonial nationalism and working class and peasant rebellions/radicalism have been inherently at odds. Clearly, this is not the case if we look at the case of Vietnam, where Ho Chi Minh's strategy was precisely to utilize rather than shun the anti-colonial movement in the service of a revolution. Nor is this the case if we consider the vast evidence of peasant and worker radicalism that developed, even if at the fringes of anti-colonial movements. The issue is more specific - how did anticolonial nationalism prevent the sustained growth and institutionalization of peasant and worker movements and parties, indeed, in the language utilized in this book, the hegemony of these movements? This question takes us to the question posed in Chapter 3 of this book, namely, why in Kerala did anti-colonial nationalism and communist party growth occur in tandem, as inherent parts of one another? In Vietnam, the strategy of the communist party under Minh's leadership succeeded in creating a popular front with middle class elements drawn to the party's more moderated goals. By slowly taking advantage of opportunities opened up by the easing of French colonial repression, the communists used their semi-legal status to capture the nationalist movement (Duiker 1981). Likewise, the 'liberal' aspect of British colonial rule in India, as one side of the coin (the other side being the undoubted damage wrought by the extraction of crucial resources, commercial penetration and political repression), allowed for the gradual transfer of power to the Congress Party, tolerance of its methods, and concessions and reforms around which the Congress Party could easily mobilize. In turn, the Congress policy of allowing internal factions created a niche for a party like the CSP, which could operate within, but in opposition to, the Congress Party. Thus the crucial general and comparative question is, how does the political form of colonialism (that is, liberal, authoritarian, repressive) 
affect the set of possibilities available to anti-colonial political actors to pursue their strategies? It would appear that the more 'liberal' the colonial regime, that is, the more its form of rule relies on a balance of legitimacy and coercion, the more likely the chances that a mass-based nationalist movement would emerge. Large, mass-based movements are difficult to forge underground, and they require a range of tactics that the middle classes are more likely to adopt when the consequences are likely not to be too dire - thus civil disobedience, boycotts, pickets and peaceful non-cooperation were astutely used by Gandhi to forge a mass movement in India. The more repressive colonial regimes, based upon the extraction of resources and labour through sheer force, achieved their stability precisely through stifling political dissent. When nationalist movements emerged through underground resistance, they had potentially more radical aims than the mainstream anti-colonial movements; however, fighting for their very existence, they failed to carry through a broader mobilization project, or in the long term any project of transformation.

The ironic lesson of the Indian nationalist movement, however, is that the broader the coalition of anti-colonial forces, the more likely that class conflict will be submerged. In part this is because the political leaderships that emerged were less likely to be drawn from the subordinate classes or castes. If and when 'organic' leaders emerged from within these classes or strata, their leaders tended to forge 'autonomous' movements, that is, they tended not to identify too closely with modern political parties (movements such as the Mau Mau rebellion (a Kenyan uprising against British colonial officials, 1952-60), for instance, and the Moplah Revolts in Malabar are cases in point). The form of mass politics developed by Gandhi was based upon a strategy of 'struggle-compromisestruggle' against the British, with the rather strict prioritizing of the anti-colonial struggle over other social conflicts. Such carefully orchestrated movements such as the civil disobedience movement were premised on the containment of class tensions because they threatened the viability of a cross-class coalition, and because of the 'non-violent' tactics espoused by Gandhi who, apart from his moral considerations, rightly felt that violence would provoke repression rather than dialogue.

A major problem with the treatment of Gandhi's leadership in the historical literature is the failure to specify the conditions that made his rise possible, but also those conditions that made the hegemony of his leadership uneven. That Gandhi's leadership was not always hegemonic is a consequence of the uneven development and strength of Congress organization (as in Kerala), and the underlying 'objective conditions' as in Bengal, Kerala, Andhra Pradesh and Bihar, wherein class and caste tensions did not fold neatly into an amorphous cross-class movement. But what conditions were most likely to lead to a challenge to Gandhian tactics and the orientation of the nationalist movement?

To begin with it would appear that challenges to Gandhian tactics were likely to succeed only when the underlying 'objective conditions' were favourable to a leftist challenge, as in Kerala. In other words, undoubtedly, the presence of a clear 
class division within the agrarian structure, between landlords and tenants, with a weak class intervention from the upper tenantry within the nationalist movement, made it more likely, but not inevitable, that the Congress Party would be radicalized. What mattered necessarily was whether this potential was seized and how it was seized. We have seen this in the case of Bihar where despite underlying 'objective' conditions for challenges to the Congress Party's hegemony, the vacillating and fragmented left leadership was unable to seize the historical moment that was presented in general to the left during the 1930s and early 1940s. Skilful political practice, developed by testing 'theory' in the real circumstances obtaining at that particular historical moment in British India, were crucial in transforming the potential for class and caste struggle into class formation. This formulation stands opposed to the voluntaristic formulations of nationalist movement scholars such as Chandra (1986) and Joshi (1992), who suggest that a suppressed historical alternative lay in the possibility of left parties (CSP, CPI and other left actors) 'transforming' the Congress Party. As the comparison between Kerala and Bengal in Chapter 5 illustrates, however, the political formations, that is, the balance of political forces which in large part reflected the underlying 'objective conditions', all but closed off the possibility of the transformation of the Congress Party in Bengal (and in other regions). Such a 'transformation' was a more viable option in Kerala, where the dominant classes had abdicated a political class representation within the nationalist movement. Unlike, for example, in Bihar, the Kerala CSP did not face the stiff challenge posed by the dominant agrarian classes who were organized through the 'right' wing of the Congress Party. Whether or not the 'left' aborted the possibility of transforming the Congress Party can only be decided by examining the underlying class forces and processes of class formation in late colonial India. Undoubtedly, such an inquiry, based upon the theoretical model I have proposed here, would yield a vastly more complex picture of what was actually possible.

Finally, the question is, how did the political struggles that were both led by and constituted the Congress Socialist Party, and the effects of these struggles on the party's base, organizational strength and extent of political hegemony, enter into the process of determination of the communists' capacity to win elections and use state power to effectively put through anti-poverty and redistributive reforms? Here, I have tied together an emphasis on the early development of extra-parliamentary capacity within a wholly different set of conditions in Kerala, which made the 1957-59 tenure of the communists a particularly proactive one compared with the much later parliamentary tenures in West Bengal. The concept of extra-parliamentary capacity links together two distinct fields the study of social movements and the study of policy - by suggesting a focus on the non-state aspect of the political. In other words, it suggests that parties in particular congeal the form and content of struggles, and act as conduits of retranslated policy legacies. This also suggests another crucial linkage - that between the colonial and post-colonial eras, in which the new political rules of the game that were created at independence, the much-vaunted parliamentary 
trajectories? I would add that what follows are outlines of a research agenda that awaits future work.

\section{Social Democratic ascendancy and hegemony in Sweden}

Esping-Andersen (1985) has demonstrated the importance of party strategy and tactics in the creation of the class alliances that underpinned social democratic ascendancy in the Scandinavian countries. He shows that despite some differences, all three countries possessed fairly similar structural characteristics in the late twentieth century - a weakened nobility, a substantial proletariat, and a weak and divided bourgeoisie. Yet the ascendancy of the Swedish SAP (Sveriges Socialdemokratiska Arbetareparti) was the quickest and most enduring. EspingAndersen attributes this to the SAP's success in forging a farmer-worker alliance, and its ability to maintain a strong reformist agenda in government, that is, the 'class forming' effects of social policies. The hegemonic character of working class formation thus could not simply be read off from its 'structural presence', although the weakness and fragmentation of the bourgeois parties and the presence of a strong farmers' movement made some strategic choices possible, and not others.

Apart from illustrating their success in forming class alliances, a comparison between the British Labour Party and the Swedish SAP highlights the importance of party strategy and tactics in civil society. The British Labour Party's comparative weakness has resulted from its failure to make links with popular movements such as the labour, temperance and nonconformist movements; this also applies to the Swedish party (Pontusson 1988: 43). These movements intermingled and reinforced class formation in Sweden - thus the struggle for suffrage, as Pontusson argues, politicized union activities and produced a 'class unionism' (ibid.). Overlapping membership in unions and popular movements was quite common in Sweden. Apart from the fact that this party/movement nexus gave the Swedish Social Democrats popular legitimacy, this early experience helped shape their attitude towards coalition formation, the creative, strategic use of which was to underlie their long-term parliamentary success. The absence of such a party/movement nexus in Britain, caused by the failure of the British Labour Party to make strategic and tactical connections with popular movements, rendered its capacity to hold state power and effect transformation all the more difficult, that is, gave it a lower 'hegemonic disposition' (ibid.). Neither Esping-Anderson nor Pontusson, however, asks why these differences in strategy emerged between Sweden and Britain on the one hand, and the other Scandinavian countries on the other. More detailed investigation of the relationship between the class and social structures, prior forms of associationalism and party practices would reveal why the SAP emerged successful in comparison to the other parties. Likewise, the intra-class struggles, or struggles between parties and their factions, are not analytically developed in either substantive theory. Such a theory would elucidate in greater depth the 
democracy, also re-inscribed the field of the political by making electoral victories paramount to the survival and growth of parties. This has had crucial consequences for what left parties in India could attempt - given the underlying social structural conditions, the formal democratic rules of the game favoured the larger, centrist party, the Congress Party, which forced a strategy of forming coalitions upon the left. Between the two, the Kerala CPM had developed sufficient hegemonic capacity to mitigate the effects of coalitional politics, at least for a while, but in Bengal, the electoral and coalitional logic of mobilization prevailed over the insurgent. The CPM had to strike a balance between whipping up the radical and revolutionary potential of sharecroppers, agricultural labourers and workers while maintaining its political toehold in an environment of considerable violence perpetrated by its political enemies. Its dominance in successive decades since the 1970 s is testimony to its political skill in striking this balance, but this meant a relative neglect of the social policy domain. In other words, Bengal's left has succeeded in maintaining its popularity by enacting policies that benefit its social base, but that stop short of greater social transformation, in part because there are no great pressures on it to do so. Indeed, most of Kerala' social policy regime was instituted in the two decades between 1957 and 1977, during which the communists brought considerable pressure on the Congress-led coalitions to implement social policies beneficial to the poor. In contrast, the CPM in Bengal has combined a centrist policy of coalition-building (as has the Kerala CPM), with uninterrupted rule, both of which have made for a slow process of reform. Moreover, in Bengal, for historical reasons, the poorest agricultural labourers and peasants have not developed autonomous movements, and neither have these been a consistent part of communist party growth and development (barring the early radical years during the 1960s until the end of the Maoist insurgency).

This is a somewhat difficult and sobering lesson for left parties in general proximity to the state and closer identification with it tends to deflate the radical tendencies that enabled them to grow, while the greater the distance (inability to field successful candidates, electoral irrelevance, very short tenure in power), the more their position of near futility deepens as poverty and inequality continue to grow.

Two cases in vastly different contexts, namely, Scandinavian social democratic ascendancy, and the ascendancy of the PT (Partido Trabahadores) in Brazil allow us to examine possible parallels, differences and modifications to the main propositions developed in this book. While the Swedish SAP attained 'hegemonic' status since its initial ascendancy in the 1930s, the Brazilian workers' party or Partido Trabahadores (PT) had until recently experienced greater difficulty (at the time of writing, the PT won national elections for the first time in history). Differences in the larger political-institutional frameworks within which these parties have functioned notwithstanding, the question is, how well can a theory of the 'relative autonomy of parties' allow us to explain their 
actual relationships between underlying structures and party formation, allowing us to understand in more detail where political practices come from.

\section{Brazil's Partido Trabahadores}

The Partido Trabahadores (PT) in Brazil has attempted to balance its movementist character while establishing a strong presence in political institutions, by fighting local as well as national elections (Keck 1992). In seeking to explain its emergence as a strong contender on the Brazilian political scene, a 'cleavages' approach might point towards the rapid industrialization of the 1970s and 1980s, during which the size of the working population had attained a 'critical mass'. Yet a theory of the PT's own strategic choices and tactics of struggle within the new political opportunities that opened up during the democratization of the 1980s, is key to understanding why the PT has gained ascendancy, and why it may have had some difficulty in translating this ascendancy into a 'hegemonic disposition'. It bears mention at this point that Brazil's location in global capitalist markets makes political outcomes in the country of much larger concern to international and domestic financial capital, and keeps the range of choices open to left parties somewhat more restricted than those available to parties like the CPM (for whom domestic constraints are considerable, including the possibility of central government intervention).

As Keck (1992) argues in a comprehensive study of the PT, its strategic ambivalence, demonstrated by in-party bickering about the role of the party in promoting democracy and discomfort with its political identity as a movement other than governing party, has cost it support at critical moments. Thus, for example, the PT was unable to use the electoral victory of its mayoral candidate (in 1982 in the town of Diadema) as a 'showcase administration'. This contrasts sharply with the use of local administration in northern Kerala by the CPI during the early 1950s, which began the process by which it gradually assumed greater hegemony in the political sphere. The PT, Keck claims, has lacked preparation for municipal government, and faltered in offering a political 'vision'. On the other hand, the PT's movementist character, that is, its intervention in 'civil society' in the form of 'social movement unionism' has been key to its gains in credibility and a mass base.

In a number of respects, the PT's strategic ambivalence represents aspects of the party's situation within the political opportunities in ways that also serve it well. Thus, the leader Lula Da Silva's lack of connection with traditional unions and parties on the left became an asset - instead of coming to fear repression as many of his counterparts understandably had, he 'simply plowed ahead and said what he thought' (ibid.: 75). This offered a fresh (albeit unwitting) tactical advantage that galvanized and mobilized previously unmobilized workers. Here, the PT differs from the CPM in fundamental ways - it is not organized along Leninist principles of party organization, has a far more democratic internal 
structure, and unlike the CPM which had to carry legacies of national Politbureau and Comintern dictates, does not answer to an external authority.

During the 1970s and 1980s the labour movement (under PT leadership) expanded its horizons beyond the factory to make active links between the realms of 'production' and 'reproduction', including housing, transportation and the quality of urban life (Seidman 1994). Moreover, by linking itself to numerous popular movements, for example the landless rural workers' movement (Movimiento Sem Terra or MST), the PT expanded its reach beyond urban workers. These were the results of tactics forged by a self-consciously 'new' left. Future research could shed light on the reasons why and how PT tactics articulated with structural transformations, and how in turn the political practices of the PT have contributed to (or might in the future contribute to) structural transformations in Brazil. A counterfactual method of analysis would assess the extent to which the PT's own modes of organizing, its specific strategies and tactics, actually transformed the very terrain of struggle such that with each small victory new ones that were not open before became possible. Until now it appears that the PT's close relationship to the labour movement, and with the multiple and intersecting movements in Brazil that were aimed at democratization beyond the political sphere, allowed for its expansion in ways that a strategy aimed solely at electoral victory would not have. It has also given the 'working class' the status of a significant cleavage in Brazilian politics. It may be too early for the PT's recent electoral victory to lead to reforms, in part because it inherits a national economy considerably imbricated with global capital. The comparable areas of policy will concern education, social security, health care and land distribution in rural areas, as well as urban housing policies. How the PT negotiates its relationship with radical movements such as the MST, for example, will be of crucial interest.

The evidence from the CPM's ascendancy and rule in Kerala (and from that of the SAP in Sweden when compared to its counterparts in Scandinavia) appears to suggest that rather than party dominance being the crucial ingredient for policyled reforms, it would appear that a strong party/movement relationship (which under conditions of a well-organized opposition may not allow for consistent domination of government) is more likely to produce radical social policies that have the effect of transforming social relations. Such a strong party/movement relationship, that is, the coincidence rather than separation of the two, is produced under conditions where parties make explicit links with democratizing movements. Redistributive and equality engendering policies are more likely to be outcomes of these ties, rather than left party dominance in the sphere of formal parliamentary democracy. Perhaps the most crucial conclusion, given the emphasis placed upon politics, is that new forms of politics, aimed at increasing rather than decreasing direct democracy, will be necessary for the communist parties in both Kerala and Bengal to emerge from the limits that procedural democracy has placed upon their activities. These limitations are different in the 


\section{2}

two cases - but they suggest that whether it is the plateauing of electoral support or the close identification of the party with the state liberal, procedural democracy has rendered both parties politically dependent upon the algebra of elections. New strategies in the extra-parliamentary sphere will be crucial in determining their future relevance - especially so as Hindu chauvinism re-emerges from the depths of India's past.

The issue of a party's relationship to democratizing movements is particularly important when we turn to the question of gender relations in Kerala and Bengal. Feminist scholars have noted that left parties have tended to marginalize the question of gender equality and empowerment, preferring to view the emanicipation of women as a class issue. Indeed, by avoiding questions regarding the insecurity of women, whether economically or socially and domestically, party dominance or insurgency stalls the evolution of substantive democracy, and comes into inherent contradiction with it. Even where women face issues of weak class organization, for example, in the cashew industry where women workers predominate, it should be a matter of much concern to the left in Kerala that women workers are not actively included in union activities (Lindberg 2001). The result is that women's movements are searching for alternatives to the traditional left in seeking to meet their goals. The left's past legacy of non-dogmatic democratic practices, of seizing the democratizing potential of historical moments, is under risk of being diluted when women are left out. This is after all the crucial lesson of the substantive theory of left ascendancy in Kerala that has been outlined in this book.

In the end the question is a general one: what kind of a democracy will ensure the guarantee of rights to resources and land, the necessary public activism to provide schools, health care and employment for all the men and women who have been left out of the spoils of market-based growth? Can the 'traditional' left form the basis for the revitalization of a political project, which can recognize and utilize new political opportunities under the very different conditions from those it confronted several decades ago? Or, in the spirit of the times, must we sweep away the old to make way for the new? This book suggests that we cannot ask these questions outside history. 


\section{Notes}

\section{Old legacies, new protests: welfare and left rule in democratic India}

1 Amartya Sen's renowned contribution to the definition of development was one based on the expansion of 'freedoms' and 'capabilities'. 'Capabilities', according to Amartya Sen (1995: 10-11) are the 'range of options a person has in deciding what kind of life to lead', that is, they are the opportunities available to a person, 'the alternative combinations of functionings from which a person can choose' to lead 'valuable and valued lives'. In linking the concept of development to the expansion of 'capabilities', Sen's renowned contribution was to expand the concept of the 'means of development' to a range of policy instruments that are not restricted to the market such as food security, minimum or living wages, land reforms and housing, that offer entitlements more directly. His work also draws our attention to 'inequality and neglect' as the twin causes of poverty, rather than the traditional focus by neo-classical economists on prices and markets.

2 This question has gained intellectual ascendancy in recent years, perhaps not surprisingly, as former insurgent movements such as the ANC have become enmeshed in liberal democratic structures. The works of scholars such as Fung and Wright (2001, 2003) and Heller (2001), seek to understand how alternative structures of 'deep democracy' can be generated from within the liberal paradigm of politics to create localized 'real utopias'. This way of posing the question fails to ask whether liberal democracy is sustainable only when it limits demands for substantive democracy.

3 There is considerable disagreement on the meaning of the term 'development', and it tends to be deployed in often contradictory ways. In using a definition borrowed in part from Amartya Sen's theory of development as entitlements that allow certain basic 'functionings and capabilities', this book suggests the inherently political nature of how we define development.

4 The East Asian instances form a contrasting case of state action via the soft authoritarian state whose social movement suppression allowed it to carry out economic reforms of labour, land and financial policy. Undoubtedly, its economic successes surpass those of Kerala's; however, no social scientist today could argue that India's reforms could adopt the East Asian pathway. Although India's movements are relatively weak, the essence of coalition and party politics in India has always been populist, spurring more rather than less democratization. Under these circumstances, soft authoritarianism is likely to backfire.

5 For a selective sampling of the non-academic commentary on Kerala, see 'South India success story: small families the norm', New York Times, 6 March 1980; 'The enigma of Kerala', Utne Reader, March-April 1996, no. 74; 'Look, I can read', The Economist, 27 April 1991; 'Poor but prosperous: development and quality of life can't always be measured purely in economic terms', The Atlantic Monthly, September 


\section{Notes}

1998; 'Indian state cuts population without coercion', New York Times, 4 January 1994. For a sampling of the vast literature describing these policies, see Caldwell 1986; Franke and Chasin 1989, 1991a; Herring 1983, 1991; Jose 1984; Kumar 1984; Nag 1983; Panikkar and Soman 1984.

6 As one of India's twenty-eight states, Kerala exists as a distinct political entity within the federation of the Indian state. At the state level, as at the national level, parties compete in a parliamentary system. Executive powers are normally exercised by the cabinet of ministers, with the Chief Minister at the top. States have the power to legislate on agriculture, industry, education, health, economic policy and police functions, but are subject to central government intervention in matters relating to trade, industry, and economic and social planning, in addition, of course, to 'civil unrest'. Most state revenues come from the centre, a situation which often raises the thorny issue of discrimination when opposition parties hold power in the states. It is a bogey that has been repeatedly raised in the two communist party ruled states.

7 Amartya Sen (1981: 305) has calculated that in the case of Sri Lanka, another exemplary case of social development until the 1980 s, it would have taken 152 years to achieve the same longevity increases through market policies (assuming no growth), or fifty-eight years assuming that all the growth is transferred to direct efforts at increasing longevity. In the meantime, the loss of human life and poor quality of life enter the calculus of developmental failure immeasurably (see Sen 1990).

8 See the highly contentious debates in South Asia Bulletin 1998, 1999. Indeed, Kerala's economic problems are not merely illusory. Economic growth rates have been slower in Kerala than in many other parts of India, unemployment high, and agricultural and industrial productivity fairly stagnant. Between 1962-63 and 1974-75 Kerala's domestic product grew at a moderately healthy pace of 3.21 per cent, but between 1975-76 and 1985-86 this growth dropped to 1.76 per cent per annum, and to 1.34 per cent by 1991. The slowing down of population growth (a result of state policies such as better health care and education) prevented the economic growth rate from turning negative (George 1993: p. 6). Yet with only a 0.3 per cent growth in state GDP between 1980 and 1990, Kerala's infant mortality rate was the lowest in India at 17 per 1,000 compared with states like Tamil Nadu (58), Madhya Pradesh (111), and even West Bengal (66), all of which had growth rates during that period between 2.5 and 3.0 per cent (Dreze and Sen 1995: Table A3). Mortality rates, as Sen (1995) argues, tell us more than economic growth rates about how much de-commodification exists in a society.

9 The reforms granting sharecroppers titles to their land were written as early as 1950 and 1955 when the Congress Party had formed state governments, but the impetus for taking the reforms off paper actually came from the communists.

10 Ranajit Guha (Guha and Spivak 1988: 42), one of the founders of the group of radical historians called the Subaltern School has argued that:

the initiatives which originated from the domain of subaltern politics were not, on their part, powerful enough to develop the nationalist movement into a full-fledged struggle for national liberation ... the numerous peasant uprisings of the period, some of them massive in scope and rich in anti-colonial consciousness, waited in vain for a leadership to raise them above localism and generalize them into a nationwide anti-imperialist campaign.

Thus, rather than the weakness of radical impulse, it was the weakness of leadership that was held to explain the left's inability to gain political ascendancy. As Sumit Sarkar (1983: 338) writes: 
[t]he years 1935, and particularly 1936, saw the emergence of a pattern in Indian politics which would be repeated often, both before and after Independence. Outwardly, all the signs were of a significant lurch to the Left: growing Socialist and Communist activity (despite the 1934 ban on the CPI), numerous labour and peasant struggles, the formation of several Left-led all-India mass organizations. ... Yet in the end the Right within Congress was able to skillfully and effectively ride and utilize this storm

Bipin Chandra (1986: 21) also argues that 'although the left grew in numbers from 1936 to 1939 it failed to establish ideological hegemony over the national movement, that is, to effect a basic transformation of the Congress ideology'. Consequently, 'the left remained, and was to remain for decades after, a vent or a channel for popular grievances, the organizer of ... social protest ... but its political character was to remain that of a pressure group and not that of a leader of the masses contending for socio-political hegemony over society' (my emphasis).

11 Barrington Moore offers this hypothesis with a qualification:

$[C]$ aste, and the theory of reincarnation, which forms an important part of caste doctrines, has also been used to explain the apparent political docility of the Indian peasants, the feebleness of revolutionary upsurge in modern times. Yet, we have seen that this upsurge was an important component of the forces that brought down the Mughal edifice ... Still the overall evidence ... remains overwhelming'

(Moore 1966: 334-35; see also pp. 458-59)

12 There are many possible approaches to explaining Kerala and understanding its general significance. Existing approaches have been of two kinds - either to place Kerala in a broad comparative sweep that is generally not historically analysed, or to analyse it as a single case without drawing out its comparative implications in sustained fashion. Examples of the latter include the rich empirical studies and theoretical advances made in Herring (1983), Heller (1999), Kannan (1988), Panikkar (1989), Jeffrey (1976) and Nossiter (1982). In particular, Heller, Herring, Jeffrey and Kannan have provided detailed studies of the ascendancy and strategies of the communists, both with regard to land reforms, social security, anti-poverty measures, and the more recent democratic decentralization experiments. Where this study differs from its predecessors is in asking why Kerala became different from cases that shared similar conditions, that is, more specifically, what difference political practices deployed by the communists made to the construction of Kerala's distinctive pattern?

13 Bernstein 1961; Kautsky 1971; Lenin 1933. See also Esping-Andersen 1985; Miliband 1983; Poulantzas 1978.

14 This issue split the social democrats and communists, with the former accepting the possibilities for socialist transformation from within parliamentary capitalism (EspingAndersen 1990). While communists eschewed participation, socialists have held that the key struggle is to extend the democratic principle from the political to the social (or economic) realm (Przeworski and Sprague 1986).

15 Thus parties that seek to organize workers as a class cannot simultaneously address 'the people' or 'the nation' in search of broader coalitions, according to Przeworski, (1985: 103).

16 The relative paucity of cases where the practice and theory of leftist parliamentary activism have met makes the question all the more difficult to answer in general terms. Other than brief attempts by Allende in Chile, Italian communists in municipal government, and the Sandinistas in Nicaragua, few parties with the explicit objective of using parliamentary democracy to further a substantial redistributive agenda have held power. The only successful experiments that we have to date are the Scandinavian 
social democracies, and the communist governments of Kerala and West Bengal in India. Yet in recent years more and more formerly insurgent parties have attempted the electoral path - these include parties as diverse as the Partido Trabahadores in Brazil, FMLN (Farabunds Marti National Liberation) in El Salvador, the African National Congress in South Africa, even the Maoist guerillas in India (the Communist Party of India (Marxist-Leninist) - CPI-ML). The formidable constraints left parties face in gaining ascendancy and winning hegemony may give us some sense of the reason why the relationship between democracy (understood for the moment in purely liberal, formal terms) and left party ascendancy and reform have rarely appeared in history. These constraints are often structural, but they may also be strategic, that is, they have much to do with how structural possibilities are seized by parties at particular historical moments. Kerala is a rare example, whose defiance of the 'norm' may give us some clues about the weak links in this conundrum.

17 It can be added that although the book addresses parties centrally because of the particular circumstances of Kerala's achievements, the argument is a broader one about political practices employed by non-party actors as well. Indeed, in an era that decries the old practices of Stalinist and centrist left parties, the argument holds just as well for other decentralized non-party organizations even if their domain is not the formal sphere of parliamentary politics.

18 See Lipset and Rokkan (1967). Asking why 'did the working classes develop strong and unified political movements in some countries ... and deeply divided organizations in others', Lipset and Rokkan turn to 'national cleavage structures' generated by factors such as the medieval organization of a given country, size of polity, and position in the 'international interaction system' (1967: 96). Elsewhere they argue that the success of mass or working class parties depends on 'the size of work unit and the local ties of the workers, the level of prosperity and the stability of employment in the given industry' (ibid.: 21), as well as the church-state or urban-rural cleavages that develop in a given society (ibid: 132-34). Absent is a theory of how these 'cleavage' structures generated mass or working class parties.

19 A key instance is Paige's (1975) highly influential theory of agrarian revolutions, which gives virtually no causal role to political parties, arguing instead that the influence of radical or reformist parties reflects the underlying agrarian relations. For example, he argues that the communist vote in India and communist revolution in Vietnam were generated by 'decentralized sharecropping systems ... and irrigated rice production in particular ... [which] ... create a homogeneous landed peasantry with strong incentives for collective action and intense pressure for group solidarity' (Paige 1975: 62).

20 This argument touches upon the distinction often made between 'class structure' and 'class formation'. While 'classes' are 'empty slots'. 'class formation' is the activation of these positions by individuals who become collective actors (Esping-Andersen 1985; Przeworski 1985; Wright 1985).

21 The claim is not that parties form cleavages at their will, but rather that their formation as collective actors from disparate individuals sharing the same circumstances is contingent on how party-led political struggles shape the available structural possibilities.

22 This claim is closely related to theoretical efforts to understand the mutual imbrication and interaction of 'structure' and 'agency' as a central sociological puzzle (Giddens 1976; Sewell 1992). Thus, for example, as Sewell (1992) argues, capitalism not only generates particular classes, but it also generates the factory form, commodification, and differentiated forms of production that render it dynamic and unstable at one level, and profoundly stable at another. Sewell draws attention to the fact that capitalism has systemic properties that are invariable and stable at one level, yet its profound variation across contexts and instability is a product of labour and capitalist practices 
(agency). These forms of agency are, moreover shaped by both levels; to use Sewell's formulation, the 'transposition' of 'schemas and resources' inherent in these levels of capitalism give rise to agents' practices. In his words:

Structures ... are sets of mutually sustaining schemas and resources that empower and constrain social action and tend to be reproduced by that social action. But their reproduction is never automatic. Structures are at risk, at least to some extent, in all of the social encounters they shape - because structures are multiple and intersecting, because schemas are transposable, and because resources are polysemic and accumulate unpredictably. Placing the relationship between resources and cultural schemas at the center of a concept of structure makes it possible to show how social change, no less than social stasis, can be generated by the enactment of structures in social life'.

(Sewell 1992: 19)

23 The recent revival in theory and practice of the concept of 'civil society' draws upon a much older dichotomy in liberal theory, wherein civil society is understood as the realm that resists the encroachment of the state (Keane 1988). Drawing on James Coleman's theory of 'social capital', scholars are increasingly arguing that civic associationalism may build 'good government' by holding it accountable (Putnam 1993).

24 Esping-Andersen (1990: 34) recognizes this problem when he states that: '[D]ominance, to say nothing of hegemony, is obviously not a question of electoral returns; it must assume a capacity to shape policy making and, more generally, to structure society in accordance with a party's priorities'.

25 It is difficult to find a singular, coherent definition of hegemony in Gramsci's writings; in reference to the 'dictatorship of the proletariat' Gramsci's definition of 'hegemony' was not too far from Lenin's. It was elaborated, however, with the distinct purpose of separating a more organic concept from a repressive one: 'the key problem is not the physical personification of the function of command ... [it] ... consists in the nature of the relations which the leaders or leader have with the party of the working class, in the relations which exist between this party and the working class. Are these purely hierarchical, of a military type, or are they of a historical and organic nature?' (Gramsci 1971 (1921-26, p. 209), emphasis mine.

26 The theoretical interventions of Skocpol and others during the 1970s, in the form of the so-called 'potential autonomy of the state', sought to avoid reduction of the state to socio-economic determinants such as class, by emphasizing the policy legacies of states, 'state structures' and the activities of bureaucrats. In retrospect it is possible to see that Skocpol's well-placed critique of the functionalist variant of neo-Marxist scholars merely replaced one 'static structuralism' for another. Instead of the exigencies of capitalist accumulation, it became the organizational character of the state - the degree of centralization or structural location of bureaucrats - that was now responsible for particular kinds of social policies. As Skocpol and Pimenta put it: "[s]tates can be analyzed "architecturally", to find out how state building and state structures affect social policymaking through administrative and political processes' (1986: 149).

27 See Franke and Chasin 1991a and b. 'The Kerala Difference', letter to the New York Review of Books, (24 October), p. 72, and Amartya Sen's response in the same issue.

28 See for example Gopalankutty 1978, 1989a, 1989b, 1993; Karat 1977; Menon 1994; Kurup 1988; Namboodiripad 1943, 1957, 1959, 1968, 1976, 1984.

29 These variables interact to produce an outcome, which itself can be measured as a variable. The more the number of variables, and the greater the variation in them, the more robust is the theory, is the primary assumption. This is why quantitative analysis 
is most often the choice of method, for it has the benefit of increasing the variation in the putative 'variables', such that we can pose adequate tests for their causal value.

\section{The social bases of rule and rebellion: colonial Kerala and Bengal, 1792-1930}

1 Paige (1975: 10), for example, holds that rural class conflict can be understood as a function of the relationship 'of both cultivators and non-cultivators to the factors of agricultural production as indicated by their principal source of income'. He defines class as 'relations to property in land, buildings, machinery and standing crops and financial capital in the form of corporate assets, commodity balances, or agricultural credit' (ibid.).

2 This raises the question of whether peasants can be characterized as 'classes'. The term 'class' is a concept which applies to pre-capitalist social formations as much as to capitalist systems. However, because 'extra-economic' factors, rather than the market, characterize the means of surplus extraction, we need to avoid the tendency to superimpose models of action derived from capitalist contexts, in which a certain notion of 'instrumental rationality' applies. Peasants, of course, may engage in 'rational association', but this is not likely until the advent of modern parties and mass associations.

3 The vast literature on caste-class relationships is difficult to summarize or do justice to in brief (see Beteille 1969; Frankel and Rao 1989-90). For the moment it is sufficient to note that in colonial India (and to a much lesser but still significant extent in present-day post-independence India), class or property relations were concomitant with what Weber calls 'status groups', which in addition to controlling land and labour had an 'effective claim to social esteem in terms of positive or negative privileges' (1978, Vol. I: 305). Caste (as well as religion) can be understood as a 'status' form. The coincidence in places of 'class situation' and 'status' had important consequences for class formation and conflict, as I will argue, and risks being neglected when general theories of peasant rebellion are applied to the case of colonial India.

4 In the case of sharecropping, two factors - the decentralization of production and the need for irrigation - 'are likely to create a homogeneous landless peasantry with strong incentives for collective action and intense pressure for group solidarity. These economic characteristics should in turn lead to political radicalism, powerful organizations, and intense class solidarity' (Paige 1975: 62) (my emphasis). For a full elaboration of his theory, see pp. 58-66.

5 The decision to intervene directly in Malabar, and not rule indirectly through the Nair chieftains was prompted by the need to secure political stability in the region. In 1791 the British army under the Governor-General Warren Hastings had found itself in direct conflict with the Mysorean warriors Haider Ali and his son, Tipu Sultan, in a struggle to control the valuable trade in pepper and cardamom (Bayly 1988: 64). Haider Ali died in 1782, and by 1791 Tipu Sultan was narrowly defeated. This victory paved the way for British control over the region of Malabar. Thus Malabar was brought under the direct rule of the Bombay Presidency.

6 The first instance of the implementation of the zamindari system was the Permanent Settlement in Bengal in 1793. According to this policy the British identified revenue collectors from the Mughal era as proprietors of the soil. This policy granted them full ownership rights with the obligation of paying revenue to the colonial state.

7 Although the policy of granting landlords the ownership rights of landlords has been described as a mis-identification (which to some extent it may have been, given the welter of unfamiliar rights in land that confronted the British (on this see Guha 1996)), it was as much dictated by the British policy of pursuing expedient political alliances.

8 It is somewhat of a stretch to substitute the picture of the rack-rented, squeezed peasant cultivator, with that of the enterprising small cultivator who took to growing cash crops 
between 1921 and 1931 as does Menon (1994). He argues that 'seen in this light Malabar does not seem to be an anomaly within the larger south Indian economy, for which recent work suggests that the region should be seen as one characterized by independent market-oriented small farmers rather than of agrarian dependents under the sway of rural magnates' (Menon 1994: 22).

9 One author described it as follows:

The nature of the ... lease points to the fact that all land, including waste and forest, is said to be owned by someone, whether or not it has been cultivated. A man wishing to bring virgin soil under cultivation must therefore find out who the appropriate landlord is from whom he can lease by a kuzhikanam tenure. There is none of the freedom to cultivate unused land met with in other societies.

(Mayer 1952: 82)

10 Protection for Indian Coconut Industry: Criticisms Answered, AICC P-12/1937.

11 The relatively high proportions of agricultural labour to the agricultural population points to the status-based prohibition of manual labour for all except the lowest castes.

12 In 1904 the ratio of wetland cultivation to garden land was 53:100 in all of north Malabar, whereas in Ernad and Walluvanad, the two main sites of Moplah uprisings it was 203:100 (Wood 1982: 145).

13 For example, in one of the investigations conducted after the 1851 rebellion, relatives of the participants said that they had been taught that if a poor man was evicted from the land it was a 'religious merit' to kill the landlord (from the Report of T.L. Strange, 25 September 1852, MJ 483, 23 August 1853, cited in Wood 1987:137). It was reported that:

[T]he most perverted ideas on the doctrine of martyrdom, according to the Koran, universally prevail and are fostered among the lower classes of the Mappillas. The late inquiries have shown that there is a notion prevalent among the lower orders that, according to the Mussulman religion, the fact of a janmi or landlord having, IN DUE COURSE OF LAW, ejected from his lands a mortgagee or other substantial tenant, is a sufficient pretext to murder him, become sahid (or saint), and so ensure the pleasures of the Muhammedan paradise'

(Logan [1887] 1951: 616).

14 For example, an injunction given by a thangal called upon Moplahs not to use the honorific 'you' in addressing Nairs, and forbade Muslims from eating the remains of food prepared for richer Hindus during their festivities (Panikkar 1989: 62).

15 As Wood (1987: 88) notes, ' [b]y becoming a Moplah, a Cheruman labourer or Tien (Tiyya) verumpattomdar was recruited to a body which functioned as a self-defence organization of the rural subordinate whose ultimate weapon in this period was the outbreak', that is, the rebellion. This self-defence organization not only lacked the 'traditional basis of respect' for landlords, but it was made possible by the conversion of daily routines - rituals, the community organization of congregational prayers, common feasts and dinners - into mobilizing structures. Most importantly, in contrast to the scattered settlement of Hindu tenant-cultivators and poor peasants which inhibited collective action, the mosque provided a meeting point for Muslim peasants which leaders of the rebellions utilized as a site of radicalization and organization (Wood 1987: 40).

16 From Strange's Report to T. Pycroft, 25 September 1852, Correspondence Regarding the Relations of Landlord and Tenant in Malabar in 1852-56, p. 8, cited in Varghese 1970: 51. 
17 The following discussion of Andhra's land tenure system draws on Pavier (1981) and Kesava Iyengar (1931).

18 Governor-General Lord Wellesley instructed the first Resident Macaulay: 'the security of British interests in that quarter of India will not be complete until both the military defence of that territory shall be exclusively confided to the Company and its civil administration if not absolutely subjected to their control, at least swayed on all material points by their influence and counsels' (Lord Wellesley to Col. Macaulay, dated Fort William, 27 February 1800, cited in Yesudas 1977: 18).

19 The ryotwari system was a reaction to the failure of the Permanent Settlement caused by the depredations of the zamindars, and their continuing arrears of revenue payments. According to this policy, first implemented under John Munro, the Collector of the Madras Presidency, the cultivator or ryot would enter into a direct settlement with the colonial state.

20 The Resident-Dewan was more than a Resident; he appropriated the indigenous authority of the Dewan (the chief financial officer). The monarchy could not propose or initiate any measure without the Resident-Dewan's approval. Indeed, although the official policy of the Residency was to "carefully abstain from any open interference in the administration of the country ... with a view to the permanent interests of the alliance', the actual policy followed in Travancore was much the opposite. Officials of the state would visit the Resident twice a week 'to report extraordinaries, and to confer on public Business' (Fisher 1991: 214-5).

21 It is important to note, however, that these figures should be read as a broad sketch of the general social structural trends in British India, rather than as concrete and accurate measures. In part this is because of the discrepancies that necessarily arise in dealing with land tenure categories across such vast variation, and in attempting to pin down exact and comparable agrarian categories. Thus a better comparative picture would have to locate these discrepancies and attempt a more nuanced categorization.

\section{State formation and social movements: colonial Kerala and Bengal compared, 1865-1930}

1 Nicholas Dirks (1989: 45) argues that the British separated the political aspects of caste from its cultural and religious aspects, 'freezing' it as a tradition; however, in Kerala in particular the growing politicization of the poorer tenants and workers was intimately tied to political struggles over caste. These struggles were mediated by the British, either because of active lobbying by caste organizations, or through their own land tenure policies which empowered some castes at the expense of others.

2 Comaraoff and Comaroff (1991) note that LMS missionaries in Southern Tswana (South Africa) also largely drew the 'marginal, disempowered members of Tswana polities', who saw in Christianity a chance to overturn the hierarchies that they had lived with for so long. It was not among the chiefs, but among the 'serfs and clients' that the missionaries found their recruits. Indeed, their commitment to economic individualism, private property and the nuclear family was inimical to the chiefs of Tswana. There are strong analogies to the case of Kerala.

3 Kooiman (1989) notes that when the exemption from the poll tax was extended to Hindus, there was a sharp drop in the ranks of the missions (p. 73). Likewise, he characterizes the movement between Hinduism and Christianity during famines and epidemics as a 'kind of rush hour in an already existing religious boundary traffic' (p. 82).

4 Kooiman (1989) is careful to argue that the missionaries did not see themselves as the representatives of the poorest and most downtrodden, and often expressed much contempt for them (regarding them as 'superstitious drunkards' or having 'even less intelligence than the beasts of the field'). However, over time this attitude appears to 
have changed somewhat, and new missionaries appear to have oriented themselves towards changing degrading caste practices.

5 Toddy is a liquor tapped from the coconut tree. Toddy-tapping was a traditional occupation of the Ezhavas until the SNDP began to discourage it because it was considered degraded.

6 'Sanskritization' is a term coined by the sociologist M.N. Srinivas to describe the phenomenon whereby low castes emulate Brahminical customs in an attempt to rise within the caste hierarchy, that is, appropriate a higher caste status (Srinivas 1962).

\section{Political practices and left ascendancy in Kerala, 1920-47}

1 Omvedt (1976), for example, has traced how the Congress Party in Maharashtra actively sought the membership of non-Brahmins during the 1930s, after its more conservative leadership had rebuffed the non-Brahmins once during the 1880s. At the same time, Gandhi, who took a personal interest in the Congress's efforts in Maharashtra and caste politics in the region, distanced himself from overt signs of nonBrahmin radicalism. The non-Brahmin movement provided an avenue for the Congress Party to establish a base in Maharashtra; however, Omvedt argues that the Congress Party absorbed the insurgent quality of lower caste protest, and leaders of the latter movement began to search elsewhere for support. The Communist Party was a natural ally for many low caste activists, but this relationship was itself quite troubled (I raise this point later on).

2 Gandhi's own interest in the issue of untouchability and his willingness to raise it within the larger concern of anti-colonialism was undoubtedly a powerful impetus for social reform during the early 1930s. In Kerala, Gandhi 'blessed' a large campaign for throwing open temples to lower caste Hindus in 1931. The Guruvayoor Satyagraha, as the campaign was known, drew large crowds, and many of its participants were to later join the CSP and become communists. Among them, A.K. Gopalan and P. Krishna Pillai, were assaulted by the authorities, and the campaigners forcibly removed the barricades surrounding the temple. The Travancore state granted temple entry to all castes in 1936 in the form of the Temple Entry Proclamation. Gandhi's encouragement of caste protest, however, reached its limit when the tactics became more overtly confrontational.

3 Newspapers reported that Sri Narayana Guru had advised his disciples to walk along the prohibited roads, scale the police barricades and sit with others to dine in the temple. Gandhi, on the other hand, criticized his suggestion as rash, and the 'reverse of satyagraha', the method of truth and non-violence (Menon 1966: 125). In reply the Ezhava leader said that 'he was not a believer in non-violence in agitations for removing social disabilities and that ... he was anxious to secure for his community by any method, social equality ... with caste Hindus including temple entry and admission to caste Hindu houses' (quoted in Jeffrey 1978: 155).

4 National Archives of India (NAI), F/R, January 1936.

5 Now two forms of politics existed together, as illustrated in two reports on the same day in The Hindu. As SNDP leaders exhorted their members to renounce Hinduism and protested the use of the demeaning term 'chandala' in the Temple Entry Enquiry Committee Report, in a neighbouring town the newly militant Travancore Labour Association, controlled now by the CSP, was addressing a 'largely attended meeting' of mostly Ezhava labourers, urging them to 'get organized' (The Hindu, 2 March 1935).

6 In comparison with Travancore, lower caste movements in Malabar were less dynamic, and did not possess the independent initiative to develop in more radical directions. The reason for this is that Malabar, under 'direct' rule, did not undergo the kind of modernization and commercialization that Travancore did under 'indirect 


\section{Notes}

rule', and thus its caste hierarchy was disturbed in an entirely different fashion. Whereas in Travancore the 'middle class' among the low castes led a movement against the caste system, in Malabar the initiative came 'from above'.

7 Arguably the Congress Party was both a party and movement, but the share in local power and the adoption of office created a stronger organizational edifice than it possessed before.

8 I part company with Joshi (1992) and Chandra's (1986) characterization of the Congress Party as a truly mass party, as the subsequent discussion shows. Its implication for my argument is also that I do not give the Congress Party any essential character, class or otherwise, and argue instead that its shifting formation over time was anchored in local structures and events on the one hand, and larger economic and political shifts under British rule on the other.

9 Tanika Sarkar (1987) suggests that this is 'obvious' to most historians of India, but in fact there is no clear explanation for why Congress nationalism should have inherently suppressed popular radicalism. Why, for example, did popular radicalism not present a much stronger challenge to Congress policy?

10 The reasons for Gandhi's enduring influence, itself unlikely to be monocausal, remain to be satisfactorily explored. Why and how did Gandhi succeed in imposing his vision, philosophy and political platform on the complex social conditions of colonial India? Indeed, to what extent Gandhian philosophy actually percolated to the bottom rungs of society is itself a question that scholars are just beginning to explore (Amin 1988). Nevertheless, Gandhi was able to assert his leadership and dominance even in the face of challenges from other leaders such as Subhash Chandra Bose. Bose (a member of the Congress Socialist Party) won the Presidency of the AICC in 1937, but had to step down when Gandhi threatened to resign. Many leaders on the left refused to support Bose at that moment, fearing the collapse of the nationalist movement.

11 Sarkar (1976: 116) has rightly contested R.P. Dutt's criticism of Gandhi as 'This Jonah of revolution, the general of unbroken disasters ... the mascot of the bourgeoisie ... [who sought] ... to find the means in the midst of a formidable revolutionary wave to maintain leadership of the mass movement', by pointing out that Gandhian ideology and methods also surely had a crucial role to play in the making of 'this formidable revolutionary wave'. See Dutt (1940: 323).

12 Gandhi's ideas would not be of such central interest if it were not for the fact that they came to be organizationally embodied in the Congress Party. After all, there is no good reason why Gandhi's influence should have predominated had a groundswell of popular insurgency and a leadership willing to deploy it towards a challenge to Congress moderation existed. Although Jawaharlal Nehru and Subhash Chandra Bose, among many other Congress leaders, were resistant to Gandhi's ideas about nonviolence and his class quietism, they never mustered enough support - indeed never put up a sufficient challenge - to undermine Gandhi's influence.

13 There are no comparative works on the regional dominant castes and classes to my knowledge. The comparative questions about the particularly weak political response of the landlords in Kerala compared with that found in Bihar or the United Provinces deserves greater attention. It is simply taken for granted that they were different - but how and why remains to be adequately answered and may provide important clues about variations in political patterns between the states.

14 While across British India, Congress Party hegemony was built on a base among rich or 'dominant' peasants who had strong anti-colonial grievances and viewed the Congress Party as a 'vehicle for their rising political aspirations' (Low 1977), the Congress Party in Kerala was not 'captured' by any such class. Two regions where the nationalist movement had the longest history, and where the Congress Party was the most embedded, were the United Provinces and Bihar in the north-eastern part of India. In these two regions the class support of the Congress Party lay among the 
commercial classes, traders, merchants and small landlords or notables (Henningham 1982; Hauser 1961). The anti-colonial campaigns of the Congress Party resonated with this strata, for the burden of colonial taxes rested most strongly among small landowners and tenants, and commercial classes who were disadvantaged by the sale of foreign cloth. Comparative evidence shows that the Congress Party embedded itself most firmly where taxes were punitively high (Hardiman 1981; Bose 1986). In comparison, the dominant classes in Kerala did not 'capture' the nationalist movement.

15 The Montague-Chelmsford reforms of 1919 allowed for greater representations of Indians in various bodies of the government, however, with limited franchise and ultimate control exercised by the Governor-General.

16 The movement for Responsible Government in Travancore was a broad, democratic attempt involving several organizations to replace monarchical rule with representative rule.

17 In contrast to a vacillating TSC, beholden to Gandhi's advice (for example, postponing civil disobedience 'indefinitely' at Gandhi's request (Indian Office Library and Records, FR 2/39, 5/39, 6/39), CSP leaders were consistently more militant in their demands for Responsible Government.

18 This is an excerpt taken from an interview with Gandhi in 1934.

Question: 'Could we not start small battles on local and specific issues against capitalism in the villages and use them as a means of strengthening the people or bringing about a sense of co-operation among them, in preference to the khadi method? When we have a choice between the two what should we prefer? If we have to sacrifice all the work that we have built up in the villages in connection with khadi while fighting against the money-lender or the landed proprietor for, say, a reduction in the rate of interest or increase in the share of agricultural produce, then what shall we do - provided the latter is more liable to evoke selfconfidence among the villagers than the khadi method of organization?'

Answer: 'It is a big proviso you have added at the end of the question. I cannot say if fights on local and specific issues against capitalists are more likely to generate the kind of determination and courage needed in a non-violent campaign ... As a practical man, claiming to be an expert in non-violent methods, I should advise you not to go in for that type of work in order to train the masses in selfconsciousness and attainment of power. We are fighting for swaraj in non-violent way. If many workers in different parts of India engage in local battles of the sort you describe, then in times of necessity, the people all over India will not be able to make common cause in a fight for swaraj'.

19 In its manifesto, published in 1936, the Bihar Provincial Kisan Sabha stated that poverty and misery of the tenants was a direct function of the nature of land tenure, the revenue and credit system and the 'merciless exploitation of imperialism', quoted in Damodaran (1992: 103).

20 Sahajanand eventually drew closer to the Forward Bloc (a party founded by Subhash Chandra Bose), in search of a consistent anti-imperialist party. He felt that the Sabha was in need of a block or platform at this particular historical moment, a 'golden opportunity which had presented itself to us ... [one which] ... future generations will rightly curse us for losing' quoted in Das (1983: 167).

21 Telengana is now the state of Andhra Pradesh. During the British era it was part of the Hyderabad state, ruled by the Nizam; the other two regions were Marathwada (six districts), now part of Maharashtra, and Karnataka (two districts), now part of the state of Karnataka.

22 Peoples' Age VI, (3 August 1947: 16) cited in Overstreet and Windmiller 1959: 263. 


\section{Structure, practices and weak left hegemony in Bengal, 1925-47}

1 On 20 March 1929, the British government arrested thirty-two people including communists, leaders of other left parties, trade unionists and peasant leaders. Among them were the British communists (members of the CPGB) Phillip Spratt and Ben Bradley, as well as top CPI leaders Muzaffar Ahmed, S.A. Dange and S.V. Ghate. Most of them were sentenced to ten to twelve years' imprisonment but pressure from the British Trade Union Congress is said to have been behind the reduction in their sentences to approximately one year (Meerut (India) 1991: xvii).

2 The terms of the compromise were: (1) all levies except that on preparing the winnowing floor should be abolished; (2) reduction of rates for preparation of the winnowing floor; (3) hay should be shared equally between the bhagchasis and jotedars; (4) jotedars should not evict the bhagchasis without some form of arbitration.

3 However, the Bengal case also shows that the lack of involvement of the Congress Party in lower caste movements does not necessarily mean that they would develop in radical fashion. The latter possibility instead depended on (1) the nature of leadership of the caste movements, and (2) the class composition of the caste associations. This observation does not change my substantive theory that in Travancore and Cochin the absence of a formal and well-entrenched Congress Party allowed the already dynamic and potentially radical movements to develop autonomously without risk of compromise.

4 Interview with Abani Lahiri, in Postwar Revolt of the Rural Poor, ed. Das Gupta 1992.

5 The legislative elections in 1937 resulted in victory for the Congress Party in Bengal. This led to increased demands for the release of political prisoners, among whom were large numbers of communists.

6 This evidence calls into question the claims made by Guha (1997) that the left leadership failed because it could not speak the language of the masses.

\section{Insurgent and electoral logics in policy regimes: Kerala and Bengal compared, 1947 to the present}

1 It must be stated at the outset that Kerala and Bengal, by virtue of having left party rule, and a higher degree of reform of land inequality than undertaken in any other part of India, are in that respect fairly similar. The analytical contrast should not occlude this point; instead, the purpose is to trace the specificity of Kerala's pathway, arguing of course, that for reasons of their own making as well as not of their choosing, the communists were able to institutionalize deeper reforms than elsewhere in India (and Bengal).

2 This theory is at odds with the theory of 'social capital' constituting the primary basis for state capacity. The concept of social capital emphasizes relations of trust between different social actors and the compromises that characterize building networks of trust. It is clear that at times these networks are more important than oppositional movements (see Heller 1999 on the uses of social capital in building Kerala's post1980s economy). Arguably the People's Plan is an attempt to build social capital. But this argument must be historicized. Kerala's policies of entitlement and welfare would not have been possible without the insurgency of lower castes and working classes, and in the future the maintenance of the state's commitment to deep structural transformation will not be possible without movements from below. This argument risks being elided in the current theoretical enthralment with social capital.

3 In 1964 ongoing debates within the CPI over the question of forming alliances with the 'progressive' section of the national bourgeosie represented within the Congress Party, ended up splitting the party. The 'left' CPI called itself the CPI (Marxist) or CPM, 
while the 'centre-right' retained the title of CPI. A third, ultra-left faction which rejected the electoral path altogether called itself the CPM-L (Marxist-Leninist).

4 I am grateful to Professor K.Gopalankutty for this citation.

5 Franda 1971: 163-64.

6 Times of India, 19 August 2002.

7 Like Kohli, Evans reduces the state to left parties, thus failing to distinguish between the institutions of the state, multiple parties and inter-party competition, and the parliamentary and extra-parliamentary roles of the left. In Kerala, these are particularly distinctive, unlike in Bengal where the CPM dominates the state and political competition. 


\section{Bibliography}

Abbott, A. (2001) Time Matters: On Theory and Method, Chicago: University of Chicago Press.

- (1992) 'From Causes to Events: Notes on Narrative Positivism', Sociological Methods and Research, 20(4): 428-55.

- (1990) 'Conceptions of Time and Events in Social Science Methods: Causal and Narrative Approaches', Historical Methods, 23(4): 140-50.

Ahmad, M. (1959) Communist Party of India: Years of Formation, 1921-1933, Calcutta: National Book Agency Private.

AICC files (1930-47) All India Congress Committee Papers, New Delhi: Nehru Memorial Museum and Library, New Delhi.

AIKS (All India Kisan Sabha) (1944), Organizational Reportage No. 4 of 1944-1945, New Delhi.

Aiyer, U.S.P. (1998) Progress of Travancore Under H.H. Sree Moolam Tirunal, Department of Cultural Publications: Government of Kerala.

Alexander, K.C. (1989) 'Caste Mobilization and Class Consciousness: The Emergence of Agrarian Movements in Kerala and Tamil Nadu', in F. Frankel and M.S.A. Rao (eds) Dominance and State Power in Modern India, Vol. I, Oxford: Oxford University Press. Ambedkar, B.R. (1968) Annihilation of Caste: A Reply to Mahatma Gandhi, Jullunder City: Bheem Patrika Publications.

Amin, S. (1988) 'Gandhi as Mahatma', in R. Guha and G. Spivak (eds) Selected Subaltern Studies, Oxford: Oxford University Press.

Aminzade, R. (1992) 'Historical Sociology and Time', Sociological Methods and Research, 20: 456-80.

Arun, S. and Arun, T.G. (2001) 'Gender Issues in Social Security Policy of Developing Countries: Lessons from Kerala Experience', International Social Security Review, 54: 93-110.

Baker, C.J. (1972) The Politics of South India, 1920-1937, Cambridge: Cambridge University Press.

Balaram, N.E. (1973) Keralathile Kammyunistu Prasthanam (The Communist Movement in Kerala), Vol. I, Trivandrum.

Bandyopadhyaya, S. (1990) Caste, Politics and the Raj: Bengal, 1872-1937, Delhi: K.P. Bagchi and Co.

- (1997) Caste, Politics and Identity in Colonial India: The Namasudras of Bengal, 1872-1947, Surrey, UK: Curzon.

Bardhan, P. (1984) The Political Economy of Development in India, Oxford: Blackwell. 
Bastin, J. and Benda, H. (1977) A History of Modern Southeast Asia, Sydney: Prentice Hall of Australia.

Basu, S. (1982) Politics of Violence. A Case Study of West Bengal, Calcutta: Minerva Associates.

Bayly, C.A. (1988) Indian Society and the Making of the British Empire, Cambridge: Cambridge University Press.

Beinin, J. and Lockman, Z. (1987) Workers on the Nile: Nationalism, Communism, Islam, and the Egyptian Working Class, 1882-1954, Princeton, NJ: Princeton University Press.

Bernstein, E. (1961) Evolutionary Socialism, New York: Schocken.

Beteille, A. (1969) Castes Old and New: Essays on Social Structure and Social Stratification, Bombay, New York: Asia Publishing House.

Bhagat, K.P. (1962) The Kerala Mid-term Elections of 1960; the Communist Party's Conquest of New Positions, Bombay: Popular Book Depot.

Bhat, P.N.M. (2001) 'Maternal Mortality Rate in India: An Update', Online. Available http://www.iussp.org/Brazil2001/s10/S16_01_Bhat.pdf

Bhattacharyya, J. (1978) 'An Examination of Leadership Entry in Bengal Peasant Revolts, 1937-1947', Journal of Asian Studies, 37(4): 611-35.

Biju, M.R. (1995) 'LDF's Repeat Performance, Kerala's Local Body Elections', Economic and Political Weekly, 30(41-42): 2550-52.

Bose, S. (1981) “ "Industrial Unrest” and Growth of Labour Unions in Bengal', Economic and Political Weekly, 16: 849-60.

Bose, S. (1986) Agrarian Bengal: Economy, Social Structure and Politics, 1919-1949, Cambridge: Cambridge University Press.

Bouton, M. (1985) Agrarian Radicalism in South India, Princeton, NJ: Princeton University Press.

Broomfield, J.H. (1968) Elite Conflict in a Plural Society: Twentieth Century Bengal, Berkeley: University of California Press.

Buchanan, F. (1807) A Journey From Madras Through the Countries of Mysore, Canara and Malabar Vol. 1, London: T. Cadell and W. Davies.

Burawoy, M. (1990) 'Marxism As Science: Historical Challenges and Theoretical Growth', American Sociological Review, 55(6): 775-93.

Caldwell, J.C. (1986) 'Routes to Low Mortality in Poor Countries', Population and Development Review 12(2).

Casinader, R. (1995) 'Making Kerala Model More Intelligible, Comparisons with Sri Lankan Experience', Economic and Political Weekly, 30(48): 3085-92.

Castles, F. (1978) The Social Democratic Image of Society, London: Routledge and Kegan Paul.

Census of India 1931 (1933), Part 1.

- (1961) Vol. XVI, Bengal and Sikkim, Part I-A, book (ii).

- (1991) Series 12, Kerala.

Census of India 2001, Online. Available (http://www.censusindia.net/results/ 2001census_data_index.html)

Census of Travancore (1931) Travancore: Superintendent Government Press.

Centre for Development Studies (1975) Poverty, Unemployment and Development Policy: A Case Study of Selected Issues with Reference to Kerala, Geneva: United Nations.

Chakrabarty, B. (1990) Subhas Chandra Bose and Middle Class Radicalism, London: I.B. Taurus \& Co. 
Chakrabarty, D. (2000) Rethinking Working-Class History: Bengal, 1890 to 1940, Princeton, NJ: Princeton University Press.

Chakravarti, A. (2001) Social Power and Everyday Class Relations: Agrarian Transformation in North Bihar, Thousand Oaks, CA: Sage Publications.

Chandavarkar, R. (1998) Imperial Power and Popular Politics: Class, Resistance, and the State in India, c1850-1950, Cambridge: Cambridge University Press.

Chandra, B. (1986) 'Struggle for the Ideological Transformation of the National Congress in the 1930s', Social Scientist, 14(9): 18-39.

Chandramohan, P. (1987) 'Popular Culture and Socio-Religious Reform: Narayana Guru and the Ezhavas of Travancore', Studies in History, 3(1): 57-74.

Chasin, B.H. and Franke, R.W. (1991) 'The Kerala Difference' (letter to the editor), The New York Review of Books, 24 October, 38(17): 72.

Chatterjee, P. (1984) Bengal: 1920-1947, Calcutta: K.P. Bagchi and Co.

_ (1986) 'The Colonial State and Peasant Resistance in Bengal, 1920-1947', Past and Present, 110: 169-203.

- (1993) The Nation and Its Fragments: Colonial and Postcolonial Histories, Princeton, NJ: Princeton University Press.

Chaudhuri, B.B. (1979) 'Agrarian Movements in Bengal and Bihar, 1919-1939', in Desai, A.R. (ed.) Peasant Struggles in India, Oxford: Oxford University Press.

Chhibber, P. (1999) Democracy without Associations: Transformation of the Party System and Social Cleavages in India, Ann Arbor: University of Michigan Press.

Chhibber, V. (2003) Locked in Place: State-Building and Late Industrialization in India, Princeton, NJ: Princeton University Press.

Comaroff, J. and Comaroff, J. (1991) Of Revelation and Revolution, Chicago: University of Chicago Press.

Cooper, A. (1988) Sharecropping and Sharecroppers' Struggles in Bengal, 1930-1950, Delhi: K.P. Bagchi.

Cox, J. (2002) Imperial Fault Lines. Christianity and Colonial Power in India, 1818-1940, Stanford: Stanford University Press.

Crown Residential Records (CRR) (1930-47, London: India Office Library.

Daalder, H. and Mair, P. (1983) Western European Party Systems: Continuity and Change, Sage Publications.

Damodaran, K. (1977) 'Memoir of an Indian Communist', interview with Tariq Ali, New Left Review.

Damodaran, V. (1992) Broken Promises: Popular Protest, Indian Nationalism and the Congress Party in Bihar, 1935 to 1946, Oxford: Oxford University Press.

Das, A. (1983) Agrarian Unrest and Socio-Economic Change in Bihar, 1900-1980, New Delhi: Manohar.

Dasgupta, B. (1984) 'Sharecropping in West Bengal: From Independence to Operation Barga', Economics and Political Weekly, XIX(26): A-85-96.

Das Gupta, R. (1992) Economy, Society, and Politics in Bengal: Jalpaiguri, 1869-1947, Delhi, New York: Oxford University Press.

De, A. (1980) 'Formation of Communist Party in Faridpur: A Case Study of Communist Movement in a Bengal District', in K.N. Panikkar (ed.) National and Left Movements in India, New Delhi: Vikas.

Desai, Manali. (2001) 'Party Formation, Political Power, and the Capacity for Reform: Comparing Left Parties in Kerala and West Bengal, India', Social Forces, 80(1): 37-60. 
- (2002) 'The Relative Autonomy of Party Practices: A Counterfactual Analysis of Left Party Ascendancy in Kerala, India, 1934 to 1940', American Journal of Sociology, 108: 3.

Dev, S.M. (1994) Social Security in the Unorganized Sector: Lessons from the Experiences of Kerala and Tamil Nadu, Bombay: Indira Gandhi Institute of Development Research.

Dhanagare, D.N. (1983) Peasant Movements in India, 1920-1950, Oxford: Oxford University Press.

Dirks, N. (1989) 'The Invention of Caste: Civil Society in Colonial India', Social Analysis, 25(2): 42-52.

Dogan, M. (1967) 'Political Cleavage and Social Stratification in France and Italy', in S. Lipset and S. Rokkan (eds) Party Systems and Voter Alignments, Glencoe: The Free Press.

Dreze, J. and Sen, A. (1991) 'Public Action for Social Security', in E. Ahmed (ed.) Social Security in Developing Countries, Oxford: Clarendon Press.

— (1995) India: Economic Development and Social Opportunity, Oxford: Oxford University Press.

— (1996) Indian Development: Selected Regional Perspectives, Delhi: Oxford University Press.

Duiker, W. (1981) The Communist Road to Power in Vietnam, Boulder, CO: Westview Press.

Dutt, R.P. (1940) India Today, London: Victor Gollancz.

Echeverri-Gent, J. (1992) 'Public Participation and Poverty Alleviation: The Experience of Reform Communists in India's West Bengal', World Development, 20(10): 1401-23.

Elster, J. (1978) Logic and Society: Contradictions and Possible Worlds, New York: Wiley.

Esping-Andersen, G. (1985) Politics Against Markets, Princeton, NJ: Princeton University Press.

— (1990) 'Single Party Dominance in Sweden', in T.J. Pempel (ed.) Uncommon Democracies, Ithaca, NY: Cornell University Press.

Evans, P. (1995) Embedded Autonomy, Princeton, NJ: Princeton University Press.

Evans, P., Rueschemeyer, D. and Skocpol, T. (1985) Bringing the State Back In, Cambridge: Cambridge University Press.

Fisher, M. (1991) Indirect Rule in India: Residents and the Residency System, 1764-1858, Delhi: Oxford University Press.

Forbes, J. (1813) Oriental Memoirs, Vol. 1, London: White, Cochrane and Co.

Franda, M. (1971) 'Radical Politics in West Bengal', in P. Brass and M. Franda (eds) Radical Politics in South Asia, Boston, MA: MIT Press.

Franke, R.W. and Chasin, B. (1989) Kerala: Radical Reform as Development in an Indian State, San Francisco: Institute for Food and Development Policy.

_ (1991a) 'Kerala State, India: Radical Reform as Development', Monthly Review, $42(8)$.

_ (1991b) 'Reply to K.T. Ram Mohan' (on radical reform in Kerala), Monthly Review, 43(7): 32.

Frankel, F. (1978) India's Political Economy, 1947-1977: The Gradual Revolution, Princeton, NJ: Princeton University Press.

Frankel, F. and Rao, M.S.A. (1989-90) Dominance and State Power in India: Decline of a Social Order Vols. I and II, Delhi, New York: Oxford University Press.

Fuller, C.J. (1976) The Nayars Today, Cambridge: Cambridge University Press.

Fung, A. and Wright, E.O. (2001) 'Deepening Democracy: Innovations in Empowered Participatory Governance', Politics and Society, 29(1): 5-8. 
Gallagher, J. (1973) 'Congress in Decline: Bengal, 1930-1939', Modern Asian Studies, 7(3): 589-645.

Ganesh, K.N. (1990) 'The Process of State Formation in Travancore', Studies in History, 6(1): $15-33$.

Gazdar, H. (1992) Rural Poverty, Public Policy and Social Change: Some Findings From Surveys of Six Villages, Helinski: WIDER.

Gazdar, H. and Sengupta, S. (1997) 'Agrarian Politics and Rural Development in West Bengal', in J. Dreze and A. Sen (eds) Indian Development: Selected Regional Perspectives, Oxford: Oxford University Press.

George, J. (1992) Unionization and Politicization of Peasants and Agricultural Laborers in India: With Special Reference to Kerala, New Delhi: Commonwealth Publishers.

George, K.K. (1993) Limits to Kerala Model of Development, Thiruvananthapuram: Centre for Development Studies.

(1998) 'Historical Roots of Kerala Model and its Present Crisis', Bulletin of Concerned Asian Scholars, 30(4): 35-40.

Ghose, B.C. and Sinha, B. (1948) Planning for West Bengal, London: Oxford University Press.

Ghosh, A. (1981) Peaceful Transition to Power: A Study of Marxist Political Strategies in West Bengal, 1967-1977, Calcutta: Firma KLM Pvt.

Giddens, A. (1976) New Rules of Sociological Method, London: Hutchinson.

Gokhale, J.B. (1989) 'The Evolution of a Counter Ideology: Dalit Consciousness in Maharashtra', in F. Franke and M.S.A. Rao (eds) Dominance and State Power in Modern India, Vol. I, Oxford: Oxford University Press.

Goldstone, J. (ed.) (2003) States, Parties and Social Movements, Cambridge: Cambridge University Press.

Gopalan, A.K. (1959) Kerala: Past and Present, London: Lawrence and Wishart.

- (1973) In the Cause of the People: Reminiscences, Madras: Orient Longman.

Gopalankutty, K. (1978) 'The Rise and Growth of the Communist Party in Malabar, 1934-1947', Unpublished M. Phil. thesis, Centre for Historical Studies, School of Social Sciences, Jawaharlal Nehru University, New Delhi.

_ (1989a) 'The Task of Transforming the Congress: Malabar, 1934-1940', Studies in History, 5(2): 177-94.

— (1989b) 'Mobilization against the State and Not against the Landlords: The Civil Disobedience Movement in Malabar', Indian Economic and Social History Review, 26(4): 460-80.

- (1993) 'National Movement in Kerala', Malabar Mahotsav.

Gordon, L. (1974) Bengal: The Nationalist Movement 1876-1940, New York: Columbia University Press.

Gough, K. (1979) 'Indian Peasant Uprisings', in A.R. Desai (ed.) Peasant Struggles in India, Oxford: Oxford University Press.

Gould, R. (1995) Insurgent Identities: Class, Community, and Protest in Paris from 1848 to the Commune, Chicago: Chicago University Press.

Government of India (2001) Sample Registration Census.

Government of Travancore (1937) Travancore Administration Report, 1936-1937, Trivandrum: Superintendent Press.

Government of West Bengal (1962) Statistical Abstract, Alipore: West Bengal Government Press.

Govindan, K.C. (1986) Memoirs of an Early Trade Unionist, Trivandrum: Centre for Development Studies. 
Gramsci, A. (1957) The Modern Prince and Other Writings, New York: International Publishers.

[1929-35] (1971) Selections from the Prison Notebooks. Ed. Q. Hoare and G. Smith, New York: International Publishers.

Griffin, L. (1993) 'Narrative, Event-Structure Analysis, and Causal Interpretation in Historical Sociology', American Journal of Sociology, 98: 1094-133.

Guha, R. (1996) A Rule of Property for Bengal, Durham and London: Duke University Press.

- (1997) Dominance Without Hegemony: History and Power in Colonial India, Cambridge, MA: Harvard University Press.

_ (1998) 'The Prose of Counterinsurgency', in R. Guha and G. Spivak G. (eds) Selected Subaltern Studies, Oxford: Oxford University Press.

Hansen, T.B. and Stepputat, F. (eds) (2002) States of Imagination, Durham: Duke University Press.

Hardiman, D, (1981) Peasant Nationalists of Gujarat: Kheda District, 1917-1934, Delhi: Oxford University Press.

(1985) 'Congress Organization in Gujarat in the 1920s and 1930s', in D.N. Panigrahi

(ed.) Economy, Society \& Politics in Modern India, New Delhi: Vikas Publishing House Pvt.

_ (1989) (ed.) Peasant Resistance in India, 1858-1914, Delhi: Oxford University Press.

Harmel, R. and Robertson, J.D. (1984) 'Formation and Success of New Parties: A CrossNational Analysis', International Political Science Review, 6: 501-23.

Hauser, W. (1961) The Bihar Provincial Kisan Sabha, 1929-1942: A Study of an Indian Peasant Movement, unpublished dissertation, University of Chicago.

Haydu, J. (1998) 'Making Use of the Past: Time Periods as Cases to Compare and as Sequences of Problem Solving', American Journal of Sociology, 104(2): 339-71.

Heller, P. (1995) 'From Class Struggle to Class Compromise: Redistribution and Growth in a South Indian State', Journal of Development Studies, 31(5): 645-73.

— (1999) The Labor of Development, Ithaca, NY: Cornell University Press.

— (2000) 'Degrees of Democracy: Some Comparative Lessons from India', World Politics, 50(4): 484-519.

(2001) 'Moving the State: The Politics of Deliberative Democracy in Kerala, Porto Allegre and South Africa', Politics and Society, 29(1): 131-63.

Henningham, S. (1982) Peasant Movements in Colonial India: North Bihar, 1917-1942, Canberra: Australian National University Press.

Herring, R.J. (1983) Land to the Tiller: The Political Economy of Agrarian Reform in South Asia, New Haven: Yale University Press.

— (1988) 'Stealing Congress's Thunder: The Rise to Power of a Communist Movement in South India', in K. Lawson and P. Merkl (eds) When Parties Fail: Emerging Alternative Organizations, Princeton, NJ: Princeton University Press.

(1991) 'From Structural Conflict to Agrarian Stalemate: Agrarian Reforms in South India', Journal of Asian and African Studies, XXVI(3-4).

Hindu, The (1934-1940).

Huber, E., Rueschemeyer, D. and Stephens, J. (1997) 'The Paradoxes of Contemporary Democracy: Formal, Participatory, and Substantive Dimensions', Comparative Politics, 29(3): 323-42. 
India Office Library and Records Files of the Public and Judicial Department (L/P and J), Fortnightly Reports of Governors, Chief Commissioners and Chief Secretaries, 1937-48 (L/P and J/197-210), London.

Innes, C. and Evans, F. (1951) Malabar District Gazetteers, Madras: Government Press. International Confederation of Free Trade Unions (1959) Communist Ministry and Trade Unions in Kerala: Impact of the Communist Ministry on the Trade Union Movement in Kerala, New Delhi: International Confederation of Free Trade Unions, Asian Regional Organization.

Isaac, T.M. (1983) 'The Emergence of Radical Working Class Movement in Alleppey, 1922-1938', Working Paper 175, Trivandrum: Centre for Development Studies.

_ (1984) 'Sree Narayana Movement in Travancore, 1888-1939: Social Basis and Ideological Reproduction', Working Paper 214, Trivandrum: Centre for Developing Studies.

Isaac, T.M. and Franke, R. (2000) Local Democracy and Development, New Delhi: Leftword Books.

Isaac, T.M. and Kumar, S.M. (1991) 'Kerala Elections, 1991: Lessons and Non-Lessons', Economic and Political Weekly, 23 November.

Isaac, T.M. and Tharakan, M. (1995) 'Kerala: Towards a New Agenda', Economic and Political Weekly, 30: 1993-2004.

Isaac, T.M., Franke, R. and Parameswaran, M.P. (1997) 'From Anti-Feudalism to Sustainable Development: The Kerala People Science Movement', Bulletin of Concerned Asian Scholars, 29(3): 34-44.

Iyengar, S.K. (1931) Economic Investigations in the Hyderabad State, 1929-1930. Vol. I. General Survey, Hyderabad: Government Central Press.

- (1951) Rural Economic Enquiries in the Hyderabad State, 1949-51, Hyderabad: Government Press.

Jeffrey, R. (1976) The Decline of Nayar Dominance, New York: Holmes \& Meier Publications.

_ (1978) (ed.) People, Princes and Paramount Power, Oxford: Oxford University Press.

_ (1979) 'Peasant Movements and the Communist Party in Kerala, 1937-1960', in D.B. Miller (ed.) Peasants and Politics: Grass Roots Reaction to Change in Asia, New York: Edward Arnold.

— (1981) 'India's Working Class Revolt: Punnapra Vayalar and the Communist Conspiracy of 1946', Indian Economic and Social History Review, XVII(2): 97-122.

_ (1984) 'Destroy Capitalism! Growing Solidarity of Alleppey's Coir Workers, 1930-1940', Economic and Political Weekly, XIX(29).

(1992) Politics, Women and Well Being: How Kerala Became a 'Model', London: Macmillan Press.

Jenkins, R. (1999) Democratic Politics and Economic Reform in India, Cambridge: Cambridge University Press.

Jeromi, P.D. (2004) 'What Ails Kerala's Economy: A Sectoral Explanation', Economic and Political Weekly, 19 April.

Jessop, B. (1990) State Theory: Putting the Capitalist State in Its Place, Philadelphia: Pennsylvania State University Press.

Johnson, C. (1962) Peasant Nationalism and Communist Power, Stanford, CA: Stanford University Press.

Jose, A.V. (1980) 'Agricultural Labor in Kerala: A Historical cum Statistical Analysis', $\mathrm{Ph} . \mathrm{D}$. thesis, Centre for Developing Studies, Trivandrum, Kerala. 
(1984) 'Poverty and Inequality - The Case of Kerala', in A.R. Khan and E. Lee (eds) Poverty in South Asia, Bangkok: ILO.

Joshi, S. (1992) Struggle for Hegemony in India, 1920-1947: The Colonial State, the Left and the National Movement. Vol. I, New Delhi: Sage Publications.

Kabir, M. (1997) 'Peasants and Politics in Malabar', Economic and Political Weekly, 32(18): 942-50.

Kannan, K.P. (1988) Of Rural Proletarian Struggles: Mobilization and Organization of Rural Workers in South-West India, Delhi: Oxford University Press.

— (1995) 'Public Intervention and Poverty Alleviation: A Study of the Declining Incidence of Rural Poverty in Kerala, India', Development and Change, 26: 701-27.

- (2005) 'Kerala's Turnaround in Growth: Role of Social Development, Remittances and Reform', Economic and Political Weekly, 5 February.

Karat, P. (1977) 'Organized Struggles of Malabar Peasantry, 1934-40', Social Scientist, 5(8): 3-17.

Karnik, V.B. (1957) Indian Communist Party Documents, 1930-1956, Bombay, India: Democratic Research Service.

Kautsky, K. (1971) The Class Struggle, New York: W.W. Norton.

Kaviraj, S. (1997) 'A Critique of the Passive Revolution', in P. Chatterjee (ed.) State and Politics in India, Oxford: Oxford University Press.

Kawashima, K. (1998) Missionaries and a Hindu State, Travancore 1858-1936, Delhi: Oxford University Press.

Keane, J. (ed.) (1988) Civil Society and the State: New European Perspectives, London: Verso.

Keck, M. (1992) The Workers' Party in Brazil, New Haven, CT: Yale University Press.

King, G., Keohane, R. and Verba, S. (1994) Designing Social Inquiry: Scientific Inference in Qualitative Research, Princeton, NJ: Princeton University Press.

Kimeldorf, H. (1988) Reds or Rackets: The Making of Radical and Conservative Unions on the Waterfront, Berkeley: University of California Press.

Kitschelt, H. (1988) 'Left-Libertarian Parties: Explaining Innovation in Competitive Party Systems', World Politics, 40: 194-234.

Kiser, E. and Hechter, M. (1991) 'General Theory's Role in Comparative-Historical Sociology', American Journal of Sociology, 97: 1-30.

Kohli, Atul. (1987) The State and Poverty in India, Cambridge: Cambridge University Press.

(1989) 'From Elite Activism to Democratic Consolidation: The Rise of Reform Communism in West Bengal', in F. Frankel and M.S.A. Rao (eds) Dominance and State Power in Modern India, Vol. II, Oxford: Oxford University Press.

(2001) The Success of India's Democracy, Cambridge: Cambridge University Press.

Kolko, G. (1985) Anatomy of a War, New York: Pantheon Books.

Kooiman, D. (1977) 'Jobbers and the Emergence of Trade Unions in Bombay City', International Review of Social History, 22(3): 313-28.

- (1989) Conversion and Social Equality in India: the London Missionary Society in Southern Travancore, Delhi: Manohar Publications.

Korpi, W. (1980) 'Social Policy Strategies and Distributional Conflict in Conflict in Capitalist Democracies', West European Politics, 3(3): 296-316.

Korpi, W. and Shalev, M. (1980) 'Strikes, Power, and Politics in the Western Nations, 1900-1976', Political Power and Social Theory, 1: 301-34.

Krishna, G. (1966) 'The Development of the Indian National Congress as a Mass Organization, 1918-1923', Journal of Asian Studies, XXXV(3): 413-30. 
Krishnan, T.V. (1971) Kerala's First Communist: Life of 'Sakhavu' Krishna Pillai, New Delhi: New Age Press.

Kumar, B.G. (1982) 'Government Intervention and Levels of Living in Kerala, India', unpublished dissertation, University of Oxford.

Kumar, D. (ed.) (1982) Cambridge Economic History of India, vol. 2, Cambridge: Cambridge University Press.

Kumar, K. (1984) Peasants in Revolt: Tenants, Landlords, Congress and the Raj in Oudh, 1886-1922, New Delhi: Manohar.

Kunhi, K.V. (1993) Tenancy Legislation in Malabar 1880-1970, New Delhi: Northern Book Centre.

Kurup, K.K.N. (1988) 'Peasantry and Anti-Imperialist Struggles in Kerala', Social Scientist, 16( 9): 35-46.

Lahiri, A. (2001) Post-war revolt of the Rural Poor in India (Interview with Dasgupta, R.), Calcutta: Seagull Books.

Lekas, P. (1996) 'The Supra-class Rhetoric of Nationalism: an Introductory Iomment', East European Quarterly, 30(3): 271-83.

Lenin, V. (1933) State and Revolution, London: Martin Lawrence.

Lieten, G. (1975) 'Nature of Travancore's Economy between the Two World Wars', Journal of Kerala Studies (1): 105-23.

(2002a) 'The Human Development Puzzle in Kerala', Journal of Contemporary Asia 21(1): 47-68.

- (2002b) 'Human Development in Kerala: Structure and Agency in History', Economic and Political Weekly, 20 April.

Lindberg, A. (2001) 'Caste, Class and Gender among Cashew Workers in the Southern State of Kerala, 1930-2000', International Review of Social History, 46(2): 155-85.

Lipset, S.M. (1960) Political Man: The Social Bases of Politics, Garden City, NY: Doubleday.

Lipset, S.M. and Rokkan, S. (eds) (1967) Party Systems and Voter Alignments: CrossNational Perspectives, New York: Free Press.

Logan, W. [1887] (1951) Malabar. Vols. 1 and 2, Madras: Superintendent Government Press.

Low, D.A. (1977) Congress and the Raj, New Delhi: South Asia Books.

McAdam, D. (1982) Political Process and the Development of Black Insurgency, Chicago: University of Chicago Press.

McDonald, G. (1977) 'Unity on Trial: Congress in Bihar, 1929-1939', in D.A. Low (ed.) Congress and the Raj, New Delhi: South Asia Books, pp. 289-314.

McGuire, J. (1983) The Making of a Colonial Mind: A Quantitative Study of the Bhadralok in Calcutta, 1857-1885, Canberra: ANU Press.

Madras (Presidency) (1939) Report on Trade Disputes in the Mats and Matting Industry (RTDMMI), Madras: Superintendent Government Press.

Madras (Presidency) (1940) Malabar Tenancy Committee Report, Madras: Superintendent Government Press.

Maisel, L. and Cooper, J. (eds) (1978) Political Parties: Development and Decay, Sage Publications.

Malabar Tenancy Committee (1929) Malabar Tenancy Act, 1929, London: India Office Library and Records.

Mallick, R. (1990) 'Limits to Radical Intervention: Agricultural Taxation in West Bengal', Development and Change, 21: 147-64. 
(1993) Development Policy of a Communist Government, Cambridge: Cambridge University Press.

Mamdani, M. (1996) Citizen and Subject: Contemporary Africa and the Legacy of Colonialism, Princeton, NJ: Princeton University Press.

Manickam, S. (1977) The Social Setting of Christian Conversion in South India: The Impact of the Wesleyan Methodist Missionaries on the Trichy-Tanjore Diocese With Special Reference to the Harijan Communities of the Mass Movement Area 1820-1947, Wiesbaden: Franz Steiner.

Mann, M. (1986) The Sources of Social Power II, Cambridge: Cambridge University Press.

Manor, J. (1977) Political Change in an Indian State: Mysore, 1917-1955, Delhi: Manohar.

Mateer, Rev. S. (1871) The Land of Charity: A Descriptive Account of Travancore and its People, with Especial Reference to Missionary Labour, London: John Snow and Co.

Mathew, P.M. (2005) 'Kerala's Turnaround in Growth: A Discussion', Economic and Political Weekly, 23 July.

Mayer, A.C. (1952) Land and Society in Malabar, Bombay, New York: Oxford University Press.

Meerut (India). Sessions Court. (1991) Judgement on the Meerut Conspiracy Case, Calcutta: State Archives of West Bengal, Education Department.

Mencher, J. (1966) 'Kerala and Madras: A Comparative Study of Ecology and Social Structure', Ethnology, 52: 135-171.

Menon, D. (1994) Caste, Nationalism and Communism in South India, Cambridge: Cambridge University Press.

Menon, P. (ed.) (1970) The History of Freedom Movement in Kerala, Vols I and. II (1885-1947), Trivandrum: Government Press.

Miliband, R. (1983) Class Power and State Power, London: Verso.

Moore, B. (1966) Social Origins of Dictatorship and Democracy, Boston, MA: Beacon Press.

Murthy, K.G.K. and Rao, G. (1968) Political Preferences in Kerala: An Electoral Analysis of the Kerala General Elections, 1957, 1960, 1965 and 1967, New Delhi: Radha Krishna.

Nag, M. (1983) 'Impact of Social and Economic Development on Mortality: Comparative Study of Kerala and West Bengal', Economic and Political Weekly, 18: 877-900.

Nagam Aiya, V. (1906) Travancore State Manual, vol. II, Trivandrum: Travancore Government Press.

Nair, K.K. (ed.) (1975) Who is Who of Freedom Fighters in Kerala, Ernakulum: Government Press.

Namboodiripad, E.M.S. (1943) A Short History of the Peasant Movement in Kerala, Bombay: People's Publishing House.

— (1952) The National Question in Kerala, Bombay: People's Publishing House. (1957) Kerala: Problems and Possibilities, New Delhi: Communist Party of India. (1959) Twenty-Eight Months in Kerala: A Retrospect, New Delhi: People's Publishing House.

(1968) Kerala, Yesterday, Today and Tomorrow, Calcutta: National Book Agency. (1976) How I Became A Communist, Trivandrum: Chinta Publishers.

- (1984) Kerala Society and Politics: An Historical Survey, Delhi: National Book Centre.

National Archives of India (1930-47) Home Political Files. 
Nayanar, E.K. (1980) The Left Democratic Alternative, Trivandrum: Department of Public Relations, Government of Kerala.

Nossiter, T.J. (1982) Communism in Kerala, Oxford: Oxford University Press.

O'Hanlon, R. (1985) Caste, Conflict and Ideology: Mahatma Jotirao Phule and Low Caste Protest in Nineteenth Century Western India, Cambridge: Cambridge University Press.

Oddie, G. (1979) Social Protest in India: British Protestant Missionaries and Social Reforms, 1850-1900, New Delhi: Manohar.

Omvedt, G. (1976) Cultural Revolt in a Colonial Society: the Non Brahman Movement in Western India, 1873 to 1930, Bombay: Scientific Socialist Education Trust.

Oommen, T.K. (1985) From Mobilization to Radicalization: The Dynamics of Agrarian Movement in Twentieth Century Kerala, Bombay: Popular Prakashan.

Ouwekerk, L. (1994) No Elephants for the Maharaja: Social and Political Change in the Princely State of Travancore (1921-1947) ed. with an introduction by Dick Kooiman, New Delhi: Manohar.

Overstreet, G.D. and Windmiller, M. (1959) Communism in India, Berkeley: University of California Press.

Paige, J. (1975) Agrarian Revolution, New York: The Free Press.

- (1999) 'Conjuncture, Comparison, and Conditional Theory in Macrosocial Inquiry', American Journal of Sociology, 105: 781-800.

Pandey, G. (1988) 'Congress and the Nation, 1917-1947', in R. Sisson and S. Wolpert (eds) Congress and Indian Nationalism: The Pre-Independence Phase, Berkeley, CA: University of California Press:

Panebianco, A. (1988) Political Parties: Organization and Power, Cambridge: Cambridge University Press.

Panikkar, K.N. (1977) 'Land Control, Ideology and Reform: A Study of Changes in Family Organization and Marriage System in Kerala', Indian Historical Review, IV(1): 1-46.

_ (1978) 'Agrarian Legislation and Social Classes', Economic and Political Weekly, 17.

_ (1989) Against Lord and State: Religion and Peasant Uprisings in Malabar, 1836-1921, Delhi: Oxford University Press.

Panikkar, P.G.K. and Soman, C.R. (1984) Health Status of Kerala, Trivandrum: Centre for Development Studies.

Parayil, G. (2000) Kerala: The Development Experience. Reflections On Sustainability and Replicability, London, New York: Zed Books.

Patel, S.J. (1992) 'Agricultural Labourers in Modern India and Pakistan', in G. Prakash (ed.) The World of the Rural Agricultural Labourer, Oxford: Oxford University Press.

Pavier, B. (1981) The Telengana Movement, 1944 to 1951, New Delhi: Vikas Publishing House.

Pempel, T.J. (ed.) (1990) Uncommon Democracies: The One-Party Dominant Regimes, Ithaca, NY: Cornell University Press.

Pillai, K.K. (ed.) (1941) Travancore and Its Rule, Kerala: Sudharma Publishing House.

Pillai, R. (1929) Report, Travancore Banking Enquiry Committee, Trivandrum: The Government Press.

Piven, F. and Cloward, R. (1977) Poor People's Movements: Why They Succeed, How They Fail, New York: Pantheon.

Pontusson, J. (1988) Swedish Social Democracy and British Labour: Essays on the Nature and Conditions of Social Democratic Hegemony, Cornell Studies in International Affairs: Western Societies Papers.

Poulantzas, N. (1978) State, Power, Socialism. London: New Left Books. 
Prakash, B.A. (1994) Kerala's Economy: Performance, Problems and Prospects, New Delhi: Sage Publishers.

Prakash, G. (ed.) (1992) The World of the Rural Agricultural Labourer, Oxford: Oxford University Press.

Przeworski, A. (1985) Capitalism and Social Democracy, Cambridge: Cambridge University Press.

Przeworski, A., Michael E. Alvarez, José Antonio Cheibub and F. Limongi (2000) Democracy and Development: Political Institutions and Material Well-Being in the World, 1950-1990, Cambridge: Cambridge University Press.

Przeworski, A and Sprague, J. (1986) Paper Stones: A History of Electoral Socialism, Chicago: University of Chicago Press.

Putnam, R. (1993) Making Democracy Work: Civic Traditions in Modern Italy, Princeton, NJ: Princeton University Press.

Radhakrishnan, P. (1989) Peasant Struggles, Land Reforms and Social Change: Malabar, 1836-1982, New Delhi: Sage Publications.

Ragin, C. (1987) The Comparative Method: Moving Beyond Qualitative and Quantitative Strategies, Berkeley and Los Angeles: University of California Press.

Ragin, C. and Zaret, D. (1983) 'Theory and Method in Comparative Research: Two Strategies', Social Forces, 61(3): 731-754.

Rammohan, K.T. (1998) 'Kerala CPI(M): All That is Solid Melts into Air', Economic and Political Weekly, 33(40): 2579-82.

Rao, P. Kodanda (1924) Malabar Tenancy Problems, Servants of India Society.

Rasul, M.A. (1969) History of the All India Kisan Sabha, Calcutta: National Book Agency.

Ravindran, T.K. (1972) Asan and Social Revolution in Kerala, Trivandrum: Kerala Historical Society.

Ray, R. (1984) Social Conflict and Political Unrest in Bengal, 1875-1924, Oxford: Oxford University Press.

Ray, R. and Katzenstein, M (eds) (2004) Social Movements in India: Poverty, Power, and Politics, Lanham: MD: Rowman and Littlefield.

Ray, R. and Ray, R. (1971) 'Zamindars and Jotedars: A Study of Rural Politics in Bengal', Modern Asian Studies, 9(1): 81-102.

Revri, C. (1972) The Indian Trade Union Movement, New Delhi: Orient Longman.

Rodrigues, L. (1998) Rural Political Protest in Western India, Oxford: Oxford University Press.

Roosa, J. (2001) 'Passive Revolution Meets Peasant Revolution: Indian Nationalism and the Telengana Revolt', Journal of Peasant Studies, 28(4): 57-94.

Roy, S. (ed.) (1976) Communism in India: Unpublished Documents, 1935-1945, Calcutta: National Book Agency.

Rudolph, L. and Rudolph, S. (1966) 'The Political Role of India's Caste Associations', Pacific Affairs, XXXIII(1): 5-22.

- (1967) The Modernity of Tradition, Chicago: University of Chicago Press.

Rueschemeyer, D., Stephens, E. and Stephens, J. (1992) Capitalist Development and Democracy, Chicago: University of Chicago Press.

Rusch, T. (1956) 'Role of the Congress Socialist Party in the Indian National Congress, 1931-1942'. Unpublished PhD dissertation, University of Chicago.

Sanyal, H. (1979) 'Congress Movements in the Villages of East Midnapore, 1921-1931', in M. Gaborieau and A. Thorner (eds) Asie du Sud: Traditions et Changements, Paris.

Saraswati, S.S. (1940) Mera Jeevan Sangharsh (My Life Struggle), New Delhi: Granth Shilpi. 
Sarkar, S. (1976) 'The Logic of Gandhian Nationalism: Civil Disobedience and the Gandhi-Irwin Pact (1930-1931)', The Indian Historical Review, III(1): 114-46.

_ (1980) 'Popular' Movements' and 'Middle Class'Leadership in Late Colonial India: Perspectives and Problems of a 'History from Below', Calcutta: Centre for Studies in Social Sciences.

(1983) Modern India: 1885-1947, New Delhi: Macmillan India.

Sarkar, T. (1987) Bengal: 1928-1934: The Politics of Protest, Oxford: Oxford University Press.

Sasidharan, N. (1992) 'The Origins of the Communist Party of India (Marxist) in Kerala Politics: A Study of Social and Political Radicalism', unpublished Ph.D. dissertation, University of Kerala.

Sathyamurthy, T.V. (1999) Class Formation and Political Transformation in Post-colonial India, Delhi, New York: Oxford University Press.

Scott, J. (1976) The Moral Economy of the Peasant, New Haven, CT: Yale University Press.

Seidman, G. (1994) Manufacturing Militance: Workers' Movements in Brazil and South Africa, 1970-1985, Berkeley: University of California Press.

Sen, Amartya (1981) 'Public Action and the Quality of Life in Developing Countries', Oxford Bulletin of Economics and Statistics, 43(4).

— (1985) The Standard of Living, Cambridge: Cambridge University Press.

- (1990) 'More than 100 Million Women are Missing', The New York Review of Books, 20 December, 37(20): 61-6.

(1991) 'The Kerala Difference' (reply to a letter to the editor), The New York Review of Books, 24 October, 38(17): 72.

- (1995) 'Mortality as an Indicator of Economic Success and Failure', Discussion Paper DEP/66, London: London School of Economics and Political Science.

- (2000) 'Democracy: the Only Way Out of Poverty', New Perspectives Quarterly, 17(1): 28.

Sen, S. (1972) Agrarian Struggle in Bengal, 1946-47, New Delhi: People's Publishing House.

Sen, S. (1997) Working Class of India: History of Emergence and Movement, 1830-1990, Calcutta: K.P. Bagchi and Co.

Sewell, William H. (1992) 'A Theory of Structure: Duality, Agency and Transformation', American Journal of Sociology, 98(1): 1-29.

_ (1996) 'Three Temporalities: Toward a Sociology of the Event', in T. Mc Donald (ed.) The Historic Turn in the Human Sciences, Ann Arbor: University of Michigan Press.

Shariff, A. (1999) India: Human Development Report: A Profile of Indian States in the 1990s, Oxford: Oxford University Press.

Singh, B. (1944) 'Financial Development in Travancore'. Unpublished $\mathrm{PhD}$ thesis, University of Travancore.

Sinha, S. (1998) Public Health Policy and the Indian Public, Bengal 1850-1920, Calcutta: Vision Publications.

Sitaramayya, P. (1935) History of the Indian National Congress, Vol. I, Madras: The Working Committee of the Congress.

Skocpol, T. (1985) 'Bringing the State Back In: Strategies of Analysis in Current Research', in P. Evans, D. Rueschemeyer and T. Skocpol (eds) Bringing the State Back In, Cambridge: University of Cambridge Press. 
Skocpol, T. and Amenta, E. (1986) 'States and Social Policies', Annual Review of Sociology, 12: 131-57.

Somers, M. and Goldfrank, W. (1979) 'The Limits of Agronomic Determinism: A Critique of Paige's Agrarian Revolution', Comparative Studies in Society and History, 21(3): 443-58.

Srinivas, M.N. (1962) Caste in Modern India, Bombay: Asia Publishing House.

Stepan-Norris, J. and Zeitlin, M. (1996) 'Insurgency, Radicalism, and Democracy in America's Industrial Unions', Social Forces 75(1): 1-33.

— (1989) “"Who Gets the Bird?" Or, How the Communists Won Power and Trust in America's Unions: the Relative Autonomy of Intraclass Political Struggles', American Sociological Review 54(4): 503-51.

Stokes, E. (1976) 'The Return of the Peasant to South Asian History', South Asia, 6: 96-111.

Tendulkar, D.G. (ed.) (1951) Mahatma, Vol. 4, 1934-1938, Government of India.

Tharakan, P.K.M. (1984a) 'Socio-Economic Factors in Educational Development: Case of Nineteenth Century Travancore', Economic and Political Weekly, XIX(45).

_ (1984b) 'Intra-Regional Differences in Agrarian Systems and Internal Migration of Farmers from Travancore to Malabar, 1930-1950', Working Paper 194, Trivandrum: Centre for Developing Studies.

(1990) The Ernakulum District Total Literacy Programme: Report of the Evaluation, Trivandrum.

(1994) 'Search for the Roots of the Kerala 'Model' in Colonial and Pre-Colonial History: Tentative Postulations', International Congress on Kerala Studies, Trivandrum, 27-29 August.

Tharamangalam, J. (1998) 'The Perils of Social Development without Economic Growth: The Development Debacle of Kerala, India', Bulletin of Concerned Asian Scholars, 30(1).

Therborn, G. (1977) 'The Rule of Capital and the Rise of Democracy', New Left Review, 1(103): 3-41.

Thomas, P.J. and Ramakrishnan, K.C. (1940) Some South Indian Villages: A Resurvey, Madras: University of Madras.

Tilly, C., Tilly, L. and Tilly, R. (1975) The Rebellious Century, 1830-1930, London: Dent.

Törnquist, O. (1998a) 'Making Democratization Work: From Civil Society and Social Capital to Political Inclusion and Politicization - Political Reflections on Concrete Cases on Indonesia, Kerala and the Philippines', in O. Torniquist, L. Rudebeck and V. Rojas (eds) Democratization in the Third World: Concrete Cases in Comparative and Theoretical Perspective, London: Macmillan.

_ (1998b) 'Beyond Romanticism: Remarkable Popular Organizing', Bulletin of Concerned Asian Scholars, 30(4): 43-4.

Törnquist, O. and Tharakan, P.M.K. (1995) 'The Next Left? Democratization and Attempts to Renew the Radical Political Development Project. The Case of Kerala', Nordic Institute of Asian Studies, report series, no. 24. This book also appears serialized in Economic and Political Weekly, 31(28): 1847-58; 31(29): 1953-73; and 31.

Uma Devi, S. (1989) Plantation Economy of the Third World, New Delhi: Himalaya Publishing House.

Vanaik, A. (1989) The Painful Transition: Bourgeois Democracy in India, London: Verso. Varghese, T.C. (1970) Agrarian Change and Economic Consequences, Bombay: Allied Publishers Private. 
Veron, R. (2001) 'The "New" Kerala Model: Lessons for Sustainable Development', World Development, 29(4): 601-17.

VHAI (1997) Report of the Independent Commission of Health in India, New Delhi: Voluntary Health Association of India.

Washbrook, D. (1976) The Emergence of Provincial Politics: The Madras Presidency 1970-1920, Cambridge: Cambridge University Press.

_ (1989) 'Caste, Class and Dominance in Modern Tamil Nadu: Non-Brahminism, Dravidianism and Tamil Nationalism', in F. Frankel and M.S.A. Rao (eds) Dominance and State Power in Modern India, Vol. I, Oxford: Oxford University Press.

Weber, M. (1949) The Methodology of the Social Sciences, New York: The Free Press.

- (1958) The Religion of India, H. Gerth and D. Martindale (eds) Glencoe, IL: The Free Press.

- (1978) Economy and Society. Vols. I and II, Berkeley: University of California Press. Weiner, M. and Osgood, J. (1974) Electoral Politics in the Indian States: The Communist Parties of West Bengal, Delhi: Manohar Book Service.

Weir, M. and Skocpol, T. (1985) 'State Structures and the Possibilities for "Keynesian" Responses to the Great Depression in Sweden, Britain, and the United States', in P. Evans, D. Rueschemeyer and T. Skocpol (eds) Bringing the State Back In, Cambridge: Cambridge University Press.

Weiss, L. and Hobson, J. (1995) States and Economic Development: A Comparative Historical Analysis, Cambridge: Polity Press.

Wolf, E. (1969) Peasant Wars of the Twentieth Century, New York: Harper and Row.

Wood, C. (1982) 'Peasant Revolt: An Interpretation of Moplah Violence in the Nineteenth and Twentieth Centuries', in D. Hardiman (ed.) Peasant Resistance in India 1858-1914, Oxford: Oxford University Press.

(1987) The Moplah Rebellion and Its Genesis, New Delhi: People's Publishing House.

Wright, E.O. (1985) Classes, London: Verso.

Yesudas, R.N. (1977) Colonel John Munro in Travancore, Trivandrum: Kerala Historical Society.

(1980) The History of the London Missionary Society in Travancore, 1806-1908, Trivandrum: Kerala Historical Society.

Zagoria, D.S. (1971) 'The Ecology of Peasant Communism in India', American Political Science Review LXV(1): 144-160.

_ (1973) 'The Social Bases of Communism in Kerala and West Bengal', Problems of Communism 22(1).

Zeitlin, M. (1984) The Civil Wars in Chile, Princeton, NJ: Princeton University Press. 


\section{Index}

adhiars 48, 49, 116-17

adi-Dravidas (caste) 35

Agrarian Relations Bill (1957) 127

Aguris (caste) 107

Ahirs 105

All India Congress Committee 88, 93, $100,102,111$

All India Kisan Sabha 86-7, 113, 116

All Malabar Peasants' Union 113

amlas (serviceholders) 37

Andhra Mahasabha 95-6

Andhra Pradesh (Telengana): Communist Party of India strategy and party ascendancy 95-7

Andhra/Telengana 37-9

anti-colonialism $72-5$

'anti-Congress' movement 68-70

anti-poverty policy regime $5-7,19$

Anushilan Samiti 110, 112

Baidya (caste) 106

bargadari 49

Bengal: Criminal Law Amendment Act (1930) 112; Jute Workers' Association 100-1; objective conditions and potential for radicalism 47-50; Pradesh Congress Committee 102, 109, 110, 111; Pradesh Kisan Sabha 113-14; Suppression of Terrorist Outrages Act (1932) 112; Tenancy Act (1885) 104; Tenancy Amendment Act 104, 110, 111

bhadraloks 47, 48, 126; weak left hegemony 107, 108, 109-10, 114, 115 bhagchasis 103

bhagelas 38

Bhumihar (caste) 36

Bihar 36-7; Congress Socialist Party, Communist Party of India and 'intraclass' struggle 91-5
Bose, S.C. 111

bourgeois state, growth of 57-62

Brahmins 27, 66-7, 69, 106, 107

Brazil 15; Partido Trabahadores 149, 150-2

British East India Company 40

British Indian Association 104, 108, 109

British Labour Party 91, 148

caste 27; associations (sabhas) 65; Bengal 102-7; see also under specific castes

Chermuans (caste) 27

China 34, 71, 108

Christianity/missionaries $34,51-4,55,56$, 63-4, 132

Church Missionary Society 64

class: Bengal 102-7; opposition 75-9

class formation: $5,8-13,16-17,24-7$, $120,140-44$

Cochin: 'indirect rule' and uneven capitalist development 39-44

colonial state formation $72-5$

Communist League 81

Communist Party of Great Britain 89

Communist Party of India 3, 14, 35 , 142-3, 147, 150; Andhra Pradesh (Telengana) 95-7; Bengal 99-102; Bihar 91-5; Hindu-Muslim conflict 116 ; insurgent and electoral logics 121-5, 127-8, 130-3; political practices and left ascendancy 70,73 , 80-3, 86, 94-6; strategy 89-90; structure, practices and weak left hegemony 98, 104, 108, 110-17

Communist Party of India (Marxist) 35, $140,141,149,150,151$; insurgent and electoral logics 120-3, 125-6, 131, 133, 136, 138-9; 'isolationism' 99-102; welfare and left rule 4, 6, 18 
Communists 'enter' national movement $111-15$

Congress Party 140, 143, 145, 147, 149; Bengal 102-7; hegemony 71-2; insurgent and electoral logics 123, 124, 125, 137-9; political practices and left ascendancy $68-70,72-3,75-80,81$, 82, 87-8, 95-6; 'Right' vs 'Left' $108-11$

Congress-Praja Socialist Party alliance 128

Congress Socialist Party 12, 45, 140, 142-5, 147; Bihar 91-5; insurgent and electoral logics 122, 123, 124, 127; political practices and left ascendancy $68,70,73,78-83,87-9,93-4,97$; structure, practices and weak left hegemony 98-9, 102-4, 106, 108, 110, $112-15,117$; tactics in 'civil society' 83-5; working class protest and princely states $85-6$

counterfactuals $22-3,140,142$

CPI see Communist Party of India

CPM see Communist Party of India (Marxist)

CSP see Congress Socialist Party

Das, C.R. 104, 109, 110

decline and crisis: historical roots of different state capacities $135-8$

Deshmukhs 37-8

Dewan 43, 63, 69, 90

Dhakeswari Cotton Workers' Union 101

'direct' British rule 27-9

District Congress Committees 77

Dutt, R.P. 89

East India Company 39, 108

Education Bill/Act 132-3

Education Code 53, 54

electoral logics see insurgent and electoral logics

Ernakulam District Total Literacy campaign 133

Ezhavas (caste) 35, 132, 143; political practices and left ascendancy 69, 70, 76 ; state formation and social movements 52, 62, 63-4, 65, 66-7

Forward Bloc 94

Fundamental Rights Resolution 80
Gandhi, M. 9, 146; political practices and left ascendancy 70, 71, 74-5, 77, 80, $82,87,91$

Gandhi Seva Sangham 88

Gnanodaya Yogam 66

Gopalan, A.K. 89

Great Depression 24, 31, 38, 41; political practices and left ascendancy 73,79 , $85,86,91-2$

Great Indian Mutiny 57

Guru, S.N. 64, 70

hegemony $12,71-2$

Hindu-Muslim conflict and Communist Party of India 116

Hindus 33-4, 49, 70, 74, 116, 152; state formation and social movements 54 , $55,56,62,63$

historical 'turning points' 79-83

Ho Chi Minh 72, 145

Indian Association 109

Indian National Congress see Congress Party

Indian Trade Union Registered Act (1926) 72

Indigo Riots 91

'indirect rule' and uneven capitalist development in Travancore and Cochin 39-44

insurgent and electoral logics in policy regimes 119-39; contexts for leftist policy reform 123-6; decline and crisis: historical roots of different state capacities 135-8; land reforms 126-31; literacy, politics of 131-5; public health 135

'intra-class' struggle: strategic cohesion among communists 90-7

Islam/Muslims 29, 33-4, 45, 49, 77, 132; structure, practices and weak left hegemony 99, 100, 104, 105, 107, 115

Izhavas (caste) 53, 55

jagirdars 37

Jenmi Sabha 103

jenmis 37, 38; political practices and left ascendancy $68-9,76,77,83$; structure, practices and weak left hegemony 103 , 104, 106

Jogis (caste) 106 
Joshi, P.C. 96, 112

jotedars 48, 49, 125, 144

Jugantar 110, 112

Kaibartta (caste) 106

kanakkaran see kanomdars

kanom 28, 29, 30, 31, 76

kanomdars 30, 69, 103-4, 105-6

Karachi Resolution (1931) 73, 79

Karshaka Sanghams 127

Kayasthas (caste) 106, 107

Kelappan 88

Kerala: Agrarian Relations Act (1960) 129; Agricultural Workers Bill 127; Land Reforms Act 129; lower caste protests 62-4; Pradesh Congress Committee 77, 87, 88, 104, 112, 143; Shastra Sahitya Parishad 133, 134

khamar 49

Khilafat 104

Kisan Sabha 92, 93, 94, 116; Bengal Pradesh 113-14; see also All India

Kisan Sangham 127

Konar, H. 126

Krishak Praja Party 116

Kurmis (caste) 36, 105

kuzhikanam (improving lease) 31

Labour Movement in Kerala 88

Lahiri, A. 113

Land Reform Bill 127

land reforms 126-31

landlord patronage, disruption of 27-9

landlordism, intensfied and effects on agrarian relations 29-35; time, structure and rebellion in Malabar 32-5

left parties, dilemmas of in a democracy $13-16$

leftist policy reform, contexts for 123-6

Leninism 150

Liberal Democratic Party (Japan) 18

literacy: in Kerala 131-5

Logan, W. 29, 78

London Missionary Society 53, 55, 64

lower caste protests in Kerala 62-4

Macaulay, Lord 56, 57

Madhavan, T.K. 69

Mahasabha 107

Mahisyas (caste) 103, 106, 107
Malabar 32-5; District Board 88; Kidiyan Sangham 103; Tenancy Act 69, 76, 78, 104, 127; Tenancy Committee 83;

Tenants' Association 78

Marxism 3, 16, 24, 26, 91

Marxist-Leninist party 91

Mau Mau rebellion 146

Meerut Conspiracy Case 100

Mexico 15; Partido Revolucianario Institutional 8

Moplah Revolts 106, 146

Moplahs (caste) 33-4, 49

Movimento Sem Terra 151

Mughal empire 37

Munro, Colonel 40

Muslim League 73, 116

Nabasakh (caste) 106

Nair Regulation Act (1925) 77

Nair Service Society 76, 128

Nairs (caste) 27, 28, 34, 63, 65

Namasudras (caste) 106, 107

Namboodiripad, E.M.S. 89, 90, 124

Namboodiris (caste) 27, 42, 76, 78, 114-15

Nambudiri Yuvajana Sangham (Youth League) 76

Narain, J. 79

Narayana Guru, S. 66-7

nationalism 68-70; Bengal 102-7; as terrain for 'violent' strategy $86-9$

Nationalists 24

Naxalites 126

Nayar Brigades 40

Nehru, J. 73, 124

Non-cooperation-Khilafat movement 116

Operation Barga 6

Pabna Revolts 102

panchayats 103, 141

Parayas (caste) 53, 55

parliamentary democracy 3, 14, 147-9; see also strategies and tactics

Partido Revolucianario Institutional (Mexico) 8

Partido Trabahadores (Brazil) 149, 150-2

Partition of 1947 99, 116, 122

parties: relative autonomy of 16-17

party dominance vs. hegemony $17-19$

Patidars 105

Pattom Proclamation 40

peasant rebellion/radicalism 25-7 
People's Plan 137

People's Science Movement 133

Permanent Settlement 47, 108, 109

Pillai, P.K. 89

'political opportunities' for left parties 71-2

political organization 64-7

political practices and left ascendancy 68-97; class oppposition 75-9; colonial state formation and anticolonialism 72-5; Communist Party of India strategy 89-90; Congress Party hegemony and 'political opportunities' for left parties 71-2; Congress Socialist Party tactics in 'civil society' $83-5$;

Congress Socialist Party, working class protest and princely states $85-6$; historical 'turning points' 79-83; 'intra-class' struggle: strategic cohesion among communists 90-7; nationalism and 'anti-Congress' movement 68-70; nationalism as terrain for 'violent' strategy 86-9

Praja Socialist Party 123

President's Rule 125, 128

proletarianization: $12,26,50,60-2$, $114-6,140,142-3$

'proto zamindari policy 27-9

Pulayas (caste) 27, 53, 62, 64

Punnapra-Vayalar revolt 90, 123

Quit India movement 95

radicalism, potential for in Bengal 47-50

raiyati $48,49,104,114$

Ranadive, B.T. 96, 123

Rani Lakshmi Bai 40

Regulation III (1818) 112

'relative autonomy' of the political 16-17

Rent Courts system 127

Responsible Government campaign 86

Ringeltaube, W. 52-3

Roy, M.N. 99

rule and rebellion, social bases of $24-50$; Andhra/Telengana 37-9; Bihar 36-7; 'direct' British rule, 'proto' zamindari policy and landlord patronage, disruption of 27-9; 'indirect rule' and uneven capitalist development in Travancore and Cochin 39-44; landlordism, intensified and effects on agrarian relations 29-35; 'objective conditions' and potential for radicalism in Bengal 47-50; peasant rebellion/radicalism 25-7; social structure, internal comparisons in 44-6 ryotwari policy $28,39-40,57$

Sadgops (caste) 107

Sahajanand, S. 93-4

Sahas (caste) 106

Samyukta Socialist Party 123

sanskritization 34, 66

Santhal Rebellion 91

Scavengers' Union of Bengal 101

Sen, Amartya: 1-2, 8, 81, 119, 134

Shanars (caste) 62

Social Democratic Party: Samyukta 123; see also Congress Socialist Party; Sveriges Socialdemokratiska Arbertareparti

social movements see state formation and social movements

social structure, internal comparisons in 44-6

Sri Narayana Dharma Paripalan 64, 65-7, $69,70,143$

state autonomy and legacies 20-1

state formation and social movements 51-67; bourgeois state, growth of 57-62; insurgency and political organization 64-7; lower caste protests in Kerala 62-4

Stay of Eviction Proceedings Ordinance 127

structure, practices and weak left hegemony 98-118; Communists 'enter' national movement 111-15; HinduMuslim conflict and Communist Party of India 116; 'isolationism' and Communist Party of India 99-102; nationalism, caste and class: Congress Party 102-7; 'Right' vs 'Left' in Congress Party 108-11; tebhaga struggle 116-17

Sveriges Socialdemokratiska Arbertareparti (SAP) 18, 75, 148-50, 151 swadeshi 107

Swaraj Party 109-10 
Sweden see Sveriges Socialdemokratiska Arbertareparti

tebhaga struggle 116-17

Telengana revolt 96

Tiyyas (caste) 27, 35, 66-7, 77, 106, 114

Towns Improvement and Conservancy Regulation II 58

Travancore: Agricultural Laborers' Union 127; Coir Factory Workers' Union 86; 'indirect rule' and uneven capitalist development 39-44; Labour Association 86; State Congress 86

Vadakkan, Father 128

Vaikom Satyagraha 69-70 verumpattom 28, 29, 30, 31, 84, 104 Vietnam 71, 108, 145

Workers' and Peasants' Party 100-1, 102 Working Class Movement in India 88 working class protest $85-6$

Yadavs (caste) 36

Yogakshema Mahasabha 76

Youth League 76, 86

Zamindar Sabha 92

zamindari system (landlordism) 28, 36-7, $47,49,55,87,130$ 
eBooks - at www.eBookstore.tandf.co.uk

\section{A library at your fingertips!}

eBooks are electronic versions of printed books. You can store them on your PC/laptop or browse them online.

They have advantages for anyone needing rapid access to a wide variety of published, copyright information.

eBooks can help your research by enabling you to bookmark chapters, annotate text and use instant searches to find specific words or phrases. Several eBook files would fit on even a small laptop or PDA.

NEW: Save money by eSubscribing: cheap, online access to any eBook for as long as you need it.

\section{Annual subscription packages}

We now offer special low-cost bulk subscriptions to packages of eBooks in certain subject areas. These are available to libraries or to individuals.

For more information please contact webmaster.ebooks@tandf.co.uk

We're continually developing the eBook concept, so keep up to date by visiting the website. 









